Universidad Nacional de La Plata

Facultad de Ciencias Jurídicas y Sociales

Instituto de Relaciones Internacionales

LA PROTECCIÓN INTERNACIONAL DE LOS DERECHOS HUMANOS: EL CASO DEL ACOSO SEXUAL LABORAL EN ARGENTINA.

Tesis de Maestría en Relaciones Internacionales

Maestranda: Alicia Ester Serrano González

2013 
La Protección Internacional de los Derechos Humanos: caso del Acoso Sexual Laboral en Argentina

Maestranda:

Alicia Ester Serrano González

Director de Tesis:

Dr. Alberto Buela 
A mis amores, Gustavo mi esposo baluarte incondicional, mi madre René centro de mi universo; a mis hijos Rita, Ojitos, Colo, Katy, Manchi, Negrito, Falucho, Osi, Junior, Blanqui, Samsón, Dahiana, Piky, Coqui, Peper, Damita, Rosi, Pedro, Copito, Moro, Negri, Bebé, Marti, Luci, Felipe, Lunita, Clarita, Lola, Ramón, Daisy, Ethios $\mathrm{y}$ Thiago por la paz y el amor que me dan. 


\section{[LA PROTECCIÓN INTERNACIONAL DE LOS DERECHOS HUMANOS: CASO DEL ACOSO SEXUAL LABORAL EN

\section{RESUMEN}

La presente tesis de maestría en relaciones internacionales tiene por objeto el estudio del problema de la falta de positivización y de vigencia y garantía, de los derechos humanos fundamentales en el tema del acoso sexual laboral en la administración pública en Argentina respecto de otros países que evolucionaron mucho en el tema. En un contexto de transformaciones en un mundo que avanza hacia dichas garantías, ubicados antes y después de la sanción de mi autoría de la Ley provincial $\mathrm{n}^{\mathrm{o}}$ 12.764, la investigación se construyó en torno a la hipótesis de que tal problema se debe a la inexistencia de voluntad política gubernamental por la omisión del deber de debida diligencia, definida por la adhesión a una política de laissez faire propia de un constitucionalismo liberal influenciada por el realismo clásico típico de otras culturas del norte, a las que casi siempre adhirió nuestro país en la aplicación de sus políticas públicas. Los resultados de la investigación tomando como base la teoría Idealista, confrontada con el Realismo, confirmaron nuestra hipótesis dado el incumplimiento de los deberes internacionales que rezan los Tratados Internacionales incorporados a nuestra Constitución Nacional en el art. 75 inc. 22 por parte de Argentina, convirtiéndose los mismos en letra muerta, sin vigencia sociológica y confirmando que a pesar de ello, el Acoso Sexual laboral en Argentina no es un mito, es una penosa e injusta realidad. 


\section{AGRADECIMIENTOS}

La creación de este trabajo no hubiera tenido lugar sin el apoyo de varias personas. En primer lugar quisiera agradecer a mi director, el Dr. Alberto Buela, por su continua dedicación, en lo conceptual, metodológico, y por sus oportunos y bien intencionados comentarios en nuestros numerosos encuentros. Por sobre todas las cosas, le estaré por siempre agradecida por su prédica hacia la investigación. También quisiera agradecer a mis profesores de la Maestría que me enseñaron la trascendencia e importancia en la vida de cada individuo de lo que acontece a nivel internacional y en materia de Derechos Humanos, por tal motivo elegí la carrera.

En el largo y esforzado camino para felizmente concluir el presente, mi familia ha sabido comprenderme y apoyarme, no dejándome caer ni olvidar que los sueños se cumplen y que sólo debemos poner la voluntad y el amor para lograrlo. En particular, mi esposo con sus abrazos que me colmaban de la energía necesaria, mi madre quien me inculcara el sentido de la justicia y el amor por el prójimo que no se aprenden de los libros sino al ejercerlos. Sin ellos, no hubiera podido dar vida al presente o crear siquiera la Ley $\mathrm{n}^{\mathrm{o}} 12.764$ que protege a quienes son víctimas de acoso sexual laboral y que muestra su luz en mi ser. 


\section{ÍNDICE}

Resumen.............................................................. 4

Agradecimientos................................................... 5

Capítulo I Introducción, Teoría y Metodología................................ 11

1.1 Introducción ..................................................... 11

1.2 Teoría: Autoridad de los Tratados Internacionales de DH............. 12

1.2.1 Comparación entre Realismo y el Idealismo................. 16

1.2.2 Relación entre la Teoría Realista e Idealista con el acoso sexual Laboral en Argentina.................................. 17

1.3 Metodología................................................. 20

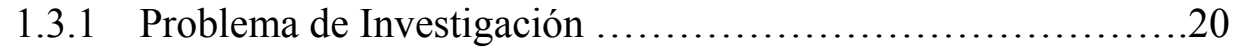

1.3.2 Nuestra hipótesis y Variables ............................. 22

1.3.3 Objetivos ..................................................... 24

1.3.4 Unidad de Análisis ....................................... 25

1.3.5 Búsqueda y selección de información ..................... 25

1.3.6 Actividades realizadas .................................. 25

Capítulo II Marco Conceptual........................................... 29

2.1 Bienes jurídicos protegidos ...................................... 29

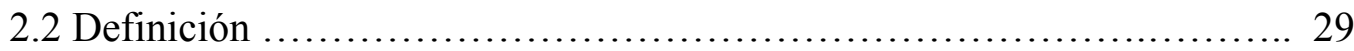

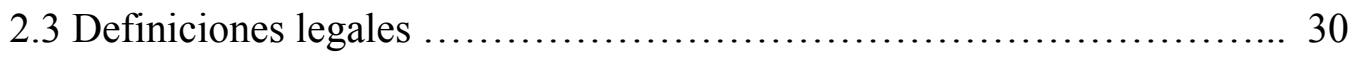

2.3.1 Legislación Nacional .................................... 30

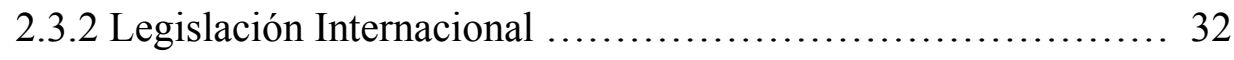

2.4 Definición Doctrinal ........................................... 34

2.5 Elementos del acoso sexual en el trabajo .......................... 37

2.6 Propuesta de definición y sanción de acoso sexual en el trabajo .......... 38

2.7 Manifestaciones del Acoso Sexual en el trabajo ...................... 38

2.8 Clasificación del Acoso Sexual en el trabajo .......................... 39

2.8.1 Por las circunstancias y actitud o comportamiento del agresor.... 39

2.8.2 Por las consecuencias en la relación de trabajo ................. 40

2.8.3 Por los sujetos ....................................... 41

2.8.4 Por el sexo ........................................... 42

2.8.5 De acuerdo con la jerarquía de los sujetos .................. 42 
2.8.6 En relación con el lugar donde se produjo .................... 43

2.8.7 En relación con el tiempo en que se produjo ................... 43

2.8.8 Por la edad de los sujetos ............................... 43

2.9 Responsabilidades ............................................ 43

2.10 Efectos en la víctima ......................................... 44

2.10.1 Efectos psicológicos y físicos ......................... 44

2.10.2 Repercusiones para el empleador ......................... 45

2.11 Medidas para prevenir, combatir y eliminar el Acoso Sexual............. 45

2.12 Procedimientos aplicables en materia de Acoso Sexual ................. 46

2.13 Publicación de la Organización Internacional del Trabajo (OIT)........ 48

2.13.1 Estadísticas claves......................................48

2.13.2 Lucha y prevención del Acoso Sexual ...................... 48

2.13.3 Juicios relativos al Acoso Sexual ............................ 49

Capítulo III Marco Jurídico, Estándares Internacionales y Obligaciones de los

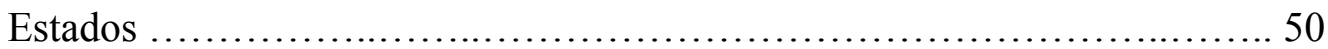

3.1 El Idealismo como baluarte de la positivización...................... 50

3.1.1 Jurisdicción Supraestatal ............................ 50

3.1.2 Derecho y Norma ...................................... 51

3.1.3 Obligaciones de los Estados: Sistema Internacional ............ 56

3.2 El Derecho Internacional de los Derechos Humanos: Definición-

Caracteres.........................................................63

3.2.1 Universalidad de los Derechos Humanos....................... 65

3.3 Falta de Legitimación del Gobierno Argentino....................... 65

3.4 Promover los Derechos Humanos ............................... 66

3.5 La Voluntad del Poder .......................................... 67

$3.6 \mathrm{El}$ Constitucionalismo moderno y Argentina ...................... 67

3.7 El Constitucionalismo social y Argentina............................. 68

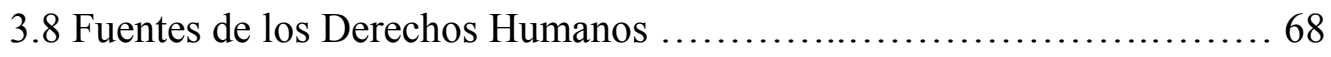

3.8.1 Constitución ............................................. 68

3.8.2 Los Tratados Internacionales ................................. 69

3.8.3 La Jurisprudencia ................................... 69

3.9 La internalización de los Derechos Humanos ..........................69

3.10 Valor en el Derecho Internacional............................... 70

3.11 Políticas Públicas Nacionales .................................... 70 
3.12 Actual situación institucional, económica y social de Argentina ...........74

3.13 Deber de Debida Diligencia ..................................... 76

$3.14 \mathrm{El}$ principio de la debida diligencia en casos de violencia de género...... 80

3.15 Debida diligencia, prevención y erradicación de la Violencia y la

Discriminación ................................................. 82

3.16 Deber de no discriminar ........................................... 84

3.17 La impunidad en los casos de violencia contra la mujer .............. 85

3.18 Obligación de los Estados y Derecho a la Información como derecho instrumental contra la violencia y la discriminación a la mujer.......... 88

a) La obligación de recolectar y producir información............... 88

b) La obligación de transparencia activa........................ 92

c) La obligación de responder de manera oportuna ................ 96

3.19 Organismos Internacionales de Derechos Humanos de América ......... 97

I) Naciones Unidas ......................................... 97

a) Órganos basados en la Carta de Naciones Unidas.................. 97

b) Órganos de Tratados........................................ 98

II) Organización de Estados Americanos....................... 99

A) Corte Interamericana de Derechos Humanos .................... 101

B) Comisión Interamericana de Derechos Humanos ............... 101

3.20 Normas Internacionales de Derechos Humanos obligatorias en violencia contra la mujer y en especial el acoso sexual laboral .............. 102

3.21 Algunas estadísticas que avalan el deber de diligencia (OAVL) ........ 106

3.21.1 Tipo de Violencia Laboral por rama de actividad............. 108

Capítulo IV Producción Legislativa e Informes a y de los organismos internacionales....................................................... 112

4.1 ONU y OEA ................................................... 112

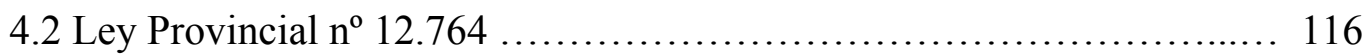

4.3 Ley de Protección Integral a las mujeres en Argentina................. 118

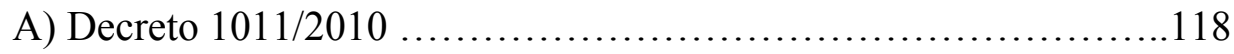

B) Convención Interamericana para prevenir, sancionar y erradicar la

Violencia contra la mujer .................................... 120 
4.4 Legislación vigente en Argentina antes de la sanción de la ley provincial. 123

1) Proyecto Tejedor-Código de Faltas...............................123

2) Decreto Nacional $n^{\circ} 2385 / 93$................................123

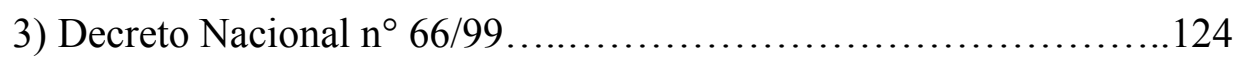

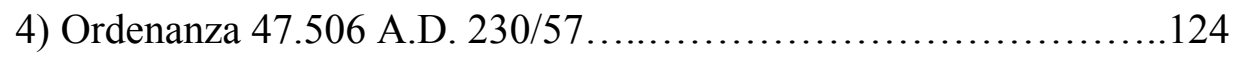

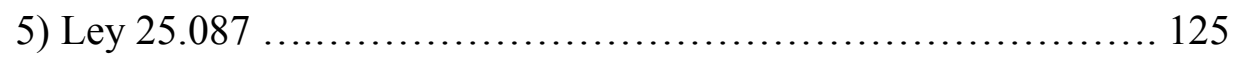

6) Sin embargo................................................125

4.5 Legislación vigente en Argentina por provincias antes y después de la Sanción de la ley ........................................... 127

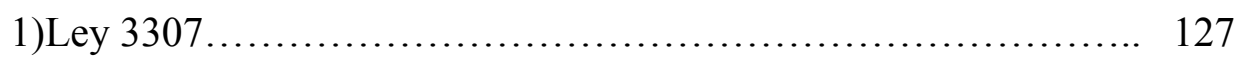

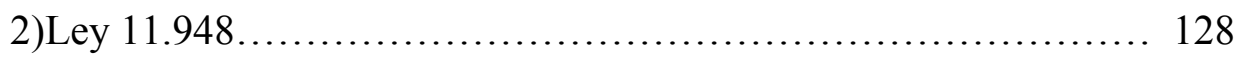

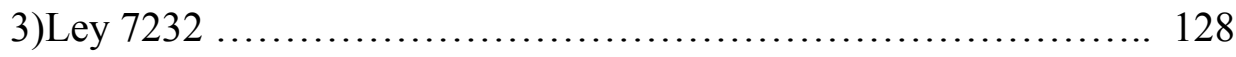

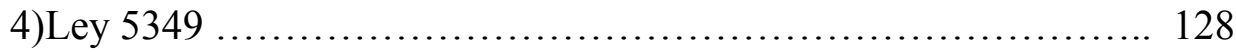

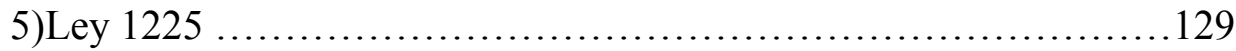

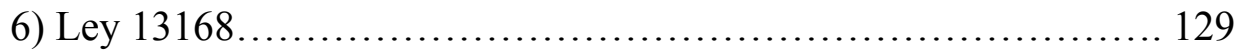

7) Convenio Colectivo de Trabajo............................. 129

8)Convenio Colectivo de Trabajo............................... 130

4.6 Informes a y de los Organismos Internacionales ................... 130

4.7 Responsabilidad del Estado Argentino ........................... 161

4.7.1 Fundamento .......................................... 161

4.7.2 Función de los Tribunales Internacionales .................... 162

Capítulo V Producción Jurisprudencial....................................... 164

5.1 Argentina...................................................... 164

5.2 Derecho Comparado ........................................... 166

5.3 Casos resueltos por la Comisión y por la Corte Interamericana de DH ...177

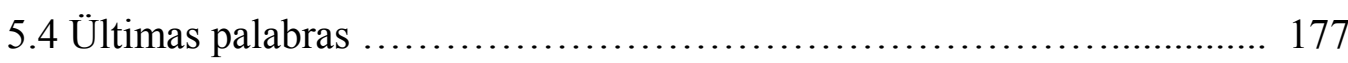

Capítulo VI Conclusión ................................................... 182

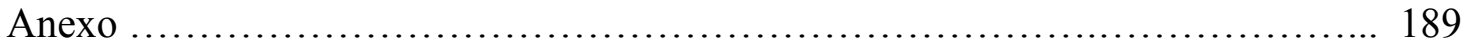

-Ley Provincial no 12.764 Documentación original Mesa de Entradas

Legislativa Expediente G-45/2000-2001 ............................. 189

-Asociación Judicial Bonaerense (nota de apoyo)........................ 190

-Coordinador General de Control de Gestión de la Provincia de Buenos

Aires-Área Gobernador (nota dirigida a esta maestranda (9/1/2001)....... 191 
-Nota dirigida a esta maestranda 30/3/2001

-Nota de apoyo de la Unión de Empleados Judiciales de la Nación Región

$\mathrm{N}^{\mathrm{o}} 5$ La Plata, 2/1/2000 193

-Nota elevación proyecto de Ley 12/12/2000 a la Gobernación provincial... 194

-Nota Elevación de Avales al Proyecto de ley presentado del 3/1/2001..... 196

-Nota del Secretario de Justicia al Presidente del Senado elevando el

Proyecto de ley de autoría de esta maestranda del 16/1/2001 198

-Nota del 24/1/2001 del Coordinador General de Control de Gestión a esta

Maestranda 203

-Tapa del expediente ingresado a la H. Cámara de Senadores. 204

-Exp. G-45/00-01 205

-Nota del H. Senado de la Pcia. de Buenos Aires al Coordinador General

De Control de Gestión sobre el proyecto de ley en trámite. 206

-Recorte periodístico Diario "El Plata” del 3/3/2001 210

Bibliografía 211 


\section{Capítulo I \\ INTRODUCCIÓN, TEORIA Y METODOLOGÍA}

\subsection{INTRODUCCIÓN}

El tema que nos ocupa en el presente trabajo, tiene como antecedente inmediato la redacción de un proyecto de autoría de esta maestranda que fuera elevado a la Honorable Cámara de Senadores de la Legislatura de la Provincia de Buenos Aires en Diciembre del año 2000. Y por ende debemos explayarnos someramente sobre la experiencia personal, sin que parezca que el presente padece de "falta de objetividad" porque así nacen las grandes obras, con sufrimiento (Ejemplo: las luchas de los pueblos para ser reconocidos en sus derechos, fueron a base de la sangre derramada de sus hijos en el campo de batalla y no por ello la historia es "poco objetiva" cuando relata los hechos) para de este modo exponer al lector a una búsqueda interesante del objetivo primordial de este trabajo. Fue así que recopilamos más de diez mil firmas e hicimos el proyecto de ley que además sostuvimos personalmente por espacio de trece meses de incansable lucha, por lo cual debimos instalar para nuestro resguardo una carpa frente a la gobernación misma, hasta que el día 20 de Septiembre del año 2001 nació la Ley provincial n ${ }^{\circ}$ 12.764, que prohíbe el Acoso Sexual Laboral en la Administración Pública Provincial.

Elegimos por ello el tema del acoso sexual laboral como una forma de violencia que padece la mujer - mayormente- y que a pesar que nace en épocas imposibles de determinar, para esta maestranda nació allá por 1998, cuando cumplía funciones en el Ministerio de Justicia y Seguridad de la Provincia de Buenos Aires. Adelantamos que existe desprotección por igual en toda la Argentina ante este fenómeno de violencia.

La mencionada Ley provincial llenó el vacío de décadas de indefensión a aquellos trabajadores dependientes de la administración pública, es muy completa y la única que específicamente habla sobre dicho ilícito en sus dos formas (quid pro quo y ambiental), ninguna ley en todo el país ni las poquísimas referencias provinciales que existen, hablan específicamente sobre el mismo, incluso no hay tratado internacional de Derechos Humanos que lo trate como única figura, y sólo se lo menciona en uno de ellos como una forma de violencia contra la mujer.

El gobierno nacional y cada uno de los provinciales, deben comprender la importancia de prevenir, y sólo se hará con el aporte de conocimientos difundidos por 
todos los medios posibles, incluso desde el hogar. Y para que se respeten los derechos de las personas sometidas a una de las más infames de las indiferencias del Estado, cual es la falta de justicia frente al pedido de protección y de reconocimiento del daño padecido, para eso es necesario comprometerse con el problema y ver su gravedad y reconocer las lagunas, hasta la inexistencia de la ley para actuar, y sobre todo la inexistencia de políticas públicas eficaces y concretas de las autoridades que tienen el deber de actuar para proteger a la población y no lo hacen ya sea por desidia, negligencia, indiferencia, o simplemente porque no hay voluntad de cumplir con los compromisos asumidos por Pactos Internacionales de Derechos Humanos.

Existe resistencia legislativa a encarar de frente estos problemas. Por ello, la presente tesis trata de dar a conocerlos y su posible solución, parcialmente lograda a través de la sanción de una ley específica, y extender a todo el país la conciencia de educación sobre esa lucha.

Se pretende, por otra parte, informar a las trabajadoras y poner a su alcance los elementos convenientes para su defensa legal; la que también podrá ser útil para trabajadores que se vean hostigados sexualmente en el trabajo.

Se anexa al presente además todo el documento que diera origen a la mencionada ley provincial.

Que la próxima ley no sea producto de la experiencia es lograr avances, y lograr avances es lograr que haya menos víctimas.

\section{2.- TEORÍA: AUTORIDAD DE LOS TRATADOS INTERNACIONALES DE DERECHOS HUMANOS.}

El objetivo de este estudio es explicar convincentemente la conducta del gobierno argentino en cuanto a su cumplimiento o no de las normas internacionales de Derechos Humanos en materia de acoso sexual laboral, y consideramos al Idealismo como la opción óptima para este fin. Sin embargo, también nos concentraremos en analizarla desde la óptica de la Teoría Realista; explicaremos de dichas teorías, someramente sus características y principios; $y$, finalmente, estudiaremos la relación de estas dos teorías con el acoso sexual laboral.

Como trabajaremos sobre los conceptos básicos de dichas teorías, daremos una 
síntesis de sus fundamentaciones. En relaciones internacionales, el idealismo promueve una diplomacia abierta y multilateral, regulada por el derecho internacional y los organismos internacionales. Se refiere pues a la línea de pensamiento que, en la historia diplomática estadounidense, se desarrolló en base a las ideas de Woodrow Wilson, y tal es así, que esta doctrina también es conocida como Wilsonianismo o Idealismo Wilsoniano. Según la escuela idealista, la finalidad de la política exterior debe ser el respeto de los valores morales, así como de los derechos del hombre. Esta primera posición es la médula de nuestro trabajo, es decir, el valor y fuerza del derecho internacional de los derechos humanos. Los idealistas compartían una perspectiva sobre el mundo basada en ciertas creencias:

- Los individuos son buenos por naturaleza, y su interés en el bienestar colectivo estimula el desarrollo económico y social a través de la cooperación posible y las ayudas institucionales y personales (El bienestar colectivo también se utilizará relacionado con el deber de debida diligencia).

- La naturaleza anárquica del sistema internacional no es inmutable ni permanente, y puede ser modificada o extinguida con el establecimiento y fortalecimiento de las organizaciones internacionales y el derecho internacional (ya mencionado ut supra).

- En líneas generales, los Estados democráticos no buscan la expansión militar y territorial. En cambio, generalmente los Estados con instituciones no representativas son dominados por élites autoritarias y agresivas, las que buscan afirmar y aumentar su poder.

- $\quad$ Es necesario garantizar la libertad individual y proteger a las personas de los abusos de poder que podrían cometer gobernantes y jerarcas en nombre de sus instituciones y en nombre del interés general (tendremos muy en cuenta el interés general o interés del Pueblo como interés nacional que debe perseguir Argentina en el cumplimiento de sus obligaciones internacionales).

Los programas principales de reformas idealistas consistieron principalmente en tres grupos de cuales nos interesa aquél que abogaba por la creación de instituciones internacionales para reemplazar el sistema anárquico de equilibrio de poder que predominaba la época anterior a la Primera Guerra Mundial. Este nuevo sistema estaría basado en el principio de la seguridad colectiva, el cual pretende que un acto de agresión por cualquier Estado sería percibido como agresión hacia todos los Estados. 
La Sociedad de Naciones encarnó este principio, al reflejar el énfasis idealista en la posibilidad de la cooperación internacional como mecanismo principal para resolver problemas globales. Resulta así que nuestro problema de estudio relaciona tanto los organismos internacionales, su autoridad, como los compromisos a través de la firma de tratados entre los Estados Partes, las fuentes de derecho internacional como los mismos tratados o resoluciones, dictámenes, documentos todos vinculantes para los Estados Partes tanto los emitidos por las Comisiones como por las Cortes de justicia internacional de orden regional (OEA) y universal (ONU) a las que Argentina reconoce jurisdicción especialmente en el Derecho Internacional de los Derechos Humanos. Todo ello para demostrar la obligatoriedad de dichas fuentes para nuestro país y las consecuencias internas e internacionales que su incumplimiento acarrea.

Para seguir avanzando necesitaremos definir conceptos claves como: Acoso Sexual Laboral, normas internacionales de Derechos Humanos, bienestar público e interés nacional. Brevemente, pues ampliaremos en otros capítulos, diremos que Acoso Sexual Laboral en el concepto acuñado en la Universidad de Cronwell, en 1974, es aquel que una persona realiza de forma indebida, por cualquier medio, requerimientos de carácter sexual, no consentidos por quien los recibe y que amenacen o perjudiquen su situación laboral o sus oportunidades de empleo; las normas internacionales de Derechos Humanos, son aquellas normas del Derecho Internacional Contemporáneo que protegen las "condiciones instrumentales que le permiten a la persona su realización" en consecuencia subsume aquellas libertades, facultades, instituciones $o$ reivindicaciones relativas a bienes primarios o básicos que incluyen a toda persona, por el simple hecho de su condición humana, para la garantía de una vida digna, «sin distinción alguna de raza, color, sexo, idioma, religión, opinión política o de cualquier otra índole, origen nacional o social, posición económica, nacimiento o cualquier otra condición».

En tanto bienestar público o social se le llama al conjunto de factores que participan en la calidad de la vida de la persona y que hacen que su existencia posea todos aquellos elementos que dan lugar a la tranquilidad y satisfacción humana y que debe ser otorgado por el Estado. El bienestar, como concepto abstracto que es, posee una importante carga de subjetividad propia del individuo, aunque también aparece correlacionado con algunos factores económicos objetivos. Y el Interés público, interés 
general o interés nacional es denominación de un concepto esencial de las ciencias políticas, con muy distintas expresiones (res publica, commonwealth, "procomún", etc.), pero siempre identificable con el bien común de la sociedad entera, entendida como un cuerpo social, y no tanto con el interés del Estado en sí mismo (razón de Estado). La expresión se usa para reflejar el postulado de que la finalidad de las acciones del Estado, o de las instituciones de una comunidad políticamente organizada, ha de ser el bien (felicidad, interés, utilidad o beneficio) del conjunto del pueblo (la totalidad de los que componen una nación). Y la defensa de los intereses nacionales es el propósito declarado de la acción exterior de los Estados.

Por último, el derecho internacional de los derechos humanos establece las obligaciones que los Estados deben respetar. Al pasar a ser partes en los tratados internacionales, los Estados asumen las obligaciones y los deberes, en virtud del derecho internacional, de respetar, proteger y realizar los derechos humanos. La obligación de respetarlos significa que los Estados deben abstenerse de interferir en el disfrute de los derechos humanos, o de limitarlos. La obligación de protegerlos exige que los Estados impidan los abusos de los derechos humanos contra individuos y grupos. La obligación de realizarlos significa que los Estados deben adoptar medidas positivas para facilitar el disfrute de los derechos humanos básicos. A través de la ratificación de los tratados internacionales de derechos humanos, los gobiernos se comprometen a adoptar medidas y leyes internas compatibles con las obligaciones y deberes dimanantes de los tratados. En caso de que los procedimientos judiciales nacionales no aborden los abusos contra los derechos humanos, existen mecanismos y procedimientos en el plano regional e internacional para presentar denuncias o comunicaciones individuales, que ayudan a garantizar que las normas internacionales de derechos humanos sean efectivamente respetadas, aplicadas y acatadas en el plano local.

Y, por otro lado, a manera de resumen y con el propósito de lograr una comprensión más clara de lo que propone el Realismo, Hans Morgenthau expone una lista de los principios básicos de esta filosofía:

1 - Los Estados, al interactuar con las demás naciones en el sistema internacional, van a adoptar el deseo por poder que caracteriza a la naturalezahumana.

2- Los intereses de los Estados se definen en términos de poder. Las naciones van a cohabitar en una eterna lucha por el poder que les permita 
satisfacer sus intereses, en otras palabras, van a buscar la forma de influenciar a otras naciones para beneficio propio.

3- El interés que motive la política exterior de un país va a depender del periodo histórico, y del contexto político y cultural que lorodee.

4- Las acciones de un Estado no pueden basarse en las mismas leyes éticas y morales que las acciones a nivel personal. La ética política juzgará únicamente las consecuencias políticas. El Realismo identifica las tentaciones que sufren las naciones por encubrir sus actos y aspiraciones egoístas con los propósitos de la moral universal.

5- El Realista reconoce la existencia de criterios no políticos, pero de ninguna manera subordina la política a estos criterios. Los autores Realistas insisten en la autonomía del entorno político y analizan las relaciones internacionales en términos de interés (definidos como poder).

Habiendo descripto, a grandes rasgos, la manera en la que el Realismo explica el comportamiento del sistema internacional, proseguiremos con la comparación entre esta filosofía política y la Teoría Idealista de las relaciones internacionales.

\subsubsection{Comparación entre el Realismo y el Idealismo:}

Como ya lo habíamos establecido previamente, este estudio tiene como meta presentar una explicación del comportamiento gubernamental argentino en cuanto a su política interna de aplicación de los tratados internacionales de Derechos Humanos en el tema del acoso sexual laboral, nuestra interpretación la daremos desde dos ópticas, de la Teoría Idealista de las relaciones internacionales y veremos también que el Estado Argentino actúa domésticamente utilizando otra teoría: la Realista. Es importante señalar que el Idealismo es la teoría de las relaciones internacionales que más contradice al Realismo.

El Idealismo afirma que todos los países en el mundo conviven en una sola comunidad internacional, donde las acciones entre naciones 
deben estar regidas por los ideales de la humanidad y deben perseguir beneficios en común. Existe una armonía entre los intereses verdaderos de los países. Los autores Idealistas establecen como la esencia de la comunidad internacional a los valores morales y a la buena voluntad del hombre.

La Teoría Idealista considera que las acciones de los Estados deben recibir los mismos juicios morales que reciben las relaciones a nivel personal. La conciencia del hombre va a guiar las políticas exteriores de las naciones, por consiguiente, las naciones actuarán de acuerdo a la razón y al bienestar en común; ninguna nación deberá actuar en detrimento de otra, ya que los medios son tan importantes como el fin que persiguen. Para el Idealista, las guerras en la comunidad internacional, en gran medida, son provocadas por los actos individuales y egoístas de ciertos líderes, a costa del beneficio de las poblaciones. Pueden ser controlados mediante leyes $\mathrm{y}$ organismos internacionales estructurados bajo los estándares de la ética. Y como vimos anteriormente, los Realistas en contraposición, afirman que el Estado no puede ser sometido a la autoridad de otro ente superior, ya que el Estado es soberano, y por encima de él no hay nada más, y para subsistir debe acumular poder y llegar a ser hegemónico (imperialismo) o líder en un reducido grupo de Estados para que haya equilibrio de poder en el mundo, ya que las relaciones internacionales son relaciones de poder (militar) y no le caben las normas individuales de moral y éticas de la persona humana para juzgarlo. Por ello, los Estados que siguen las teorías Realistas, no aceptan la jurisdicción supraestatal, caso de Estados Unidos con Morgenthaw. También están aquéllos Estados que aceptan la jurisdicción supraestatal a quienes calificaría en principio como adherentes a la Teoría Idealista, pero en la práctica no acatan las normas internacionales (ya sea porque no adecuaron su legislación interna a la internacional por no dictar leyes que las incorporen o habiendo dictado tales leyes, éstas carecen de vigencia sociológica por no aplicarlas) pareciendo más bien sustentar la teoría Realista en este sentido.

1.2.2 Relación entre la Teoría Realista e Idealista con el Acoso Sexual Laboral en Argentina. 
Para clasificar la política en materia de acoso sexual laboral que aplica un Estado como Realista o Idealista, hay que comenzar por localizar la fuerza que motiva sus acciones. Cuando las políticas están basadas en los intereses nacionales, estas serán de carácter Realista; y si se basan en los ideales nacionales, entonces son Idealistas. En este estudio definiremos a los intereses según el realismo- como las negociaciones de un Estado para obtener un beneficio propio, sin importar a quién se afecte o se perjudique. Por otro lado, los ideales los consideraremos como las relaciones con el exterior que busquen valores morales universales y bienes en común (o sea, que trascienden los intereses nacionales).

Hay que señalar que existen varios tipos de intereses y principios (los principios morales que consideramos para este estudio son los que comparte la cultura occidental, es importante señalarlo debido a que no todas la culturas tienen las mismas creencias y valores), no hay que tomarlos como un solo bloque homogéneo. Las distintas clases son las siguientes:

\section{$\underline{\text { Intereses }}$}

- La sobrevivencia del Estado: Es el interés primordial de toda nación; lo constituye la integridad territorial, independencia política, y la existencia de las instituciones gubernamentales fundamentales.

- Los intereses vitales: Estos intereses incluyen las oportunidades de comercio equitativas, la protección de propiedades y ciudadanos residiendo en el extranjero, y el control de inmigración.

- Autonomía: Es la soberanía de una nación para conducir las relaciones exteriores sin consultar con otros Estados. Este apartado se divide en dos políticas: egoísmo pasivo y egoísmo agresivo. El pasivo, también conocido como aislacionismo, consiste en la retirada de una nación del orden internacional deseando que se le deje en paz. El egoísmo agresivo lleva a las naciones a imponer su voluntad sobre otras, sin importar a quien perjudica.

- Honor: Nos referimos al respeto de otras naciones hacia la reputación y acciones de un Estado auto-suficiente, también incluye la admiración a la moral de un país. El prestigio se obtiene con la 
aprobación de otras naciones para ejercer sobre ellas el poder de la fuerza moral. Este tipo de interés ha sido fundamental, por ejemplo en la estructuración de la política exterior de los Estados Unidos.

\section{$\underline{\text { Ideales }}$}

- La dignidad innata en los hombres: Todo individuo tiene el derecho de la libertad e igualdad entre los hombres, el trato entre los hombres debe ser considerado como el fin y no como un medio para obtener determinado beneficio.

- Principios de buena conducta: Los mismos valores que reglamentan las relaciones entre individuos, como la honestidad y la amabilidad, deben regular las relaciones entre Estados.

- Metas universales: Las naciones deben perseguir beneficios para la totalidad del escenario internacional; tales como la paz, la buena voluntad, la justicia entre naciones, la libertad, y un buen nivel de vida para todos los hombres.

- Sacrificios: Es la forma del idealismo más extrema, la nación debe renunciar a un beneficio para su propia población para que los habitantes de otra se beneficien.

Ahora nos hacemos la pregunta fundamental de nuestro análisis: ¿En qué categoría cae Argentina y por qué? En nuestra opinión, ha sido una constante a través del tiempo que el ciudadano argentino sobrestime la importancia que tienen los ideales y principios morales en la formulación de la política doméstica de su nación, y al mismo tiempo subestime el valor de los intereses propios. En otras palabras, la clase política gobernante se escuda en un Idealismo para tener que justificar sus acciones $\mathrm{u}$ omisiones ante otras naciones, cuando en realidad su política doméstica básicamente pertenece a un enfoque Realista (por la no aplicación real de Tratados que hacen referencia al acoso sexual laboral).

Argentina con la firma de los Tratados Internacionales de Derechos Humanos asegura que el funcionamiento y organización de sus instituciones gubernamentales serán acordes a dichas normativas. Y por ende se someterá a la jurisdicción de los tribunales internacionales regionales o universales. Pero 
en la práctica no aparece reflejado en las normas internas ese compromiso, o directamente son nulas, o si aparecen en grado mínimo resulta que no llegan a cobrar vigencia sociológica porque no son aplicadas, muchas veces informado así por la Organización de Estados Americanos (OEA) o por las denuncias entabladas contra el Estado Argentino por particulares víctimas ante el fracaso de la Justicia en el país, incluso por la escasísima jurisprudencia sobre el tema.

\section{3.- METODOLOGÍA}

1.3.1.- Problema de Investigación: Violación o cumplimiento de Argentina en la aplicación de los Tratados de Derechos Humanos (OEA, ONU) en materia de Acoso Sexual Laboral en la Administración Pública.

El acoso sexual en el trabajo es un nuevo término que describe un viejo problema. El acoso sexual en el trabajo está llegando a ser reconocido, cada vez más, como un problema grave. Está indisolublemente unido al poder. Por ello, creemos que es desde el poder político mismo que deben darse las garantías máximas para defenderse efectiva y apropiadamente de este grave problema cuando la Comisión Interamericana de Derechos Humanos misma ha señalado que la omisión por el Estado -que provoca violencia institucional- es una forma de tortura. Nuestro país se comprometió a realizar una serie de acciones para proteger a las personas del Acoso Sexual, al suscribir documentos internacionales contra la violencia de género en general, como la Declaración de la eliminación de la violencia contra la mujer (1993) de orden universal, la Declaración Americana de derechos humanos (1948), la Convención Americana de derechos humanos (1969), el Protocolo de San Salvador (1988), la Convención Interamericana para prevenir, sancionar y erradicar la violencia contra las mujeres o Convención de Belém do Pará (1994), la Convención para la eliminación de todas las formas de discriminación contra la mujer todos de orden regional. En materia legislativa se han aprobado muy escasas normas vinculadas con el reconocimiento de los derechos humanos de las mujeres en el tema que nos ocupa, tanto a nivel nacional como provincial. La mayor dificultad que enfrenta la Argentina es la brecha existente entre el derecho formal y el derecho en la acción, que se evidencia en la escasa 
utilización de los procedimientos y normas legales disponibles, entre otros. Por ello, para algunos autores (Julio J. Martínez Vivot, 1995; Humberto Quiroga Lavié, 1995; Elpidio González, 1996; José Miguel Vivanco, 1996; Zunilda Rosa Valenciano 2007; Dr. Daniel Cieza, 2010; Comisión Interamericana de Derechos Humanos 2011; Equipo Latinoamericano de Justicia y Género, 2012) Argentina no ha procedido a cumplir con las directivas emanadas del derecho internacional de los derechos humanos sobre acomodar sus leyes internas a dichas normas o para el caso de existir alguna norma de rango inferior, debió asegurar el efectivo ejercicio de los derechos y la reparación a la víctima de tal flagelo e incumplido además otras importantes obligaciones como el derecho a la información pública y confección de programas, diseño de políticas, protocolos, estadísticas, capacitación, entre otras. Otros Estados parte se encuentran en la misma situación.

Para otros autores que han escrito desde sus funciones gubernamentales (Consejo Nacional de la mujer, 2012) en cambio, ven que Argentina va hacia la concreción con éxito de los compromisos asumidos por los Tratados internacionales de Derechos Humanos en el tema que nos ocupa aunque emiten silencio cuando deben informar a los organismos internacionales específicos sobre el tema (Ej: CEDAW) respecto de su función e implementación de dichos Tratados. Ese será nuestro mayor desafío, dilucidar verdaderamente la posición de Argentina como país que se debate entre ser considerado infractor internacional de los Derechos Humanos en materia de Acoso Sexual Laboral en el ámbito de la Administración Pública o país cumplidor que espera alcanzar todos sus compromisos asumidos.

Con respecto al acoso sexual, podemos afirmar que éste se manifestó desde que la humanidad nació. Entonces, ¿Por qué si los casos sobre acoso sexual se multiplican en nuestro país, no hay estadísticas que señalen aumentos o disminución del flagelo?; ¿por qué no existen oficinas especializadas en todas las áreas de la administración pública para investigar y actuar de inmediato?; ¿por qué hay desconocimiento de las leyes, de los derechos que rigen de fácil acceso para las unidades de análisis?; ¿por qué las investigaciones estatales para evitar más casos son casi nulas?; ¿por qué hay muy poca jurisprudencia?; ¿ debe responder el Estado ante tales omisiones? ¿Por qué avanzó o retrocedió, nuestro país sobre la protección jurídica con respecto a otros países más y menos desarrollados? ¿Por qué no se aplican los tratados internacionales de derechos humanos emanados de la Organización de Estados Americanos y los de las Naciones Unidas sobre el tema? 
En definitiva, nuestro problema es: ¿Por qué Argentina se debate entre ser país cumplidor en la aplicación de los Tratados de Derechos Humanos (OEA, ONU) en materia de Acoso Sexual Laboral en la Administración Pública o ser país infractor por carecer de la debida diligencia a la hora de cumplir con sus compromisos asumidos?

Esto es lo que ha llevado a los autores a preguntarse si Argentina en lugar de comportarse de acuerdo al sistema internacional de los derechos humanos, no se estaría volviendo un violador de las garantías constitucionales que dice respetar. La cuestión divide las opiniones y es aún un debate abierto. Precisamente en esa discusión de procesos simultáneos y contradictorios, el de la violación y el del cumplimiento legal, es donde ubicamos el estudio del fenómeno que se dispersa entre los países americanos incluído E.U, y países de Europa además de nuestra Argentina.

\subsubsection{Nuestra Hipótesis y Variables:}

Hemos analizado hasta aquí las teorías y conceptos sobre el valor normativo asignado a los organismos internacionales creadores de los Tratados Internacionales de Derechos Humanos contenidos en nuestra Constitución Nacional (art. 75 inc. 22). También brevemente analizamos el estado de la cuestión en Argentina y planteamos nuestra problemática en torno al fenómeno de la violación de los derechos humanos en el acoso sexual laboral en el país. Cabe aclarar que la literatura disponible aún no ha explorado suficientemente la relación de influencia de los actores claves de América, con E.U por un lado y los países europeos, por el otro, respecto de Argentina, para comprender y explicar ese fenómeno de ser país infractor o no. Por ello, tomando como dato los márgenes de acción en el orden internacional vigente, nos propusimos investigar la influencia de dichas regiones, a partir de la información y análisis de sus respectivos antecedentes jurisprudenciales y normativos. En virtud de ello, la hipótesis que manejamos para responder a nuestro problema es la siguiente: Argentina es un país infractor a nivel internacional en materia de Derechos Humanos en atención al acoso sexual laboral en la administración pública porque ella no cumple con su obligación legal emanada de los Tratados Internacionales de Derechos Humanos explicándose porque no hay normas específicas que sean obligatorias en todo el país, ni aplicación efectiva de las normas internacionales ni resultados favorables, ni siquiera estadísticas sobre las que se estructuren las soluciones, en comparación con los avances logrados 
tanto en los países de la región (por ejemplo: EU, países latinos) como en países europeos.

Nos proponemos, entonces, analizar el fenómeno de incumplimiento de los compromisos asumidos por Argentina en nuestro tema, a través del estudio de la evolución lograda en países americanos y europeos que, durante nuestro período de análisis, tuvieron voluntad política traducida en la creación de normas y en su aplicación efectiva como para llevar adelante dichos compromisos con su comunidad y con la comunidad internacional.

Dado nuestro problema de investigación, identificamos como variable dependiente al proceso de incumplimiento de los compromisos asumidos en el sistema internacional de los derechos humanos por parte del gobierno de Argentina, en el marco del proceso de la evolución normativa y jurisprudencial dada en América y en Europa. Siendo la delimitación espacial circunscripta al ámbito americano y al europeo. El recorte de nuestro objeto de estudio se completa con la siguiente delimitación temporal: se tomó como punto de partida la sanción de la Ley provincial (Buenos Aires) $n^{\text {o }} 12.764$ del 21/9/2001 dado que, según nuestro parecer, allí comenzó la construcción jurídica plena con el establecimiento de un mecanismo propio, íntegro, específico de defensa, comprobación de los hechos, y sanción para los acusados que demuestra la existencia plena del Derecho internacional de los Derechos Humanos aunque la norma fue hecha por parte de un particular y no por acción del gobierno quien se desentendió de todos los proyectos presentados con once años de anterioridad (ese particular es esta maestranda). Aunque el incumplimiento estará marcado por la inexistencia de datos estadísticos y por ende, de la falta de información pública que prueben la puesta en marcha de tales normas y la imposibilidad de valorar así su eficacia.

El período de investigación se extiende hasta el año 2015 en cuanto a Argentina, y sólo la década de 1990 para el estudio de los ejemplos en países americanos (salvo Estados Unidos que fue muy anterior) y europeos. Esto último por ser la década mencionada la que eclipsara al mundo en el surgimiento de las normas legales y la jurisprudencia tan valiosa que satisface plenamente el objeto de estudio.

Dedicaremos el próximo capítulo a analizar los antecedentes de la cuestión del acoso sexual para explicar su conformación y evolución y caracterizarlo.

Por su parte, nuestra variable independiente será la falta del deber de debida diligencia en comparación con los avances logrados tanto en los países de la región (por ejemplo: EU, latinos) como en países europeos. De esa forma, podemos definir el 
objetivo general de nuestra investigación como el de analizar el desarrollo de los procesos de aplicación y protección jurídica de las normas internacionales de derechos humanos emanadas de la OEA y de la ONU contra el acoso sexual laboral, en la Administración Pública en Argentina y del derecho comparado de los países más relevantes de la región americana (E.U, latinos) y europea para demostrar la falta del deber de debida diligencia por nuestro país. Veremos cómo la acción de los estados más influyentes de América, en el periodo de tiempo señalado, incidió en el resultado que obtendremos, de incumplimiento y transgresión de esas normas por Argentina.

Definiremos nuestros indicadores: Nuestra única variable independiente centrada sobre la falta del deber de debida diligencia por Argentina que se justifica por los avances logrados en la materia por los principales países de la región americana y europea en cuestiones de derechos humanos, determina que consideremos como indicadores a: 1) la producción legislativa de Argentina frente a la que surge de los organismos internacionales (OEA, ONU) con respecto a lo que produjeron los principales países; 2) la producción jurisprudencial tanto en el país como en otros países delimitados.

Como objetivos específicos: a) Caracterizaremos la evolución de la normativa sobre el acoso sexual laboral en Argentina y en los países más avanzados sobre el tema para comprobar los intereses que motivaron el éxito o el fracaso de sus normas; b) Describir las políticas públicas de Argentina para desentrañar su modelo de inserción internacional en el universo de los derechos humanos del acoso sexual laboral; c) Explicar el impacto de las políticas públicas en materia de acoso sexual laboral de Argentina más relevantes para comprender el nivel de incidencia que han tenido en el éxito o fracaso en la aplicación de las normas internacionales teniendo en cuenta los resultados al respecto en los países a estudiar.

\subsubsection{Objetivos:}

Llevaremos a cabo un estudio profundo de la normativa nacional e internacional específica sobre el Acoso Sexual Laboral en la Administración Pública en Argentina para demostrar que en el tiempo estudiado delimitado por el problema, el Estado infringió las normas de Derechos Humanos que se comprometió respetar y ejecutar. Para ello realizaremos una investigación con validación conceptual, aplicando un 
método cualitativo de investigación documental (teórica) porque nos centraremos en aspectos específicos de la realidad en un tiempo y lugar determinados en la hipótesis, no buscando leyes generales. El tipo de estudio será exploratorio, descriptivo y explicativo a través de un diseño emergente. Desde una visión ontológica aceptamos que la realidad se construye socialmente, por lo tanto, no es independiente de los individuos como lo considera el método cuantitativo, las realidades múltiples y socialmente construidas exigen procesos interpretativos y comprensivos.

\subsubsection{Unidad de Análisis:}

Nuestro estudio se centrará en Argentina sobre la población de trabajadores empleados públicos, especialmente las trabajadoras, además de tratar las normas internacionales y autoridad de los organismos internacionales regionales (OEA) y universales (ONU); sobre aspectos del problema desde 1995 hasta 2015 en Argentina y sólo la década de 1990 en el resto de los países a estudiar como ejemplos.

\subsubsection{Búsqueda y selección de información:}

La investigación abarcará el período desde 1995 hasta 2015 en Argentina y sólo la década de 1990 en el resto de los países a estudiar.

Elegimos a países europeos (Ej:Francia, España) y los de la zona americana (Ej: E.U, latinos) para estudiar como ejemplos de la evolución de la legislación comparada en dicha materia. Mencionamos que Francia es el más evolucionado por haber añadido en su legislación penal la protección a la víctima del delito -que define- de acoso sexual; a España como aliado de los trabajadores al haber añadido como contrario a la salud de los mismos dicho flagelo; a E.U. como fundador de una jurisprudencia que será tomada luego por varios países en defensa de las víctimas estableciendo claramente con el tiempo los derechos y circunstancias.

\subsubsection{Actividades realizadas:}

1) La técnica que se ajustó más a la investigación para la producción de datos fue la de análisis de documentos (bibliografía básica y la que surja de la investigación, fallos nacionales e internacionales, normas de derechos humanos, Constitución Nacional Argentina, informes dictámenes y resoluciones de los organismos internacionales) de donde extrajimos las posturas sostenidas por cada autor sobre el problema, además de observación participante que resultó en un relato descriptivo del ambiente o práctica en 
que se desarrolla aquél. Así de este modo obtuvimos la información que existe a la fecha sobre el tema elegido en el mundo normativo interno y demostramos la coherencia, la aplicación, la adecuación del derecho internacional de los derechos humanos en el país para comprobar la hipótesis final. Comparamos las legislaciones sobre el tema tanto en países latinos como europeos, pero en los más relevantes así como en Estados Unidos con respecto a Argentina. Verificamos si los Tratados Internacionales en materia de acoso sexual laboral tienen expresión en la legislación interna y en qué medida.

2) Hicimos ajustes al Proyecto;

3) Fichamos según Variables e Indicador;

4) Articulamos los datos obtenidos con el marco teórico;

5) Analizamos los datos;

6) Elaboramos los capítulos;

7) Evaluamos y correjimos borradores;

8) Redactamos la Tesis;

9) Evaluamos, correjimos y produjimos el resultado final.

La discriminación por género, abarca temas relacionados con el hostigamiento sexual. Al inicio se verán los conceptos de acoso sexual laboral, las leyes que rigen en el país y enseguida se analizará el problema del incumplimiento referido en el análisis de las políticas públicas nacionales o su inexistencia, en el estudio de los informes elevados a los organismos internacionales y la respuesta de éstos, la relación directa con el deber de debida diligencia y los intereses nacionales que no son precisamente el bienestar general de la población lo que queda al descubierto ante la no vigencia del derecho internacional de los derechos humanos en nuestra investigación. Asimismo se hará una breve descripción de sentencias con el señalamiento del marco legal citando disposiciones concretas en las leyes nacionales y las relativas a la legislación internacional obligatorias en el país, así también dando ejemplos de las normas en los diferentes países más evolucionados en la materia. En esta presentación se señalará la escasa jurisprudencia en estos asuntos.

Ahora explicaremos la estructura en que hemos dividido la Tesis en seis capítulos, con un lazo muy fuerte entre cada uno de ellos para evolucionar así hasta la 
"Conclusión" donde se puede ver que llegamos a alcanzar los objetivos planteados. En el Capítulo I introdujimos las teorías con las cuales interpretamos el hecho investigado (Idealismo-Realismo); planteamos la metodología que nos sirvió para dar cada paso en el proceso. Debíamos dar los conceptos jurídicos de nuestros elementos observados, y así hicimos en el Capítulo II, en el siguiente mostramos el Marco Jurídico de nuestra Hipótesis y nos abocamos al estudio del Derecho Internacional de los Derechos Humanos, su valor, caracteres, fuentes y dentro de éstas las leyes y tratados internacionales que emanan de las organizaciones internacionales nacidas de las distintas convenciones y pactos suscriptos por Argentina sometiéndose así a la jurisdicción de tribunales internacionales indefectiblemente en materia de derechos humanos, y dentro de éstos ubicamos el derecho a no padecer de acoso sexual laboral. Hablamos también del principio de debida diligencia como parte de nuestras variables, y del deber de acceso a la información como parte de alcanzar nuestros objetivos específicos a través de los datos que debieran darse públicamente por los órganos del Estado. Allí también nos referimos a las políticas públicas de Argentina al tener relación con otro de nuestros objetivos y tratamos finalmente los Organismos Internacionales para explicar el papel reservado por el sistema internacional a este tipo de instituciones en la creación de derecho internacional y de fuertes organismos jurisdiccionales con poder de emitir opiniones consultivas o dictámenes y sentencias obligatorias para el Estado firmante de los Tratados que las han creado, demostrando así su jerarquía supraestatal, a los fines de fortalecer la conclusión a la que arribamos sobre nuestra hipótesis alcanzada, de la existencia de un marco jurídico universal que en materia de derechos humanos Argentina debe respetar aplicando sus normas en lo doméstico, y lo fundamentamos en la doctrina naturalista del derecho en oposición a los positivistas (que pareciera adoptar Argentina con su omisión de debida diligencia).Y ya para el Capítulo IV trabajamos con nuestros indicadores de la única variable independiente, y analizamos la evolución y el proceso de maduración legislativa de los distintos países de América o de Europa -aunque se mencionaron algunos de zonas más distantes como Australia, Japón, etcétera- necesarios para luego confrontar con lo que sucedía en Argentina y deducir por último nuestro objetivo general. Remarcamos la existencia de muy pocas normas y leyes internacionales sobre nuestro tema de investigación. Agregamos los informes de los organismos internacionales y las respuestas de Argentina como apoyo para lograr nuestros objetivos y nos referimos también aquí a la responsabilidad internacional de Argentina. Confrontamos al analizar el contenido de 
cada Tratado de Derechos Humanos (con indicación de su fuente) con jerarquía constitucional o sin ella, sus dones y sus limitaciones, la legislación de Argentina. Ya en el siguiente Capítulo $\mathrm{V}$, donde también trabajamos con el último de nuestros indicadores, desarrollamos el proceso de evolución en el mundo -sólo los países a tratar- de la jurisprudencia sobre el tema acoso sexual laboral y en nuestro país (sólo remarcamos los fallos que encontramos y sus aportes, dejando para el lector su lectura in extenso), confrontamos así y llegamos a la incipiente intención de los tribunales argentinos por hacer lugar al derecho de las víctimas destacando la labor de evolución que se destacó en la jurisdicción norteamericana, por ejemplo, que marcó una etapa donde el derecho a no padecer de acoso sexual laboral pudo materializarse. Por último, la Conclusión en el Capítulo VI, a la que arribamos después de un detallado y pormenorizado pulido de cada paso dado estando seguros de haber conseguido dar luz al hecho investigado y su situación en la órbita internacional y su estado en Argentina, capítulo al cual analizaremos debidamente sin adelantar más detalles.

La bibliografía citada, con excepción de los Convenios y Convenciones Internacionales, como bien se observa corresponde en su mayoría a obras publicadas en los últimos diez años, donde se incluyen los informes y dictámenes de los organismos internacionales (entre ellos, la Comisión y la Corte Interamericana de Derechos Humanos). 


\section{Capítulo II. MARCO CONCEPTUAL}

\subsection{BIENES JURÍDICOS PROTEGIDOS}

El acoso sexual laboral constituye una expresión de violencia que conculca el derecho al trabajo, a la salud, a la educación, y a la seguridad; implicando una práctica violatoria de la dignidad humana que provoca consecuencias sumamente perjudiciales sobre la integridad psíquica y física, la confianza, la autoestima, y sobre el rendimiento de las personas que lo padecen. Por lo que distintos investigadores coinciden en precisar que los bienes jurídicos protegidos serán la integridad física, psíquica y moral, la libertad sexual, la dignidad e intimidad de la persona, el derecho a un ambiente saludable y armonioso y al bienestar personal.

\subsection{DEFINICIÓN}

Como forma de violencia, podemos decir que es una forma de violencia de género, y sobre ésta encontraremos las definiciones más apropiadas en las propias convenciones de protección a la mujer, tales como la siguiente: Discriminación contra la mujer: "Artículo I: A los efectos de la presente Convención, la expresión "discriminación contra la mujer" denotará toda distinción, exclusión o restricción basada en el sexo que tenga por objeto o por resultado menoscabar o anular el reconocimiento, goce o ejercicio por la mujer, independientemente de su estado civil, sobre la base de la igualdad del hombre y la mujer, de los derechos humanos y las libertades fundamentales en el campo político, económico, social, cultural y civil o en cualquier otra esfera" (Convención sobre la Eliminación de todas las formas de discriminación contra la mujer, Asamblea general de la ONU del 18-12-1970. Ley 23.179). Con respecto a la diferenciación sobre Sexo y Género, el sexo hace referencia a las características biológicas que diferencian a los hombres de las mujeres. Sin embargo, el género atiende a las oportunidades y funciones que son asignadas a cada persona por el hecho de ser hombre o mujer. A diferencia de los rasgos biológicos, estos roles que atienden al género de la persona son convenciones sociales construidas y aprendidas con el tiempo. Por esta razón, las características de cada género son diferentes en cada cultura y van siendo modificadas con el tiempo.

Mientras que violencia contra la mujer está definida por: Artículo 1: “A los efectos de la presente Declaración, por "violencia contra la mujer" se entiende todo acto de violencia basado en la pertenencia al sexo femenino que tenga o pueda tener como 
resultado un daño o sufrimiento físico, sexual o sicológico para la mujer, así como las amenazas de tales actos, la coacción o la privación arbitraria de la libertad, tanto si se producen en la vida pública como en la vida privada" (Declaración sobre la eliminación de la violencia contra la mujer, ONU, 20 de diciembre de 1993).

Ahora, el término acoso se utiliza como sinónimo de hostigamiento. Acosar, refiere una acción de persecución. Perseguir, apremiar, importunar a una persona con molestias o requerimientos, como lo señala en tercer sentido el Diccionario de la Lengua Española Real Academia Española, 21a. ed., Espasa Calpe. Hostigamiento, del verbo hostigar significa también perseguir, molestar. El mismo diccionario lo define así: “...molestar a uno, ya burlándose de él, ya contradiciéndolo, o de otro modo. Incitar con insistencia a alguien para que haga algo..."

Ambos términos coinciden en referir una acción para molestar a alguien, por lo cual son válidos para calificar conductas impropias. Acoso sexual puede definirse gramaticalmente como la acción de molestar y/o de perseguir a alguien, con motivos o intenciones sexuales, - $\mathrm{o}$ con más propiedad — de sexualidad, al identificar este término con placeres carnales. Ambos términos pueden utilizarse indistintamente; sin embargo, el de acoso sexual ha sido preferido por la legislación argentina, traducido en las lenguas inglesa y francesa como harracement y harcèlement, respectivamente.

\subsection{DEFINICIONES LEGALES}

\subsubsection{Legislación nacional:}

En la legislación argentina el acoso sexual sólo se define en las leyes que rigen el área administrativa. En Argentina el decreto presidencial número 2385 de 18 de noviembre de 1993, referido a los servidores públicos lo define como: “...el accionar del funcionario que con motivo o en ejercicio de sus funciones se aprovechare de una relación jerárquica induciendo a otro a acceder a sus requerimientos sexuales, haya o no acceso carnal".

En las provincias, únicamente existe una normativa completa conforme al derecho internacional de los Derechos Humanos al respecto en Buenos Aires. Existe un Proyecto de ley de Prevención y Sanción de la Violencia Laboral y el Acoso Sexual Laboral, con dictamen aprobado el 8/11/2011 por las Comisiones de Legislación del Trabajo y de Derechos Humanos y Garantías de la Cámara de Diputados de la Nación. 
Aunque ha sido duramente criticado por especialistas (por ejemplo, Francisco J. Abajo Olivares) por presentar errores conceptuales, no brindar procedimientos especiales de tutela y no ahondar en el ámbito público, limitando sus referencias al ámbito privado y la LCT (Ley de Contrato de Trabajo). Con respecto al Acoso sexual no lo define, y pobremente solo define la violencia laboral psicológica o mobbing, dejando de lado otras formas más amplias de violencia y maltrato laboral.

La Ley 26.485 de Protección Integral a las Mujeres (ley de protección integral para prevenir, sancionar y erradicar la violencia contra las mujeres en los ámbitos en que desarrollen sus relaciones interpersonales, Boletín Oficial de 14/4/09 y el Dec.1011/2010 reglamentario de ésta) define a la violencia sexual como "cualquier acción que implique la vulneración en todas sus formas, con o sin acceso genital, del derecho de la mujer de decidir voluntariamente acerca de su vida sexual o reproductiva a través de amenazas, coerción, uso de la fuerza o intimidación, incluyendo la violación dentro del matrimonio o de otras relaciones vinculares o de parentesco, exista o no convivencia, así como la prostitución forzada, explotación, esclavitud, acoso, abuso sexual y trata de mujeres"(art. 5.3). A su vez el art. 5 del decreto reglamentario (Dec. 1011/2010 -B.O. 20/7/2010) establece que - a los efectos de la aplicación del presente inciso deberá atenerse a lo dispuesto en el art. 2 de la Convención Interamericana para Prevenir, Sancionar y Erradicar la Violencia contra la mujer, conforme la cual la violencia contra las mujeres incluye, junto a la física y la psicológica, a la violencia sexual y se refiere tanto a las acciones o conductas que tengan lugar dentro de la familia, como a las que se produzcan en lugares de trabajo, instituciones educativas, establecimientos de salud o en otros espacios, tanto del ámbito público como del privado.

Si bien esta ley no define o tipifica en forma concreta al acoso sexual en el trabajo, prevé una concepción amplia de lo que debe entenderse por violencia sexual y no limita su ámbito de aplicación a las acciones que puedan producirse en el ambiente doméstico sino que expresamente está destinada a regular las situaciones de violencia que se verifiquen en los lugares de trabajo.

Se dispone de pocos antecedentes jurisprudenciales en los que se ha hecho aplicación de esta ley para el tratamiento de casos de acoso sexual.

La ley 26.485 además dispuso la creación del Observatorio de la Violencia contra las Mujeres en el ámbito del Consejo Nacional de la Mujer que se encuentra destinado al monitoreo, recolección, producción, registro y sistematización de datos e 
información sobre la violencia contra las mujeres. El Observatorio tiene por misión el desarrollo de un sistema de información permanente que brinde insumos para el diseño, implementación y gestión de políticas públicas tendientes a la prevención y erradicación de la violencia contra las mujeres. A la fecha límite de investigación no funciona haciendo caer en responsabilidad internacional al Estado Argentino.

\subsubsection{Legislación Internacional:}

En otros países el tema ha sido motivo de reglamentación y estudio desde hace tiempo, por lo que es conveniente analizarlas y compararlas. A continuación se señalan algunas definiciones legales:

A) La ley australiana de 1984 sobre discriminación sexual define al hostigamiento sexual como: la actitud de una persona que produce un acercamiento o hace un requerimiento sexual a otra que lo acepta al considerar que el rechazo le puede significar una desventaja en su empleo o trabajo, o puede dificultar su posibilidad de acceder a éste.

B) El código canadiense, en la División XV.I parte Tercera, lo considera como conducta, comentario, gesto o contacto de naturaleza sexual que el acosador sabe, o debería saber, que es ofensivo para la dignidad de la mujer y del hombre en el trabajo, a) por el cual se ofende o se humilla a cualquier empleado, o b) que en situaciones razonables, pudiera considerarse como una condición de orden sexual para obtener un puesto o alguna oportunidad para recibir adiestramiento o una promoción.

C) La Ley de Derechos Humanos de Canadá no define el acoso sexual pero de acuerdo a la Sección 7, se infiere como una práctica discriminatoria, cuyo contenido se amplía en la sección 14 al determinarlo, “ “... c) en materia relacionada con el empleo, perseguir a un individuo" . Este ordenamiento sanciona cuatro tipos de discriminación basada en el sexo: por género, hostigamiento en el lugar de trabajo, solicitudes sexuales, represalias sexuales.

D) En Francia existe un antecedente legislativo en el artículo L122.46 del código de trabajo, sobre el abuso de autoridad de carácter sexual en las relaciones de trabajo, núm. 92-1179 de 2 de noviembre de 1992 y la Circular núm. 93-88 de $1^{\text {o }}$ de diciembre de 1993. Esta ley dice textualmente: "Ningún trabajador puede ser sancionado ni despedido por haber sufrido o rehusado a soportar actitudes de hostigamiento de un empleador o 
de su representante o de toda persona que, abusando de la autoridad que le confieren sus funciones, haya dado órdenes, proferido amenazas, impuesto coacciones o ejercido presiones de toda naturaleza sobre su trabajador con el fin de obtener sus favores de naturaleza sexual en su provecho o en provecho de un tercero". La disposición contenida en el artículo 8o. fracciones I, II y III ha sido reformada por la Ley número 2001-397 del 9 de mayo del 2001 (Periódico Oficial del 10 de mayo del 2001), con el siguiente texto: "Ningún asalariado, candidato a reclutamiento, a una capacitación o a un periodo de formación en una empresa, puede ser sancionado, despedido o ser objeto de una medida discriminatoria, directa o indirecta, tanto en materia de remuneración, de formación, de reclasificación, de afectación, de calificación, de promoción profesional, de cambio o de renovación de contrato por haber sufrido o rehusado a padecer las acciones del acoso de un empleador, de su representante o de toda persona que, en abuso de la autoridad que le confieren sus funciones dé órdenes, amenace, imponga, coaccione o ejerza presiones de cualquier naturaleza sobre el asalariado con el fin de obtener favores de naturaleza sexual para su beneficio o en beneficio de un tercero. Ningún asalariado puede ser sancionado, despedido o ser objeto de una medida discriminatoria por haber testimoniado las acciones definidas en el párrafo precedente o por haberlos relatado". Toda disposición o todo acto contrario es nulo de pleno derecho. Es interesante que se amplíe la conducta indebida con relación a terceros, entre quienes pueden considerarse familiares, proveedores, consumidores u otros. De ahí puede establecerse que se sancione como incumplimiento contractual o se considere falta administrativa. La reforma agregó una protección para quien sea testigo del acoso sexual, lo cual es importante para la eficacia de la norma.

E) En Alemania la Ley sobre igualdad de hombres y mujeres de 24 de junio de 1994 aborda el tema y, por su parte, la legislación berlinesa admite el acoso sexual como "un contacto físico innecesario, observaciones de contenido sexual rechazados, sugestivos comentarios o bromas acerca de la personal apariencia de la persona o del cuerpo, exhibición de material pornográfico y proposiciones sexuales".

F) La ley de contrato de trabajo en Nueva Zelanda considera acoso sexual en el trabajo cuando hay proposiciones de intercambio sexual, contactos u otras formas de actividad sexual, cuyo contenido importa una propuesta de mejor trato, una amenaza de trato desfavorable, perder el empleo o adquirir un nuevo empleo, así como el uso de palabras verbales o escritas de naturaleza sexual, o conductas de tal naturaleza, que no son aceptadas por el empleado, o bien por las que éste se considera ofendido y que, por 
repetidas o por su significación, producen un efecto negativo sobre el empleo, sus condiciones de desempeño o de la propia satisfacción en el trabajo.

G) La ley número 17/88 de Puerto Rico define como acoso sexual "cualquier conducta sexual indeseada que ocurre en la relación de empleo que afecta las oportunidades, el empleo mismo, sus términos y condiciones o afecta al lugar del trabajo".

H) Además de los ya citados se observan los siguientes:

- Austria (Ley de igualdad de trato modificada por la ley número 833/1992 y la Ley federal núm. 100/1993 relativa al servicio público en general).

- Suiza (Ley federal sobre igualdad del hombre y de la mujer de 24 de marzo de 1995).

— Bélgica (Real Orden de 18 de septiembre de 1992 y de 9 de marzo de 1995).

- Costa Rica (Ley sobre el acoso sexual en el trabajo y la enseñanza, núm. 7476, de 3 de febrero de 1995).

— Estados Unidos de Norteamérica (Ley de derechos civiles de 1964).

— Filipinas (Ley en contra del acoso sexual, núm. 7877 de 8 de febrero de 1995).

- Finlandia, Ley núm. 206, de 17 de febrero de 1995 que modifica la ley sobre igualdad de 1986.

- España donde es considerado como violación al derecho a la seguridad e higiene en el trabajo.

\subsection{DEFINICIÓN DOCTRINAL}

La doctrina jurídica no ha analizado con suficiencia la problemática del acoso sexual, lo cual no es indicativo de ser una conducta libre o admitida. Quienes lucharon desde los sindicatos o personas comunes, insistieron en su penalización y sólo lograron la inclusión ambigua -lo que origina continuos debates sobre si existe o no realmenteen el Código Penal con una mención y una moderada sanción, condicionada además, a probar los perjuicios causados, lo cual es prácticamente imposible y reduce considerablemente la eficacia de la norma. De cierta manera puede interpretarse que los legisladores, en su gran mayoría varones, hayan decidido tratar el tema superficialmente para calmar ánimos, sin intención de corregir dicho desorden, tal vez sin comprender su relevancia. Es cierto que las costumbres y la idiosincrasia derivan en conceptos distintos. Las percepciones pueden cambiar de acuerdo a la cultura popular, de tal manera, que como lo señala la guía en contra del acoso sexual elaborada por la 
universidad de Australia Occidental, "algunas formas de conducta sexual que son consideradas inofensivas por alguna gente se pueden considerar ofensivas para otros". Esta universidad ha impulsado a la vez, una política en contra del hostigamiento sexual entre el personal y entre los estudiantes, entendiendo por tal, "un comportamiento inaceptable... una conducta con un componente sexual que es incómodo, no solicitado y una actitud no correspondida".

Es hasta fin del siglo $\mathrm{XX}$ que en materia laboral se registran propuestas concretas para incluirlas en la legislación. La ausencia de prohibición expresa, sin embargo, no significa que pueda quedar impune o que no existan recursos legales para protegerse.

La ausencia de doctrina, de legislación y de demandas interpuestas ante los Tribunales no significa inexistencia del problema. Ahora bien, denunciarlo o exponerlo será sencillo pero demostrarlo tiene severas complicaciones. Pareciera que el acoso sexual ha sido un tema prohibido, un problema escondido tratado siempre en la intimidad y ocultado la mayoría de las ocasiones. Ahora es justo exponerlo y abrir oportunidades para que las víctimas de esta persecución puedan defenderse, haciéndose necesario mostrarles el camino legal a seguir, algo que no es común en la práctica argentina.

La información doctrinal y la información legislativa junto con la jurisprudencia comparadas permitirán preparar la documentación y los medios de difusión convenientes, de acuerdo a las costumbres de la sociedad argentina para aplicar las medidas necesarias. Con la divulgación se cumplirá un capítulo más de los derechos de los trabajadores. Estamos de acuerdo, como lo expresan autores españoles, en que el factor principal de combate al problema responde a: la voluntad de delimitar el problema, la responsabilidad gubernamental para la creación de un entorno laboral adecuado, la puesta en marcha de diferentes recursos, legales, sindicales, que faciliten su denuncia por parte de las víctimas y su pronta solución, a ser posible en el seno de la misma institución oficial donde ocurra el hecho. Como se aprecia, existen muchas definiciones elaboradas en cada medio y en cada país. Martínez Vivot, de nuestro país, presenta varias de ellas en su libro "Acoso sexual en las relaciones laborales", que enseguida se transcriben:

A) “...conducta verbal o física, cuyo autor sabe o debería saber que es ofensiva para la víctima", entendiendo que el comportamiento es de naturaleza sexual, la cual se convierte en ilícita cuando amenace a la víctima con fundamentar decisiones dentro del 
empleo, o por el uso del poder y cuando la propia víctima entienda que dicha conducta le perjudica en su ambiente de trabajo.

B) Al citar a Husbands, menciona dos clases de acoso, el llamado chantaje sexual (quid pro quo), el tradicional, el típico, tal vez el más usual, cuya definición corresponde al del Informe Rubinstein, adoptada por el Consejo de Ministros de la Comunidad Europea, precisándolo como: " una conducta no deseada de naturaleza sexual que afecta la dignidad del hombre y de la mujer en el trabajo"; y la otra sobre el acoso sexual ambiental, término empleado en doctrina española identificado con: Incitaciones o solicitaciones sexuales importunas, o bien de otras manifestaciones verbales, no verbales o físicas de naturaleza sexual, con la finalidad o el efecto de coartar sin razón la actuación laboral de una persona o de crear un entorno de trabajo ofensivo, hostil, de intimidación o de abuso, en muchos casos para lograr que abandone el empleo.

C) A propósito de la Unión Europea, las consideraciones del derecho comunitario reflejan que el acoso sexual se define más como una cuestión de poder, que como una cuestión vulneradora de la igualdad de sexos. En el informe publicado en 1987, el Parlamento Europeo advierte además del carácter de indeseado (como lo expresa la Comisión de Oportunidades de Empleo en Estados Unidos), el carácter ofensivo, el cual debe destacarse. Expresa la resolución del Consejo de Comunidades Europeas del 29 de mayo de 1990 que deben tomarse medidas para proteger la dignidad de la mujer y del hombre. Uno de los resultados concretos es la Recomendación de la Comisión Europea para la Protección de la Dignidad de la Mujer y del Hombre en el Trabajo y el Código de Conducta para combatirlo. Al acoso sexual prácticamente se le define como "toda conducta verbal o física de connotación sexual cuyo autor sabe, o debería saber, que es ofensivo para la víctima". Es ilegal cuando el rechazo o la aceptación sea motivo para amenazar o para crear ventajas. Conviene destacar que se produjo una recomendación del Consejo de Comunidades Europeas (13-XII-1984), para tomar medidas en función del respeto a la dignidad de las mujeres en el trabajo.

D) Persecución que tiene como fundamento el trabajo en relación de dependencia con motivo o en ocasión del trabajo bajo la dirección del empleador o personal jerárquico, situación que importa una discriminación en la comunidad laboral para el trabajador que no acepta el asedio o el avance sexual y que produce o puede producir en él un cambio en las condiciones de trabajo, la cesantía o cualquier forma de menoscabo en su 
condición de ser humano y trabajador, importando a su vez una restricción a la libertad de elegir.

E) Donald B. Jarvis y Paulene C. Pasieka, de Canadá consideran difícil definir con precisión el acoso sexual; algunas conductas indeseadas, como avances sexuales o tocamientos pueden ser considerados como tal y serían actos contrarios a la Ley de Derechos Humanos, pero no toda interacción entre trabajadores, que pudieran tener algún elemento sexual se puede considerar prohibida.

F) La Universidad de Maryland, en Estados Unidos la define en relación con el ámbito de trabajo o de educación como: a) avances sexuales no deseados, requerimientos de favores sexuales no aceptados y otras conductas de naturaleza sexual, implícitas o explícitas, como una condición para emplear a una persona o para la participación en algún programa educacional o actividad de la Universidad; b) cuando tal conducta se tome en cuenta para decisiones de orden académico o de empleo afectando a una persona $\mathrm{o}$; c) cuando dicha conducta tenga el propósito o el efecto no razonable de interferir en las actividades académicas o laborales de una persona, o de crearle un ambiente laboral o escolar intimidatorio, hostil u ofensivo.

\subsection{ELEMENTOS DEL ACOSO SEXUAL EN EL TRABAJO}

La OIT (Organización Internacional del Trabajo) ha estudiado el tema del acoso sexual desde hace varias décadas. Seguramente su influencia ha permitido la exteriorización del problema y el haberlo llevado a la discusión en los ámbitos nacionales e internacional, con lo cual se facilita llegar a consideraciones de orden legal. En sus últimas publicaciones se advierten las consideraciones recogidas en distintas leyes, contratos colectivos, estudios y propuestas, que pueden recogerse como elementos del acoso sexual:

- Conducta de naturaleza sexual, y toda otra conducta basada en el sexo y que afecte a la dignidad de mujeres y hombres, que resulte ingrata, irrazonable y ofensiva para quien la recibe;

- cuando el rechazo de una persona a esa conducta, o su sumisión a ella, se emplea explícita o implícitamente como base para una decisión que afecta al trabajo de esa persona (acceso a la formación profesional o al empleo, continuidad en el empleo, promoción, salario o cualesquiera otras decisiones relativas al empleo) y,

- conducta que crea un ambiente de trabajo intimidatorio, hostil o humillante para quien la recibe. 
En términos generales pueden considerarse los siguientes elementos en el acoso sexual en el trabajo: Una acción expresa verbal o escrita. Acción que puede ser directa o indirecta. Con sentido sexual. Producción de molestia o perturbación en la persona acosada u hostigada. Creación de un ambiente hostil en detrimento de la seguridad de la persona acosada. Ámbito laboral: cuando ocurre en el desarrollo de relaciones laborales o con motivo del trabajo de la víctima.

\subsection{PROPUESTA DE DEFINICIÓN Y SANCIÓN}

Con lo expuesto hasta ahora puede proponerse una definición de acoso sexual para prohibirlo expresamente y para sancionarlo en la Ley Nacional del Trabajo y en otras leyes a futuro, el concepto que ya existe en la Ley Provincial no 12.764 de la Provincia de Buenos Aires (en el Anexo se puede ver incluso con más amplitud el proyecto original que hemos presentado ante la Honorable Cámara de Senadores de la Provincia de Buenos Aires).

\subsection{MANIFESTACIONES}

La consideración de la OIT al respecto es muy amplia. Sería difícil elaborar una relación sobre cada una de las supuestas prácticas. Los señalamientos que se hacen no pueden ni deben considerarse en forma limitativa sino enunciativa y habrá de dejarse siempre abierto un conducto para identificar el acoso sexual en apoyo de las trabajadoras o en su caso de los trabajadores.

Conforme a las recomendaciones de las comunidades europeas, la dignidad se afecta cuando la conducta es indeseada, irrazonable y ofensiva para la víctima; cuando se usa para tomar una decisión en el ámbito laboral, en la formación profesional, acceso o continuidad en el empleo, el monto salarial, en general cuando se crea un entorno laboral intimidatorio, hostil o humillante.

Por los estudios de Jane Aeberhard-Hodges se concluye que el acoso sexual en el trabajo puede adoptar distintas formas que enseguida se enumeran, a las cuales se les han agregado algunas observaciones y ejemplos:

a) Contactos físicos (se debiera agregar innecesarios), palmadas, caricias, pellizcos, roces con cualquier parte del cuerpo aun cuando aparenten ser accidentales.

Según la revista de la OIT de marzo de 1996, en los últimos años se está 
reconociendo cada vez más un tema que antes era tabú: el acoso sexual en el lugar de trabajo. Cada vez más, el problema del acoso sexual, desagradable y no deseado, está siendo abordado por los parlamentos y, ostensiblemente, por los tribunales. En un artículo publicado recientemente en la Revista Internacional del Trabajo, Jane Aeberhard-Hodges, del Servicio de Coordinación de Igualdad y Derechos Humanos de la Organización Internacional del Trabajo en Ginebra, examina las tendencias judiciales y arbitrales con respecto al acoso sexual. En su estudio, Hodges revela que la preocupación por el acoso sexual en el trabajo es reciente pero va en aumento. Hace veinte años no se reconocía como un problema, como ahora ocurre.

b) Insinuaciones sexuales, pueden ser de manera directa o indirecta, verbales o a través de expresiones, movimientos, gestos o señas, hechos con la boca, con los ojos, con las manos o cualquier parte del cuerpo; a veces hablando con terceros; mediante una canción, dichos, expresiones populares. Los gestos y otras actividades no verbales pueden ser "movimientos con el cuerpo, cabeza, brazos, manos, dedos, cara y ojos al expresar una idea, opinión o emoción. Algunos gestos intentan llamar la atención del sujeto, otros intentan provocar alguna reacción".

c) Comentarios y chistes de contenido sexual, expresados directa o indirectamente, pueden referirse tanto a la persona acosada como a otra o a un personaje imaginario.

d) Comentarios y/o chistes sobre el aspecto de la persona, de su cuerpo, peso, talla, estatura, de sus movimientos, de su vestimenta o bien de su actividad sexual o sensualidad, e igualmente cuando las expresiones se refieren a su cónyuge; lo cual podría ser común con las expresiones consideradas albures o de doble sentido.

e) Exhibición de material pornográfico, referido éste a cualquier imagen, por ejemplo en la pantalla de la computadora, una fotografía expuesta o expresamente mostrada al sujeto pasivo; dibujos, libros o revistas, proyecciones.

\subsection{CLASIFICACIÓN}

2.8.1. Por las circunstancias y actitud o comportamiento del agresor:

a) El acoso ambiental, cometido con el propósito de obtener un placer, de alcanzar los requerimientos sexuales solicitados o simplemente de molestar o perturbar. En el acoso sexual ambiental no interviene la manifestación de poder, pero se persigue importunar y coartar, sin razón, la función laboral del agredido; de crear un ambiente hostil, ofensivo, de intimidación o de abuso, muchas veces para lograr que abandone el 
empleo. En los países de habla inglesa se usa el término sex pollution, para referirse a actos que pueden conducir al acoso pero que no necesariamente lo son. Esto podría identificarse con la alusión grotesca a las condiciones de las mujeres, al referir frases despectivas, tales como son unas histéricas, cuidado con las mujeres, son unas brujas, etcétera.

b) El acoso por chantaje, cuando interviene la promesa o la simple insinuación de cualquier beneficio relacionado con la relación de trabajo, en la cual se aprovecha la subordinación de la persona acosada o, en caso contrario, se le intimida, amenaza o bien se restringen, limitan, disminuyen o impiden aumentos en los beneficios a que tiene derecho con motivo del desempeño de su trabajo. En este caso se realiza un chantaje, denominado por Martínez Vivot como "acoso sexual típico". Es acoso sexual por chantaje cuando se trata de una exigencia formulada por un superior que puede ser o no el propio empleador, de sexo masculino, a un subordinado suyo, de sexo femenino, para que se preste a una actividad sexual si quiere conseguir o conservar ciertos beneficios laborales.

En relación con este último también debe entenderse que el acoso puede ocurrir entre personas del mismo sexo, o bien provenir de sexo femenino sobre un subordinado de sexo masculino. Además que puede ocurrir entre compañeros de trabajo del mismo nivel jerárquico.

Los canadienses y norteamericanos identifican esta clase de acoso como quid pro quo sexual harassment (acoso sexual quid pro quo), en el cual son condicionantes la existencia de una relación de trabajo y el nivel superior jerárquico del sujeto activo.

En términos de la legislación argentina, no sería indispensable la subordinación laboral del sujeto pasivo. En todo caso, la aceptación o el rechazo de los requerimientos pueden producir efectos positivos o negativos.

\subsubsection{Por las consecuencias en la relación de trabajo:}

A. Consecuencias positivas al acceder o aceptar las propuestas:

a) Obtención de prestaciones (derecho de pernada).

b) Aumento de prestaciones.

c) Cambio benéfico en la asignación de tareas, disminución de cargas o de responsabilidades laborales. 
Los norteamericanos entienden que esta clase de acoso es una solicitud o requerimiento sexual.

B. Consecuencias negativas al rechazar el acoso sexual:

a) No obtener el empleo.

b) El despido.

c) Disminución de cualquier derecho o privilegio.

ch) Negar prestaciones.

d) Ambiente hostil.

e) Cambio negativo en la asignación de las tareas, aumento de cargas o responsabilidades laborales.

f) Valoración o calificación inapropiada en el desempeño del trabajo.

g) Transferencias de puesto o de lugar de trabajo.

Este acoso se fundamenta en la represión ejercida en contra del trabajador al no aceptar los requerimientos o favores sexuales. Bastaría considerar la propuesta de favores relacionados con las condiciones generales de trabajo, la intimidación o amenaza de modificarlas o hasta de rescindir la relación laboral.

\subsubsection{Por los sujetos:}

Son sujetos activos los autores de la conducta o comportamiento considerado acoso sexual y sujetos pasivos las víctimas de aquellos:

A. Acoso sexual en el trabajo en sentido estricto, cuando entre los sujetos activo y pasivo existe una relación de trabajo. En este, la responsabilidad del empleador es evidente e inevitable. Así se entiende también cuando el sujeto activo sea el familiar o el representante del empleador en el centro de trabajo (supervisor, jefe, pagador).

B. Acoso sexual en el trabajo, cuando entre el sujeto activo y pasivo no exista subordinación laboral. Podría considerarse como acoso entre compañeros de trabajo y extenderlo al hostigamiento proveniente de los directivos o delegados sindicales, miembros de organizaciones sindicales a las cuales pertenezcan ambos sujetos.

C. Acoso sexual en el trabajo, cometido por terceras personas:

a) Clientes o visitantes del empleador. A título de ejemplo piénsese en una secretaria que pudiera ser acosada por un cliente de un despacho $u$ oficinas de profesionistas, por los clientes o consumidores en centros de trabajo dedicados a brindar servicios como restaurantes, hoteles, bares, centros de diversión, transportación u otros.

b) Proveedores de bienes o servicios de la empresa, centro de trabajo del empleador o 
relacionados con sus actividades, entre ellos: agentes de ventas, distribuidores, personal de mantenimiento, asesores o ayudantes que no pertenecen a la misma planta de trabajo. D. Acoso sexual cometido por autoridades, cuando el sujeto activo es un servidor público entre quienes pueden considerarse a los:

a) Inspectores de trabajo (o cualquiera de sus ramas, incluso tratándose de seguridad social), procuradores, auxiliares, consultores o asesores en las dependencias de atención a los trabajadores. En este rubro pueden incluirse autoridades encargadas de otras actividades, por ejemplo, en el campo del registro de asociaciones sindicales.

b) Inspectores, supervisores $\mathrm{u}$ otros de cualquier dependencia gubernamental. En nuestro medio puede hacerse referencia a cualquier Secretaría de Estado que tenga entre sus atribuciones las de supervisión o inspección y otros organismos desconcentrados o descentralizados y en general, cualquier autoridad gubernamental.

c) Médicos, cuando pertenecen a instituciones de seguridad social o dependencias encargadas de los exámenes médicos, evaluaciones y atención a la salud en general respecto de los trabajadores.

d) Autoridades y personal de las Juntas de Conciliación y Arbitraje, cualesquiera que fueran sus funciones.

e) Autoridades del Poder Judicial.

f) Encuestadores, lectores de luz, agua, etcétera.

2.8.4. Por el sexo de los sujetos:

El acoso puede ser:
A) Heterosexual
B) Homosexual

2.8.5. De acuerdo con la jerarquía de los sujetos:

A) Acoso de superiores: Cuando el sujeto activo sea el empleador o empleadora, sus representantes, concubina, concubino o cualquier familiar y el sujeto pasivo sea el trabajador o trabajadora.

B) Acoso de subordinados: Cuando, sea un trabajador o una trabajadora quien actúe respecto del empleador o empleadora, sus representantes o de los sujetos que se mencionan en el párrafo anterior. 
2.8.6. En relación con el lugar en que se produce la conducta de acoso sexual:

Puede ser interno cuando ocurra en cualquier parte del centro de trabajo, por lo cual es relevante determinar qué se entiende por centro de trabajo, con mayor razón con la proliferación de nuevas formas de trabajar como el outsourcing y el teletrabajo y en general, con las diferentes categorías de trabajadores especiales para lo cual, los contratos y los reglamentos internos de trabajo tendrán extraordinaria utilidad.

2.8.7. En relación con el tiempo en que se produce la conducta de acoso sexual:

A) Cuando ocurra durante la jornada de trabajo ordinaria o extraordinaria.

B) Cuando ocurra durante días de trabajo, días de descanso o periodos vacacionales.

C) En periodos de suspensión de la relación de trabajo por cualquier motivo

D) Durante el curso de cualquier procedimiento que se siga por conflictos entre las partes.

Bajo las hipótesis señaladas es conveniente hacer precisiones, por una parte para limitar la evasión de responsabilidad y por la otra, para no incurrir en exageraciones que pudieran afectar la aplicación adecuada de la norma protectora y sancionadora, además de conformar una condición importante para prevenir conductas acosadoras.

\subsubsection{Por la edad de los sujetos:}

A) Cuando la conducta se da entre adultos.

B) Cuando el sujeto pasivo sea menor de 18 años de edad, y no sólo menor para los efectos de la legislación laboral, en que habrá de aumentarse la sanción considerando el agravamiento de la conducta ante el riesgo de ocasionar efectos más graves.

\subsection{RESPONSABILIDADES}

La responsabilidad de los empleadores varía de acuerdo con el tipo de acoso cometido. Es obvio que el empleador, como sujeto activo responda por su conducta en los términos señalados por las leyes. En los demás casos, la legislación del trabajo debe prever y sancionar distintas hipótesis, con independencia de las disposiciones de las leyes penales. La intención final es conminar al empleador a mantener un ambiente laboral libre de hostilidad y acoso sexual, lo cual contribuye a cumplir con medidas de seguridad para, evitar también el acoso moral y crear condiciones propias para el buen desempeño de las actividades previniendo riesgos de trabajo. En este sentido debe 
destacarse que el derecho a la salud de los trabajadores se refiere tanto al aspecto físico como mental y social.

Las medidas disciplinarias deben incluirse en los contratos de trabajo y en los reglamentos interiores, donde se marque el tipo de sanción aplicable. Las mismas recomendaciones pueden hacerse en el ámbito sindical para que los integrantes, junto con sus propias directivas establezcan medios de denuncia y sanciones, lo cual contribuiría al ejercicio democrático en la vida interna de sus organizaciones.

\subsection{EFECTOS}

\subsubsection{Efectos psicológicos y físicos en la víctima:}

El acoso daña la salud física, algunas de sus consecuencias son dolores de cabeza, cuello u otros puntos afectados generalmente por la tensión muscular que se produce por indicios de temor e inseguridad, lo que puede trascender y provocar otros padecimientos como pueden ser, los trastornos gastroduodenales, y la hipertensión. La salud psíquica se lastima por la inquietud que puede causar enojos, mal humor, depresión, ansiedad y otras consecuencias. En cuanto a la salud social es de considerarse el ambiente poco agradable en que conviven los colaboradores, empleados y en general la comunidad laboral que se forma; además de que pueden resultar afectados de manera indirecta los terceros (proveedores, distribuidores, clientes), con repercusión negativa en las relaciones humanas y en la productividad que tanto importa en estos tiempos al sector empresarial.

Las personas ofendidas por este tipo de conductas quedan expuestas a varios problemas leves o hasta graves, que pueden repercutir en la salud física como en la psíquica, y cuyas consecuencias pudieran afectar la esfera doméstica, familiar o sentimental. No debe descartarse, incluso, la posibilidad de que la denuncia del acoso se revierta con una denuncia por difamación perjudicando a la propia víctima. Se ha comprobado científicamente, como lo expone la OIT, que las víctimas del acoso sexual en el trabajo padecen problemas físicos. Los síntomas detectados son: dolor de cabeza, cuello u abdomen, como probable consecuencia de la tensión nerviosa.

La depresión, la angustia, la distracción, la incertidumbre, la inseguridad y el temor. Sin embargo, el más grave de todos los efectos laborales es el abandono del trabajo o la renuncia a la relación laboral por parte del trabajador, con todo lo que ello 
representa.

\subsubsection{Repercusiones para el empleador:}

Para la empresa o centro de trabajo también existen consecuencias negativas ya que el estímulo y el rendimiento de la persona ofendida disminuyen en cantidad y en calidad, haciendo aumentar los riesgos de trabajo, así como el ausentismo y el tortuguismo. Es importante reconocer que los efectos nocivos causan perjuicios en el propio centro de trabajo, alteran la disciplina y disminuyen la productividad; pero resaltaría como más grave el incremento en la incidencia de riesgos de trabajo.

\subsection{MEDIDAS}

Una de las medidas oportunas para prevenir, sancionar y erradicar el acoso sexual laboral reside en la información a todos los trabajadores sobre el significado de acoso sexual, lo nocivo de éste y sus repercusiones, haciendo amplias referencias y explicaciones que les permitan identificar cuándo una conducta, un comportamiento o una manifestación altera sus derechos laborales y encaja en lo prohibido y lo sancionable.

Para completar las medidas correspondientes y obtener resultados positivos tanto en la prevención como en el combate a estas actitudes, la información debe ser clara y concreta, valerse de lenguaje sencillo y determinar conceptos; explicar los tipos de acoso, las distintas formas de acción; señalar ejemplos y destacar las posibles formas de responder al agresor; el procedimiento inmediato o posterior que debe seguirse; a quiénes se debe recurrir en el trabajo según que el agresor sea un superior o si depende de éste, o cuando se trata de un compañero, de un subalterno o de un tercero; finalmente deben señalarse las autoridades competentes para conocer de la violación a los derechos laborales, específicamente en el acoso sexual en el trabajo. Cuando la conducta de acoso proviene de un funcionario o servidor público existe también la posibilidad legal de recurrir a las Comisiones de Derechos Humanos, que si bien no están facultadas para atender problemas laborales, sí lo están para atender asuntos de orden administrativo, como pudiera ser el caso. Igualmente, existe la posibilidad de presentar una reclamación o queja ante el Instituto Nacional contra la Discriminación o al Consejo Nacional de la Mujer en los términos que la ley de la materia señale.

La importancia en divulgar los derechos y las prestaciones de trabajo redunda en la seguridad que se de a los trabajadores acerca de sus derechos y las garantías en el 
cumplimiento de las leyes; de la defensa legal que puede ejercitar, de la asesoría gratuita, de los medios de prueba que pueden obtener o recabar para que en caso de litigio existan evidencias, elementos probatorios que permitan a las autoridades dictar resoluciones justas y no relegar la importancia de la dignidad humana.

En la práctica laboral argentina el acoso sexual es más frecuente de lo que se supone; sin embargo, no se registran rescisiones de las relaciones de trabajo o demandas laborales basadas en este tipo de discriminación, tampoco las hay para exigir igualdad y buen trato o para reclamar conductas reprobables de los superiores. Es presumible que estas circunstancias obedezcan a la falta de instrucción e información de los trabajadores, además del temor al despido como represalia, sobre todo cuando los índices de desempleo son desalentadores y no existe la certeza de recibir el pago de la indemnización correspondiente cuando se demanda la rescisión con estos fundamentos legales.

Falta destacar que la mujer resulta más vulnerable en esta problemática, ejercida principalmente por varones. Su silenciosa actitud frente a las autoridades obedece a múltiples circunstancias. La mujer asediada, por regla general, evita cualquier manifestación que pudiera provocar conflictos familiares, tales como enfrentamientos entre el esposo, compañero, o pareja, con el acosador, sea éste un compañero de trabajo, un compañero del sindicato, un superior o su empleador directamente. El silencio también obedece a la humillación y vergüenza, sentimientos que la llevan al secreto, pero que lamentablemente dejan sin sancionar al hostigador. Igual puede ocurrir en caso de que el acosado sea del sexo masculino. Cuando el acoso sexual es entre personas del mismo sexo, se presume sea más difícil el ánimo de denuncia temiendo la vergüenza, la burla, el sentimiento de crear una fama equívoca sobre sus preferencias sexuales y la humillación.

Los sindicatos por su parte deben tomar la iniciativa y responder, en defensa de los intereses de sus agremiados con el planteamiento de políticas empresariales y medidas preventivas, con la exigencia de incluirlos en las contrataciones colectivas y en los reglamentos interiores de trabajo.

\subsection{PROCEDIMIENTOS APLICABLES}

Los procedimientos aplicables a las quejas por acoso sexual y de un modo más 
general, de discriminación basada en el sexo figuran casi siempre en normas legales relativas a la igualdad de oportunidades. En algunos casos se ha creado una comisión especial para la Igualdad de Oportunidades o una comisión o consejo de Derechos Humanos, facultado para recibir quejas de acoso sexual y determinar si están justificadas o no. El modo de tramitar las quejas varía mucho pero hay ciertos elementos comunes. El procedimiento consiste análogamente en la presentación de una queja por escrito a esa entidad especial u organismo, se procede luego al estudio de la queja. El organismo investigador procura determinar si la demanda justifica que se incoe un procedimiento en materia de hostigamiento sexual. Así el investigador intenta igualmente cerciorarse de que el acto fue rechazado, de igual modo determinar la índole exacta de la relación de la persona demandante con el supuesto hostigador. Si llega a la conclusión de que la queja tiene fundamento, tomará normalmente una iniciativa de conciliación entre las partes. En algunos casos, el organismo principal se ocupa de velar por el cumplimiento de las leyes sobre los Derechos Humanos o la Igualdad de Oportunidades y falla sobre la demanda en una audiencia administrativa, mientras que en otros se lleva directamente la queja ante un tribunal ordinario o ante el tribunal de trabajo competente. El procedimiento de tramitación de las quejas con arreglo al Derecho Laboral, para lo cual es conveniente citar como ejemplo la legislación Neozelandesa, que cuenta con procedimientos especiales como el de la solución de las quejas por agravios personales contra un empleador, por el cual se presenta queja al empleador, quien debe investigar rápida y plenamente los hechos y tomar medidas prácticas que se requieran para subsanar la situación, cuando resulte que la queja está justificada. Cuando no proceda que la persona querellante intente reparar ella misma el agravio, podrá nombrar a un representante, por ejemplo un sindicato o negociador. De no quedar zanjado después de haber entrado en contacto con el empleador, el trabajador redactará una demanda indicando el tipo de agravio y la reparación que se solicita. Finalmente, en caso de no resolverse de este modo puede disponer el asunto al Tribunal del Trabajo con fines de obtener una decisión judicial. Con arreglo al Derecho Civil, los procedimientos son los mismos que en cualquier demanda civil y por tanto se someten a los tribunales ordinarios. El Derecho Penal, deja a la discreción del fiscal la decisión de si procede o no incoar un proceso penal contra el presunto autor de un acto de hostigamiento sexual. De ahí que, con la salvedad del Reino Unido, donde sigue siendo posible la acusación privada, el demandante tendrá que convencer al fiscal de que existen motivos que justifiquen que se entable un procedimiento penal contra el 
presunto hostigador.

\subsection{INFORME “Acoso sexual en el lugar de trabajo”, POR LA OIT.}

\subsubsection{Estadísticas claves}

- Una encuesta publicada en Hong Kong en febrero de 2007 mostraba que cerca del 25 por ciento de los trabajadores entrevistados sufría acoso sexual, de los cuales un tercio eran hombres. Entre los varones, sólo el 6,6 por ciento denunció su situación (en comparación al 20 por ciento de las mujeres) por miedo a hacer el ridículo.

- Según un estudio publicado en 2004 en Italia, el 55,4 por ciento de las mujeres entre 14 y 59 años declararon haber sido víctimas de acoso sexual. Una de cada tres trabajadoras sufren intimidaciones para progresar en la profesión, con el 65 por ciento de acusaciones de chantaje semanal por parte del mismo acosador, generalmente un compañero o supervisor. Asimismo, el 55,6 por ciento de las mujeres que sufren intimidación sexual han presentado su dimisión.

- En la Unión Europea, entre el 40 y el 50 por ciento de las mujeres han denunciado alguna forma de acoso sexual en el lugar de trabajo.

- Según una encuesta realizada por la Comisión Australiana de Igualdad de Oportunidades en 2004, el 18 por ciento de los entrevistados de edades comprendidas entre los 18 y los 64 años declararon haber sufrido acoso sexual en el lugar de trabajo. De entre ellos, el 62 por ciento sufrieron acoso físico y menos del 37 por ciento quisieron denunciar los hechos.

- La investigación muestra que el tipo de mujer más vulnerable al acoso sexual es la mujer joven, económicamente dependiente, soltera o divorciada y con status de emigrante. Respecto a los hombres, aquellos que sufren un mayor acoso son los jóvenes, homosexuales y miembros de minorías étnicas o raciales.

- El acoso sexual entre las personas del mismo sexo es reciente pero con una tendencia ascendente.

\subsubsection{Lucha y prevención del acoso sexual}

La experiencia en muchos países ha mostrado que la lucha efectiva contra el acoso sexual en el lugar de trabajo exige la combinación de un marco legal y de una mayor actuación de las Instituciones, adecuadamente financiadas, así como una mayor 
sensibilización sobre el tema. Algunos ejemplos de experiencias vividas se exponen a continuación. Varios gobiernos han adoptado disposiciones pertinentes que tratan el tema del acoso sexual en el lugar de trabajo:

Leyes sobre la criminalidad: India, Tanzania;

Códigos de trabajo: Chile, Tailandia;

Leyes sobre el acoso sexual: Brasil, Belice, Filipinas, Israel;

Leyes sobre la igualdad y la discriminación por razones de sexo: Japón, Sudáfrica;

Legislación nacional sobre derechos humanos: Canadá, Fidji, Nueva Zelanda;

Leyes sobre el medioambiente enfocadas hacia condiciones de trabajo seguras: Países

Bajos.

2.13.3. Juicios relativos al acoso sexual-ejemplos:

- En 2006, la Comisión sobre igualdad de oportunidades (EEOC) de Estados Unidos recibió 12.025 quejas de acoso sexual en el lugar de trabajo. Se ha experimentado un incremento del 100 por ciento en cinco años, de las que el 15,4 por ciento las presentan hombres. Dicha Comisión trató 11.936 acusaciones y recuperó 48,8 millones de dólares de daños de parte de las compañías en las que trabajaban los demandantes. Dichas cifras no incluyen las indemnizaciones obtenidas en los litigios.

- De acuerdo con una encuesta realizada por el Ejército de los Estados Unidos en 1999, el coste de los casos de acoso sexual en los que se veía implicados (tanto hombres como mujeres) ascendió a 250 millones de dólares. Dicho estudio incluyó los costes por pérdida de productividad, absentismo, separación, sustituciones y otros casos.

- En 2004, una mujer guardia de seguridad en Sudáfrica ganó un caso significativo de acoso sexual: era la primera vez que se responsabilizaba a un empleador por acoso sexual respecto a uno de sus empleados. La empresa fue condenada a indemnizar a la víctima por un despido injusto y por acoso sexual.

- En la India, el caso de referencia, Vishaka contra el Estado de Rajastha, llevó a una división a la hora de definir de forma legal el acoso sexual por parte del Tribunal Supremo. Anteriormente considerado como "resultado de la provocación", el acoso sexual fue definido por el juez como una violación de los derechos de la mujer. La sentencia destacó asimismo las directrices para su prevención y solución.” 


\section{Capítulo III}

Marco Jurídico, Estándares Internacionales y Obligaciones de los

Estados

\subsection{EL IDEALISMO COMO BALUARTE DE LA POSITIVIZACIÓN DE LOS DERECHOS HUMANOS PARA SU VIGENCIA Y GARANTÍAS.}

\subsubsection{Jurisdicción Supraestatal}

Interpretando con la Teoría del Idealismo, por jurisdicciones supra estatales entendemos mentar los sistemas que, por sobre los Estados, erigen una instancia en la que uno o más organismos tienen competencia en cuestiones de promoción y tutela de los derechos humanos con respecto a lo que acontece con esos derechos en la jurisdicción interna de los Estados que están sometidos a la correspondiente jurisdicción supraestatal. Es valioso todo sistema que habilita el acceso a una jurisdicción supraestatal a favor de personas o grupos particulares, y no sólo de los Estados, tanto como el que confiere a las decisiones de los organismos de una jurisdicción supraestatal la fuerza vinculante en la jurisdicción interna del Estado o de los Estados a los cuales esas decisiones se refieren. No se podría lograr con la teoría Realista porque ésta no admite jurisdicción supraestatal (por el principio de la autonomía del Estado soberano).

Nuestro objetivo aquí será mostrar la importancia de la internacionalización de los derechos con un propósito de eficacia: añadir a las normas internacionales que vinculan contractualmente, alguna jurisdicción supraestatal que con multiplicidad de alcances y variantes, pueda intervenir activamente para vigilar, defender y restaurar los derechos consagrados en los tratados o pactos en que son partes los Estados.

Sin esa eficacia, aplicada día a día en el derecho interno de los Estados, el derecho material no ve la luz y no hay protección hacia las personas. Debe darse tanto el derecho escrito como la aplicación asegurada por el Estado de sus componentes para que logre el fin supremo que es el "bienestar" de la comunidad en un Estado social y democrático.

Por ello, en lo que hace a nuestro tema, desde la óptica del Idealismo, veremos cuál es la protección interna y si se cumple o no la eficacia estatal y porqué motivos, llegando o procurando llegar a una conclusión sobre ella. 
Desde el punto de vista del Realismo, uno de sus intereses es la Autonomía: Es la soberanía de una nación para conducir las relaciones exteriores sin consultar con otros Estados. De este modo, el Realismo considera que por encima del Estado no existe ningún poder superior, no reconociendo organismos internacionales a los cuales someter su voluntad porque para ellos la sobrevivencia del Estado es el interés primordial de toda Nación.

Argentina en los papeles, adopta la Teoría Idealista, así la vemos reflejada en el Art. 75 inc. 22 Constitución Nacional (C.N), cuando sostiene: “... 22. Aprobar o desechar tratados concluidos con las demás naciones y con las organizaciones internacionales y los concordatos con la Santa Sede. Los tratados y concordatos tienen jerarquía superior a las leyes. La Declaración Americana de los Derechos y Deberes del Hombre; la Declaración Universal de Derechos Humanos; la Convención Americana sobre Derechos Humanos; el Pacto Internacional de Derechos Económicos, Sociales y Culturales; el Pacto Internacional de Derechos Civiles y Políticos y su Protocolo Facultativo; la Convención sobre la Prevención y la Sanción del Delito de Genocidio; la Convención Internacional sobre la Eliminación de todas las Formas de Discriminación Racial; la Convención sobre la Eliminación de todas las Formas de Discriminación contra la Mujer; la Convención contra la Tortura y otros Tratos o Penas Crueles, Inhumanos o Degradantes; la Convención sobre los Derechos del Niño; en las condiciones de su vigencia, tienen jerarquía constitucional, no derogan artículo alguno de la primera parte de esta Constitución y deben entenderse complementarios de los derechos y garantías por ella reconocidos. Sólo podrán ser denunciados, en su caso, por el Poder Ejecutivo nacional, previa aprobación de las dos terceras partes de la totalidad de los miembros de cada Cámara. Los demás tratados y convenciones sobre derechos humanos, luego de ser aprobados por el Congreso, requerirán del voto de las dos terceras partes de la totalidad de los miembros de cada Cámara para gozar de la jerarquía constitucional". De esta manera adopta la Jurisdicción Supraestatal. Pero en los hechos, en la aplicación, como veremos más adelante, más bien adopta la Teoría Realista.

\subsubsection{Derecho y Norma:}

Como ya explicáramos someramente en anterior capítulo, el acoso sexual constituye un fenómeno complejo y relativamente nuevo para el derecho del trabajo. Junto con otros institutos similares, también novedosos, como ser la discriminación y el 
acoso moral ("mobbing”), ha llamado la atención de los juristas, a punto tal de generar la reedición de antiguos tópicos de esta disciplina. Los autores se han venido refiriendo a este fenómeno como acto de discriminación, abuso de derecho, violación del derecho a la intimidad del trabajador o incumplimiento contractual que da lugar al despido indirecto (Hugo Roberto Mansueti, Acoso sexual en las relaciones laborales).

En este apartado, explicaremos el porqué es importante que la norma escrita tenga vigencia sociológica, ya sea que esa norma sea local o internacional, y con esto fundamentar que ante la falta de ella es responsabilidad del Estado parte firmante quien incumple así un deber marcado por el propio derecho internacional.

El ingreso de los derechos a la positividad es un reconocimiento de los mismos en su fuente o fundamento legitimadores, que a la vez significa darle vigencia sociológica en el mundo jurídico (derecho positivo).

Por ello, en materia doctrinaria sobre este tema (positividad) es que seguimos las enseñanzas de ilustres maestros (como el profesor Bidart Campos) para quien el contacto recíproco entre derecho natural y derecho positivo permite esclarecer lo que en el segundo hay de reconocimiento tanto como de carácter constitutivo de los derechos, ya que la fase de reconocimiento es la positivización o recepción de los derechos naturales del hombre en el mundo jurídico, y la fase constitutiva -sin separase en lo real de la otra- implica "constituir" (o transformar) en derechos positivos a los que, previamente el deber ser ideal del valor exige como debidos a la persona humana. En el orbe de la positividad el sujeto "está" en un derecho suyo cuando éste le ha sido ya reconocido y adjudicado positivamente en seguimiento al deber ser ideal del valor (derecho que, por supuesto, debe serle mantenido y respetado); al contrario, dentro de la misma positividad decimos que un sujeto "no está" en un derecho en el que "debe estar" cuando: a) todavía el derecho positivo no ha dado recepción a lo que el valor justicia exige respecto de determinado derecho natural (por ejemplo, si hay ausencia de repartos justos en relación con el pago del salario); b) el derecho positivo contiene en su orden normativo una norma que reconoce un derecho, pero éste se encuentra bloqueado o sin posibilidad de ejercicio en la dimensión sociológica (por ejemplo, si una Constitución consigna el derecho a prestaciones de salud, pero el Estado no habilita centros de asistencia médica para personas carentes de recursos). En el caso del inciso a) no se ha reducido el ingreso del derecho natural al mundo jurídico y el deber ser ideal no ha 
alcanzado el acompañamiento ejecutorio en la positividad pero mantiene su exigencia; en el caso del inciso $b$ ), se ha cumplido un primer tramo con la normatividad seguidora del deber ser ideal, pero la norma está trabada en su posibilidad de aplicación, y hace falta que el derecho (natural) reconocido en esa norma (en la dimensión normológica del mundo jurídico) cuente con posibilidades de ejercicio (en la dimensión sociológica) para que el titular tenga acceso a su disfrute efectivo (Bidart Campos, Germán, 1991. "Teoría general de los Derechos Humanos").

El derecho natural o valor justicia no opera por sí mismo, sino a través del obrar humano. Necesita del derecho positivo, es decir, precisa descender al mundo jurídico desde su deber ser ideal y entrar en la positividad (debe haber repartos justos realizados por hombres). Si no hubiera hombres, no habría ni derecho natural, ni exigencias dirigidas a los hombres. Las normas jurídicas que el derecho positivo formula por escrito no llevan en sí la garantía de su eficacia y aplicación; precisamente, la diferencia entre la dimensión normativa del mundo jurídico y la dimensión sociológica radica en que la primera (en la que hay nada más que normas) sólo muestra su vigencia normológica, pero a la positividad le hace falta la vigencia sociológica a través de conductas humanas que coincidan con lo que aquellas normas describen. Y para que esto ocurra hay que movilizar una serie de factores -políticos, culturales, económicos sociales, técnicos, jurídicos, etcétera- según los casos. Es decir, que ya no es posible incurrir en la ingenua creencia en la fuerza estructuradora de la norma, que daba por cierto que la realidad iba a adecuarse a la norma dócilmente, tan sólo por la propia fuerza motriz de la misma norma. Este idealismo racionalista ha perdido crédito. Advertimos con suficiente claridad que el derecho denominado positivo -o, más bien, las normas del orden normológico escrito- pueden frustrarse y caer en la inercia de los textos y el papel. La atención que se presta a la costumbre contra legem, a la desuetudo, a la ineficacia, etcétera, prueban lo dicho. No es de extrañar que el derecho natural o valor justicia, sin declinar su valencia y su exigencia, no siempre logre ingresar a la positívidad. En los dos casos, el hombre reacio hace su opción; en uno, incumple la norma jurídica; en otro, no da encarnadura positiva al valor. Pero así como la norma formulada por escrito persiste en el orden normativo con vigencia normológica mientras no es retirada normalmente de él, pese a su falta de vigencia sociológica, así la juridicidad del derecho natural o valor justicia no queda desmentida por la falta de recepción en la positividad. A escala nacional, en el primer caso, es el gobierno de ese Estado quien viola la norma internacional que ya existe y que se comprometió cumplir y 
hacer cumplir; en el segundo caso la viola cuando no adecúa su legislación interna de acuerdo a dichos compromisos y normas internacionales (Bidart Campos, 1991).

Como bien sostenemos en nuestra hipótesis, en Argentina por la completa falta de legislación específica (a nivel nacional) del tema de investigación, más allá que podría deducirse de los Tratados Internacionales (instancia donde sólo existe un instrumento de la OIT para prohibir el acoso sexual laboral, y una Convención donde se lo menciona, y Declaraciones contra la discriminación sexual siendo un fenómeno gravísimo y reconocido por varios Estados) aprobados por la legislación interna, demuestra no sólo la desprotección que sufren los ciudadanos cuando se ven afectados sus derechos en el tema del acoso sexual laboral, sino que deja entrever claramente la ineficacia -por carecer- de todo el sistema jurídico argentino. Además, la mera formulación escrita de normas jurídicas en el orden normativo no es equiparable a derecho positivo; un derecho es positivo cuando vige, cuando funciona, cuando se aplica, cuando es eficaz. La eficacia del sistema normativo es un elemento (constitutivo) del orden jurídico concreto (Bidart Campos, 1991). En Argentina, falla la eficacia en nuestro tema de investigación.

Así como no basta con hablar en teoría sino ejercer la defensa de los derechos humanos nos conduce a una toma de conciencia: no basta formular o escribir normas jurídicas de reconocimiento porque lo fundamental es que se alcance la cima de su vigencia sociológica, de su positividad: que se tenga acceso efectivo a su disfrute, a su goce, a su ejercicio por parte de todos los hombres y mujeres. El camino a ese objetivo es difícil, demanda esfuerzo y perseverancia. Es lucha por el derecho. Pero lo que no podemos perder de vista es que el "derecho" de los derechos humanos y con éste el referido al acoso sexual laboral, no será derecho positivo hasta tanto obtenga vigencia sociológica, es decir eficacia actual, en tiempo presente.

Para la validez del derecho positivo hay una fuente -que podría llamarse de legitimación---; tal fuente es el valor justicia; el derecho positivo es válido cuando es justo (pero también existe un derecho positivo injusto, que sigue siendo derecho positivo --vigente, pero inválido-). Cuando el derecho positivo no es justo, no es válido, sino inválido, aunque vigente.

Los grandes maestros que han y siguen enseñando sobre el mundo jurídico de los derechos humanos, coinciden en que si: a) la Constitución del Estado reconoce - 
explícita o implícitamente- los derechos humanos, entonces concuerda con el valor justicia; b) tanto el derecho constitucional como el infraconstitucional gozan de validez por participar del deber ser ideal del valor justicia, pero el derecho infraconstitucional, para ser válido, tiene que someterse al constitucional en cuanto la forma de producción jurídica y al contenido de la misma; c) el derecho positivo de los derechos humanos mantiene su validez (conforme a lo dicho en los incisos a) y b) precedentes) mientras es positivo, o sea, vigente y eficaz: d) cuando su vigencia sociológica se eclipsa, ya no hay positividad que preste sustento a la validez que, es cualidad del derecho positivo y requiere, como conditio sine qua non, de un mínimo de vigencia; d) extraviada la vigencia, y con ella la validez del derecho positivo de los derechos humanos, éstos no tienen ya ni vigencia ni validez (dentro del derecho positivo, o sea, no están "puestos" en él porque no vigen) pero el valor justicia o derecho natural (cuya "valencia" subsiste incólume) los sigue exigiendo como debidos desde el deber ser ideal del valor. Si bien en el orden normativo formulado por escrito hay una declaración o un reconocimiento de los derechos personales, y desaparece la validez por haberse extinguido su vigencia sociológica, hay que decir que las normas escritas subsisten en el orden normativo con vigencia normológica, y que pese a carecer de vigencia sociológica (y por ende de validez) pueden recobrar -y deben recobrar- esa vigencia sociológica, y con ella la validez, porque no habiendo desaparecido la normatividad escrita del mundo jurídico, existe el deber de asignarle vigencia sociológica (Bidart Campos, 1991; Benedetto Conforti,1995).

¿Cuándo y cómo ingresan los derechos humanos a la positividad? En el derecho positivo (vigente) "hay" o rigen los derechos humanos, porque los hombres tienen acceso a ellos, los pueden ejercer, gozar, y disfrutar, disponen de vías "tutelares", y conviven en un sistema efectivamente democrático.

Si sujeto de derecho es el titular -o sujeto activo- de derechos subjetivos (también, el sujeto pasivo, o titular de obligaciones), ello presupone que titulariza derechos que, por ser suyos, se denominan subjetivos. Los derechos humanos caben en esa categoría, sea que se los considere derechos morales, o derechos naturales, o derechos positivizados, porque se subjetivizan en el hombre.

$\mathrm{Y}$ en la postura de los Idealistas, ¿quién debe proveer a satisfacer los derechos humanos? La cobertura de las necesidades del hombre, es el Estado quien debe proveer mediante su fin natural de bien común público o bienestar general, uno de cuyos contenidos fundamentales es, precisamente, el respeto, la promoción, y la garantía de 
los derechos del hombre. A esta política emprendedora del bien común y de la remoción de obstáculos a la participación en él aluden en el derecho comparado, por ejemplo las constituciones de Italia y de España, y de algunas provincias de la República Argentina. Además, ¿cómo se cumple la obligación activamente universal, y quién la cumple, o la tiene a su cargo? Si empezamos por el final de la pregunta decimos que en los derechos por analogado, el sujeto pasivo obligado es el Estado, frente a todos los hombres de su sociedad. Y la cumple, no haciendo o dando algo a cada uno en particular y a través de una relación de alteridad personalizada con ese cada uno, sino haciendo o dando algo impersonalmente al conjunto social. ¿Qué es ese algo? El bien común. El bien común requiere que el Estado haga cosas, que sea servicial, que sea activo, diligente, gestor. Para englobar todo ese cúmulo de actividades productoras de bienes y servicios disponibles para la generalidad de los hombres que forman la sociedad, usemos un único vocablo: lo que debe hacer el Estado es promover y emprender "políticas" (he aquí el vocablo único) de bienestar sea que las tome él mismo a su cargo, sea que las estimule o las planifique (indicativamente) o las atribuya a la sociedad en su variado espectro organizacional y en sus espacios de libertad solidaria. Cuando tales políticas benefactoras se expanden en áreas como las referentes a necesidades humanas primarias (salud, vivienda, educación, economía, higiene, cultura, etcétera) los derechos por analogado (derechos "a") hallarán en disponibilidad suficiente los bienes.

Si el derecho positivo acusa y registra retrasos, la ciencia de los derechos humanos tiene que ir abriendo caminos. El hombre, cada hombre, es una realidad sustancial, singular, que tiene su fin propio; en tanto el Estado es también una realidad, pero accidental, que es y existe porque son y existen las partes que lo forman, los hombres, y que tiene un fin que, aunque "suyo" o naturalmente suyo, es de cierta forma ajeno a él porque lo debe perseguir y realizar en beneficio de las partes, y es el bien común. Es fin "del" Estado, suyo de él, pero "para" bien de la comunidad de hombres que conviven en el Estado.

El Estado tiene el papel y la función de realizar el bien común, participable por las partes que son los hombres.

\subsubsection{Obligaciones de los Estados: Sistema Internacional}


Siguiendo la teoría Idealista, se establecen en el derecho internacional de los Derechos Humanos -del cual hablaremos aquí someramente por ser la médula dentro del cual se inserta el derecho a no ser acosado sexualmente en el trabajo-, ciertas obligaciones para los Estados, entre las que se pueden mencionar las siguientes: obligación de abstenerse de cualquier acción o práctica de violencia contra la mujer; obligación de actuar con diligencia para prevenir, investigar y sancionar la violencia contra la mujer; reformar y adecuar la legislación interna en materia penal, civil y administrativa para proteger a la mujer en este campo; adoptar medidas jurídicas para conminar al agresor a abstenerse de hostigar, amenazar, dañar o poner en peligro la vida, integridad y propiedad de la víctima; establecer procedimientos legales justos y eficaces en favor de la mujer, garantizando el rápido acceso a tales procedimientos; asegurar la efectiva y rápida reparación del daño, a través del resarcimiento, la indemnización u otra forma de reparación.

Para ello los Estados deberán tomar ciertas medidas, entre las que se mencionan: el fomento de la educación y capacitación adecuada de personal en la administración de justicia, policial y demás funcionarios estatales; el suministro de servicios especializados apropiados para la atención de la mujer víctima de violencia, por medio de instituciones públicas y privadas, incluyendo servicio de refugios, servicios de orientación para la familia, y de cuidado y custodia de los hijos menores afectados por la violencia contra la mujer; el ofrecimiento de programas de rehabilitación de la mujer, y el impulso en los medios de comunicación de medidas de difusión y concientización sobre los derechos de la mujer contra la violencia.

El Estado tiene responsabilidad internacional ya sea porque las violaciones a los Derechos Humanos (DH) son cometidas por sus agentes o porque ha violado su obligación de garantizar el pleno goce de tales derechos cuando las autoridades toleran la violación de ciertos derechos, cometida por agentes estatales o grupos privados o cuando el Estado no previene, investiga, procesa y castiga a los responsables de estos hechos, quienes en la práctica quedan impunes y no responden por sus crímenes.

En relación con el problema de la impunidad, desde el punto de vista del derecho internacional de los $\mathrm{DH}$, podemos distinguir dos situaciones: aquella impunidad que es el resultado de un trabajo deficiente o negligente de las instituciones del Estado encargadas de administrar justicia y, por la otra, aquella que se produce con la connivencia o complicidad del aparato estatal. Esta última da origen al concepto de violación a los DH: el Estado, a través de sus agentes, decide violar los DH 
fundamentales de las personas que se encuentran bajo su jurisdicción, negar los hechos, impedir cualquier investigación y proteger a los autores. La gravedad de este hecho reside en que el Estado desvirtúa la naturaleza de la función que cumplen sus agentes, cuya misión, en una sociedad democrática es proteger los derechos del ciudadano y no violarlos (Vivanco, José Miguel. "Las organizaciones no gubernamentales de Derechos Humanos". Costa Rica, Instituto Interamericano de Derechos Humanos, Serie: Estudios de Derechos Humanos, Tomo I).

El problema de fondo relativo a los DH no es el de su justificación, sino el de la elaboración y puesta en funcionamiento de eficaces instrumentos y procesos de protección y promoción. El desafío que afronta la humanidad no se da en el plano filosófico de la fundamentación de los $\mathrm{DH}$ sino en el campo de la protección efectiva de los mismos. Esta tarea es responsabilidad primigenia de los Estados Nacionales. Cuando admitimos que los derechos fundamentales son derechos preestatales, afirmamos que el Estado y el derecho son medios exclusivamente creados para su tutela. La Constitución federal y los once instrumentos internacionales de $\mathrm{DH}$ no solo regulan el sistema de producción juridical del Estado, también someten el ejercicio de la potestad jurisdiccional y la función administrativa del Estado constitucional argentino. Su cumplimiento solo puede darse a través de políticas firmes y decididas, desplegadas desde el ámbito estatal (Prof. Pérez Suáres, Inés, Subsecretaría de Derechos Humanos y Sociales del Ministerio del Interior, 1997).

La incorporación de los tratados de DH a la Constitución Nacional en 1994 es en un contexto cultural de profunda crisis del derecho, ¿será un acto más de la tradicional hipocresía constitucional de nuestro país, de nuestros países, que deja existir y morir a las garantías constitucionales en el texto?. Estamos ante una profunda crisis de la legalidad como tal, que tiene que ver con la ausencia e ineficacia de controles. Esto implica una degradación de las reglas de juego constitucional, como los avances de un poder sobre otro, las quiebras del funcionamiento de un poder sobre otro. Esto sucede no solo en nuestro país y en Latinoamérica, es también una realidad europea muy fuerte. También se ha desatado una crisis interna del concepto mismo de estado de derecho. Se está ante una crisis del Estado Nacional. Porque es la necesidad de concentración de poder la que pone en crisis al estado nacional, es la necesidad de superar sus límites para ejercer políticas económicas, de cooperación, sociales, de protección del medio 
ambiente. Cualquier tipo de política necesita para desarrollarse superar la idea del Estado Nacional. Esto pone en crisis muy profunda al Derecho porque básicamente el estado de derecho está construido todavía, sobre el intento de limitación al poder del Estado nacional.

El sentido político del art. 75 de la Constitución Nacional es una invitación a recuperar el programa normativo por lo menos en una de sus dimensiones, la de ponerle límites al Estado y racionalizar el juego político de las instituciones. Mientras tengamos una dogmática procesal que habla con toda solemnidad de los trámites más absurdos, con dictados de sentencia que demandan diez, quince y hasta veinte años, regulando honorarios a abogados que gastaron miles de pesos en solventar juicios y que luego los jueces consideran que su trabajo vale menos que el valor de un par de zapatos. Mientras tengamos una dogmática constitucional a la que le cuesta ensuciarse las manos con los grandes problemas de la realidad del poder y las contradicciones fundamentales que hay entre la realidad política y el texto constitucional. Y mientras tengamos una doctrina de los derechos humanos que todavía se siente más cómoda en los foros internacionales que tocando las puertas y transitando los pasillos de los tribunales de nuestros países, no habremos puesto límites al Estado. ¿Los jueces podrán poner límites al Estado? No haber confiado en la justicia es uno de los elementos que hacen fracasar el programa normativo continental. El Poder Judicial no ha tenido un papel protagónico en la defensa de la Constitución, de la seguridad jurídica de los ciudadanos. ¿Qué ha pasado con esta enorme crisis de la seguridad jurídica de los sectores más débiles de nuestro país? El problema grave que hay en Argentina es el de la independencia judicial ¿cómo hace el poder judicial para construir poder propio? Mientras no se encare este problema, la dependencia estructural, que es la base de las dependencias concretas, va a persistir y no vamos a encontrar jamás una clase política suficientemente autolimitada como para renunciar a instrumentalizar al Poder Judicial (Prof. Dr. Binder, Alberto, Protección Internacional de los Derechos Humanos, Buenos Aires, 1999).

En materia penal en Argentina existe un entrenamiento teórico para una dogmática, para una construcción jurídica a nivel de un estado de derecho legal pero no de un estado de derecho constitucional. A partir del año 1984 algunos tribunales adoptaron la teoría del doble derecho: cada vez que se invocaba alguna norma del derecho internacional de los DH en materia penal -no siempre- se decía "eso es derecho internacional, no es derecho interno" (tomando la teoría aplicada por Gran Bretaña luego de la post Guerra para no aplicarlo a sus negros). Lo curioso que nuestros 
tribunales lo hacían para no aplicarlo a "nuestros negros", así había dos injustos uno nacional y otro internacional. Estas decisiones de esta manera, comprometen al Estado Argentino. Se está dando un fenómeno de perversión del concepto de bien jurídico. Se multiplican los tipos penales, y cuanto más tipos penales, más arbitrariedad tenemos. Así encontramos en nuestro país personas que han estado veinticinco años en condición de procesados, que no se ha conseguido de la justicia la prescripción y se tuvo que resolver la cuestión a través de la Comisión Interamericana, lo que es un adelantamiento de penas. Esto nos está mostrando hasta qué punto esta perversión de nuestro actual sistema de justicia viola los derechos humanos. Debemos aspirar a un Estado constitucional de derecho (Dr. Zaffaroni, Eugenio Raúl, Rev. Subsecretaría de DH y sociales del Ministerio del Interior).

Una de las cuestiones más importantes que existen hoy, no solo en América Latina sino también en Europa, así como en el Sistema Universal, es el problema de la aplicación interna de las decisiones de los órganos encargados de la protección de los DH y de las sentencias internacionales de los Tribunales existentes al respecto. Esta dificultad es particularmente compleja y grave por una cuestión que parece absurda, pero que se ha comprobado que existe en múltiples países, casi en todos los países, que es la resistencia innata del Poder Judicial y de los jueces a aplicar normas internacionales y tener en cuenta sentencias y decisiones internacionales.

Vamos a señalar tres cosas: una primera sobre los conceptos de eficacia y ejecución. Una segunda sobre la aplicación de las decisiones de los órganos internacionales de protección no jurisdiccionales. Y una tercera sobre la ejecución interna de las sentencias internacionales en materia de $\mathrm{DH}$, es decir, pronunciamientos de los órganos jurisdiccionales internacionales. Que un sistema de protección internacional de los DH sea eficaz significa, aplicando al caso la segunda acepción del vocablo eficacia que da el Diccionario de la Real Academia Española, que tiene capacidad para hacer efectivo el propósito o el fin que determinó su establecimiento. Por tanto, la eficacia de un sistema jurídico resulta de un juicio de valor en cuanto a que el objetivo tenido en vista para establecer este sistema se ha podido realizar o cumplir. Es decir, que el deber ser de la norma ha podido encontrar una adecuada relación con el ser de la realidad. De aquí la necesaria distinción entre los conceptos de validez y eficacia. Conceptos distintos pero no absolutamente independientes u opuestos, porque 
aunque una norma puede ser jurídicamente válida sin ser eficaz, no es posible negar que exista entre ambas calidades una cierta tensión y un relativo condicionamiento. Los órganos internacionales no jurisdiccionales se dividen en universales y regionales. También se dividen en órganos públicos y órganos integrados por expertos (clasificados por la doctrina como cuasi jurisdiccionales), siempre sin ser jurisdiccionales. Tienen una naturaleza con atisbos de jurisdiccionalidad. En cambio, otros órganos son absolutamente políticos. Por último las decisiones las dividimos en dos grandes grupos: según sean de carácter general o individuales y particulares.

En las Naciones Unidas (ONU) los órganos con competencia en DH, según el art. 55 letra $\mathrm{C}$ de la Carta, son dos: la Asamblea General y el Consejo Económico y Social. Casi todas las convenciones actuales de DH en la ONU provienen de proyectos elaborados en la Comisión (hoy Comité) de DH. De ahí pasan al Consejo Económico y Social y éste las remite a la Asamblea General. El más importante de estos órganos es la Comisión de DH. Es un órgano político y la integran los Estados no las personas. Ésta tiene una subcomisión de Protección de Minorías y Prevención de Discriminaciones. Esta subcomisión está integrada por expertos, designados por la Comisión de DH. En tercer lugar existe el Comité de Derechos Civiles y Políticos. La Comisión de DH es una Comisión del Ecosoc creada por la Carta de la ONU. El Comité de DH es un comité creado por el Pacto de Derechos Civiles y Políticos de la ONU integrado por 18 expertos. Es decir, es un comité cuasi jurisdiccional mientras que la Comisión es un órgano político integrado por Estados. El Comité de Derechos Civiles y Políticos creado por el Pacto tiene dos tipos de competencias distintas. ¿Qué pasa con las decisiones del Comité? Este estableció que vigilará el proceso de cumplimiento de sus decisiones, se pide al Estado que informe y se da un plazo para la recepción de dicha información, nunca superior a 180 días. Estableció un Relator especial cuya única función es seguir el proceso de cumplimiento de las decisiones del Comité. Actualmente el $80 \%$ de las decisiones del Comité son aceptadas y cumplidas por los Estados. Existen órganos no jurisdiccionales que emiten recomendaciones o decisiones creados por convenciones del sistema de las ONU: El Comité de la Convención sobre la Eliminación de todas las formas de Discriminación racial de 1965; el Comité de la Convención sobre todas las formas de discriminación contra la Mujer, con la existencia de un Comité que haga recomendaciones; la Convención Internacional contra el Apartheid en los Deportes de 1985; la Convención contra la Tortura de la ONU crea un Comité; la Convención sobre los derechos del Niño que también crea un Comité. Cabe mencionar también a los 
regímenes existentes en los organismos especializados de ONU. Hay dos organismos especializados en DH, la OIT encargada de la protección de los derechos laborales y sociales, creada por la Sociedad de las Naciones hoy de la ONU, y la UNESCO. El primero dicta una decisión que no es una sentencia y cuya eficacia por lo general es muy grande. Posee también un Comité. La UNESCO fue creada por Convención de 1946 en Londres, posee un órgano subsidiario del Consejo Ejecutivo que recibe denuncias, y con gran confidencialidad, tiene influencia a mediano y largo plazo en la corrección de las violaciones (ejemplo: Libertad de emisión del pensamiento, la libertad de prensa, etcétera.).

En cuanto a los sistemas regionales no jurisdiccionales: hay tres sistemas regionales nacidos de Convenciones Internacionales: el sistema europeo basado en el Tratado de Roma de 1950, diríamos que es el sistema más eficaz, es el que mejor funciona. El segundo sistema regional existente es el africano basado en la Carta Africana de Derechos de los Hombres y de los Pueblos. No hay órgano jurisdiccional, el único órgano es la Comisión Africana, no hay Corte; la Comisión sólo emite opinión y estudia las violaciones denunciadas. Este es el sistema menos eficaz.

En el sistema interamericano, existen dos órganos de contralor, la Comisión y la Corte. Hay 33 o 34 miembros -si es que Cuba se considera parte- y solo 25 ratificaron la Convención, no lo hizo E.U, Canadá y algunas islas anglófonas.

El Estado no incurre en responsabilidad internacional por incumplir con una recomendación no obligatoria ha dicho la Corte. Aunque no sean obligatorias, por un principio de buena fe, obliga al Estado tenerlas en cuenta. Si no hubiera un órgano jurisdiccional posterior el tema sería preocupante porque un alto porcentaje de los Estados no siguen las recomendaciones de la Comisión. Pero habiendo un órgano jurisdiccional al cual acudir en el caso que no se cumplan sus recomendaciones, la cuestión encuentra solución.

La Corte Internacional de Justicia principal órgano judicial de la ONU (art. 94 de la Carta) tiene una competencia genérica, no específica en materia de $\mathrm{DH}$.

Respecto a los órganos jurisdiccionales regionales, hay dos en el mundo: la Corte Europea y la Interamericana. La europea actúa a través de dos tipos de actos jurídicos distintos, sentencias y opiniones consultivas; la obligación de cumplimiento de las sentencias está prevista en el art. 53 del Tratado de Roma, el Consejo de Ministros 
vigila su ejecución. Todas sus sentencias, que son cientas, han sido cumplidas por los Estados condenados (partes), siendo Gran Bretaña el país más condenado.

La Corte Interamericana de DH creada por la Convención Americana como órgano de protección junto a la Comisión (ésta tiene competencia sobre todos los Estados miembros de la OEA) la Corte sólo tiene competencia contenciosa respecto a los Estados parte de la Convención; tiene dos tipos de competencia la consultiva y la contenciosa. Si bien el principio es que una opinión consultiva no es obligatoria, hoy en doctrina y jurisprudencia nacional, una opinión, vale y debe seguirse por el principio de "Buena fe". La Corte como órgano jurisdiccional tiene dos tipos posibles de actos: sentencias estricto sensu y las decisiones de trámite incluso las que pueda tomar el presidente (art. 68 decisión es sinónimo de sentencia). La sentencia es definitiva. La indemnización compensatoria se podrá ejecutar en el mismo país por el procedimiento de ejecución de sentencias. La Corte si no se cumplen sus fallos -hasta ahora se cumplieron todos- podrá elevar un informe a la Asamblea General con sus recomendaciones para ese infractor.

Hasta la fecha las sentencias se han cumplido internamente y la eficacia del sistema jurisdiccional americano ha funcionado bien. Lo que si son dilatorias, críticas y hay formas disimuladas de eludir el cumplimiento en algunos pocos casos (Dr. Héctor Gros Espiell, "Protección Internacional de los Derechos Humanos, Rev. Subsecretaría de DH y sociales del Ministerio del Interior).

\subsection{EL DERECHO INTERNACIONAL DE LOS DERECHOS HUMANOS. DEFINICIÓN-CARACTERES}

Como nuestro tema de investigación se inserta en el área de los derechos, específicamente en los derechos humanos, debemos dar una definición genérica sobre éstos para fundar nuestra tesis. Ya adelantamos al definir las palabras claves, su significado, y dijimos además que forma parte del Derecho Internacional Contemporáneo, es decir, del Derecho Internacional.

El 'Derecho internacional de los derechos humanos' es una rama del Derecho internacional desarrollada para promover y proteger los derechos humanos a nivel internacional, regional y nacional. Como rama del Derecho internacional, se compone de una serie de instrumentos internacionales obligatorios, en particular diversos tratados sobre derechos humanos, y de la costumbre internacional. Existen otros instrumentos internacionales de derechos humanos que, no siendo jurídicamente 
obligatorios, contribuyen a la aplicación, comprensión y desarrollo del Derecho internacional de los derechos humanos.

El Derecho Internacional de los Derechos Humanos, se hace presente desde que el Derecho Internacional Público ha incluído en su campo la cuestión de los derechos y libertades esenciales y fundamentales del hombre.

El Derecho Internacional de los Derechos Humanos es el conjunto de instrumentos internacionales (Tratados, convenios, resoluciones y declaraciones), establecidos para proteger los derechos humanos. El derecho internacional de los derechos humanos y las instituciones creadas en consecuencia, han sido las resultantes del proceso de incorporación de la temática de los derechos humanos y su protección, por parte del derecho internacional público.

Las instituciones $\mathrm{u}$ organizaciones internacionales son importantes como mecanismos de control de la aplicación del derecho mencionado. Por ello su tratamiento en el presente Capítulo y que veremos en otro apartado más adelante.

Los caracteres del derecho internacional de los derechos humanos son que se aplica a toda persona humana; en todas las circunstancias y la normatividad sólo vincula a los Estados.

Existe la razón de que el ser humano tiene por su naturaleza ciertos derechos valederos. Yace aquí la razón de que los derechos del ser humano sean a veces apodados derechos "naturales". Enseguida se comprende, por lógica ilación, que si estos derechos son naturales o propios de la naturaleza de la persona humana, revisten carácter de fundamentales, en el sentido de primarios o indispensables. La fundamentalidad coincide, de algún modo, con la inherencia a la naturaleza humana, a realzar la dignidad y la autonomía de la persona humana, para insertarla decorosamente en el marco de la convivencia social y del régimen político: "hay" derechos "humanos" porque el hombre -cada hombre y todo hombre- tiene una naturaleza en virtud de la cual "hay" exigencias que provienen del orbe del valor, a las que debe darse recepción en ese otro ámbito cultural de la vida humana, que es el mundo jurídico político.

Decir que hay "derechos humanos" o "derechos del hombre" en el contexto histórico-espiritual que es el nuestro, equivale a afirmar que existen derechos fundamentales que el hombre posee por el hecho de ser hombre, por su propia 
naturaleza y dignidad: derechos que le son inherentes, y que, lejos de nacer de una concesión de la sociedad política, han de ser por ésta consagrados y garantizados. Y allí aparece, entonces, la concepción que se denomina "ambivalencia" de los derechos: los derechos personales son ambivalentes porque "valen" (o son oponibles) frente a un doble sujeto pasivo: a) el Estado, y b) los particulares (o los otros hombres). Y, en verdad, si los derechos son del hombre, parece que, en general, no puedan ser únicamente derechos frente al Estado, sino frente a todos, erga omnes, incluidos los otros hombres. Cosa distinta es ya, en la diferenciación entre derechos y garantías, considerar que las garantías, en cuanto seguridades o medidas de protección se dan solamente frente al Estado. Dentro de la generalidad de esta definición encontramos el derecho a no sufrir el acoso sexual laboral como derecho humano.

\subsubsection{Universalidad de los Derechos Humanos:}

La universalidad de los derechos humanos no ofrece inconveniente con alguna módica corrección conceptual. Que son universales quiere significar que le son debidos al ser humano -a cada uno y a todos- en todas partes. 0 sea, en todos los Estados, pero conforme a la situación histórica, temporal, y espacial que rodea a la convivencia de esos hombres en ese Estado.

La ciencia jurídica que estudia los derechos humanos admite dos denominaciones: ciencia de los derechos humanos (o de los derechos fundamentales) y "Derecho" (como ciencia del "derecho objetivo") de los derechos humanos.

La persona humana se concibe así como un ser de eminente dignidad caracterizado por su razón y por su libertad. Y de la dignidad humana se desprenden todos los derechos en cuanto son necesarios para que el hombre desarrolle su personalidad integralmente. El "derecho a ser humano", es el derecho que engloba a todos los demás en el derecho a ser reconocido y a vivir en y con la dignidad propia de la persona humana.

\subsection{FALTA DE LEGITIMACIÓN DEL GOBIERNO ARGENTINO:}

Si decimos: reconozco que es justa la existencia del Estado, del poder, y del gobierno en este Estado del que soy parte, pero discrepo con su organización políticoconstitucional, con el modo como se ejerce el poder, y con lo que hacen -o no hacen- los titulares del poder. Aquí y en este caso yo mantengo la justificación de la existencia de mi Estado, de su poder, y de su gobierno, pero lo que estoy haciendo -en cambio-- es 
discutiendo su legitimidad. Decimos: este Estado tiene que existir, pero organizado en otra forma; este poder del Estado tiene que existir, pero debe ejercerse de otro modo: gobernantes tiene que haber; pero estos que hay no ejercen bien el poder. De ser así, la legitimidad está en entredicho, y no coincide con la justificación.

Un principio de legitimidad que es este: en sentido filosófico, o en ultimidad filosófica, la legitimidad política, tanto la del Estado en cuanto organización, como la del poder estatal como la del gobierno que lo ejerce, requiere esencialmente la vigencia sociológica de los derechos humanos en grado satisfactorio. A la inversa, su ausencia deslegitima a esa misma tríada de Estado, poder, gobierno.

No hay legitimidad en sentido de ultimidad filosófica cuando en un Estado esos derechos son desconocidos, negados, violados, carentes de vigencia sociológica. Y lo interesante es saber que la deslegitimación se produce porque faltan los presupuestos que la filosofía política nos ha ido proponiendo en torno de los seres humanos y el Estado, de la inserción del primero en el segundo, del fin estatal del bien común, etcétera.

Por ello el título precedente, ante la falta de normas específicas sobre el acoso sexual laboral a nivel nacional, y de aplicación real y efectiva de las normas contra la violencia de género y la violencia sexual contra la mujer (acoso sexual laboral), y de aquéllas normas que internacionalmente están incluídas en Tratados y Convenciones de Derechos Humanos que Argentina firmó y se comprometió a asegurar su aplicación, existe ilegitimidad en los gobernantes en el sentido filosófico dado, hasta que tenga vigencia sociológica el derecho a no padecer de acoso sexual laboral por ley nacional (tanto en el ámbito público como en el privado).

\subsection{PROMOVER LOS DERECHOS HUMANOS}

"Promover" puede ser entendido y debe serlo, como moverlos hacia adelante, impulsarlos, hacerlos accesibles en la dimensión sociológica del mundo jurídicopolítico. Estimular su disponibilidad a favor de cada titular y, de alguna manera, dar circulación a la libertad en todos los sectores y estratos de la sociedad.

El Estado debe promover los derechos para hacerlos posibles, y para erradicar todo lo que para muchos los vuelve imposibles, posibles de disfrute, e imposibles de acceso a ese disfrute. Siempre merodeamos en la dimensión sociológica, y no en las 
fórmulas normativas que pueden permanecer en letra muerta. El Estado debe omitir intromisiones, impedimentos, violaciones, e interferencias al libre ejercicio de los derechos. Y debe promover los que hacen a evitar el acoso sexual laboral, con el dictado de leyes internas que lo prohíban y garantizar su aplicación y control de su cumplimiento.

\subsection{LA VOLUNTAD DEL PODER:}

Todo el conjunto posible de predisposiciones y factores favorables que seamos capaces de pensar e imaginar, o que realmente haga presencia en una sociedad y en el sistema político, resultará esterilizado si la voluntad del poder (como se comprende, de aquellos que lo ejercen en un momento dado en calidad de gobernantes) se empecina en desconocer, o violar los derechos. De todos modos, no hay sistema de derechos humanos cuando la voluntad del poder se empeña en que no lo haya. Nuestra hipótesis contempla la falta de voluntad política o del poder de Argentina en implementar en el orden interno los estándares internacionales de derechos humanos que protegen contra el acoso sexual laboral a las mujeres.

\subsection{EL CONSTITUCIONALISMO MODERNO Y ARGENTINA}

Aquí conviene repasar qué sucede con el constitucionalismo a nivel local, para entender la óptica internacional que le dimos a la presente investigación. Podemos decir que se inicia con la Constitución de Estados Unidos (EU). Los derechos humanos no son derecho positivo por el mero hecho de estar en las normas de la Constitución formal o codificada; lo son cuando con o sin esa consignación escrita, tienen vigencia sociológica. La normativa escrita, si ésta no alcanza la eficacia y aplicación que definen a la misma vigencia sociológica, es "letra muerta" cuya pura vigencia normológica no alcanza para aseverar que "hay" derechos humanos en la positividad.

Cuando hay positividad pero falta eficacia, la normativa constitucional escrita sobre derechos del hombre no funciona (Bidart Campos, Germán, 1991. “Teoría general de los Derechos Humanos").

Desde nuestro punto de vista, ésa es la situación de Argentina en los hechos en nuestro tema de investigación, es decir más allá de la firma de Tratados Internacionales en los cuales se afirma la lucha contra la violencia de género en tan sólo uno de ellos (Convención de Belém do Pará) se menciona -sin definirlo- al acoso sexual laboral. Y no posee vigencia sociológica. 
Tenemos así un Estado abstencionista. En esta etapa se encuentra Argentina, en la escritura, y se deduce porque no posee vigencia el plexo normativo que protege contra la violencia de género y en especial contra el acoso sexual laboral.

\subsection{EL CONSTITUCIONALISMO SOCIAL Y ARGENTINA}

Si lo analizamos desde el constitucionalismo social, vemos que éste nace con la primera postguerra, con la Constitución de Querétaro, México de 1917. El desarrollo de los derechos sociales significa un avance en el camino de la igualdad de hecho. A la libertad "de" se agrega la libertad "para". Se le suma una ardua exigencia, la de que sus derechos socioeconómicos escritos en sus normas sean realmente accesibles disfrutables en un Estado de bienestar. Para lo cual la escritura es harto insuficiente, porque hacen falta políticas efectivas que permitan cumplir las obligaciones de dar y de hacer en favor de aquellos mismos derechos. Con lo que una vez más, la letra escrita no basta, porque lo fundamental es la vigencia sociológica.

Más crudamente: si no hay democracia liberal, no hay constitucionalismo social, porque éste, para ser tal, tiene que ser "demo" crático. El Estado de bienestar del constitucionalismo social tiene urgentemente que sacar esos derechos de su inscripción normativa para encarnarlos en la realidad de la vigencia sociológica. ¿No es acaso ése el trabajo que vienen haciendo los defensores de derechos humanos ante la indiferencia del sistema de justicia interna, es decir, exigir la aplicación efectiva del derecho?

Para la vigencia sociológica del derecho hace falta la disponibilidad de una vía tutelar (que si se quiere puede equipararse a la coactividad o coercibilidad); la autoridad pública como los hombres en general quedan vinculados obligatoriamente por la Constitución, lo que da pie sólido para afirmar que toda violación a ella, provenga de los poderes estatales o de los particulares (individual o colectivamente) es inconstitucional porque ofende a la supremacía (Bidart Campos, Germán, 1991. “Teoría general de los Derechos Humanos").

\subsection{FUENTES DE LOS D.H}

\subsubsection{Constitución:}


Es la fuente madre. En nuestro país se reformó en 1994 y se incorporaron en el art. 75 inc. 22 los Tratados Internacionales de Derechos Humanos cuyo valor es equiparable a la misma Constitución y superior a las Leyes Nacionales.

\subsubsection{Los Tratados Internacionales:}

El monismo unifica dos órdenes jurídicos y predica una unidad de fuentes, de forma que el derecho internacional contractual penetra e ingresa automáticamente, directamente y por sí mismo y por sí solo al derecho interno a partir de la ratificación del tratado por el Estado que se hace parte en él.

\subsubsection{La Jurisprudencia:}

La creación de derecho por los jueces es innegable para nuestro punto de vista, es susceptible de cubrir al derecho constitucional material con contenidos riquísimos en favor de los derechos humanos. A través de la interpretación, la integración y el control constitucionales con o sin Constitución escrita con o sin legislación, con o sin tratados internacionales. En muchísimos casos, la vigencia sociológica de los derechos depende o recibe auxilio poderoso de esta fuente de derecho judicial máxime cuando se la encara al nivel de las cortes supremas, o superiores tribunales, o cortes o tribunales constitucionales.

\subsection{LA INTERNACIONALIZACIÓN DE LOS DH}

Para explicar la aplicación de las normas internacionales sobre acoso sexual laboral en Argentina, debemos tener noción de cómo trabaja la incorporación a nivel local del derecho internacional.

La internacionalización de los DH da testimonio de dos cosas: a) que la comunidad internacional organizada y el derecho internacional han asumido a los derechos humanos como un contenido primordial del bien común internacional a su cargo, con lo que por los mismos derechos titularizados en virtud del derecho internacional, el hombre se convirtió en un sujeto del derecho internacional antes ausente de su escenario, y los Estados en responsables internacionalmente de sus políticas -internas y externas- en la materia; b) que la normatividad de los derechos humanos ya no es exclusiva ni reservada de los Estados, sino simultáneamente propia del derecho internacional y de sus órganos. El ser humano no se inserta directamente en la comunidad internacional, aun cuando ahora sea sujeto de derecho internacional. Se 
inserta en un Estado, y como parte de él, y dentro de su mundo jurídico, ostenta la investidura de derechos conforme al status que el derecho constitucional le reconoce, también cuando a ese derecho constitucional en cuanto es derecho interno de cada Estado, se sume actualmente el derecho internacional al que el derecho interno da recepción.

El derecho internacional de los derechos humanos opera a través del derecho interno de cada Estado. Esto no varía ni siquiera cuando una jurisdicción internacional da acceso -directo o indirecto- al ser humano lesionado en sus derechos, porque lo da conforme a dos principios: a) que la lesión sea imputable al Estado del que forma parte, y que esa lesión configure violación e incumplimiento estatales de una obligación internacional por él asumida; b) que previamente a la instancia internacional se haya agotado el recorrido posible de las vías jurisdiccionales internas.

En resumen, el status jurídico de la persona humana arraiga en el derecho constitucional propio del Estado al que ella pertenece, también en el supuesto de que ese status añada (internamente) el refuerzo protector del derecho internacional.

\subsection{VALOR EN EL DERECHO INTERNACIONAL}

Asumida la subjetividad internacional de la persona humana, se dice con razón que los derechos humanos han pasado a ser valorados como un "valor" propio en el derecho internacional, en el bien común internacional y en la comunidad internacional organizada.

Que en ese ámbito sean un valor significa que el derecho internacional los reconoce y "valora" como un valor que a él le incumbe y le compromete, o en otros términos, que son un ideal al que él debe prestar acogida para cooperar a realizarlo, y para brindarle protección a través de sus mecanismos propios, en refuerzo de su encarnadura sociológica.

Es decir, los derechos humanos en el seno de las Naciones Unidas, de la OEA y de la comunidad internacional operan con la fuerza del orden público internacional.

De aquí la importancia de su no aplicación en los Estados y su responsabilidad por ende, que marcamos ante la actitud de Argentina observada en nuestra investigación y como parte de los objetivos específicos de nuestra Tesis. 


\subsection{POLÍTICAS PÚBLICAS NACIONALES.}

En esta sección como dos de nuestros objetivos específicos hablan de ellas, nos proponemos evaluar la voluntad política de Argentina en la concreción efectiva de las garantías de protección internacional de derechos humanos a favor de las mujeres de nuestro país en materia de Acoso Sexual en el ámbito laboral de la administración pública nacional y locales. Y lo haremos analizando su actuación en la implementación o no de dichas políticas y en qué consisten las mismas y por último si han sido aplicadas, en qué medida, y cómo incidió su aplicación o no aplicación en el derecho interno, para comprobar así nuestra hipótesis.

Como veremos pronto en el Capítulo IV, no hay estadísticas que permitan inferir dicho cumplimiento efectivo. Nos valdremos pues, de informes tanto de la Comisión Nacional de la Mujer (algunos fueron elevados para su aprobación ante el Comité de Expertas de Violencia de la Organización de Estados Americanos, año 2005) como de organismos de reconocimiento internacional (CEDAW, ELA) e incluso del mismo Ministerio de Trabajo de la Nación (oficina OAVL).

En principio, debemos definir el concepto de políticas públicas nacionales, en tanto plan fijado por el Estado para atender las expectativas y necesidades de la Nación. Según Falomir lo define como el conjunto de aspiraciones que una comunidad nacional quiere alcanzar de manera colectiva; siendo las grandes realizaciones del pasado, su principal fuente de definiciones. En nuestras palabras, y según el Idealismo, lo concebimos como el plan de acción tendiente a concretar los ideales de la comunidad, su bienestar, concebidos según una cierta idea de país. Esa idea de país importa un posicionamiento internacional determinado y la asunción de un rol en el mundo. Según el Realismo, las políticas públicas de un país, es la proyección de sus capacidades estatales en función de una lectura de la realidad internacional y de un objetivo surgido de esa lectura, tendiente a concretar sus intereses nacionales. Es oportuno aclarar que el estilo de la acción internacional también es parte de esa política pública. De esa manera, el objetivo puede condicionar la presentación del Estado como un actor esencialmente conciliador y generador de consensos, o como un actor más bien confrontativo para con los poderes consolidados. Presentarse de una forma $u$ otra es una acción racional de ejecución del plan. En el caso de Argentina, se presenta como un conciliador hacia lo internacional pero confrontativo en lo interno hacia la comunidad, por no cumplir con sus obligaciones emanadas de los tratados dirigidas hacia la protección de los individuos. Para ello estudiaremos las respuestas emanadas del propio 
país ante los organismos internacionales en función de los informes a los que se comprometió a elevar para conocer el grado de cumplimiento de dichas obligaciones.

Sin embargo no dejaremos de lado la posición del gobierno de Argentina (año 2015) que sostiene como "política pública" a cumplir por el Consejo Nacional de las Mujeres, según su página web, lo siguiente: "Violencia de Género. La violencia contra las mujeres ha sido y es un tema prioritario para el Consejo.-Desde su creación ha participado activamente en la formulación y seguimiento de proyectos dedicados a esta temática. En la sanción de la Ley N $N^{\circ} 24.417$ del año 1994 sobre Protección de la Violencia Familiar realizó una serie de acciones tendientes a su consecución, y también participó en la Comisión del Ministerio de Justicia que elaboró su Decreto Reglamentario $\mathrm{N}^{\circ} 235 / 96$; realizó el seguimiento de los proyectos de ley para la reforma del Título III del Libro Segundo del Código Penal "Delitos contra la Honestidad", y mantuvo contacto con legisladores/as para la sanción de la Ley $\mathrm{N}^{\circ} 25.087$ que la modifica por "Delitos contra la integridad sexual" que recoge la mayoría de los cuestionamientos formulados por el movimiento de mujeres y el Consejo Nacional de las Mujeres, así como las Recomendaciones de la CEDAW.- Avances y desafíos en materia de prevención, asistencia y erradicación de la violencia de género: Las luchas por la igualdad de género, no son ajenas a la reivindicación de derechos en nuestra historia...Políticas de Estado contra la violencia de género: En el año 2009, nuestra presidenta asumió los desafíos y responsabilidades de atender y luchar por la eliminación de todos los tipos de violencias contra las mujeres, al promulgar la Ley $\mathrm{N}^{\circ}$ 26.485 de Protección Integral para Prevenir, Sancionar y Erradicar la Violencia contra las Mujeres en los Ámbitos en que Desarrollen sus Relaciones Interpersonales. Esta norma amplía los tipos y modalidades de violencia contra las mujeres, considerándolas no sólo una problemática privada, sino también de orden público. En este sentido, quedan establecidos como tipos de violencia: física, psicológica, sexual, económica y patrimonial, y simbólica, las cuales se pueden dar en los ámbitos doméstico, institucional, mediático, laboral, y obstétrico y contra la libertad reproductiva....A través del Consejo Nacional de Coordinación de Políticas Sociales y del Ministerio de Desarrollo Social, se firmó un convenio con el Instituto Nacional de Estadísticas y Censos para diseñar un conjunto de indicadores consensuados que den cuenta del fenómeno de violencia contra las mujeres y crear un Registro Único de Casos de 
Violencia contra la Mujer. En articulación con el Ministerio Público de la Defensa, se puso en funcionamiento la Oficina de Asesoramiento y Patrocinio Jurídico Gratuito. Se incorporó la figura del femicidio al Código Penal, se reglamentó la Ley de Prevención y Sanción contra la Trata de Personas y Asistencia a sus Víctimas.-Articulación con instituciones territoriales: Desde la implementación de la Ley $\mathrm{N}^{\circ} 26.485$ de Protección Integral para Prevenir, Sancionar y Erradicar la Violencia contra las Mujeres en los Ámbitos en que Desarrollen sus Relaciones Interpersonales, se impulsó y consiguió la adhesión y readecuación de las legislaciones locales. La enumeración de políticas públicas concretas llevadas a cabo durante estos años por el Estado Nacional, son profundizadas y fortalecidas paralelamente por el abordaje territorial que se realiza desde el Consejo Nacional de las Mujeres y que se centra en la difusión y sensibilización de la temática, en la capacitación y en la planificación estratégica de acciones conjuntas y en el fortalecimiento institucional, en articulación con organismos nacionales, provinciales y municipales, sindicatos, instituciones educativas, organizaciones y movimientos sociales.- Todos y todas somos parte de la solución: La problemática de la violencia contra las mujeres forma parte de la agenda del gobierno nacional. Pero es un desafío que necesita del compromiso social de todos y todas. Como ciudadanos y ciudadanas de nuestro país. El Consejo Nacional de las Mujeres tiene como uno de sus principales objetivos promover una transformación sociocultural basada en la plena e igualitaria participación de las mujeres en la vida social, económica y cultural para trabajar en el fortalecimiento de nuestra democracia. La pervivencia y reproducción de diferencias de trato basadas en estereotipos sexuales y relaciones de dominación son las causantes directas del uso de la violencia contra las mujeres y contribuyen a que nuestras sociedades no puedan avanzar en el desarrollo pleno de la igualdad. Las políticas implementadas tienen su impacto concreto en la vida de cada uno/a de nosotros/as; pero el desarrollo de acciones orientadas a luchar contra la violencia de género forman parte de un profundo cambio de paradigma cultural... y los cambios culturales requieren de tiempo y de un fuerte y generalizado compromiso cívico. Creemos firmemente que hoy tenemos la oportunidad de trabajar sobre temas por muchos años invisibilizados y creemos indudablemente que el tiempo de esa batalla cultural se puede acortar si se siguen impulsando políticas públicas concretas. Pero sobre todo, si todos y todas nos comprometemos para avanzar en la construcción de una vida libre de violencias. De una vida más igualitaria, más justa y más inclusiva”.

Podemos observar que no define nunca "política pública”, ni “interés nacional”, 
ni "bienestar de la comunidad" siquiera en términos de género, siendo el organismo encargado de la aplicación de la Ley contra la violencia a la mujer. Por lo tanto, no es posible deducir las políticas públicas sino de los informes que elevó Argentina a la CEDAW y demás organismos internacionales de Derechos Humanos de las Mujeres.

Las políticas públicas en materia social, en lo laboral, para decirlo más concretamente, requieren el diseño de acciones integrales aplicables desde el inicio de la educación de niñas y niños no sólo de la instrucción para inculcarles la reciprocidad en el respeto a la igualdad y a la diferencia. A través de los menores se multiplica la acción de sensibilización en las propias familias con repercusión gradual en la sociedad en general. Paralelo a esta política debe desarrollarse el marco legal conveniente e instituir estrategias concretas. La política de equidad y género es responsabilidad de la sociedad en su conjunto, debe estar educada, informada y convencida. En tanto se dan estos presupuestos, la sociedad debe ser orientada primero y coercionada, si es el caso, para actuar con apego a normas de derecho positivo que garanticen y exijan el respeto a los derechos humanos de las mujeres el respeto a las trabajadoras (Kurczyn Villalobos, Patricia, Acoso Sexual y Discriminación, Introducción, pág. 18).

\subsection{ACTUAL SITUACIÓN INSTITUCIONAL, ECONÓMICA Y SOCIAL DE} ARGENTINA

Es de público conocimiento la grave crisis por la que atraviesa actualmente nuestro país. Esta crisis económica, política y social que vimos de manera abrupta a partir del año 2001 (con el llamado corralito financiero) se inscribe en el marco de un proceso iniciado desde décadas atrás. Luego de un ciclo expansivo producido por el "Plan de Convertibilidad", (que fijó el tipo de cambio de manera estricta: un peso = un dólar), y que fue acompañado con la reestructuración del Estado, la privatización de casi todas las empresas públicas de servicios de consumo masivo, de la apertura de la economía al libre movimiento de capitales financieros, de la reducción de aranceles a la importación, de la negociación y creciente endeudamiento externo, de la flexibilización laboral, y de cambios importantes en las políticas fiscales, el país quedó fuertemente expuesto a los movimientos exógenos de la economía internacional. A partir de la crisis de 1995, iniciada en México, y ya definitivamente en 1997, el escenario económico interno comenzó a tornarse recesivo. Se constata un proceso creciente de concentración 
de la riqueza en pocas manos y, como contracara del mismo, un aumento de los índices de pobreza e indigencia y desocupación y subempleo y el deterioro de los derechos sociales, que impacta de manera directa en la situación de las mujeres.

Esta situación prevalece hoy día sin solución de continuidad, sumado a ello la inseguridad que castiga día a día, la falta de eficacia de la Administración de Justicia por los procesos que llevan más de treinta años en materia penal de procesados por crímenes contra la humanidad y los comunes que en algunos casos también trepan la cifra de quince años de duración y muchos terminan en prescripción con la consecuente impunidad de los sospechados de estafa al Estado, lavado de dinero, incluso por trata de personas, o por homicidios contra las mujeres (éstos últimos aumentan cada día) llevó a que la población dejara de creer en dicho estamento. Existe crisis de confianza hacia todos los estamentos del Estado.

Daremos unos datos sobre el organismo ejecutor de las políticas públicas en Argentina en materia de derechos humanos de la mujer, es decir, del Consejo Nacional de la Mujer (CNM), de qué organismo depende y cuáles son sus objetivos.

Según información de su propia publicidad oficial obtenida de su página por Internet el CNM tiene como objetivo "legitimar ante la sociedad la relevancia de la equidad de género para el fortalecimiento de la democracia, impulsando políticas públicas desde una perspectiva de género que contribuyan a la superación de las diversas formas de discriminación contra las mujeres, y promuevan las condiciones sociales adecuadas para garantizarles el ejercicio efectivo de sus derechos".

Como bien puede observarse, nació con el fin de ejecutar los compromisos internacionales en materia de Derechos Humanos de la Mujer. Es el brazo ejecutor del gobierno en estos temas. El CNM creado en el año 1992, ha dependido de Presidencia de la Nación hasta el año 1999, en que pasó a depender del Jefe del Gabinete de Ministros, que ejerce la administración general del país y coordina las acciones con los demás Ministerios. En gestión del gobierno hasta el año 2016, el CNM depende de la Presidencia del Consejo Nacional Coordinador de Políticas Sociales, del área de Presidencia de la Nación mediante resolución No 6 del 14 de julio de 2009.

En el ámbito del Ministerio de Relaciones Exteriores, Comercio Internacional y Culto funciona la Dirección de la Mujer. En 1995, se creó la Comisión Ad-Hoc para el Seguimiento de la Plataforma de Acción de la IV Conferencia Mundial sobre la Mujer, que es coordinada por dicha Comisión. Está integrada por representantes del Gobierno Central, de los Gobiernos Provinciales y de representantes de ONGs. Asimismo, en el 
marco de la VII Reunión Especializada de la Mujer del Mercosur (REM) se resolvió, mediante RES.04/02 de la VII Reunión realizada en Buenos Aires, en el mes de mayo del año 2002, recomendar la incorporación del enfoque de género en la elaboración de los Presupuestos Nacionales de los Estados Partes.

En tanto en el ámbito del Ministerio de Trabajo, funciona la Oficina de Asesoramiento sobre Violencia Laboral (OAVL) cuyas funciones también tienen que ver con la protección a los trabajadores contra la violencia en general y también contra el acoso sexual en el trabajo (público o privado).

\section{13 DEBER DE DEBIDA DILIGENCIA}

Hablaremos aquí de este principio como nuestra única variable independiente que establecimos en nuestra tarea investigativa, debido a que su omisión por los Estados, genera responsabilidad ante la Comunidad Internacional cuando se han suscripto Convenios o Tratados que protegen los derechos humanos fundamentales.

El principio de debida diligencia en el Derecho Internacional de los Derechos Humanos es el deber de prevenir, investigar y sancionar las violaciones a los derechos humanos. Este principio tiene una extensa trayectoria en el sistema jurídico internacional y en sus estándares sobre la responsabilidad de los Estados de prevenir, investigar, sancionar y reparar la violación a los derechos fundamentales, cuando estos son cometidos por agentes del Estado o por particulares. Conforme el derecho internacional de los derechos humanos, frente a la violación de los derechos fundamentales de una persona, los Estados tienen la obligación de investigar diligentemente los hechos, juzgar y sancionar a los responsables.

El fundamento normativo de esta obligación se desprende de la lectura armónica de las normas de derecho internacional que ordenan a los Estados respetar, proteger y cumplir los derechos humanos, junto con aquellas que consagran el derecho de las víctimas de acceso a la justicia. En este sentido, tanto el sistema interamericano como el sistema universal, han establecido que el deber de los Estados de investigar con debida diligencia constituye un pilar esencial para la protección y efectiva vigencia de los derechos enunciados en los tratados. En efecto, una investigación judicial seria permite esclarecer las circunstancias en las que ocurrieron los hechos que generan responsabilidad estatal, constituyendo un paso necesario para el conocimiento de la 
verdad por parte de los familiares de las víctimas y la sociedad, así como el castigo de los responsables y el establecimiento de medidas que prevengan la repetición de las violaciones a los derechos humanos.

En el marco del sistema regional de protección de los derechos humanos, la Corte Interamericana de Derechos Humanos (Corte IDH) ya desde su primer sentencia contenciosa en el caso Velásquez Rodríguez estableció la existencia de un deber estatal "de investigar seriamente con los medios a su alcance las violaciones que se hayan cometido dentro del ámbito de su jurisdicción a fin de identificar a los responsables, de imponerles las sanciones pertinentes y de asegurar a la víctima una adecuada reparación”. Ello en sintonía con el derecho de acceso a la administración de justicia consagrado en los artículos 1, 8 y 25 de la Convención Americana de Derechos Humanos $(\mathrm{CADH})$. Desde este primer pronunciamiento en adelante, la Corte Interamericana de Derechos Humanos (Corte IDH) ha reiterado que la falta de investigación y sanción de las violaciones a los derechos constituye un incumplimiento del Estado de la obligación de garantizar el pleno goce de los derechos de las víctimas y sus familiares. Estos estándares no son aplicables únicamente cuando los Estados, a través de sus agentes, son quienes cometen las violaciones a los derechos humanos, sino que también tiene implicancias directas en casos en que el Estado "tolere que los particulares o grupos de ellos actúen libre o impunemente en menoscabo de los derechos humanos reconocidos en la Convención".

Cuando un Estado no conduce investigaciones serias y sus esfuerzos por encontrar la verdad de los hechos y castigar a sus responsables están desde el inicio destinados a ser infructuosos, es allí donde se genera una presunción de que dichas violaciones están avaladas o consentidas por el poder público, lo que comprometería la responsabilidad internacional del Estado. Para cumplir íntegramente con el deber de diligencia en las investigaciones, éstas deben ser realizadas por todos los medios legales disponibles y orientada a la determinación de la verdad y a la persecución, captura, enjuiciamiento y eventual castigo de todos los responsables intelectuales y materiales de los hechos, especialmente cuando están o puedan estar involucrados agentes estatales. Las investigaciones deben ser oportunas, esto es, deben iniciarse de manera inmediata para impedir la pérdida de pruebas que pueden resultar fundamentales para la determinación de responsabilidades. El paso del tiempo guarda una relación directamente proporcional con la limitación, y en algunos casos, la imposibilidad, para obtener las pruebas y/o testimonios, dificultando y tornando ineficaz la práctica de 
diligencias probatorias a fin de esclarecer los hechos y determinar las eventuales responsabilidades penales.

Corresponde al Estado, a través de cada una de sus instituciones y en el marco de sus competencias, arbitrar todos los medios a su alcance, para garantizar la máxima idoneidad y ejecutoriedad en el desarrollo y propulsa de las investigaciones (Corte IDH, Caso “Juan Humberto Sánchez”, sentencia del 7 de junio de 2003, párr. 134; y caso “Trujillo Oroza. Reparaciones", sentencia del 27 de febrero de 2002, párrs. 99-101; entre otros. Corte IDH, Caso de la "Panel Blanca (Paniagua Morales y otros), párr. 76, nota 190. Si el aparato del Estado actúa de modo que tal violación quede impune y no se restablezca, en cuanto sea posible, a la víctima en la plenitud de sus derechos, puede afirmarse que ha incumplido el deber de garantizar su libre y pleno ejercicio a las personas sujetas a su jurisdicción. Corte IDH, Caso "Radilla Pacheco", sentencia del 23 de noviembre de 2009, párr. 216; Caso Kawas Fernández Vs. Honduras,Fondo, Reparaciones y Costas, sentencia del 3 de abril de 2009. Serie C No. 196, párr. 78. Corte IDH, Caso Heliodoro Portugal Vs. Panamá, Excepciones Preliminares, Fondo, Reparaciones y Costas, sentencia del 12 de agosto de 2008, párr. 144. Corte IDH. Caso Anzualdo Castro Vs. Perú, sentencia del 22 de Septiembre de 2009 párr. 135).

Ello también implica que las investigaciones sean conducidas en un plazo razonable y no se dilaten eternamente en el tiempo. En términos generales, si hubiera inactividad manifiesta en la investigación esto evidenciaría una "falta de respeto al principio de diligencia debida". En términos concretos, este último requisito también exige del Estado un protagonismo exclusivo, aunque no excluyente, en el impulso de la investigación. Lejos de ser pasiva o limitarse exclusivamente a solicitar pedidos de informes cuyos resultados no arrojarán ninguna acción del Estado, la diligencia exige que las autoridades actúen de modo oportuno, proactivo y propositivo a fin de evitar que se pierdan irremediablemente elementos probatorios por el paso del tiempo, o se demore el esclarecimiento de la verdad, la consecución de justicia o reparaciones. En muchos de los casos que llegaron a la instancia de la Corte IDH ésta ha sido enfática en imponer en las autoridades el deber de impulsar la investigación como un deber jurídico propio. La búsqueda efectiva de la verdad corresponde al Estado, y no depende estrictamente de la iniciativa procesal de la víctima, o de sus familiares o del aporte de elementos probatorios, por lo que se exige que la autoridad pública despliegue todo el aparato a su 
alcance para procurar efectivamente dilucidar la verdad de los hechos. Finalmente, si bien la Corte IDH tiene dicho que la obligación de investigar es una obligación de medios, no de resultado, también ha afirmado que aunque un Estado pueda constatar haber realizado diversas actuaciones judiciales mientras los hechos permanezcan en la impunidad - porque no han sido identificados ni sancionados mediante actos judiciales que hayan sido ejecutados- esa sola consideración en ciertos casos basta para concluir que el Estado ha violado la Convención Americana, pues no ha castigado a los autores de los correspondientes delitos. Al respecto, ha concluido la Corte IDH “...no viene al caso discutir si las personas acusadas en los procesos internos debieron o no ser absueltas. Lo importante es que, con independencia de si fueron o no ellas las responsables de los ilícitos, el Estado ha debido identificar y castigar a quienes en realidad lo fueron, y no lo hizo". El derecho de las víctimas a conocer la verdad tiene como efecto necesario que en una sociedad respetuosa de los derechos fundamentales se conozca lo ocurrido. Esta es una justa expectativa que el Estado debe satisfacer, por un lado, mediante la obligación de investigar las violaciones de derechos humanos y, por el otro, con la divulgación pública de los resultados de los procesos penales e investigativos. Esto exige del Estado la determinación procesal de los patrones de actuación conjunta y de todas las personas que de diversas formas participaron en dichas violaciones y sus correspondientes responsabilidades. En el mismo orden de ideas, además del derecho a la verdad, la justicia en los casos funciona como un elemento inhibidor de futuras transgresiones a los derechos fundamentales. La impunidad, en casos de violaciones a los derechos humanos resulta especialmente grave ya que favorece la repetición crónica de estos hechos.

La jurisprudencia del Comité de Derechos Humanos también vincula la obligación de investigar del Estado con el deber genérico de evitar que otras violaciones semejantes vuelvan a ocurrir. En el caso Arhuacos c. Colombia, el Comité afirmó: “(...) el Estado Parte tiene el deber de investigar a fondo las presuntas violaciones de derechos humanos, en particular las desapariciones forzadas de personas y las violaciones del derecho a la vida, y de encausar penalmente, juzgar y castigar a quienes sean considerados responsables de esas violaciones. Este deber es aplicable a fortiori en los casos en que los autores de esas violaciones han sido identificados", (párr. 8.8). Ejemplos: "Corte IDH. Caso de la Comunidad Moiwana Vs. Suriname, sentencia del 15 de junio de 2005, párr. 156” o también, “Corte IDH. Caso García Prieto y otros Vs. El Salvador, párr. 115, en donde, la Corte IDH ha establecido que: “(...) la falta de 
respuesta estatal es un elemento determinante al valorar si se ha dado un incumplimiento del contenido de los artículos 8.1 y 25.1 de la Convención Americana, pues tiene relación directa con el principio de efectividad que debe irradiar el desarrollo de tales investigaciones. De tal forma el Estado al recibir una denuncia penal, debe realizar una investigación seria e imparcial, pero también debe brindar en un plazo razonable una resolución que resuelva el fondo de las circunstancias que le fueron planteadas".

\subsection{EL PRINCIPIO DE DEBIDA DILIGENCIA EN CASOS DE VIOLENCIA DE GÉNERO}

El deber de investigar guarda particular intensidad e importancia según la gravedad de los delitos cometidos y la naturaleza de los derechos lesionados. Específicamente en casos de violencia de género y pudiendo el acoso sexual laboral ser considerado uno de ellos, existe acuerdo en la comunidad internacional sobre la especial importancia de los estándares de debida diligencia que se habló antes. Ya el primer instrumento internacional en consagrar expresamente este deber -la Declaración de Naciones Unidas sobre la Eliminación de la Violencia contra la Mujer - establece en su artículo 4.c) que "los Estados deben proceder con la debida diligencia a fin de prevenir, investigar y, conforme a la legislación nacional, castigar todo acto de violencia contra la mujer, ya se trate de actos perpetrados por el Estado o sus particulares".

Por su parte, la Convención Interamericana para Prevenir, Sancionar y Erradicar la Violencia Contra la Mujer -o Convención de Belém do Pará- avanzó en este sentido y dispuso que la obligación de actuar con la debida diligencia adquiere una connotación especial en casos de violencia contra las mujeres. Adoptada el 9 de junio de 1994, la Convención de Belém do Pará es el primer instrumento internacional de naturaleza vinculante que se ocupa específica y nominalmente del tema de la violencia contra las mujeres, por lo que bien puede considerárselo pionero, que define a la violencia contra la mujer como "cualquier acción o conducta, basada en su género, que cause muerte, daño o sufrimiento físico, sexual o psicológico a la mujer, tanto en el ámbito de lo público como en el privado". En su artículo 2, la Convención complementa la definición y enumera, entre otros supuestos, a la violencia "que tenga lugar en la comunidad y sea perpetrada por cualquier persona, y que comprende, entre otros, violación, abuso sexual, 
tortura, tráfico de personas, prostitución forzada, secuestro y acoso sexual en el lugar de trabajo, así como en instituciones educativas, establecimientos de salud o cualquier otro lugar; y que sea perpetrada o tolerada por el Estado o sus agentes, donde sea que ocurra".

Sobre esto, la Corte Interamericana de Derechos Humanos, subrayó este especial deber de debida diligencia en los casos de violencia contra las mujeres en los siguientes términos: “...las obligaciones genéricas establecidas en los artículos 8 y 25 de la Convención Americana se complementan y refuerzan, para aquellos Estados que son Parte, con las obligaciones derivadas del tratado interamericano específico, la Convención de Belém do Pará. (...) De tal modo, ante un acto de violencia contra una mujer, resulta particularmente importante que las autoridades a cargo de la investigación la lleven adelante con determinación y eficacia, teniendo en cuenta el deber de la sociedad de rechazar la violencia contra las mujeres y las obligaciones del Estado de erradicarla y de brindar confianza a las víctimas en las instituciones estatales para su protección".

Por lo demás, esta Convención refleja una preocupación uniforme en todo el hemisferio sobre la gravedad del problema de la violencia contra las mujeres, su relación con la discriminación históricamente sufrida, y la necesidad de adoptar estrategias integrales para prevenirla, sancionarla y erradicarla. La Corte IDH ha manifestado que a pesar de que las mujeres constituyen aproximadamente la mitad de la población del hemisferio, todavía existe un limitado acceso de las mujeres a la justicia, especialmente cuando han sido víctimas de violencia y discriminación, lo cual es el resultado de este patrón de discriminación y tratamiento inferior. La Convención de Belém do Pará reconoce el vínculo crítico que existe entre el acceso de las mujeres a una adecuada protección judicial al denunciar hechos de violencia, y la eliminación del problema de la violencia y la discriminación que la perpetúa. El artículo 7 de la Convención de Belém do Pará establece las obligaciones inmediatas del Estado en casos de violencia contra las mujeres, que incluyen procedimientos, mecanismos judiciales y legislación para evitar la impunidad. A título ilustrativo, en la esfera de la administración de la justicia, establece explícitamente que los Estados deben "establecer procedimientos legales justos y eficaces para la mujer que haya sido sometida a violencia, que incluyan, entre otros, medidas de protección, un juicio oportuno y el acceso efectivo a tales procedimientos" y "establecer los mecanismos judiciales y administrativos necesarios para asegurar que la mujer objeto de violencia tenga acceso 
efectivo a resarcimiento, reparación del daño u otros medios de compensación justos y eficaces (...)".

En un caso contencioso reciente, la Corte precisó algunos elementos valiosos que resultan útiles en el examen final sobre la imputación de responsabilidad del Estado en su cumplimiento del deber de debida diligencia en casos de violencia de género. Sostuvo el deber de los Estados de adoptar medidas integrales para cumplir con debida diligencia y en particular, de contar con un adecuado marco jurídico de protección, con una aplicación efectiva del mismo, con políticas de prevención y prácticas que permitan actuar de una manera eficaz ante las denuncias. "La estrategia de prevención debe ser integral, es decir, debe prevenir los factores de riesgo y a la vez fortalecer las instituciones para que puedan proporcionar una respuesta efectiva de los casos de violencia contra la mujer. Asimismo, los Estados deben adoptar medidas preventivas en casos específicos en los que es evidente que determinadas mujeres y niñas pueden ser víctimas de violencia. Todo esto debe tomar en cuenta que en casos de violencia contra la mujer, los Estados tienen, además de las obligaciones genéricas contenidas en la Convención Americana, una obligación reforzada a partir de la Convención de Belém do Pará" (Corte IDH. Caso Anzualdo Castro Vs. Perú, Excepción Preliminar, Fondo, Reparaciones y Costas, sentencia del 22 de septiembre 2009. Serie C No. 202, párr. 119).

\subsection{DEBIDA DILIGENCIA, PREVENCIÓN Y ERRADICACIÓN DE LA VIOLENCIA Y LA DISCRIMINACIÓN}

El artículo 2 de la Convención Americana sobre Derechos Humanos establece el compromiso de los Estados de adoptar todas las medidas necesarias para llevar a la práctica los derechos consagrados en este instrumento.

El contenido y alcance de este artículo debe ser interpretado en conjunto con el deber de actuar con la debida diligencia para prevenir, investigar y sancionar la violencia contra la mujer, codificado en el artículo 7 (b) de la Convención de Belém do Pará. Debe ser interpretado asimismo con el artículo 2 de la CEDAW, el cual afirma como obligación fundamental de los Estados parte: "Establecer la protección jurídica de los derechos de la mujer sobre una base de igualdad con los del hombre y garantizar, por conducto de los tribunales nacionales competentes y de otras instituciones públicas, 
la protección efectiva de la mujer contra todo acto de discriminación".

Los Estados por consiguiente tienen el deber de ofrecer una protección judicial efectiva a mujeres víctimas de violencia, en condiciones de igualdad y libre de toda forma de discriminación. Lo mismo acontece en el caso de sufrir de acoso sexual laboral.

Un aspecto fundamental en la garantía del acceso a la justicia en condiciones de igualdad es el cumplimiento del deber de los Estados de actuar con la debida diligencia requerida frente a actos de violencia contra las mujeres. La Corte Interamericana ha afirmado que este deber comporta cuatro obligaciones: la prevención, la investigación, la sanción, y la reparación de toda violación de los derechos humanos, con el fin de prevenir la impunidad. Los sistemas internacional y regional de derechos humanos asimismo se han pronunciado sobre la estrecha relación entre la discriminación, la violencia y la debida diligencia, enfatizando que la falla del Estado de actuar con debida diligencia para proteger a las mujeres de la violencia constituye una forma de discriminación, y una negación de su derecho a la igual protección de la ley y del deber de garantizar el acceso a la justicia. La Comisión Interamericana de Derechos Humanos (CIDH) se ha pronunciado sobre el contenido del deber de actuar con la debida diligencia ante actos de violencia contra las mujeres de forma reciente, en el caso de Jessica Lenahan (Gonzales), la CIDH discutió cómo la comunidad internacional ha aplicado de forma reiterada el estándar de la debida diligencia como manera de comprender qué significan en la práctica las obligaciones de los Estados en materia de derechos humanos, cuando se trata de violencia cometida contra las mujeres de distintas edades y en distintos contextos. Este estándar también ha sido crucial para definir las circunstancias en que el Estado puede estar obligado a prevenir actos u omisiones de particulares y a responder por ellos. Este deber comprende la organización de toda la estructura estatal - incluyendo el marco legislativo, las políticas públicas, los órganos encargados de implementar la ley como la policía, y el sistema judicial - para prevenir y responder de forma adecuada y efectiva a estos problemas. Tanto la Comisión como la Corte Interamericanas han invocado el principio de la debida diligencia como referencia para pronunciarse jurídicamente sobre casos y situaciones de violencia contra la mujer perpetrada por particulares, incluyendo casos relacionados con niñas y mujeres que sufren una intersección de formas de discriminación, como las mujeres indígenas y afrodescendientes. En la evolución del derecho y de la práctica relacionada con la aplicación del estándar de la debida diligencia en casos de violencia contra la mujer 
destacan, en particular, cuatro principios: El Estado puede incurrir en responsabilidad internacional por no actuar con la debida diligencia para prevenir, investigar, sancionar y reparar los actos de violencia contra la mujer; un deber aplicable a los actos cometidos por particulares en ciertas circunstancias. En segundo lugar, existe un vínculo entre la discriminación, la violencia contra la mujer y la debida diligencia, por lo tanto, es un deber de los Estados enfrentar y responder a la violencia contra la mujer, lo que implica tomar medidas para prevenir la discriminación que perpetúa este grave problema. Los Estados deben adoptar las medidas necesarias para modificar los patrones de comportamiento sociales y culturales de hombres y mujeres, y eliminar los prejuicios y las prácticas consuetudinarias y de otra índole basadas en la premisa de la inferioridad o superioridad de uno de los sexos, y sobre los roles estereotipados que se imponen tanto a los hombres como a las mujeres.

En tercer lugar, destaca el vínculo entre el deber de actuar con la debida diligencia y la obligación de los Estados de garantizar el acceso a recursos judiciales adecuados y efectivos para las víctimas y sus familiares, cuando son objeto de actos de violencia. Cuarto, los sistemas de derechos humanos tanto a nivel internacional como regional han identificado ciertos grupos de mujeres expuestos a un riesgo particular de sufrir actos de violencia, debido a formas de discriminación que sufren por más de un factor, como las niñas y las mujeres pertenecientes a ciertos grupos étnicos, raciales y minoritarios; lo que debe ser considerado por los Estados en la adopción de medidas para prevenir todas las formas de violencia.

Si falla el Estado en dictar leyes internas que frenen el acoso sexual laboral, entonces, es discriminación hacia las víctimas.

\subsection{DEBER DE NO DISCRIMINAR Y DAR UN TRATO IGUALITARIO EN EL} ACCESO A LA JUSTICIA

La igualdad entre hombres y mujeres es una premisa sobre la que se apoyan todos los instrumentos internacionales para la protección de los derechos fundamentales de las personas. Desde la Carta de las Naciones Unidas y la Carta de la Organización de los Estados Americanos, pasando por la Declaración Universal de los Derechos Humanos, la Declaración Americana de los Derechos y Deberes del Hombre, el Pacto Internacional de Derechos Civiles y Políticos y la Convención Americana sobre 
Derechos Humanos, por mencionar sólo algunos, se ha afirmado la igualdad de toda persona ante la ley sin distinciones de ningún tipo. Todos estos documentos han robustecido este derecho disponiendo, además, la prohibición de discriminar por parte del Estado y sus agencias. En la Convención sobre la Eliminación de todas las Formas de Discriminación contra la Mujer se establecen una serie de obligaciones en cabeza de los Estados Parte para garantizar que las mujeres gocen de sus derechos en igualdad de condiciones que los hombres y define la discriminación contra la mujer como "toda distinción, exclusión o restricción basada en el sexo que tenga por objeto o por resultado menoscabar o anular el reconocimiento, goce o ejercicio por la mujer, independientemente de su estado civil, sobre la base de la igualdad del hombre y de la mujer, de los derechos humanos y las libertades fundamentales" en cualquier ámbito.

El fenómeno de la violencia contra la mujer constituye una manifestación de relaciones de poder históricamente desiguales entre la mujer y el hombre, que han conducido a la dominación de la primera y a la discriminación en su contra por parte del hombre e impedido el adelanto pleno de la mujer. Es por ello que se identifica a la violencia basada en género como una de las formas más extremas y generalizadas de discriminación, que nulifica el ejercicio de los derechos de las mujeres. En este sentido, la violencia contra las mujeres es también resultado de la discriminación de género que determina la estructura histórica social, económica, cultural y política. Si bien la violencia de género en sus distintas expresiones es un fenómeno extendido y arraigado en las sociedades latinoamericanas, la respuesta de la justicia para combatirlo es aún ineficiente. Precisamente, la $\mathrm{CIDH}$ ha interpretado esto último como el resultado de la discriminación históricamente sufrida por las mujeres en este hemisferio (Véase, por ejemplo, Resolución de la Asamblea General de las Naciones Unidas, Consejo de Derechos Humanos, Acelerar los esfuerzos para eliminar todas las formas de violencia contra la mujer: garantizar la diligencia debida en la prevención, A/HRC/14/L.9/Rev.1, 16 de junio de 2010).

\subsection{LA IMPUNIDAD EN LOS CASOS DE VIOLENCIA CONTRA LA MUJER}

La gran importancia con que se ha enunciado el deber de debida diligencia en los casos de violencia de género -reiteramos, aplicable al acoso sexual- se contrapone con los bajos índices de persecución y juzgamiento que se registran históricamente en los casos de violación a los derechos humanos de las mujeres en Argentina y en la región americana. Esto es especialmente importante a la hora de analizar y decidir casos 
que lejos de constituir hechos aislados forman parte de un patrón de impunidad sistemática en el procesamiento judicial y en las actuaciones relacionadas con casos de violencia contra las mujeres.

A este respecto, la Corte IDH ha llamado la atención sobre la impunidad de los delitos cometidos en los casos específicos de violencia de género, en el entendimiento de que "envía el mensaje equivocado de que la violencia contra la mujer es tolerada, lo que favorece su perpetuación y la aceptación social del fenómeno, el sentimiento y la sensación de inseguridad en las mujeres, así como una persistente desconfianza de éstas en el sistema de administración de justicia”. Para ilustrar estas conductas, la Comisión IDH, en un Informe sobre Acceso a la Justicia para Mujeres Víctimas de Violencia en las Américas advirtió que "ciertos patrones socioculturales discriminatorios influyen en las actuaciones de los funcionarios en todos los niveles de la rama judicial, lo que se traduce en un número aún ínfimo de juicios orales y sentencias condenatorias que no corresponden al número elevado de denuncias y a la prevalencia del problema. La Comisión IDH ha podido verificar que la violencia y la discriminación contra las mujeres todavía son hechos aceptados en las sociedades americanas, lo cual se ve reflejado en la respuesta de los funcionarios de la administración de la justicia hacia las mujeres víctimas de violencia y en el tratamiento de los casos" (Comisión IDH, "Acceso a la Justicia para Mujeres Víctimas de Violencia en las Américas”, 20 de enero de 2007, punto I.B.32; en un sentido similar ver: CIDH, Informe Actualizado sobre la Labor de la Relatoría sobre los Derechos de la Mujer, OEA, 16 de abril de 2002, párr. 42 y 43$)$.

La Corte IDH (Corte IDH, caso "González y Otras (Campo Algodonero) vs. México”, párr. 400) y la Comisión IDH (CIDH, “Acceso a la Justicia...”, punto II.A.2, párr. 147) han insistido en que las investigaciones por violaciones a los derechos humanos deben ser emprendidas por autoridades competentes e imparciales. En los casos de violencia contra las mujeres, este deber adquiere una especial connotación, esto es, que los operadores judiciales y policiales hayan sido formados con un enfoque género-sensitivo que les permita abordar estos casos libres de prejuicios y estereotipos. Esta formación implica, en primer lugar, que puedan reconocer los estereotipos de género que desvalorizan a las mujeres y sus vivencias, y que inciden directamente en el modo en que las agencias judiciales responden -ineficientemente- en casos de violencia 
de género. También comprende la capacidad de advertir la situación de vulnerabilidad en la que se encuentran las mujeres víctimas de violencia y la gravedad y generalidad de las distintas expresiones de este problema. En este sentido, la $\mathrm{CIDH}$ ha dicho que "Cuando tales investigaciones no son llevadas a cabo por autoridades apropiadas y sensibilizadas en materia de género (...), se registran retrasos o vacíos clave en las investigaciones, que afectan negativamente el futuro procesal del caso".

La Corte IDH hizo propias estas líneas en su reciente decisión en el caso “Campo Algodonero", incluso ensayó una definición de los prejuicios que pueden afectar la labor de las agencias del Estado: “...el estereotipo de género se refiere a una pre-concepción de atributos o características poseídas o papeles que son o deberían ser ejecutados por hombres y mujeres respectivamente. (...), es posible asociar la subordinación de la mujer a prácticas basadas en estereotipos de género socialmente dominantes y socialmente persistentes, condiciones que se agravan cuando los estereotipos se reflejan, implícita o explícitamente, en políticas y prácticas, particularmente en el razonamiento y el lenguaje de las autoridades de policía judicial (...). La creación y uso de estereotipos se convierte en una de las causas y consecuencias de la violencia de género en contra de la mujer". En este caso, la existencia de estos prejuicios en las autoridades competentes que debían investigar y sancionar las graves violaciones a los derechos de las mujeres que se registraban en Ciudad Juárez, implicó la responsabilidad del Estado mexicano por violación a la prohibición de discriminación del art. 1.1 de la Convención Americana. Tanto en este como en otros precedentes, la Corte IDH ha dicho expresamente que los crímenes contra las mujeres deben ser investigados y juzgados con perspectiva de género.

Argentina ha recibido indicaciones concretas en este sentido por parte del Comité para la Eliminación de la Discriminación contra la Mujer (CEDAW). En sus Recomendaciones Finales efectuadas el 30 de julio de 2010, el Comité expresó su fuerte preocupación por "los estereotipos de género imperantes en el sistema de justicia y su desconocimiento de la discriminación por motivos de sexo y de género, así como de la violencia contra la mujer". Luego de ello, reclamó al Estado argentino que velara para que "la judicatura, incluidos jueces, abogados, fiscales y defensores públicos, conozca los derechos de la mujer y las obligaciones del Estado parte con arreglo a la Convención, y alienta a este a que imparta capacitación sobre cuestiones de género a todos los miembros del sistema de justicia, entre ellos los organismos encargados de hacer cumplir la ley, y a que vigile los resultados de esa labor. Esto precisamente se 
vincula con el desconocimiento que evidencian los funcionarios judiciales acerca de las normas del derecho internacional que resultan de cumplimiento obligatorio para el Estado, en los casos de violencia de género.

\subsection{OBLIGACIÓN DE LOS ESTADOS Y DERECHO A LA INFORMACIÓN COMO DERECHO INSTRUMENTAL CONTRA LA VIOLENCIA Y LA DISCRIMINACIÓN A LA MUJER.}

Aquí hablaremos de un derecho específico que ayuda a proteger a la mujer contra la violencia, incluída como vengo sustentando desde el inicio, el acoso sexual laboral como forma de violencia, y es el derecho de acceso a la información el que genera una serie de obligaciones específicas para los Estados. Y es importante este apartado, porque en el país se deben tener estadísticas sobre el avance de la implementación de las leyes de derechos humanos, conocer cantidad de casos, denuncias y sus resultados, juicios, investigación, elementos para su comprobación, etcétera. Y cómo son las políticas públicas al respecto, todo manifestado en organismos estatales transparentes encargados de la información tanto a la ciudadanía, como a los organismos internacionales sobre el cumplimiento de los Tratados firmados. Establezcamos primero las obligaciones para comprender pues, así, uno de los fundamentos de la tesis, y que respondería a gran parte de los objetivos específicos que nos propusimos, y respecto de los cuales no se han podido concretar del modo propuesto originariamente (por estadísticas) por la inexistencia de información y/o su ocultamiento.

A juicio de la CIDH, el acceso a la información en su dimensión de derecho instrumental para el ejercicio efectivo de los derechos de las mujeres a vivir libres de discriminación y violencia supone la observancia de tres obligaciones principales por los Estados: (i) la obligación de recolectar y producir información, (ii) la obligación de transparencia activa y (iii) la obligación de responder de manera oportuna las solicitudes de acceso a la información y garantizar un recurso efectivo que permita la satisfacción del derecho. Estas obligaciones se examinan a continuación.

a) LA OBLIGACIÓN DE RECOLECTAR Y PRODUCIR INFORMACIÓN. 
En general, a partir del principio de buena fe, los Estados tienen la obligación de garantizar la disponibilidad y el acceso a la información, a través de la recolección, registro o producción de aquella información que es necesaria para el cumplimiento de obligaciones internacionales, constitucionales y legales. En cumplimiento de esta obligación, los Estados tienen el deber de producir información estadística desagregada por colectivos vulnerables, y al respecto la Comisión Interamericana (CIDH) ha sostenido que "la producción de información debidamente desagregada, a efectos de determinar [los] sectores desaventajados o postergados en el ejercicio de derechos, desde esta perspectiva, no es sólo un medio para garantizar la efectividad de una política pública, sino una obligación indispensable para que el Estado pueda cumplir con su deber de brindar a estos sectores atención especial y prioritaria. A modo de ejemplo, la desagregación de los datos por sexo, raza o etnia constituye una herramienta imprescindible para iluminar problemas de desigualdad". Particularmente, en relación con el acceso a la información pública en materia de discriminación y violencia, la Convención de Belém do Pará establece que los Estados se comprometen a adoptar, en forma progresiva, un conjunto de medidas y programas que garanticen el derecho de las mujeres a un acceso adecuado, efectivo y oportuno a la justicia en casos de violencia. Tales medidas, de conformidad al artículo 8 (h) del referido instrumento, incluyen aquéllas destinadas a asegurar "la investigación y recopilación de estadísticas y demás información pertinente sobre las causas, consecuencias y frecuencia de la violencia contra la mujer, con el fin de evaluar la eficacia de las medidas para prevenir, sancionar y eliminar la violencia contra la mujer y de formular y aplicar los cambios que sean necesarios" (CIDH, El derecho de acceso a la información en el marco jurídico interamericano, Segunda Edición, Relatoría Especial para la Libertad de Expresión, 7 de marzo de 2011, párr. 35 y párr.. 36; Corte IDH. Caso Gomes Lund y otros ("Guerrilha do Araguaia") Vs. Brasil. Excepciones Preliminares, Fondo, Reparaciones y Costas, Sentencia de 24 de noviembre de 2010, Serie C No. 219, párr. 211).

Las obligaciones derivadas del artículo 8 de la Convención de Belem do Pará deben interpretarse conjuntamente con las establecidas en el artículo 7 del mismo instrumento internacional, que establece una serie de obligaciones inmediatas para el Estado tales como el actuar con la debida diligencia para prevenir, investigar y sancionar la violencia contra las mujeres. Al respecto, la $\mathrm{CIDH}$ ha sostenido expresamente que: El deber de debida diligencia para prevenir situaciones de violencia, sobre todo en el contexto de prácticas extendidas o estructurales, impone a los Estados 
el correlativo deber de vigilar la situación social mediante la producción de información estadística adecuada que permita el diseño y la evaluación de las políticas públicas, así como el control de las políticas que se implementen por parte de la sociedad civil. En tal sentido, la obligación del artículo 7 inciso B de la Convención de Belém do Pará debe ser interpretada en conjunción con la obligación establecida en el artículo 8 inciso $\mathrm{H}$ de garantizar la investigación y recopilación de estadísticas y demás información pertinente sobre las causas, consecuencias y frecuencia de la violencia contra las mujeres, con el fin de evaluar la eficacia de las medidas para prevenir, sancionar y eliminar la violencia contra las mujeres y de formular e introducir los cambios necesarios. Del mismo modo, en el marco de Naciones Unidas se ha afirmado en numerosas oportunidades la necesidad de recopilar y difundir información sobre la discriminación y la violencia contra las mujeres. En este ámbito se ha destacado especialmente que las estadísticas judiciales son importantes para aportar a la comprensión de la respuesta del sistema de justicia penal ante la violencia contra las mujeres, por ejemplo, al permitir evaluar la eficacia de las leyes y sanciones destinadas a proteger a las mujeres utilizando las estadísticas de reincidencia. Al respecto, la Convención para la eliminación de todas las formas de discriminación contra la mujer (CEDAW) establece obligaciones positivas de información en materia de educación (artículo 10), salud para las mujeres rurales (artículo 14.2.b) y planificación familiar (artículo 16.1.e). Asimismo, el Comité de la CEDAW ha señalado que "los Estados partes tienen la responsabilidad internacional de crear y mejorar constantemente sus bases de datos estadísticos y profundizar el análisis de todas las formas de discriminación contra las mujeres en general y, en particular, contra las mujeres de determinados grupos vulnerables". En tal sentido, el Comité ha recomendado a los Estados alentar "la recopilación de estadísticas y la investigación de la amplitud, las causas y los efectos de la violencia y de la eficacia de las medidas para prevenir y responder a ella" y más específicamente, analizar y usar datos sobre la violencia contra la mujer, particularmente en relación al número de casos reportados, procesamientos y condenas, así como también sobre las sentencias impuestas a los perpetradores y la compensación, a fin de determinar los beneficios de la ley, y elaborar políticas y programas para promover el acceso de las mujeres a la justicia (CIDH, Acceso a la justicia para mujeres víctimas de violencia en las Américas, 20 de enero de 2007, párr. 42; Ver, por ejemplo, Naciones Unidas, Resolución 26/15 del Consejo de 
Derechos Humanos: Acelerar los esfuerzos para eliminar todas las formas de violencia contra la mujer: la violencia contra la mujer como obstáculo para el empoderamiento político y económico de la mujer, 11 de julio de 2014, U.N. Doc. A/HRC/RES/26/15, párr. 7; Naciones Unidas, Resolución 23/7 del Consejo de Derechos Humanos: Eliminación de la discriminación contra la mujer, 20 de junio de 2013, U.N. Doc. A/HRC/RES/23/7, párr. 12; Naciones Unidas, Informe del Grupo de Trabajo sobre la cuestión de la discriminación contra la mujer en la legislación y en la práctica, 19 de abril de 2013, U.N. Doc. A/HRC/23/50, párr. 97(g); Naciones Unidas, Intensificación de los esfuerzos para eliminar todas las formas de violencia contra la mujer. Informe del Secretario General, 1 de agosto de 2012, U.N. Doc. A/67/220, párr. 77-78. Véase por ejemplo: Naciones Unidas, Informe del Secretario General, Estudio a fondo sobre todas las formas de violencia contra la mujer, 6 de julio de 2006, U.N. Doc. A/61/122/Add.1, párr. 209, Acceso a la información, violencia contra las mujeres y administración de justicia en las Américas, Organización de los Estados Americanos).

En similar sentido, en el Informe del Secretario General de Naciones Unidas sobre la intensificación de los esfuerzos para eliminar todas las formas de violencia contra la mujer se entregan recomendaciones específicas respecto de las obligaciones que deben cumplir los Estados en materia de recopilación, difusión y uso de la información sobre violencia contra las mujeres: "Los Estados deben asegurar la reunión y difusión sistemáticas y coordinadas de datos, así como su análisis, en particular en lo que respecta a la prevalencia, la frecuencia, las causas y las consecuencias de la violencia contra la mujer y el impacto de las medidas que se adopten para combatir esa violencia. Los datos estadísticos deben desglosarse por sexo, raza, edad, grupo étnico y otras características pertinentes. [...] Los Estados deben utilizar los datos disponibles para observar de cerca las tendencias y los avances que se logren, y basar en ellos las reformas de legislación y políticas y la prestación de servicios focalizados y eficaces. Es fundamental que se elaboren normas uniformes para la reunión de datos y se desarrolle la capacidad de los especialistas en estadística, a fin de que los datos se reúnan de modo que se tengan en cuenta consideraciones de género. Deben intensificarse las investigaciones cualitativas para que en ellas se aborden los factores económicos, políticos y sociales que son determinantes en la violencia contra la mujer" (Naciones Unidas, Intensificación de los esfuerzos para eliminar todas las formas de violencia contra la mujer. Informe del Secretario General, 1 de agosto de 2012, U.N. Doc. 
A/67/220, párr. 77-78. Capítulo 2 Estándares sobre el derecho al acceso a la información pública).

En consecuencia, en materia de acceso a la información para la prevención de la violencia y discriminación contra las mujeres, los Estados tienen una obligación específica de producir estadísticas adecuadas y otras clases de información pertinente sobre las causas, consecuencias y frecuencia de la violencia contra las mujeres. Dicha información debe utilizarse como base para el diseño y la evaluación de la eficacia de las políticas públicas y demás medidas adoptadas para prevenir, sancionar y erradicar la violencia y la discriminación contra las mujeres. La Comisión IDH ha reiterado frecuentemente que la labor de recopilación de datos - cuantitativos y cualitativos realizada por el Estado es fundamental para comprender plenamente la dimensión de los problemas existentes y diseñar adecuadamente leyes y políticas públicas con el fin de responder a esos problemas" (CIDH, Comunicado de prensa 9/13: La CIDH concluye su visita de trabajo a Suriname, 12 de febrero de 2013).

La CIDH subraya la importancia que los Estados incorporen a las mujeres y las organizaciones que las representan a sus mecanismos de recolección de información. En este sentido, la Comisión ha señalado anteriormente que "las actividades de recopilar información por parte de los Estados deben llevarse a cabo en colaboración y consulta con diversos sectores que cuentan con información clave, incluidas las víctimas, sus comunidades, centros y entidades estatales que se encargan del tema, el sector académico, organismos internacionales y organizaciones de la sociedad civil. Es imprescindible institucionalizar la colaboración entre los productores de estadísticas y los usuarios"(CIDH, Acceso a la justicia para mujeres víctimas de violencia en las Américas, 20 de enero de 2007, párr. 44).

\section{b) LA OBLIGACIÓN DE TRANSPARENCIA ACTIVA}

Según ha sostenido la CIDH, "la obligación de suministrar oficiosamente información (llamada también obligación de transparencia activa), apareja el deber de los Estados de suministrar información pública que resulte indispensable para que las personas puedan ejercer sus derechos fundamentales o satisfacer sus necesidades básicas en este ámbito" (CIDH, Acceso a la información en materia reproductiva desde una perspectiva de derechos humanos, 22 de noviembre de 2011, párr. 25). 
Respecto al alcance de la obligación de transparencia activa, la Comisión IDH ha señalado que los Estados tienen la obligación de suministrar al público "la máxima cantidad de información en forma oficiosa, por lo menos en cuanto a: (a) la estructura, funciones y presupuesto de operación e inversión del Estado; (b) la información que se requiere para el ejercicio de otros derechos - por ejemplo, la que atañe a la satisfacción de los derechos sociales como los derechos a la pensión, a la salud o a la educación-; (c) la oferta de servicios, beneficios, subsidios o contratos de cualquier tipo; y (d) el procedimiento para interponer quejas o consultas, si existiere" (CIDH, El derecho de acceso a la información en el marco jurídico Interamericano, Segunda Edición, Relatoría Especial para la Libertad de Expresión, 7 de marzo de 2011, párr. 32).

Entre la información necesaria para el ejercicio de otros derechos, la Ley Modelo Interamericana dispone que los Estados deben diseminar proactivamente la información sobre los mecanismos de presentación de solicitudes o denuncias; una descripción de las facultades y deberes de sus funcionarios principales y los procedimientos que se siguen para tomar decisiones; todas las leyes, reglamentos, resoluciones, políticas, lineamientos o manuales $\mathrm{u}$ otros documentos que contengan interpretaciones, prácticas o precedentes sobre el desempeño del órgano en el cumplimiento de sus funciones que afectan al público en general; así como todo mecanismo o procedimiento por medio del cual el público pueda presentar peticiones o de alguna otra manera incidir en la formulación de políticas públicas (OEA, Ley modelo interamericana sobre acceso a la información pública, AG/RES. 2607 (XLO/10), Aprobada en la cuarta sesión plenaria, celebrada el 8 de junio de 2010, párr. 11.1).

En materia de discriminación y violencia, la $\mathrm{CIDH}$ ha reconocido que las mujeres sólo pueden reclamar sus derechos cuando los conocen (CIDH, Acceso a la justicia para mujeres víctimas de violencia en las Américas, 20 de enero de 2007, párr. 231).

La Comisión reitera que, en efecto, "la falta de información sobre los recursos judiciales disponibles y el hecho de que la violencia y la discriminación todavía sean hechos aceptados en las sociedades americanas, dan como resultado un reducido número de denuncias de actos de violencia contra las mujeres"(CIDH, Acceso a la justicia para mujeres víctimas de violencia en las Américas, 20 de enero de 2007, párr. 231). Destacando la necesidad de transparencia activa, ISIS Internacional describió el problema como sigue: Se constata que existe desconocimiento de sus derechos por parte 
de las mujeres. En general las mujeres, en particular las de escasos recursos, desconocen sus derechos y los mecanismos existentes para hacerlos valer. La violencia en contra de las mujeres sigue siendo una práctica extendida, aceptada culturalmente, frente a lo cual las normas aparecen como una medida regulatoria, pero que no aseguran por sí solas el cambio cultural que es necesario para erradicarla (CIDH, Acceso a la justicia para mujeres víctimas de violencia en las Américas, 20 de enero de 2007, párr. 231; Elizabeth Guerrero, Violencia contra las Mujeres en América Latina y el Caribe: Balance de una Década 1990-2000, Isis Internacional, Santiago, Chile, Abril 2002, pág. 21. Capítulo 2 Estándares sobre el derecho al acceso a la información pública en materia de violencia y discriminación contra las mujeres, Comisión Interamericana de Derechos Humanos).

En consecuencia, en esta materia la transparencia activa implica la obligación estatal de difundir información sobre los derechos de las mujeres y las vías legales para exigirlos y hacerlos efectivos, así como información relacionada con el desarrollo de leyes y políticas públicas sobre violencia y discriminación, y que tengan voz en el diseño de las mismas. Dicha información debe ser completa, comprensible, con un lenguaje accesible y encontrarse actualizada.

Al respecto, el Comité CEDAW ha señalado que la política que sigan los Estados para eliminar la discriminación contra las mujeres “deberá asegurar que las mujeres, tanto de manera individual como grupal, tengan acceso a la información sobre sus derechos en virtud de la Convención y puedan promoverlos y reivindicarlos efectivamente. El Estado parte también debería asegurar que la mujer pueda participar en forma activa en la formulación, la aplicación y el seguimiento de la política. Para lograrlo deben asignarse recursos a fin de asegurarse de que las organizaciones no gubernamentales dedicadas a los derechos humanos y la condición de la mujer estén debidamente informadas, se las consulte como corresponde y en general puedan desempeñar una función activa en la formulación inicial y posterior desarrollo de esa política" (Naciones Unidas, Comité para la Eliminación de la Discriminación contra la Mujer, Recomendación General $N^{\circ}$ 28: las obligaciones fundamentales de los Estados partes bajo el artículo 2 de la Convención sobre la eliminación de todas las formas de discriminación contra la mujer, 16 de diciembre de 2010, U.N.Doc CEDAW/C/GC/28, párr. 27). 
Lo anterior implica la obligación estatal de crear espacios de participación para que las mujeres receptoras de la información producida por el Estado tengan la posibilidad de ser oídas respecto de sus necesidades específicas en materia de acceso a la información. Todo esto resulta particularmente relevante en el caso de las mujeres que forman parte de grupos tradicionalmente marginados, tales como las mujeres indígenas y afrodescendientes, pues ellas enfrentan mayores barreras para acceder a la información pública y a los espacios formales de participación.

Al respecto, la Comisión recuerda que, como ha sostenido en el pasado, para alcanzar los objetivos de difusión efectiva de la información en materia de discriminación y violencia resulta fundamental que los Estados adopten medidas concretas orientadas a "legitimar, proteger y apoyar el trabajo de las organizaciones no gubernamentales que prestan servicios interdisciplinarios a las víctimas de violencia, a través de recursos financieros y de políticas públicas, especialmente en cuanto a la provisión de información sobre la forma de interponer denuncias ante actos de violencia contra las mujeres y cómo acceder a una tutela judicial efectiva" (CIDH, Acceso a la justicia para mujeres víctimas de violencia en las Américas, 20 de enero de 2007, párr. 239).

Sobre este punto, la CIDH subraya que resulta fundamental que los Estados adopten medidas concretas destinadas a proteger a las organizaciones y periodistas que trabajan en la investigación, promoción y defensa de los derechos de las mujeres, especialmente cuando ejercen solicitudes al Estado para el acceso a la información pública. En este sentido, la Ley Modelo Interamericana sobre Acceso a la Información Pública dispone la obligación en cabeza del Estado de garantizar que "el solicitante no será sancionado, castigado o procesado por el ejercicio del derecho de acceso a la información".

En esta línea, la Asamblea General de la OEA en su resolución AG/RES 2579 (XL-0/10) ha reconocido el trabajo que las mujeres defensoras de derechos humanos realizan en la región y ha señalado que en virtud de la actuación y necesidades específicas de su sexo, y los riesgos particulares que enfrentan a raíz de la discriminación histórica que han sufrido, las mujeres defensoras de derechos humanos merecen que los Estados aseguren la plena protección y eficacia de las importantes actividades que realizan. Los deberes estatales de prevención y repuesta en esta materia no se limita a proporcionar medidas materiales a las defensoras en riesgo a fin de proteger su integridad personal, o al asegurar que sus agentes no interfieran en el pleno 
ejercicio de sus derechos humanos. Conlleva asimismo el deber de actuar sobre las causas estructurales que afectan su seguridad, con el fin de crear las condiciones necesarias para el efectivo goce y disfrute de los derechos establecidos en la Convención Americana.

c) LA OBLIGACIÓN DE RESPONDER DE MANERA OPORTUNA LAS SOLICITUDES DE ACCESO A LA INFORMACIÓN Y GARANTIZAR UN RECURSO EFECTIVO QUE PERMITA LA SATISFACCIÓN DEL DERECHO.

Si bien en este campo la transparencia activa es el principal medio para garantizar el acceso a la información de las mujeres, la Comisión recuerda que los Estados también tienen la obligación de garantizar efectivamente el acceso a la información pública para quienes formulen solicitudes en tal sentido.

En relación con el recurso que debe encontrarse disponible para que las personas puedan efectuar solicitudes de información al Estado, la Comisión ha señalado que éste debe reunir las siguientes características: (a) debe ser un recurso sencillo, de fácil acceso para todas las personas, que sólo exija el cumplimiento de requisitos básicos tales como: la identificación razonable de la información solicitada y los datos requeridos para que la administración pueda entregarle la información al interesado; (b) debe ser gratuito o de bajo costo, de tal forma que no desaliente las solicitudes de información; (c) debe establecer plazos cortos pero razonables para que las autoridades suministren la información requerida; (d) debe permitir que las solicitudes se hagan de forma oral en los casos en que no pueda realizarse por escrito, por ejemplo, por no conocer la lengua, por no saber escribir o en situaciones de extrema urgencia; (e) debe establecer la obligación de la administración de asesorar al solicitante sobre la manera de formular la solicitud, incluyendo la asesoría sobre la autoridad facultada por la ley para responder, incluso hasta el punto de que la propia autoridad haga la correspondiente remisión informando del trámite a la persona interesada; y (f) debe establecer la obligación de que la respuesta negativa sea motivada y la posibilidad de que ésta pueda ser impugnada ante un órgano superior o autónomo y posteriormente cuestionada en la vía judicial.

Al respecto, la CIDH reitera que los Estados no pueden exigir a quienes solicitan información justificar las razones de la solicitud y que incluso el derecho a realizar solicitudes puede ejercerse en forma anónima. 
Finalmente, la CIDH advierte que la respuesta a solicitudes de información para prevenir y erradicar la violencia y discriminación contra las mujeres muchas veces revelan vacíos en la disponibilidad de información. En este tipo de asuntos y de acuerdo con el principio de progresividad, los Estados deben asegurar de manera proactiva que la información de interés público que se obtiene mediante solicitudes de información, sea posteriormente divulgada y esté disponible a toda la sociedad, de manera que no sea necesario el uso de recursos para obtenerla.

\subsection{ORGANISMOS INTERNACIONALES DE DERECHOS HUMANOS DE} AMÉRICA (OEA, ONU)

Debemos aquí reconocer cuáles son las instituciones encargadas de la producción del derecho internacional de los Derechos Humanos, a los fines de su comprensión y evaluación de su importancia como autoridad internacional, que como jurisdicción supraestatal pesa sobre Argentina en esta materia. En este apartado solamente mencionaremos aquéllos que hacen a nuestra relación inmediata con el continente americano tanto regionales como universales, por haber firmado tratados con dicha región. Quedando para otro estudio futuro aquellos organismos de Europa (actualmente Corte Europea de Derechos Humanos) y de África (Corte Africana de Derechos Humanos y de los Pueblos).

\section{I) NACIONES UNIDAS}

a) Órganos basados en la Carta de Naciones Unidas: Consejo de Derechos Humanos; Exámen Periódico Universal; Los Procedimientos Especiales.

El Consejo, cuya primera reunión se celebró el 19 de junio de 2006, es un órgano intergubernamental, que se reúne en Ginebra durante 10 semanas al año, está compuesto por 47 Estados miembros de las Naciones Unidas elegidos por un periodo inicial de tres años, y no pueden ser elegidos por más de dos periodos consecutivos. El Consejo de Derechos Humanos es un foro que tiene la facultad de prevenir los abusos, la desigualdad y la discriminación, proteger a los más vulnerables y denunciar a los perpetradores.

Los Procedimientos Especiales se refieren de manera general a los mecanismos establecidos por la Comisión de Derechos Humanos y asumidos por el Consejo de 
Derechos Humanos para abordar bien sea situaciones específicas en los países o cuestiones temáticas en todo el mundo.

El Examen Periódico Universal (EPU) es un proceso único que implica una revisión de los registros de todos los Estados Miembros de la ONU sobre derechos humanos. El EPU es un proceso impulsado por los Estados, bajo los auspicios del Consejo de Derechos Humanos, que ofrece la oportunidad a todos los Estados a declarar qué acciones se han tomado para mejorar la situación de derechos humanos en sus países y para cumplir con sus obligaciones de derechos humanos.

b) Órganos de Tratados: en lo que hace a nuestro tema, encontramos el Comité de Derechos Humanos y el Comité para la Eliminación de la Discriminación contra la Mujer (CEDAW). Hay nueve principales tratados internacionales de derechos humanos, uno de los cuales, sobre desapariciones forzadas, no ha entrado aún en vigor.

El Comité de Derechos Humanos es el órgano de expertos independientes que supervisa la aplicación del Pacto Internacional de Derechos Civiles y Políticos por sus Estados Partes. Todos los Estados Partes están obligados a presentar informes periódicos al Comité sobre cómo se aplican los derechos. Los Estados deben presentar el primer informe un año después de adherirse al Pacto y luego siempre que el Comité lo pide (por lo general cada cuatro años). El Comité examina cada informe y expresa sus preocupaciones y recomendaciones al Estado Parte en forma de "observaciones finales".

El Comité para la Eliminación de la Discriminación contra la Mujer (CEDAW) es el órgano de expertos independientes que supervisa la aplicación de la Convención sobre la Eliminación de todas las Formas de Discriminación contra la Mujer. Consta de 23 expertos sobre los derechos de las mujeres de todo el mundo. Los países que se han convertido en parte en el tratado (Estados partes) como Argentina, están obligados a presentar informes periódicos al Comité sobre cómo se aplican los derechos de la Convención. De conformidad con el Protocolo Facultativo de la Convención, el Comité tiene el mandato de: (1) recibir comunicaciones de personas o grupos de personas que presentan denuncias de violaciones de los derechos protegidos por la Convención al Comité, y (2) iniciar investigaciones en situaciones graves o violaciones sistemáticas de 
los derechos de la mujer. Estos procedimientos son opcionales y sólo están disponibles cuando el Estado interesado las ha aceptado. El Comité también formula recomendaciones generales y sugerencias. Las recomendaciones generales se dirigen a los Estados.

Aunque la sede principal está en Nueva York (Estados Unidos de América) la ONU y sus organismos especializados y regionales tienen otras sedes, como en Ginebra (Suiza); La Haya (Paises Bajos); Viena (Austria); Montreal (Canadá); Copenhague (Dinamarca); Bonn (Alemania); Nairobi (Kenia); París (Francia); Santiago de Chile (Chile); Adís Abeba (Etiopía); Valencia (España) y Buenos Aires (Argentina) .

\section{II) ORGANIZACIÓN DE ESTADOS AMERICANOS}

La Organización de los Estados Americanos es el organismo regional más antiguo del mundo, cuyo origen se remonta a la Primera Conferencia Internacional Americana, celebrada en Washington, D.C., de octubre de 1889 a abril de 1890. En esta reunión, se acordó crear la Unión Internacional de Repúblicas Americanas y se empezó a tejer una red de disposiciones e instituciones que llegaría a conocerse como "sistema interamericano", el más antiguo sistema institucional internacional. La OEA fue creada en 1948 cuando se subscribió, en Bogotá, Colombia, la Carta de la OEA que entró en vigencia en diciembre de 1951. Posteriormente, la Carta fue enmendada por el Protocolo de Buenos Aires, suscripto en 1967, que entró en vigencia en febrero de 1970; por el Protocolo de Cartagena de Indias, suscripto en 1985, que entró en vigencia en noviembre de 1988; por el Protocolo de Managua, suscripto en 1993, que entró en vigencia en enero de 1996, y por el Protocolo de Washington, suscripto en 1992, que entró en vigor en septiembre de 1997.

La Organización fue fundada con el objetivo de lograr en sus Estados Miembros, como lo estipula el Artículo 1 de la Carta, "un orden de paz y de justicia, fomentar su solidaridad, robustecer su colaboración y defender su soberanía, su integridad territorial y su independencia". Hoy en día, la OEA reúne a los 35 Estados independientes de las Américas y constituye el principal foro gubernamental político, jurídico y social del Hemisferio. Además, ha otorgado el estatus de Observador Permanente a 67 Estados, así como a la Unión Europea (UE). Para lograr sus más importantes propósitos, la OEA se basa en sus principales pilares que son la democracia, los derechos humanos, la seguridad y el desarrollo. 
Los Estados americanos reafirman los siguientes principios y de conformidad con la teoría Idealista:

a. El derecho internacional es norma de conducta de los Estados en sus relaciones recíprocas.

b. El orden internacional está esencialmente constituido por el respeto a la personalidad, soberanía e independencia de los Estados y por el fiel cumplimiento de las obligaciones emanadas de los tratados y de otras fuentes del derecho internacional.

c. La buena fe debe regir las relaciones de los Estados entre sí.

d. La solidaridad de los Estados americanos y los altos fines que con ella se persiguen, requieren la organización política de los mismos sobre la base del ejercicio efectivo de la democracia representativa.

e. Todo Estado tiene derecho a elegir, sin injerencias externas, su sistema político, económico y social, y a organizarse en la forma que más le convenga, y tiene el deber de no intervenir en los asuntos de otro Estado. Con sujeción a lo arriba dispuesto, los Estados americanos cooperarán ampliamente entre sí y con independencia de la naturaleza de sus sistemas políticos, económicos y sociales. f. La eliminación de la pobreza crítica es parte esencial de la promoción y consolidación de la democracia representativa y constituye responsabilidad común y compartida de los Estados americanos.

g. Los Estados americanos condenan la guerra de agresión: la victoria no da derechos.

h. La agresión a un Estado americano constituye una agresión a todos los demás Estados americanos.

i. Las controversias de carácter internacional que surjan entre dos o más Estados americanos deben ser resueltas por medio de procedimientos pacíficos.

j. La justicia y la seguridad sociales son bases de una paz duradera.

k. La cooperación económica es esencial para el bienestar y la prosperidad comunes de los pueblos del Continente.

1. Los Estados americanos proclaman los derechos fundamentales de la persona humana sin hacer distinción de raza, nacionalidad, credo o sexo. 
m. La unidad espiritual del Continente se basa en el respeto de la personalidad cultural de los países americanos y demanda su estrecha cooperación en las altas finalidades de la cultura humana.

n. La educación de los pueblos debe orientarse hacia la justicia, la libertad y la paz.

\section{A) CORTE INTERAMERICANA DE DH}

La Corte Interamericana de Derechos Humanos, con sede en San José Costa Rica, es una institución judicial autónoma de la Organización de los Estados Americanos cuyo objetivo es la aplicación e interpretación de la Convención Americana sobre Derechos Humanos y de otros tratados concernientes al mismo asunto y fue establecida en 1979. Está formada por juristas de la más alta autoridad moral y reconocida competencia en materia de derechos humanos elegidos a título personal. En noviembre de 1969 se celebró en San José de Costa Rica la Conferencia Especializada Interamericana sobre Derechos Humanos. En ella, los delegados de los Estados Miembros de la Organización de los Estados Americanos redactaron la Convención Americana sobre Derechos Humanos, que entró en vigor el 18 de julio de 1978, al haber sido depositado el undécimo instrumento de ratificación por un Estado Miembro de la OEA. A la fecha, veinticinco naciones Americanas han ratificado o se han adherido a la Convención: Argentina, Barbados, Bolivia, Brasil, Colombia, Costa Rica, Chile, Dominica, Ecuador, El Salvador, Granada, Guatemala, Haití, Honduras, Jamaica, México, Nicaragua, Panamá, Paraguay, Perú, República Dominicana, Surinam, Trinidad y Tobago, Uruguay y Venezuela.

\section{B) COMISIÓN INTERAMERICANA DE DH:}

La Comisión Interamericana de Derechos Humanos (CIDH) es una de las dos entidades del sistema interamericano de protección y promoción de los derechos humanos en las Américas. Tiene su sede en Washington, D.C. La CIDH es un órgano principal y autónomo de la Organización de los Estados Americanos (OEA), cuyo mandato surge de la Carta de la OEA y de la Convención Americana sobre Derechos Humanos, y que actúa en representación de todos los países miembros de la OEA. Está integrada por siete miembros independientes que se desempeñan en forma personal, que no representan a ningún país en particular y que son elegidos por la Asamblea General. La CIDH se reúne en períodos ordinarios y extraordinarios de sesiones varias veces por 
año. Su Secretaría Ejecutiva cumple las instrucciones de la CIDH y sirve de apoyo para la preparación legal y administrativa de sus tareas. La Comisión tiene la función principal de promover la observancia y la defensa de los derechos humanos (Sitio web www.cidh.oas.org).

\subsection{NORMAS INTERNACIONALES DE DERECHOS HUMANOS} OBLIGATORIAS EN VIOLENCIA CONTRA LA MUJER Y EN ESPECIAL EL ACOSO SEXUAL LABORAL

En este apartado mencionaremos -ya que su desarrollo fue elaborado al hablar específicamente de ellos- los textos internacionales cuyo valor jurídico normativo no está dubitado, y que hacen a la protección internacional de la mujer contra la violencia incluído el acoso sexual laboral y de qué modo influyen en la normativa de Argentina por ser parte firmante de dichos textos, y/o países latinos o anglosajones. Así estaremos desarrollando los objetivos específicos en cuanto a la evolución de las normas en sí y sobre su aplicación y protección efectiva (objetivo general).

Aunque la Declaración Universal de Derechos Humanos (ONU, Asamblea General, París, 1948), prohibió todo tipo de discriminación, incluso por razón del sexo (artículo 2) y los dos pactos internacionales aprobados el 16 de diciembre de 1966 (ONU) prohibieron igualmente la discriminación de este tipo en términos generales (El Pacto Internacional de Derechos Económicos, Sociales y Culturales, Asamblea general de la UN del 16-12-1966, párrafo 2 del artículo 2, y artículo 3. Ley 23.313 y El Pacto Internacional de Derechos Civiles y Políticos y su Protocolo Facultativo, Asamblea general de la UN del 16-12-1966, párrafo 1 del artículo 2, artículo 3 y artículo 26, Ley 23.313), sólo el 18 de diciembre de 1979, cuando la Asamblea General de las Naciones Unidas aprobó la Convención sobre la Eliminación de todas las Formas de Discriminación contra la Mujer, se logró la aceptación internacional de la definición amplia de discriminación dirigida concretamente contra la mujer. En el párrafo 1 del artículo 11 de la Convención se establece que los Estados que la hayan ratificado «adoptarán todas las medidas apropiadas para eliminar la discriminación contra la mujer en la esfera del empleo». Sobre esta base general, el Comité para la Eliminación de la Discriminación contra la Mujer, establecido en virtud de la Convención, aprobó en enero de 1992 la Recomendación General núm. 19 sobre la violencia contra la mujer 
(Naciones Unidas: Informe del Comité para la Eliminación de la Discriminación contra la Mujer, $11^{\circ}$ período de sesiones, Asamblea General, Documentos Oficiales, cuadragésimo séptimo período de sesiones, Suplemento núm. 38, A/47/38 (Nueva York, 1992), págs. 1-6).

Aunque las recomendaciones generales de este tipo no son vinculantes para los Estados que han ratificado la Convención, la declaración de acoso sexual efectuada por el indicado Comité es digna de mención con el fin de poner de manifiesto su utilidad para los tribunales nacionales que tengan que conocer denuncias en casos en que las leyes nacionales quizás no sean claras. Dicha recomendación dice lo siguiente: “ 17. La igualdad en el empleo puede verse seriamente perjudicada cuando se somete a las mujeres a violencia dirigida concretamente a ellas, por su condición de tales, por ejemplo, el hostigamiento sexual en el lugar de trabajo.18. El hostigamiento sexual incluye conductas de tono sexual tal como contactos físicos e insinuaciones, observaciones de tipo sexual, exhibición de pornografía, y exigencias sexuales ya sean verbales o de hecho. Ese tipo de conducta puede ser humillante y puede constituir un problema de salud y de seguridad; es discriminatoria cuando la mujer tiene motivos suficientes para creer que su negativa le podría causar problemas en relación con su trabajo, incluso con la contratación o el ascenso, o cuando crea un medio de trabajo hostil... 24. A la luz de las observaciones anteriores, el Comité para la Eliminación de la Discriminación contra la Mujer recomienda que: ...j) los Estados incluyan en sus informes datos sobre el hostigamiento sexual y sobre las medidas adoptadas para proteger a la mujer del hostigamiento sexual y de otras formas de violencia o coacción en el lugar de trabajo; ... t) los Estados adopten todas las medidas jurídicas y de otra índole que sean necesarias para prestar protección eficaz a las mujeres contra la violencia dirigida a ellas, incluidas entre otras: i) medidas jurídicas eficaces, incluidas sanciones penales, recursos civiles y disposiciones de indemnización para proteger a la mujer contra todo tipo de violencia, incluida la violencia y los malos tratos en la familia, el ataque sexual y el hostigamiento sexual en el lugar de trabajo; ii) medidas preventivas, incluidos programas de información pública y de educación para modificar las actitudes relativas a las funciones y la condición del hombre y de la mujer". No se puede ser más claro sobre esta cuestión. Ahora bien, una lectura atenta de los informes presentados por los Estados al Comité durante los últimos cinco años en virtud de lo dispuesto en la Convención pone de manifiesto que muy pocos gobiernos incluyen en la práctica información sobre el acoso sexual, tanto en general como en el trabajo. 
Asimismo, los expertos presentes en el Comité formulan pocas observaciones con respecto al acoso sexual en general o en los centros de trabajo. Además del interés demostrado en el problema del acoso sexual por los órganos de las Naciones Unidas creados en virtud de tratados, sus comisiones orgánicas, sobre todo la Comisión de Derechos Humanos, también se han ocupado de esta cuestión, si bien indirectamente. En su $50^{\circ}$ período de sesiones, la indicada Comisión aprobó una resolución (Resolución 1994/45 de 4 de marzo de 1994, titulada «Cuestión de la integración de los derechos de la mujer en los mecanismos de derechos humanos de las Naciones Unidas y de la eliminación de la violencia contra la mujer») en la que decidió nombrar, por un período de tres años, un relator especial sobre la violencia contra la mujer, con inclusión de sus causas y consecuencias. En su informe preliminar a la Comisión de Derechos Humanos, la relatora especial sobre la violencia contra la mujer destacó el problema del acoso sexual contra las mujeres, dedicándole una sección independiente.

La OIT se distingue por ser el único organismo internacional que ha adoptado un instrumento que contiene disposiciones protectoras contra el acoso sexual. En el Convenio sobre pueblos indígenas y tribales, 1989 (núm. 169), se establece que los gobiernos deberán hacer cuanto esté en su poder por evitar cualquier discriminación entre los trabajadores pertenecientes a los pueblos originarios y los demás trabajadores. Las medidas adoptadas deberán en particular garantizar que los trabajadores pertenecientes a estos pueblos gocen de igualdad de oportunidades y de trato para hombres y mujeres en el empleo y de protección contra el hostigamiento sexual (apartado $d$ ) del párrafo 3 del artículo 20).

Como observamos, con el transcurso del tiempo, se ha ido forjando un consenso por parte de la comunidad internacional que reconoce la violencia contra la mujer como un problema de derechos humanos que requiere una proactiva y urgente intervención de los Estados. Este consenso encuentra reflejo en los numerosos instrumentos internacionales (ejemplo: Convención Interamericana para Prevenir, Sancionar y Erradicar la Violencia contra la Mujer en adelante, "Convención de Belém do Pará", artículo 7(b)), declaraciones (ejemplo: Declaración de Naciones Unidas sobre la Eliminación de la Violencia contra la Mujer) y plataformas que cuentan con amplio respaldo estatal (ejemplo: Declaración y Plataforma de Acción de Beijing, Cuarta Conferencia Mundial sobre la Mujer, 15 de septiembre de 1995), resoluciones de la 
Asamblea General aprobadas por consenso (ejemplo: Resolución de la Asamblea General de las Naciones Unidas, Consejo de Derechos Humanos, Acelerar los esfuerzos para eliminar todas las formas de violencia contra la mujer: garantizar la diligencia debida en la prevención, A/HRC/14/L.9/Rev.1, 16 de junio de 2010; Resolución de la Asamblea General de las Naciones Unidas, Intensificación de los esfuerzos para eliminar todas las formas de violencia contra la mujer, A/RES/64/137, 11 de febrero de 2010 (aprobada sin votación); Naciones Unidas, Declaración sobre la eliminación de la violencia contra la mujer, Resolución de la Asamblea General 48/104, 20 de diciembre de 1993, A/RES/48/104, 23 de febrero de 1994 (aprobada sin votación), opiniones de los órganos de tratados (por ejemplo, Naciones Unidas, Comité para la Eliminación de la Discriminación contra la Mujer, Recomendación General 19, La violencia contra la mujer, ONU Doc. HRI/GEN/1//Rev.1 (1994), párr. 11), jurisprudencia de los sistemas regional (por ejemplo, Sistema Interamericano de Derechos Humanos, CIDH, Informe No 28/07, Casos 12.496-12.498, Claudia Ivette González y Otros, Informe sobre el Fondo (México), 9 de marzo de 2007; Corte Interamericana de Derechos Humanos, Caso de González et al. ("Campo Algodonero”) c. México, Sentencia de 16 de noviembre de 2009; CIDH “Acceso a la Justicia para Mujeres Víctimas de Violencia en las Américas", 20 de enero de 2007, Corte Europea de Derechos Humanos, Caso de Opuz c. Turquía, Aplicación No. 33401/02, 9 de junio de 2009, párr. 246; Comité para la Eliminación de la Discriminación contra la Mujer, Opinión sobre la Comunicación No. 6/2005, Fatma Yildrim c. Austria, 21 de julio de 2004, párr. 12.1.1; Comité para la Eliminación de la Discriminación contra la Mujer, Opinión sobre la Comunicación No. 2/2003, A.T. c. Hungría, 26 de enero de 2003, párr. 9.2.), y universal de protección de derechos humanos (por ejemplo, Comité CEDAW, Observación General $\mathrm{N}^{\mathrm{o}} 19$, adoptada por el Comité para la Eliminación de la Discriminación contra la Mujer, $11^{\circ}$ período de sesiones, 1992, U.N. Doc. HRI $\backslash G E N \backslash 1 \backslash R$ ev.1 at 84 (1994) y pronunciamientos y recomendaciones de otros órganos internacionales expertos en la materia, y del derecho consuetudinario, así como otras fuentes del derecho internacional (ejemplo: ONU, Informe de la Relatoría Especial sobre la violencia contra la mujer).

La Relatoría Especial de las Naciones Unidas sobre la Violencia contra la Mujer establece que la obligación de la debida diligencia alcanzó la condición de norma del derecho internacional consuetudinario y obliga a los Estados a prevenir los actos de violencia contra la mujer y a actuar con la debida diligencia frente a tales actos (ONU, Informe de la Relatoría Especial sobre la violencia contra la mujer, con inclusión de sus 
causas y consecuencias. La norma de la debida diligencia como instrumento para la eliminación de la violencia contra la mujer, Comisión de Derechos Humanos, $62^{\circ}$ periodo de sesiones, E/CN.4/2006/61, 20 de enero de 2006, párr. 29).

Como vemos, la evolución de la creación y aplicación de las normas internacionales de Derechos Humanos data de mediados del siglo XX hasta la fecha, y se manifiesta en diversas regiones del planeta, habiendo dado un giro acelerado en las últimas décadas, ante la lucha de víctimas, sindicatos, organizaciones de derechos humanos, que exigen reconocimiento inmediato de tales derechos sobre todo en el ámbito laboral. Someramente expusimos el estado actual de desarrollo del derecho internacional de los derechos humanos en materia de violencia de género en especial el acoso sexual laboral. En particular, acerca del principio de debida diligencia para prevenir, investigar, sancionar y reparar los casos de violaciones a los derechos humanos en general que surge del derecho internacional de los derechos humanos, para luego referirnos específicamente al valor reforzado de este principio en su aplicación en casos de violencia de género es decir, hacia la mujer.

\subsection{ALGUNAS ESTADÍSTICAS QUE AVALAN EL DEBER DE DILIGENCIA} (DE LA OAVL) -Violencia Laboral y Sector de Actividad.

Al considerar las consultas recibidas por la Oficina de Asesoramiento de Violencia Laboral (OAVL) del Ministerio de Trabajo de la Nación de Argentina entre el año 2006 y el 2008 (450 casos) encontramos que la gran mayoría de la gente que se ha acercado en búsqueda de asesoramiento, se desempeña en el sector terciario. En efecto, tal como se desprende del siguiente gráfico, aproximadamente 4 de cada 5 consultas las efectuaron trabajadores de este sector de actividad. En segundo término, se ubican las realizadas por trabajadores que se desempeñan en el sector secundario (15\%). También se registraron casos en el sector primario pero de escasa significación numérica. 


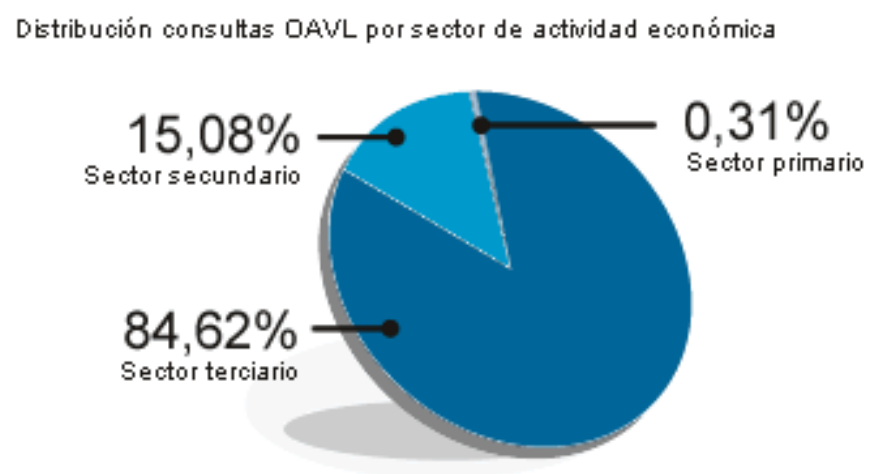

Esta distribución refleja en gran medida la estructura que, en el mismo sentido, se presenta en el mercado de trabajo del área Metropolitana (Ciudad de Buenos Aires y conurbano bonaerense), en la que la mayor cantidad de puestos de trabajo se concentran en los sectores de servicios e industria. Precisamente, en esta región trabaja la mayoría de los consultantes a quienes asesoró, hasta la fecha, la OAVL: el 74\% del total de trabajadores asesorados tiene su empleo en Capital Federal y el 18\% en provincia de Buenos Aires (principalmente conurbano). Cabe aclarar que los trabajadores del sector primario se localizan fuera de los centros urbanos. Al incorporar en el análisis la variable 'sexo' encontramos que:

- los consultantes que se desempeñan en el sector primario fueron, en todos los casos, varones;

- la proporción de mujeres y varones fue pareja en el grupo de consultantes que tienen sus empleos en el sector secundario;

- finalmente, en el sector terciario la mayoría de las consultantes fueron mujeres.

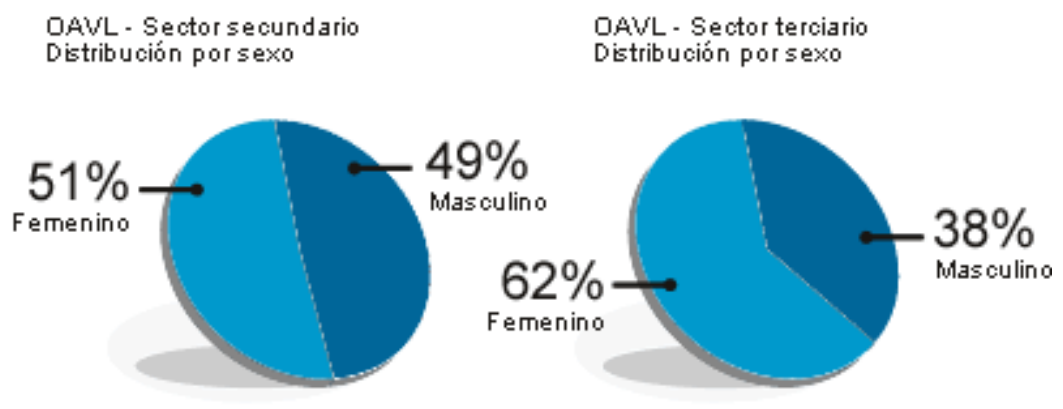

A la luz de estos datos cabría preguntarse por los factores que inciden en estos resultados y que podrían estar asociados a cuestiones institucionales y culturales así 
como a cuestiones de índole psico-sociológica. Entendemos además que este tipo de precisiones puede aportar a perfilar hipótesis de 1 trabajo que orienten las acciones de prevención necesarias.

Esta aproximación nos está mostrando que, si bien en el conjunto total de casos analizados, el $60 \%$ de las consultas las realizaron mujeres, es en el sector secundario en el que la incidencia del género resulta más notoria o significativa. Cabe considerar que en el mercado de trabajo la tasa de empleo femenino en industrias manufactureras es del 18,4 (año 2006). Una posible explicación se encuentra en el hecho de que el $43 \%$ de las consultas de este sector trabaja en fabricación de productos textiles, rama de actividad tradicionalmente femenina.

En el sector servicios las ramas más representadas son las de: servicios a empresas (27\%), salud (19\%), comercio (13\%) y hoteles y restaurantes $(10 \%)$. Para un mayor detalle en el siguiente gráfico se encuentran considerados los tres sectores y ramas de actividad por sexo. Algunas categorías se subdividieron para facilitar su comprensión.

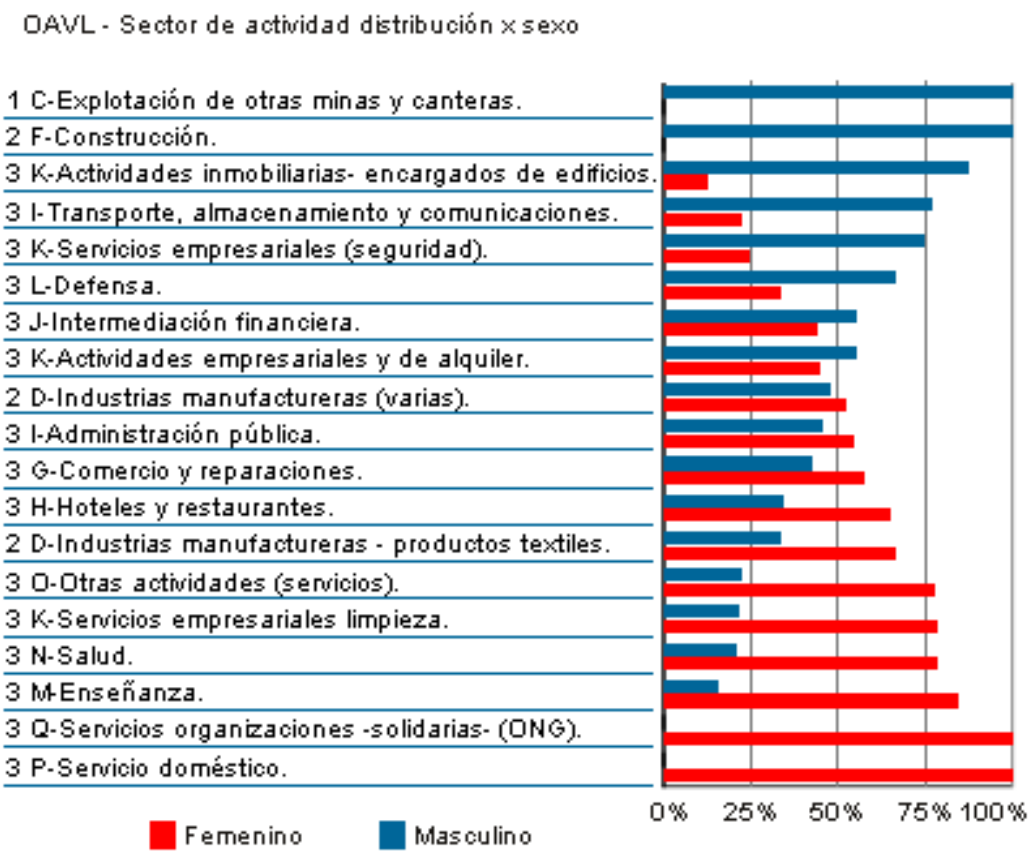

FUENTE DAVL: Sobre la derecha del gráfico la numeración corresponde al sector de actividad eononómica primario (1), secundario (2) o terciario (3).

3.21.1 Tipo de violencia por rama de actividad 
Al considerar el tipo de violencia que se registra en cada rama también surgen datos interesantes, teniendo en cuenta que en el conjunto de los casos predomina por amplia mayoría la violencia psicológica, tanto para varones como para mujeres.

Entre los casos atendidos por la OAVL en el sector de la construcción, actividad con mayoría de trabajadores varones, predomina la violencia física (71\%). Otras manifestaciones de violencia física se presentan en: comercio 27\%; industrias manufactureras $17 \%$; salud $11 \%$, intermediación financiera $11 \%$; otras actividades $11 \%$; servicios prestados a las empresas $9 \%$; hoteles y restaurantes $8 \%$; administración pública y defensa $6 \%$; enseñanza $5 \%$, transporte, almacenamiento y comunicaciones $5 \%$.

Por otra parte, hay sectores que presentan más casos de violencia sexual que otros, como por ejemplo: comercio $21 \%$, hoteles y restaurantes $15 \%$, servicios prestados a las empresas $10 \%$, industrias manufactureras $9 \%$, otras actividades $8 \%$ y enseñanza $5 \%$.

Ninguna persona resulta indemne ante situaciones de violencia laboral. El acoso, el maltrato, el ninguneo, las agresiones constantes, acciones destinadas a someterlo y/o excluirlo de su puesto de trabajo, entre otras formas de violencia laboral, suelen afectar la salud física y psicológica y producir consecuencias negativas en las relaciones sociales en general y familiares en particular. Al respecto, el $94 \%$ de los trabajadores asistidos hasta la fecha por la OAVL dio cuenta de afecciones derivadas de este tipo de situaciones. De hecho, al concurrir a la entrevista inicial, el 75\% de los consultantes se encontraba bajo tratamiento médico, psicológico y/o psiquiátrico o bien ya había realizado al menos una consulta.

Aproximadamente 8 de cada 10 consultantes hicieron referencia al impacto de las situaciones de violencia laboral en su salud mental: angustia, depresión, baja autoestima, ataques de pánico, pesadillas, olvidos y desorientación, son algunos de los efectos más frecuentemente mencionados. Por otra parte, 4 de cada 10 presentan afecciones en su salud física que comprenden: contracturas musculares, gastritis, mareos, entre otras. En el $77 \%$ de los casos de este conjunto, los síntomas físicos se presentan en forma simultánea con los psicológicos.

De manera esquemática, los daños provocados por situaciones de violencia laboral en la salud psicofísica y en la vida social de las personas pueden analizarse desde diferentes puntos de vista: 
Ámbito de trabajo: las personas afectadas comienzan a tener un rendimiento menor al habitual y/o a ausentarse por razones de salud. Esto, a su vez, puede convertirse en una justificación para profundizar el sometimiento o la exclusión. Ámbito personal: las actividades cotidianas y proyectos individuales, así como las relaciones familiares y sociales pueden verse restringidas y seguramente alteradas, debido a la pérdida de confianza, sentimientos de desesperanza y de injusticia. En el plano jurídico es interesante notar que, tanto en nuestro país como a nivel internacional, varios fallos que penalizan la violencia laboral reconocieron como parte de las pruebas ofrecidas las afecciones físicas y psicológicas sufridas por el denunciante. Para finalizar interesa considerar que, así como en otros ámbitos y tipos de violencia (maltrato infantil, violencia de género, etc.), el desconocimiento puede demorar la identificación del problema.

En ese sentido, a veces, la aparición de determinados síntomas físicos o psicológicos en ciertos contextos deben ser atendidos como signos a ser considerados. Dada la magnitud, gravedad y complejidad del tema es importante que médicos, psicólogos y psiquiatras conozcan y profundicen su conocimiento en el tema de modo tal de aportar a una recuperación más efectiva de la salud de los trabajadores afectados.

Las denuncias presentadas por ante la oficina respecto de agresión sexual en el ámbito laboral se sintetiza esquemáticamente en dos grandes grupos: EI acoso sexual: caracterizado por un repertorio de conductas de distinta índole entre las que se subrayan desde chistes obscenos y miradas lascivas hasta invitaciones sexuales directas o amenazas veladas o manifiestas, vividas todas ellas con desagrado y humillación por el denunciante. Este acoso puede ser ejercido por pares o subordinados y la sexualidad se constituye en un fin en si mismo y un medio que si bien tiene siempre impacto en la victima posee dispar suerte a nivel laboral. Cuando el acoso es llevado a cabo por un superior jerárquico se instrumenta en todos los casos como "chantaje sexual" implementado bajo la promesa de "prebendas" tales como ascensos, categorías más importantes o salarios más elevados, chantaje que al no ser aceptado genera una escalada de mayor agresión y la incorporación de otras modalidades de violencia que acorralan a la víctima a través del mensaje explícito o implícito de "la aceptación de la propuesta o las penurias laborales cuando no el desempleo". EI abuso sexual: Implica el pasaje a la acción física como atropello y que en su punto extremo configura la 
violación sexual. Si bien todo tipo de violencia laboral repercute física, psíquica y socialmente en la víctima produciendo similares efectos nocivos, la irrupción de la sexualidad en dicho ámbito genera los mayores estragos si se tiene en cuenta la absoluta falta de pertinencia y la total imprevisibilidad de la temática en situaciones en las que es dable esperar que las relaciones humanas circulen por senderos en donde si bien podrían preverse distintos tipos de conflictos y agresiones, la modalidad sexual es imposible de comprender y de controlar por lo que la integridad yoica de quien la padece queda totalmente desarticulada para poder elaborar una respuesta (OAVL, Ministerio de Trabajo de la Nación, 2006-2008). 


\section{Capítulo IV \\ PRODUCCIÓN LEGISLATIVA E INFORMES A Y DE LOS ORGANISMOS \\ INTERNACIONALES}

\subsection{ONU Y OEA. FUNDAMENTO JURÍDICO BASE DEL CUMPLIMIENTO DEL DERECHO INTERNACIONAL DE LOS DERECHOS HUMANOS}

En este capítulo junto con el que sigue, nos concentraremos en los indicadores de nuestra variable independiente, pasando revista asimismo al primer objetivo específico para así ver qué intereses (entendido como qué motivos, o voluntad) llevaron al éxito o fracaso de la aplicación de las normas internacionales y verificar que se haya alcanzado finalmente el objetivo general.

"Desde el punto de vista del Realismo, existe en el sistema internacional una "serie de normas -definidas por los países con posiciones de poder- que regulan el comportamiento de los actores internacionales y las relaciones entre éstos. Esa nota de jerarquización que tiene el orden internacional es lo que hace que el sistema internacional esté integrado y que los actores del sistema tengan distintos márgenes de acción, en función de sus posiciones relativas para con tales normas. En el pensamiento puigiano la existencia de jerarquías es explicada a partir de los criterios supremos de reparto que rigen las conductas de los actores internacionales. Esos criterios nos permiten clasificar a los actores en: repartidores supremos, intermedios $y$ recipendiarios (Puig, 1986:54). En ese mismo sentido, Dallanegra Pedraza (2003:1) expresa: [la comunidad internacio nal] está estructurada alrededor de una serie de reglas claramente definidas, no establecidas, desde ya, por los países carentes de poder de decisión. A título ejemplificativo, los Acuerdos de Bretton Woods -y su resultante, el FMI y el BM-, el GATT, hoy la OMC, el Club de París, las UNCTAD, son los instrumentos que han estructurado o estructuran la forma en que se dan las relaciones entre sus miembros, y también se encargan de sancionar a quienes no cumplen sus decisiones" (Falomir, 2009).

Sobre el punto de vista del Idealismo, ya fue explicado en la introducción, y a lo largo de las normas internacionales citadas en el primer y segundo capítulos. Y en el capítulo anterior reforzamos al tratar los organismos internacionales de derechos 
humanos. Repasemos pues solamente los conceptos principales para lograr obtener el valor de la autoridad de los organismos internacionales para hacer cumplir sus normas.

Sabemos que el derecho internacional es el derecho de la "comunidad de los Estados". El mismo Estado con sus propias normas, incluso las de rango constitucional, se compromete a respetarlo. El derecho internacional regula las "relaciones entre Estados" y tiende a disciplinar materias atinentes a las relaciones interindividuales, es decir, relaciones internas de las comunidades estatales. La vida moderna está dominada por el internacionalismo; es cada vez más un derecho destinado a ser administrado y aplicado por los operadores jurídicos internos, en primer lugar por los jueces nacionales (Benedetto Conforti, Derecho Internacional, 1995, pág. 14).

Nuestra base juridical para fundar el presente trabajo, será que “el Estado tiene la obligación de traducir y garantizar su efectividad en normas internas las normas internacionales". Los Tratados tienden a regular muchas relaciones de la vida social, relaciones que trascienden casi todos los límites y las posibilidades del Estado individualmente considerado; pero no olvidamos que el acuerdo internacional está subordinado a la costumbre -fuente primaria del derecho internacional-.

Las organizaciones internacionales generalmente no tienen poderes vinculantes respecto de los Estados miembros; emiten normalmente recomendaciones que tienen carácter de una mera exhortación, sin embargo existen casos en los que promulgan decisiones vinculantes. El Estado miembro está obligado a cumplirlas dado que se comprometió a respetarlas en virtud del acuerdo constitutivo de la organización. Un ejemplo de ello es nuestra Constitución Nacional de 1853 con la reforma del año 1994, por la que se prevé la posibilidad de que el Estado argentino participe de sistemas de integración aceptando que las normas secundarias creadas por órganos internacionales de integración sean directamente aplicables en el ordenamiento interno, con rango superior al de las leyes de la Nación.

Para asegurar coactivamente la observancia de las normas como para reprimir sus violaciones, los medios con que cuenta el derecho internacional para reaccionar integran casi todos la "autotutela". Muchos piensan que no hay medios para obligar a los Estados a respetar las normas internacionales. Pero la teoría Idealista otorga respuestas que en lo jurídico vemos que se cumplen en la realidad. Los primeros operadores jurídicos internos que tienen la tarea de aplicar y hacer respetar el Derecho, en primer lugar, son los jueces, por lo que el derecho internacional deberá de acuerdo a nuestro ordenamiento estatal, ser aplicado y controlado como el derecho interno. 
El Derecho Internacional se dirige al Estado-organización, debe éste respetar dichas normas y ejercer su poder efectivamente sobre una comunidad territorial, esto es esencial pues los "gobiernos que no gobiernan" no tienen intereses relevantes que administrar en el plano internacional (Conforti, 1995, pág. 26).

Pasando al tema de las organizaciones internacionales, éstas son sujetos diferentes de los Estados miembros, con personalidad propia y fue afirmada por la Corte Internacional de Justicia en la opinión del 20-12-1980 sobre la interpretación del acuerdo del 23-3-1951 entre la Organización Mundial de la Salud y Egipto donde expresa "La organización internacional es un sujeto de derecho internacional, vinculado, en cuanto tal, por todas las obligaciones que se derivan de las reglas generales del derecho internacional, de su tratado constitutivo y de los acuerdos de los cuales forma parte".

El Tratado que da vida a una organización internacional la habilita a emanar decisiones que son vinculantes para los Estados miembros. Según lo prescriban los respectivos estatutos, las resoluciones de las organizaciones internacionales normalmente podrán ser adoptadas por mayoría, incluso calificada. La práctica del consensus consiste en aprobar una resolución sin una votación formal, generalmente con una declaración (no protestada, incluso concertada) del presidente del órgano que certifica el acuerdo entre los miembros, lo que obtiene el compromiso de los Estados miembros respecto de las resoluciones de los órganos internacionales.

Y en materia de Derechos Humanos, los derechos que los Estados están obligados a reconocer a todos los individuos sometidos a su poder sobre la base de Pactos o Tratados es una verdadera obligación que genera responsabilidad internacional. De ahí que la fuente primordial del derecho internacional de los derechos humanos sean además de la costumbre que alberga los principios generales del derecho, las Convenciones suscriptas entre los Estados miembros de las organizaciones internacionales como sucede con Argentina, Costa Rica, en el caso Americano y con España, Francia, por ejemplo en el caso europeo (sujetos éstos últimos a los Tratados de la Comunidad Económica Europea), de las que hablaremos más adelante. Los Tratados de Derechos Humanos encuentran el fundamento de su obligatoriedad en la norma consuetudinaria pacta sunt servanda. También los actos de las organizaciones son fuente derivadas de los Tratados. 
Los Estados nunca han puesto en duda la intangibilidad y la superioridad de los principios contenidos en la Carta de las Naciones Unidas, por ejemplo, y el "respeto de los principios de la Carta" es considerado como una de las reglas fundamentales de la vida de relación internacional y en ese sentido es objeto de solemnes declaraciones de los Estados (Conforti, 1995, pág. 248).

La observancia del derecho internacional pasa por las normas, existentes en casi todos los ordenamientos jurídicos estatales por las que se procede a adaptar el derecho interno al derecho internacional. La observancia y verificación (que es la aplicación misma del derecho internacional) es confiada en primer lugar a los agentes jurídicos -los jueces nacionales- y en especial a los órganos estatales del Estado. Una posición mayoritaria considera que son sumamente escasos e imperfectos los medios de que dispone la comunidad internacional para obligar a un Estado a observar el derecho internacional en sus relaciones mutuas o para obtener una satisfacción cuando ha sido violado un derecho suyo, como así también los medios de verificación judicial que existen en el plano internacional. Considero que las grandes potencias que han dominado las relaciones internacionales en la época de la post Guerra fría han ayudado a que se tenga dicha percepción.

Una vez introducidas en el ordenamiento interno, las normas internacionales de derechos humanos son fuente de derechos y obligaciones para los órganos estatales y para todos los sujetos públicos y privados que actúan dentro del Estado, al mismo nivel que cualquier norma de origen nacional, incluso constitucional después de la reforma del año 1994 en Argentina. Tomemos el ejemplo de la decisión de la Corte Suprema de Justicia de la Nación en el caso Fibraca donde delimita los alcances de sus argumentos expresados en el caso Ekmekdjian al reiterar la primacía de un tratado por sobre las leyes de la Nación (antes de la reforma de 1994), pero esta vez teniendo en cuenta la adecuación del tratado a los principios de orden público constitucional. Esta posición de la Corte confirmaría el principio expresado antes de que el derecho internacional reenvía al derecho interno para la determinación, tanto de los mecanismos de incorporación o adaptación de los tratados, como de su rango o jerarquía dentro del ordenamiento jurídico de cada Estado. Nuestra Corte Suprema ha sostenido que las cuestiones de orden internacional vinculadas a la aplicación de los tratados en el derecho interno del Estado son ajenas, en principio, a la jurisdicción de los tribunales de justicia internos; a partir de la reforma de 1994, el art. 75 inc. 22 de la Constitución establece la superioridad jerárquica de los tratados por sobre las leyes de la Nación. 
Por lo tanto, el valor de la autoridad de las normas emanadas de los organismos internacionales (universal y regional) resulta de sus actos jurídicos como actas de asambleas, cartas de constitución, tratados de derechos humanos, incluso sus resoluciones, y por supuesto de sus sentencias jurisdiccionales, cuando los Estados Partes al suscribir los mismos dan su consentimiento para someterse a la jurisdicción internacional. Y expresamente establecen sus normas dicha obligatoriedad bajo el principio de respeto por la buena fe que debe imperar en su cumplimiento. Por ello, son importantes para nuestro trabajo las observaciones hechas a nuestro país por los organismos de derechos humanos que protegen los derechos de las mujeres (Ejemplo: CEDAW) que transcribimos y señalamos en otro capítulo como fundamento de nuestra Tesis. Por su obligatoriedad, señala responsabilidad del Estado Argentino si ha omitido su cumplimiento en la aplicación efectiva de las normas internacionales sobre -en nuestro caso- el acoso sexual laboral. De hecho las observaciones que más adelante redactaremos, tienen que ver con omitir su implementación. Seguidamente hablaremos de lo que debió implementar el Estado Argentino, pero que se terminó cristalizando como una norma interna basada en los Tratados Internacionales del art. 75 inc. 22 de la Constitución Nacional (C.N) por acción de un particular, la Ley provincial n ${ }^{\circ} 12.764$.

\subsection{LEY PROVINCIAL $\mathrm{N}^{\circ}$ 12.764: REAL APLICACIÓN DEL DERECHO INTERNACIONAL DE LOS DH.}

La única norma interna que contiene disposiciones de orden internacional, cuyo campo de acción se halla limitado a la administración pública de la provincia de Buenos Aires -quedando por ende el ámbito privado a la espera de la sanción de una ley nacional, aunque no sin protección pues se puede recurrir por diversas normas constitucionales y laborales- en su breve articulado, aunque no menos disvaliosa por ello, ha quedado redactada del siguiente modo luego de ser modificada en aspectos significantes (como reglas de procedimiento, etcétera) ajenos a nuestra voluntad:

"El Senado y Cámara de Diputados, etc.

Art. $1^{\mathrm{o}}$ : Todo funcionario $\mathrm{y} / \mathrm{o}$ empleado de la provincia tiene prohibido ejercer sobre otro las conductas que esta Ley tipifica como acoso sexual.

Art. $2^{\circ}$ - Se entiende por acoso sexual el accionar de los funcionarios y/o empleados públicos que valiéndose de su posición jerárquica o de circunstancias vinculadas con su 
función, incurran en conductas que tengan por objeto cualquier tipo de acercamiento sexual no deseado por la persona a quien va dirigido, requerimiento de favores sexuales y cualquier otra conducta verbal o física de naturaleza sexual, cuando se da una o más de las siguientes circunstancias:

a) Cuando someterse a dicha conducta se convierte de forma implícita o explícita en un término o condición de empleo de una persona.

b) Cuando el sometimiento o rechazo a dicha conducta por parte de la persona se convierte en fundamento para la toma de decisiones en el empleo o respecto del empleo que afectan a esa persona.

c) Cuando esa conducta tiene el efecto o propósito de interferir de manera irrazonable con el desempeño del trabajo de esa persona o cuando crea un ambiente laboral de abuso, intimidante, hostil u ofensivo.

Art. $3^{\circ}$ : -El incumplimiento de la prohibición establecida en el artículo $1^{\mathrm{o}}$ de esta ley, será causal de una sanción de orden correctivo, que podrá implicar apercibimiento o suspensión de hasta 60 días corridos. Salvo que por su magnitud y gravedad pueda encuadrarse en la figura de cesantía, exoneración o ser considerado falta grave, según el régimen disciplinario de que se trate. En la instrucción del sumario respectivo se deberá garantizar el carácter confidencial de la denuncia.

Art. $4^{\circ}$ - Comuníquese al Poder Ejecutivo."

Es de destacar en primera medida el objetivo finalmente alcanzado que tuvimos en mira al pretender la existencia de una ley de este tipo, cual era que se pudiera sancionar conductas de funcionarios no sólo de empleados administrativos. Esto es de una gran importancia, pues se puso en práctica el respeto por los derechos humanos y el principio del art. 16 de la C.N sobre la igualdad ante la ley. Es la única norma que trata este aspecto en todo el país.

Vemos que esta Ley no sólo comprende un tipo de acoso sexual, el llamado tradicional, es decir, aquél vinculado al ejercicio del poder, que requiere que el accionar del funcionario ocurra "con motivo o en ejercicio de sus funciones", sino también el llamado "ambiental o intimidatorio". Tampoco exige el rechazo por la víctima, sólo que ella no lo haya deseado, y que ésta además podría haber padecido un acceso carnal (en sus diversas formas aceptadas) y formular su denuncia alegando incluso haber sido seducida o bien que se vio forzada a tal sumisión por temor reverencial.

Sabemos que el otro tipo de acoso sexual que acepta la doctrina, es el denominado "ambiental o intimidatorio" ya sea por producirse en un lugar de trabajo bajo 
condiciones de solicitaciones o incitaciones sexuales importunas o bien de otras manifestaciones verbales, no verbales o físicas de naturaleza sexual, con la finalidad o el efecto de coartar sin razón la actuación laboral de una persona o de crear un entorno de trabajo ofensivo, hostil, de intimidación o de abuso, en muchos casos para lograr que abandone el empleo. "Tales manifestaciones pueden ser efectuadas por el empleador o sus agentes representativos, pero en este acto de amenaza o de presión para conseguir favores de naturaleza sexual, en su interés o en el de terceros. Tambien conforme a lo expuesto, y es lo habitual en estos casos, se encuentra el acoso cumplido por compañeros de trabajo, que contribuyen a crear el ambiente hostil referido con la finalidad ya apuntada"(Martínez Vivot, Julio J., Acoso sexual en las relaciones laborales, pág.23).

\subsection{LEY DE PROTECCION INTEGRAL A LAS MUJERES}

Seguidamente daremos a continuación la normativa existente a nivel nacional en Argentina a los fines de verificar la aplicación de los Tratados relativos a nuestro tema de estudio. Veremos aquí que en la Ley $\mathrm{n}^{\circ} 26.485$ y su decreto reglamentario 1011/2010, se establecen las obligaciones internacionales de impulsar normas (adecuar la legislación interna) y políticas públicas que son necesarias para verificar si se cumple efectivamente su contenido, controlar y exigir su cumplimiento, aunque en los hechos sea diferente.

A)Decreto 1011/2010. Apruébase la reglamentación de la Ley $N^{\circ} 26.485$ que refiere a la protección integral para Prevenir, sancionar y erradicar la violencia contra las mujeres en los ámbitos en que desarrollen sus relaciones interpersonales. Bs. As., 19/7/2010 VISTO el Expediente del Registro de la SECRETARIA GENERAL de la PRESIDENCIA DE LA NACION $\mathrm{N}^{\mathrm{o}} 28.730 / 10$, la Ley $\mathrm{N}^{\mathrm{o}} 26.485$, y CONSIDERANDO: Que tanto la Convención sobre Eliminación de todas las Formas de Discriminación contra la Mujer (CEDAW, 1979), como la Convención Interamericana para Prevenir, Sancionar y Erradicar la Violencia contra la Mujer (Convención de Belem do Pará, 1994), aprobadas por el Estado Argentino por las Leyes Nros. 23.179 y 24.632, respectivamente, obligan a los Estados a impulsar normas y políticas a fin de prevenir y erradicar la violencia contra las mujeres. 
Art. $5^{\circ}$.-Incisos 1) y 2).- Sin reglamentar

Inciso 3).- A los efectos de la aplicación del presente inciso deberá atenerse a lo dispuesto en el artículo $2^{\circ}$ de la Convención Interamericana para Prevenir, Sancionar y Erradicar la Violencia contra la Mujer, conforme la cual la violencia contra las mujeres incluye, junto con la física y la psicológica, a la violencia sexual y se refiere tanto a las acciones o conductas que tengan lugar dentro de la familia, como a las que se produzcan en lugares de trabajo, instituciones educativas, establecimientos de salud o en otros espacios, tanto del ámbito público como del privado. Se tendrá en cuenta lo dispuesto por las normas relativas a la Prevención y Sanción de la Trata de Personas y Asistencia a sus Víctimas - Ley No 26.364.

Art. $6^{\circ}$.- Las definiciones de violencia comprendidas en el artículo que se reglamenta, en ningún caso pueden interpretarse en sentido restrictivo ni taxativo, como excluyentes de hechos considerados como violencia contra las mujeres por otras normas. Para ello deberá interpretarse la norma de forma armónica y sistemática con lo establecido en el artículo $4^{\circ}$, segundo párrafo de la Ley $\mathrm{N}^{\mathrm{o}} 26.485$, y con lo dispuesto en la Convención Interamericana para Prevenir, Sancionar y Erradicar la Violencia contra la Mujer; la Convención sobre Eliminación de todas las Formas de Discriminación contra la Mujer; la Recomendación General No 19 del Comité para la Eliminación de la Discriminación contra la Mujer; los demás Tratados Internacionales de Derechos Humanos y las observaciones y recomendaciones que efectúen sus respectivos órganos de aplicación.

\section{TITULO II-POLITICAS PUBLICAS-CAPITULO I-PRECEPTOS RECTORES}

Art. $7^{\circ}$.- Todas las intervenciones que se realicen en el marco de la presente reglamentación deben garantizar un amplio acceso a la justicia y a los diversos programas y acciones de garantías de derechos contemplados por la ley que se reglamenta. La asistencia a las mujeres en situación de violencia será articulada con todos los organismos intervinientes y evitará su revictimización. Se prestará especial atención a las particularidades o características diferenciales que agraven el estado de vulnerabilidad de las mujeres víctimas, tales como la edad, la condición socioeconómica, el origen étnico, racial o religioso.

Inciso ñ).- El CONSEJO NACIONAL DE LAS MUJERES elaborará una Guía de Servicios de Atención de Mujeres Víctimas de Violencia de todo el país, que será permanentemente actualizada en conjunto con las jurisdicciones locales. Contará con una base de datos en soporte electrónico y cualquier otro medio que permita la consulta 
en forma instantánea y ágil de acuerdo a los requerimientos y a las distintas alternativas disponibles en cada localidad.

Inciso o).- Se implementará una línea telefónica con alcance nacional, sin costo para las/os usuarias/os y que funcionará las VEINTICUATRO (24) horas de todos los días del año.

Art. 11 Inciso 7).- El MINISTERIO DE DEFENSA tomará en consideración las recomendaciones del Consejo de Políticas de Género que funciona en su órbita, a los fines de realizar las propuestas sobre las acciones referentes a la temática a ser desarrolladas por la institución.

Art. 16 Inciso b).- La respuesta que den los organismos del ESTADO NACIONAL será considerada oportuna cuando implique la sustanciación del proceso más breve, o la adecuación de los procesos existentes para que la resolución de los mismos no sea tardía; y efectiva cuando dicha respuesta provenga de la reiteración de hechos de violencia y repare a la víctima en sus derechos, teniendo en consideración las características de la denuncia.

Inciso k).- Los mecanismos de denuncia a los/ as funcionarios/as se consideran eficientes cuando, impidiendo la revictimización de la mujer, evitan una excesiva burocratización de la situación, garantizando un fácil acceso a dicho mecanismo, la inmediata atención y la resolución en plazos razonables del "planteo".

B) "Convención Interamericana para prevenir, sancionar y erradicar la violencia contra la mujer o "Convención de Belém do Pará” (Adoptada en Belém do Pará, Brasil, el 9 de junio de 1994, en el vigésimo cuarto período ordinario de sesiones de la Asamblea General)":

Antes de transcribir las partes más importantes que hacen a nuestra investigación, destacamos que es la única Convención que habla del Acoso Sexual Laboral, aunque sólo lo menciona en el art. $2^{\circ}$ inc. b), como parte de la violencia contra la mujer, y no lo trata específicamente con criterio de caracterizarlo por encima de las otras formas de violencia, pero a nivel internacional es lo único que encontramos, salvo asimismo la mención en la Ley Nacional n 26.485 de "acoso" en la faz interna de Argentina, no existe otro instrumento que lo trate independientemente de otras figuras. 
Establece además las obligaciones del Estado Parte firmante, y destacamos la de debida diligencia que tratamos en el Capítulo III $^{\circ}$.

“Art. 2 Se entenderá que violencia contra la mujer incluye la violencia física, sexual y psicológica: ... b. que tenga lugar en la comunidad y sea perpetrada por cualquier persona y que comprende, entre otros, violación, abuso sexual, tortura, trata de personas, prostitución forzada, secuestro y acoso sexual en el lugar de trabajo, así como en instituciones educativas, establecimientos de salud o cualquier otro lugar, y c. que sea perpetrada o tolerada por el Estado o sus agentes, donde quiera que ocurra. Art. 7: Adoptar políticas orientadas a prevenir, sancionar y erradicar dicha violencia. a. abstenerse de cualquier acción o práctica de violencia contra la mujer y velar porque las autoridades, sus funcionarios, personal y agentes e instituciones se comporten de conformidad con esta obligación;

b. actuar con la debida diligencia para prevenir, investigar y sancionar la violencia contra la mujer;

c. incluir en su legislación interna normas penales, civiles y administrativas, así como las de otra naturaleza que sean necesarias para prevenir, sancionar y erradicar la violencia contra la mujer y adoptar las medidas administrativas apropiadas que sean del caso;

d. adoptar medidas jurídicas para conminar al agresor a abstenerse de hostigar, intimidar, amenazar, dañar o poner en peligro la vida de la mujer de cualquier forma que atente contra su integridad o perjudique su propiedad;

e. tomar todas las medidas apropiadas, incluyendo medidas de tipo legislativo, para modificar o abolir leyes y reglamentos vigentes, o para modificar prácticas jurídicas o consuetudinarias que respalden la persistencia o la tolerancia de la violencia contra la mujer;

f. establecer procedimientos legales justos y eficaces para la mujer que haya sido sometida a violencia, que incluyan, entre otros, medidas de protección, un juicio oportuno y el acceso efectivo a tales procedimientos;

g. establecer los mecanismos judiciales y administrativos necesarios para asegurar que la mujer objeto de violencia tenga acceso efectivo a resarcimiento, reparación del daño $\mathrm{u}$ otros medios de compensación justos y eficaces, $\mathrm{y}$

h. adoptar las disposiciones legislativas o de otra índole que sean necesarias para hacer efectiva esta Convención. 
Artículo 8: Adoptar, en forma progresiva, medidas específicas, inclusive programas para:

a. fomentar el conocimiento y la observancia del derecho de la mujer a una vida libre de violencia, y el derecho de la mujer a que se respeten y protejan sus derechos humanos; b. modificar los patrones socioculturales de conducta de hombres y mujeres, incluyendo el diseño de programas de educación formales y no formales apropiados a todo nivel del proceso educativo, para contrarrestar prejuicios y costumbres y todo otro tipo de prácticas que se basen en la premisa de la inferioridad o superioridad de cualquiera de los géneros o en los papeles estereotipados para el hombre y la mujer que legitiman o exacerban la violencia contra la mujer;

c. fomentar la educación y capacitación del personal en la administración de justicia, policial y demás funcionarios encargados de la aplicación de la ley, así como del personal a cuyo cargo esté la aplicación de las políticas de prevención, sanción y eliminación de la violencia contra la mujer;

d. suministrar los servicios especializados apropiados para la atención necesaria a la mujer objeto de violencia, por medio de entidades de los sectores público y privado, inclusive refugios, servicios de orientación para toda la familia, cuando sea del caso, y cuidado y custodia de los menores afectados;

e. fomentar y apoyar programas de educación gubernamentales y del sector privado destinados a concientizar al público sobre los problemas relacionados con la violencia contra la mujer, los recursos legales y la reparación que corresponda;

f. ofrecer a la mujer objeto de violencia acceso a programas eficaces de rehabilitación y capacitación que le permitan participar plenamente en la vida pública, privada y social; g. alentar a los medios de comunicación a elaborar directrices adecuadas de difusión que contribuyan a erradicar la violencia contra la mujer en todas sus formas y a realzar el respeto a la dignidad de la mujer;

h. garantizar la investigación y recopilación de estadísticas y demás información pertinente sobre las causas, consecuencias y frecuencia de la violencia contra la mujer, con el fin de evaluar la eficacia de las medidas para prevenir, sancionar y eliminar la violencia contra la mujer y de formular y aplicar los cambios que sean necesarios, y i. promover la cooperación internacional para el intercambio de ideas y experiencias y la ejecución de programas encaminados a proteger a la mujer objeto de violencia. 
Art. 9: los Estados Partes tendrán especialmente en cuenta la situación de vulnerabilidad a la violencia que pueda sufrir la mujer en razón, entre otras, de su raza o de su condición étnica, de migrante, refugiada o desplazada. En igual sentido se considerará a la mujer que es objeto de violencia cuando está embarazada, es discapacitada, menor de edad, anciana, o está en situación socioeconómica desfavorable o afectada por situaciones de conflictos armados o de privación de su libertad”.

\subsection{LEGISLACIÓN VIGENTE EN ARGENTINA ANTES DE LA SANCIÓN DE LA LEY PROVINCIAL}

\section{1)Proyecto Tejedor-Código de Faltas:}

Básicamente en cuanto a antecedentes en nuestro derecho interno, nos remontamos hasta el año 1877, en el Proyecto Tejedor adoptado para la provincia de Buenos Aires como código penal en dicho año, en su art. 383 incs. 16 y 17 y en el código penal de 1886, art. 243 incs. 9 y 10 que reprimen al funcionario público que "seduce" a la mujer que litiga ante él, y al que lo hace con una mujer "detenida o sentenciada", que está a su cargo. También incluyen en la protección a la hija de aquélla. Sin embargo en la redacción del código de 1921 esas disposiciones fueron excluídas.

El reglamento de faltas de la Capital Federal de 1932 lo regula como "falta de respeto a la mujer". En tanto en la provincia de Buenos Aires, el código de faltas de 1973, lo hace como "ofensa a la decencia pública”.

\section{2) Decreto Nacional no $2385 / 93$ :}

En el ámbito de la administración pública el decreto incorporó la figura del acoso sexual a la reglamentación del Régimen Jurídico Básico de la Función Pública en el capítulo Deberes y Prohibiciones para el personal de la administración pública central, como segundo párrafo del inciso e) del art. 28.

El texto dice: “Aclárase por coacción de otra naturaleza, entre otros, el acoso sexual, entendiéndose por tal el accionar del funcionario que con motivo o en ejercicio de sus funciones se aprovechare de una relación jerárquica induciendo a otro a acceder a sus requerimientos sexuales, haya o no acceso carnal. Las denuncias o acciones que corresponda ejercer con motivo de la presunta configuración de la conducta antes 
descripta podrán ejercitarse conforme el procedimiento general vigente o, a opción del agente, ante el responsable del área recursos humanos de la jurisdicción respectiva".

Prevé el acoso quid pro quo, pero no el ambiental u horizontal, no hay sanción en el caso de acoso por compañeros de trabajo y se critica la acción de "inducir".

\section{3) Decreto Nacional no 66/99 (29/1/1999):}

Primer Convenio Colectivo de Trabajo del Sector Público -Título XIV de la Igualdad de Oportunidades y de Trato: Capítulo III: Erradicación de la Violencia Laboral: ...”ARTICULO 137.- Los agentes que incurran con su accionar en la figura de acoso sexual, quebrantando las prohibiciones del inciso e) del artículo 28 del Régimen Jurídico Básico, o la norma que lo reemplace en el futuro, serán sancionados con cesantía de acuerdo a lo normado en el artículo 32, inciso f) del mismo ordenamiento legal. La agente afectada por el accionar descripto en el párrafo precedente, podrá denunciar los hechos ante el responsable del área de recursos humanos del organismo. Dicho funcionario, luego de verificar la relación jerárquica existente entre denunciante y denunciado procederá a informar de modo confidencial al funcionario de rango no inferior a Subsecretario del organismo que tenga competencia en el área de sumarios, a fin de que disponga las instrucciones sumariales pertinentes."... Mediante el decreto $\mathrm{N}^{\circ}$ 66/99, se homologó el 1er. Convenio Colectivo de Trabajo del Sector Público. Esto fue el 29 de enero de 1999, se incorporó el título de la Igualdad de Oportunidades y de Trato y en el Capítulo III, Artículo N 137 -ERRADICACION DE LA VIOLENCIA LABORAL -. Como vemos se habla de Acoso Sexual, un tipo de Violencia, y esto fue porque ya existía el decreto que sancionaba esta conducta. Es el primer Convenio Colectivo de Argentina que lo menciona.

\section{4) Ordenanza 47.506,A.D. 230/57:}

Debemos destacar ahora la existencia asimismo de otra norma aunque abarca exclusivamente la Municipalidad de la Ciudad de Buenos Aires, que ha incorporado el acoso sexual como falta sancionable en el régimen disciplinario aplicable a su personal. Se trata de la Ordenanza 47.506, A.D. 230/57, publicada en el Boletín Municipal el 17/1/94. Por la misma “incorpórase el acoso sexual como causa de sanción o cesantía en 
los capítulos relativos al régimen disciplinario incluídos en los diferentes estatutos de personal de la Municipalidad y organismos descentralizados".

\section{5) Ley 25.087:}

Vemos positivamente que se haya modificado la ley penal, aunque es ambigua la interpretación que lleva a disentir en doctrina si se reconoce o no la protección contra el acoso sexual en el siguiente artículo, donde se refiere al abuso sexual, cuando hay una relación de poder, de autoridad, de dependencia:

“Art. 1: Sustitúyese la rúbrica del Título III del Libro Segundo del Código Penal "Delitos contra la honestidad" por el de "Delitos contra la integridad sexual". 2. Deróganse las rúbricas de los capítulos II,III, IV y V del Título III del Libro Segundo del Código Penal.

Art. 20: Sustitúyese el artículo 119 del Código Penal, por el siguiente texto: "Será reprimido con reclusión o prisión de seis meses a cuatro años el que abusare sexualmente de persona de uno $u$ otro sexo cuando, ésta fuera menor de trece años o cuando mediare violencia, amenaza, abuso coactivo o intimidatorio de una relación de dependencia, de autoridad, o de poder, o aprovechándose de que la víctima por cualquier causa no haya podido consentir libremente la acción. La pena será de cuatro a diez años de reclusión o prisión cuando el abuso por su duración o circunstancias de su realización, hubiere configurado un sometimiento sexual gravemente ultrajante para la víctima. La pena será de seis a quince años de reclusión o prisión cuando mediando las circunstancias del primer párrafo hubiere acceso carnal por cualquier vía....”.

6) SIN EMBARGO: antes de la existencia de la Ley provincial contra el acoso sexual laboral en la administración pública, existieron normas que ya actuaban de modo directo o indirecto en defensa de quien había sido víctima del mismo, y que era posible invocar en nuestro derecho interno para exigir la protección debida por el Estado:

a) La Constitución Nacional: Art. 14 (derecho a trabajar, a peticionar a las autoridades), Art. 14 bis expresa la necesidad de que se le aseguren al trabajador "condiciones dignas y equitativas de labor" frase que al decir de Sagués: "la frase constitucional aludida asegura que cualquier vínculo de trabajo debe ser respetuoso de la dignidad del trabajador, sin admitir, por tanto situaciones de hecho que puedan provocar algún desmedro físico o moral o atenten contra la calidad humana del trabajador". Asimismo el art. 75 inc. 22 dispone que determinados tratados y convenciones tienen jerarquía 
constitucional y que debe entendérselos como complementarios de los derechos y garantías establecidos en su Primera Parte por la propia Constitución Nacional y entre éstos específicamente nos interesa la Declaración Universal de Derechos Humanos y la Convención sobre la Eliminación de todas las formas de Discriminación contra la Mujer. Otro inciso posterior, el 23, le confiere al Congreso la facultad de legislar y promover medidas de acción positiva, que garanticen la igualdad real de oportunidades y de trato y el pleno goce de los derechos reconocidos por esta Constitución y los tratados internacionales vigentes sobre derechos humanos respecto de las mujeres. Art. 16 (igualdad ante la ley), 17 (la propiedad es inviolable), 18 (debido proceso legal).Constitución de la Pcia. de Buenos Aires: arts. 10, 11, 12, 14, 15, 25, 27, 31, 36 inc. 4), 39 (incs. $1^{\circ}$ y 4), 103 incs. 8 y 12, todos éstos refiriéndose especialmente al derecho a la vida, al trabajo, al patrimonio, a la no discriminación por razones de sexo, a la igualdad de oportunidades, a la igualdad ante la ley, a peticionar justicia, y a la responsabilidad de los funcionarios públicos.

b) Tratados internacionales con jerarquía constitucional:

La Declaración Americana de los Derechos y Deberes del Hombre (IX Conferencia Internacional Americana Bogotá, 1948. Decreto Ley 9983/57); La Declaración Universal de Derechos Humanos (Asamblea ONU, 16- 12-1948); la Convención Americana sobre Derechos Humanos (Pacto de San José de Costa Rica, 1969. Ley 23054); el Pacto Internacional de Derechos Económicos, Sociales y Culturales (Asamblea general de la UN del 16-12-1966. Ley 23.313); el Pacto Internacional de Derechos Civiles y Políticos y su Protocolo Facultativo (Asamblea general de la UN del 16-12-1966. Ley 23.313); la Convención sobre la Prevención y la Sanción del Delito de Genocidio (Asamblea general de la UN del 9-12-1948. Ley 6286/56); la Convención Internacional sobre la Eliminación de todas las Formas de Discriminación Racial (Asamblea general de la UN del 21-12-1965. Ley 17.722); la Convención sobre la Eliminación de todas las Formas de Discriminación contra la Mujer (Asamblea general de la UN del 18-12-1970. Ley 23.179); la Convención contra la Tortura y otros Tratos o Penas Crueles, Inhumanos o Degradantes (Asamblea general de la UN del 10-12-1984. Ley 23.338); la Convención sobre los Derechos del Niño (Asamblea general de la UN del 20-12-1989. Ley 23.849). 
c) Otras Convenciones- Conferencias: Conferencia Internacional de Mujeres de Naciones Unidas de Viena sobre Derechos Humanos de 1993; Convención interamericana para prevenir, sancionar y erradicar la violencia contra la mujer "Convención de Belém do Pará" (9/6/94); Declaración y Plataforma de acción de Beijing, 4 al 15 de Septiembre de 1995.

d) Legislación Laboral: Cuando el acoso sexual se da en un ámbito laboral, coincidimos con el Dr. Humberto Quiroga Lavié en cuanto a que si "el derecho de trabajar es la facultad de todo individuo a elegir la actividad que le servirá como medio de subsistencia (con base en el art. 14 de la C.N) y el derecho subjetivo de todo trabajador en relación de dependencia a exigirle al empleador el cumplimiento de prestaciones de carácter social e irrenunciable, establecidas por la Constitución o por las leyes (con base en el art. 14 bis de la C.N.). ...La libertad de trabajo implica la libertad de profesión, que es "cualquier trabajo de naturaleza económica que asegure la base de la propia vida" (E.Stein).... Los derechos del art. 14 bis están dispuestos a favor de todos los trabajadores..." y no sólo en beneficio de los empleados públicos solamente" (Quiroga Lavié, Humberto, Los derechos humanos y su defensa ante la justicia, pág. 299), entonces cabe mencionar las normas que regulan dicha protección: En la ley de contrato de trabajo en materia laboral $n^{\circ} 20.744$, tenemos la protección de sus artículos 17, 62, $65,66,68,69,75,76,81,172$ у 242.

e) Legislación General: Podemos contar con la Ley 23.592 que tutela la dignidad de la persona humana, como bien jurídico protegido.

f) Convenios de la Organización Internacional del Trabajo ratificados: Nuestro país ratificó el Convenio OIT n* 111, para la promoción de igualdad de oportunidades y de trato en materia de empleo y ocupación. Su objetivo es eliminar toda clase de discriminación, entre ellas aquella que opera por sexo.

\subsection{LEGISLACIÓN VIGENTE EN ARGENTINA POR PROVINCIAS ANTES Y DESPUÉS DE LA SANCIÓN DE LA LEY No 12.764 DE LA PCIA. DE BUENOS AIRES}

1) Ley 3307 de la Provincia de Misiones (6/8/1996):

Para el personal de la administración pública aunque limitada al caso del quid pro quo, se incluyó en las prohibiciones para el personal del art. 41 inc. i) en los siguientes términos: "Ejercer coacción sexual, entendiéndose como tal el accionar del 
funcionario, cualquiera sea su sexo, que con motivo del ejercicio de sus funciones solicitare favores sexuales prevaliéndose de una relación jerárquica". También existió la Ley 4.148 para prevenir, controlar, sancionar y erradicar la violencia laboral publicada el 31/8/2005, pero que fuera derogada junto con más de cincuenta leyes por la Ley 4.245 del año 2005 con considerandos que no hacen referencia alguna a ella. Hablaba sobre el Acoso Sexual en su art. $3^{\circ}$, tanto del quid pro quo como del llamado ambiental.

2) Ley 11.948 del 8/11/2001 que modifica el Código de Faltas (Ley 10.703) de la Provincia de Santa Fe:

Agrega el art. 78 bis que prevé la figura del acoso quid pro quo, en tanto el acoso ambiental se prevé en el art. 78. "Artículo 78 bis.- ACOSO SEXUAL. El que como condición de acceso al trabajo, o el que en una relación laboral, utilizando su situación de superior jerarquía, hostigare sexualmente a otro en forma implícita o explícita, siendo esta conducta consentida y ofensiva para quien la sufre y padece, y, siempre que el hecho no configure delito será reprimido con una multa de diez (10) jus y hasta cinco (5) días de arresto, dependiendo la sanción de la gravedad, circunstancias y consecuencias que de los actos se deriven. A los fines del presente artículo, la relación laboral podrá ser acreditada por cualquier medio de prueba." Pero el 4/8/2005 se publica la Ley 12.434 para prevenir, controlar y sancionar la violencia laboral y brindar protección a los trabajadores del Estado (en todas sus formas) víctimas de las mismas, denunciantes, y/o testigos de los actos ilícitos. No define expresamente el acoso sexual.

3) Ley 7.232 para prevenir, controlar, sancionar y erradicar la violencia laboral en el empleo público de la Provincia de Tucumán (publicada el 4/10/2002):

En su art. $4^{\circ}$ se refiere a una de las formas de violencia laboral, el acoso sexual al que no define pero que en su art. 9 podemos ver que se ha querido referir al quid pro quo de un superior jerárquico o tercero vinculado directamente con éste.

4) Ley 5349 sancionada el 22/5/2003 en la Provincia de Jujuy, para prevenir, controlar, sancionar y erradicar la violencia laboral en el ámbito de la administración pública:

En su art. $3^{\circ}$ define la violencia laboral, y entre sus formas, se menciona el acoso sexual el cual define en su art. $7^{\circ}$ "Se entiende por acoso sexual a la conducta reiterada 
de asedio o requerimiento sexual no deseado por la victima". Muy escueto pero implicaría a su vez al quid pro quo y al ambiental.

5) Ley 1225 publicada el 12/1/2004 contra la violencia laboral en la Ciudad Autónoma de Buenos Aires para el ámbito de la administración pública:

Define el acoso sexual quid pro quo y ambiental (aunque solo contempla el llevado a cabo por un superior jerárquico y no por otro agente del mismo nivel) en su art. $6^{\circ}$.

6) Ley 13168 Provincia de Buenos Aires contra la violencia laboral, no define el Acoso Sexual Laboral.

7) Convenio Colectivo de trabajo general del sector público Nacional:

TITULO IX DE LA IGUALDAD DE OPORTUNIDADES Y DE TRATO.... “ARTICULO 124.- Erradicación de la violencia laboral. Las partes signatarias acuerdan en reconocer que la violencia laboral impide la consecución del principio de no discriminación e igualdad de oportunidades, contraponiéndose a los principios éticos que rigen el empleo regulado por el presente convenio, y concuerdan en que ésta se refiere a toda acción, omisión, segregación o exclusión realizada en forma reiterada por un agente que manifieste abuso de la autoridad que le confieren sus funciones, cargo o jerarquía, influencia o apariencia de influencia, que tenga por objeto o efecto la degradación de las condiciones de trabajo susceptibles de afectar los derechos, la dignidad de los trabajadores, de alterar su salud física y mental y/o comprometer su futuro laboral; o al consentimiento de dichas conductas en el personal a su cargo sin hacerlas cesar; pudiendo ser estas acciones de naturaleza sexual o moral, para beneficio propio o de un tercero, bajo las posibles formas de maltrato físico, psíquico o social, acoso u hostigamiento moral, acoso sexual, homofóbico o discriminación por género. La comisión de cualquier acto de violencia laboral configura falta grave en los términos del artículo 32 inciso e) del Anexo a la Ley $\mathrm{N}^{\circ} 25.164$, en virtud de lo previsto en el artículo 37 inciso i) del presente. De manera similar se procederá en los casos del personal comprendido por la Ley de Contrato de Trabajo de conformidad con lo dispuesto en el artículo 242 de dicha norma o la que la sustituya”. Este convenio colectivo fue homologado en febrero del 2006.-

8) Convenio Colectivo para el personal de la Legislatura de la Ciudad Autónoma de Buenos Aires -Título VI de la Igualdad de oportunidades y de trato Capítulo IV Erradicación de la Violencia Laboral. 
“ARTICULO 303․- CONCEPTO. Se entiende por violencia laboral toda acción que manifieste abuso de poder ejercida mediante amenazas, intimidación, amedrentamiento, maltrato, persecución, menosprecio, insultos, bromas sarcásticas reiteradas, discriminación negativa, imposición, hostigamiento, aislamiento, acoso sexual, tareas imposibles de realizar o denigrantes para la condición humana, acciones que en forma reiterada, atenten contra la dignidad, integridad física, sexual, psicológica o social de los trabajadores comprendidos en el presente convenio, sin perjuicio de las conductas definidas por la Ley Nacional N²3.592 y Ley $\mathrm{N}^{\circ} 1225$ (BOCBA N 1855 del 12/01/2004) sus modificatorias y cualquier otra norma referida a lo expresado en el presente artículo". Comprende como vemos, los dos tipos de acoso sexual laboral. Fue homologado en el año 2004.

\subsection{INFORMES A Y DE LOS ORGANISMOS INTERNACIONALES.}

Como hemos dicho anteriormente, ante la falta de información pública y datos que permitan dictaminar sobre el progreso, aplicación y control de las normas que nos preocupan, y falta de estadísticas por el Instituto Nacional de Estadísticas y Censos (INDEC), sobre los fundamentos para probar nuestra hipótesis, debemos recurrir a otras fuentes de información (documental) primero a las políticas públicas que se plasman a través de los informes que eleva Argentina ante el CEDAW, y segundo, aquéllos que organismos de Derechos Humanos especializados de la mujer en la órbita de la Organización de Estados Americanos y/o las Naciones Unidas remiten a Argentina y que dictaminan sobre la falta de esas políticas públicas y de la real aplicación de las normas de derechos humanos que protegen a la mujer.

Y comenzamos así:

$\left.I^{o}\right)$ "Informes de la Comisión Nacional de la Mujer, elevado para su aprobación ante el Comité de Expertas de Violencia de la Organización de Estados Americanos, del año 2000-2001:V INFORME DE LA REPÚBLICA ARGENTINA PERÍODO: desde el 4 de febrero de 2000 hasta el 27 de diciembre de 2001-QUINTO INFORME DE LA REPÚBLICA ARGENTINA. Mecanismo Nacional para la institucionalización del enfoque de Género: Consejo Nacional de la Mujer. Este Quinto Informe de la República Argentina comprende el período que se inicia el 4 de Febrero de 2000 hasta el 27 de diciembre de 2001, bajo la presidencia del Sr. Dr. Fernando De la Rúa. El mecanismo 
nacional para el Adelanto de la Mujer en Argentina fue creado en 1983 con la Dirección de la Mujer, que se ubicó en el ámbito de la Secretaría de Desarrollo Humano y Familia del Ministerio de Salud y Acción Social. En 1987 se transformó en Subsecretaría de la Mujer y en 1992 en el actual Consejo Nacional de la Mujer, directamente dependiente de Presidencia de la Nación (Dec. 1426/92 y 718/92). En 1999 pasó al ámbito de la Jefatura de Gabinete de Ministros (Dec. 943/99 y 2518/99). Este traspaso del CNM a Jefatura de Gabinete de Ministros tiene un efecto muy importante por el espacio otorgado en la Constitución Nacional de 1994 a la Jefatura de Gabinete de Ministros. En primer lugar, la Constitución Nacional de 1994 creó la Jefatura de Gabinete de Ministros como órgano coordinador, con las funciones de ejercer la administración general del país y coordinar las acciones con los demás Ministerios (art. 100 C.N). Esto significa que el hecho que el CNM se inserte y dependa directamente del organismo coordinador de los actos de gobierno amplía el margen para realizar acciones transversales con las diferentes áreas de gobierno. El presupuesto acordado para el año 2000 del CNM fue de 1.800 .000 pesos y para el año 2001 de 2.880.060 pesos. En una primera evaluación económica de la institucionalidad de la organización, podría considerarse que los recursos asignados son insuficientes, sin embargo, es importante señalar que, considerando como central la herramienta de transversalidad para el logro de los objetivos esperados, al monto nominal asignado, debería adicionarse los recursos que aportan las distintas áreas de gobierno (nacional y provincial) y los otros actores sociales con los que el CNM se relaciona en los procesos de producción de resultados. Actualmente se está avanzando en esta evaluación para poder definir la verdadera dimensión de los costos atribuibles a los resultados que evidentemente son de mayor envergadura que los señalados.

Desde el año 2000, el Consejo Nacional de la Mujer de Argentina (CNM), persigue los siguientes objetivos:

- Legitimar ante la sociedad la relevancia de la equidad de género para el fortalecimiento de la democracia.

- Impulsar políticas públicas con perspectiva de género que contribuyan a la superación de las diversas formas de discriminación contra las mujeres y promuevan las condiciones sociales adecuadas para garantizar a las mujeres el ejercicio efectivo de sus derechos.

- Fortalecer las áreas Mujer provinciales y locales e impulsar la articulación de acciones conjuntas a partir del Plan Federal de la Mujer. Las áreas mujer provinciales son 21 y a 
nivel local 240 áreas en todo el país. En esta dirección, las líneas estratégicas establecidas, se pueden resumir de la siguiente manera:

- Impulso y monitoreo del efectivo cumplimiento de las Convenciones Internacionales, ya estén incorporadas o no a la Constitución Nacional de 1994...Justicia: garantizar el acceso a la justicia de la mujer y coordinar acciones para que los organismos públicos asuman su responsabilidad de erradicar la violencia contra la mujer.

- garantizar el cumplimiento efectivo de los tratados internacionales de derechos humanos incorporados a la Constitución Nacional.

- formular políticas públicas desde una perspectiva de género, que contribuyan a superar las diversas formas de discriminación contra las mujeres y promuevan las condiciones sociales adecuadas para garantizarles el ejercicio efectivo de sus derechos".

Sistema Nacional de Información Mujer (SNIM):Su objetivo es desarrollar un sistema de información en el CNM y ponerlo en funcionamiento en las provincias que conformen el programa....Al mes de agosto de 2001 se habían registrado alrededor de 1300 consultas. En la procedencia de las consultas se registra que el $53 \%$ provienen de Capital Federal, un $44 \%$ de la provincia de Buenos Aires y un $3 \%$ corresponde a otras provincias. Del análisis de los datos en función del sexo se obtuvo que el $85 \%$ corresponde a consultas de mujeres, y un $4 \%$ a consultas de varones y el $11 \%$ restante a consultas realizadas por instituciones. De acuerdo al motivo de la consulta se obtuvieron los siguientes resultados: Jurídico 45,58\%-Violencia 22,05\%-Abuso sexual $0,04 \%$-Acoso sexual $0,13 \%$.

Acoso Sexual-Legislación-En 2001 ingresó al Senado de la Nación el Proyecto de Ley sobre Violencia Laboral que fue elaborado en el marco del "Programa Mujer" del Bloque Justicialista del Senado, conjuntamente con la Secretaría de Igualdad de Oportunidades de la Unión del Personal Civil de la Nación. El mismo incluye la figura del Acoso Sexual”.

Elegimos partir del presente informe a los fines de establecer los límites espaciales y temporales para nuestro estudio, el que localizaremos con respecto a la acción estatal entre el año 2000 y 2015. Como resultado tenemos lo siguiente: a) se reconoce por el Estado que los recursos asignados en ese período son insuficientes; b) se impone como obligaciones: garantizar el acceso a la justicia de la mujer y responsabilizar a los organismos públicos, garantizar el cumplimiento efectivo de los 
tratados internacionales de derechos humanos incorporados a la Constitución Nacional y formular políticas públicas desde una perspectiva de género; c) la elaboración de los indicadores de género se realiza a partir de la utilización de estadísticas públicas que existan en el país lo que será importante para nuestra futura conclusión, ya que dependerán entonces de la información que haya realizado el INDEC; d) reconoce que existe al año 2001 un proyecto de ley sobre violencia laboral que incluía al acoso sexual laboral.

Hasta aquí, por la falta de funcionamiento del principal ejecutor de la política pública a nivel nacional, todo quedó en la norma sin proyección real en la práctica.

$\mathrm{II}^{\circ}$ ) “Recomendaciones de CEDAW para la República Argentina. Exámen de los informes de los Estados Parte-IV y V Informes Periódicos 23 de agosto de 2002-Comité para la Eliminación de la Discriminación contra la Mujer-Período Extraordinario de Sesiones 5-23 agosto 2002.-(a) INTRODUCCION DEL ESTADO PARTE:

1- El Comité examinó el Cuarto y Quinto Informes Periódicos de Argentina (CEDAW/C/ARG/4) y (CEDAW/C/ARG/5) en su sesión 584, celebradas el 16 de agosto de 2002 (CEDAW/C/SR.584).

16. El Comité manifiesta su insatisfacción por la falta de información durante el diálogo constructivo sobre el impacto de la crisis en la población femenina del país que incide negativamente en la aplicación de la Convención; por ello el Comité decide solicitar al Estado Parte, en cumplimiento de lo dispuesto en el artículo 18.1. inciso b de la Convención, la presentación de un Informe de seguimiento, en enero de 2004 para que sea analizado por el Comité en junio del 2004.

19. Principales esferas de preocupación y recomendaciones.

20. Preocupa al Comité la situación de las mujeres como resultado del aumento creciente de la pobreza, y la pobreza extrema, que se ha extendido a más de la mitad de la población, y que puede recaer en forma desproporcionada en la población femenina. En especial, preocupan al Comité las mujeres jefas de hogar que viven en la pobreza y se encuentran desocupadas, con hijas e hijos a su cargo, las mujeres de las zonas rurales, de las poblaciones indígenas y de los sectores más vulnerables de la población.

30. El Comité observa con preocupación el intento de desjerarquización institucional del Consejo Nacional de la Mujer, así como la falta de una estrategia formal de articulación y coordinación entre las distintas agencias estatales. PRESENTACIÓN DE LA REPUBLICA ARGENTINA. Exposición de la Representante del Gobierno Nacional, 
Presidenta del Consejo Nacional de la Mujer, Dra. Gloria del Socorro Abán. ... Acoso

Sexual: Proyectos de ley que sancionan el Acoso Sexual para la actividad privada:

En el Congreso Nacional se encuentran actualmente en trámite alrededor de 10 proyectos de Ley que tienen como objetivo sancionar el acoso sexual. Algunos, incorporan modificaciones en la Ley de contrato de trabajo y establecen un régimen de sanciones en el ámbito laboral dentro de la actividad privada. Otros proyectos, en cambio, proponen incluir el acoso sexual dentro de propuestas de modificaciones al Código Penal, extendiéndolo a otro tipo de relaciones, fuera del ámbito laboral. En 2001 ingresó al Senado de la Nación el Proyecto de Ley sobre Violencia Laboral ...El mismo incluye la figura del Acoso sexual. El CNM participa juntamente con la Dirección de la Mujer de la Ciudad de Buenos Aires y organizaciones de la sociedad civil en actividades destinadas a la sanción de una ley de Acoso Sexual en el Congreso Nacional”.

Como se puede apreciar las críticas de la CEDAW apuntan a la falta de información (que es una constante en cada observación a los informes de Argentina) en el caso por la grave crisis económica que afecta a las mujeres pobres y solicita se le informe en la próxima reunión (para el año 2004). Asimismo preocupa al organismo la desjerarquización que sufrirá el Consejo Nacional de la Mujer, que sale de la órbita presidencial directa y pasa a depender del jefe de gabinete de Ministros de la Nación. Nota la falta de coordinación entre agencias estatales lo que significa la falta de organización y puesta en marcha en todo el país de las medidas que prevé la Convención. Y por ultimo señala el Estado Argentino que existen numerosos proyectos de ley, pero preocupa al organismo que no haya sanción de ninguno que prohíba el acoso sexual laboral.

III) "Recomendaciones de la CEDAW. Recomendaciones del Comité para la Eliminación de la Discriminación contra la Mujer (CEDAW) en ocasión de la presentación del Informe de Seguimiento del Quinto Informe Periódico de la República Argentina. Versión oficial:

356. El Comité examinó el informe de seguimiento del quinto informe periódico de la Argentina (CEDAW/C/ARG/5/Add.1) en su 660a sesión, celebrada el 16 de julio de 2004 (véase CEDAW/C/SR.660). Presentación por el Estado Parte--Observaciones 
finales del Comité-Introducción-Principales esferas de preocupación y recomendaciones:

370. Si bien celebra los esfuerzos realizados por el Estado Parte, al Comité le preocupa que el mecanismo nacional para el adelanto de la mujer carezca de recursos financieros y humanos suficientes para la eficaz promoción del adelanto de la mujer y la igualdad entre los géneros en la etapa actual de renovación política, económica y social. Al Comité también le preocupa que el Consejo Nacional de la Mujer tenga un papel limitado en la estructura gubernamental y no forme parte del Gabinete Presidencial.

371. El Comité recomienda que el Estado Parte fortalezca el mecanismo nacional existente a fin de lograr que tenga mayor eficacia como catalizador para la igualdad entre los géneros en todas las esferas de la vida del país, y tanto en el plano federal como en los planos provincial y local, suministrándole un grado suficiente de visibilidad, poder, y recursos humanos y financieros en todos los niveles y mejorando su capacidad para coordinar eficazmente la labor de los mecanismos existentes en los planos nacional y local. Asimismo exhorta al Estado Parte a que fortalezca la capacidad del mecanismo para llevar a cabo con eficacia actividades encaminadas a lograr el adelanto de la mujer y la promoción de la igualdad entre los géneros, y a asegurar que las perspectivas de género se incorporen en todas las políticas y programas.

373. El Comité recomienda que el Estado Parte haga hincapié en el enfoque de potenciación de la mujer e incorpore perspectivas de género en todos sus proyectos, políticas y programas sociales y económicos, de forma de asegurar que apoyen el logro del objetivo de la igualdad entre los géneros y el goce de sus derechos humanos por parte de las mujeres. Invita al Estado Parte a evaluar periódicamente tales medidas, así como su incidencia en las mujeres de forma de asegurar que no perpetúen la discriminación contra la mujer.

378. El Comité expresa su preocupación por el incremento en la incidencia de la violencia contra las mujeres, en particular la violencia doméstica y el acoso sexual en el lugar de trabajo, que puede estar correlacionado con la crisis existente en el país. Al Comité le preocupa asimismo que los autores de actos de violencia escapen con frecuencia al castigo.

379. El Comité insta al Estado Parte a que vele por la aplicación de un enfoque comprensivo en relación con la violencia contra las mujeres y las niñas, teniendo en cuenta su recomendación general 19 sobre la violencia contra la mujer. Dicho enfoque debe comprender la aplicación efectiva de la legislación vigente, a nivel provincial, para 
luchar contra todas las formas de violencia contra las mujeres. Además, el Comité insta al Estado Parte a que considere la posibilidad de sancionar a nivel federal una ley aplicable en todo el territorio del país, con el fin de combatir y erradicar la violencia contra las mujeres y asegurar que las mujeres que son víctimas de la violencia y el acoso sexual tengan acceso a medios de protección y recursos eficaces, y que los autores de tales actos sean efectivamente enjuiciados y castigados, y que las mujeres sean efectivamente protegidas contra las represalias. El Comité recomienda también que el Estado Parte inicie una campaña nacional de sensibilización pública sobre la violencia contra las mujeres y la inaceptabilidad social y moral de dicha violencia, especialmente en el período de dificultades que vive actualmente el país, y que incremente sus esfuerzos por impartir a los funcionarios públicos, en particular el personal encargado de hacer cumplir la ley, el personal del Poder Judicial y los profesionales de la salud, una capacitación sensible a las cuestiones de género en lo tocante a la violencia contra las mujeres, que constituye una violación de los derechos humanos de las mujeres".

Destacamos aquí una vez más la insistencia del organismo especializado que recalca sobre la importancia y gravedad del tema que nos ocupa, señalando que no debe carecer de presupuesto financiero y personal humano capacitado el órgano estatal que asiste a las mujeres víctimas de la violencia y del acoso sexual lamentando a la vez que tenga un papel limitado; insta al Estado a considerar la potenciación de la mujer y la perspectiva de género como política de estado, al incluirla en todos los proyectos, políticas y programas sociales y económicos. Observa el incremento de la violencia familiar sobre la mujer y del acoso sexual laboral y así también la impunidad de los autores de dichas violencias. A la vez se deben aplicar las leyes vigentes para que sean efectivas, dictar una ley para todo el país que prohíba los actos de violencia y acoso sexual, y enjuiciamiento efectivo y condena para los autores de dichos actos. Por último brindar protección a la mujer contra la represalia y capacitar a aquellas personas que cumplen funciones judiciales, de aplicación de la ley y en materia de salud para atender a las víctimas. Como se aprecia, son más las recomendaciones por las faltas en el cumplimiento de los Tratados sobre el tema, que las felicitaciones por dar.

Podemos desde ya afirmar -aunque seguiremos analizando- que no solamente es imprescindible la ley, sino que la misma debe ser asegurada que se aplique, o no hay vigencia sociológica y no habría derechos en el plano material por la omisión del 
Estado en garantizar los mismos.

IV) "Informe de la Comisión Nacional de la Mujer, elevado para su aprobación ante el Comité de Expertas de Violencia de la Organización de Estados Americanos, del año 2005:

a) De la "Evaluación de la Implementación de las Disposiciones de la Convención de Belem Do Pará (2006) COMITÉ DE EXPERTAS/OS VIOLENCIA (CEVI) OEA/Ser.L/II.7.10 MECANISMO DE SEGUIMIENTO MESECVI/CEVI/doc.5/05 rev.1 CONVENCIÓN BELÉM DO PARÁ (MESECVI) 24 agosto 2005, 22-24 agosto 2005 Original: español Washington, D.C. CUESTIONARIO PARA LA EVALUACIÓN DE LA IMPLEMENTACIÓN DE LAS DISPOSICIONES DE LA CONVENCIÓN INTERAMERICANA PARA PREVENIR, SANCIONAR Y ERRADICAR LA VIOLENCIA CONTRA LA MUJER, CONVENCIÓN DE BELÉM DO PARÁ", extraeremos lo que hace a nuestro tema:

"I. Legislación. Normativa vigente. Planes Nacionales

1. ¿Existen en la legislación interna normas penales, civiles y administrativas y de otra indole destinadas a prevenir, sancionar y erradicar la violencia contra la mujer?1.1. ¿Se han promulgado, modificado o derogado leyes y reglamentos en su país a fin de modificar prácticas jurídicas o consuetudinarias que respaldan la persistencia o la tolerancia de la violencia contra la mujer? 1.2. ¿Se han aprobado este tipo de normas después de la ratificación de la Convención Belém do Pará por parte de su Estado? RESPUESTA (RTA) DEL ESTADO: En la legislación interna de la República Argentina existen normas penales civiles y administrativas que tienen como objetivo prevenir, sancionar y erradicar la violencia contra la mujer. En este sentido, después de la ratificación de la Convención de Belém do Pará se sancionaron la gran mayoría de las leyes provinciales de Violencia Familiar, se modificó la legislación penal en el año 1999 y se dictaron distintas disposiciones administrativas...".

Como se ve claramente no menciona en absoluto el acoso sexual en esta parte, aunque luego se refiere a él junto con la violencia laboral exponiendo como ejemplos de normativa al Decreto 2385/93, la Ordenanza N47.506, AD 230-57 BM 17/1/94 de la Ciudad Autónoma de Buenos Aires. También las leyes de las provincias de Buenos Aires, Santa Fe y Misiones. Destaca que en el año 2005 se abre una Oficina Especializada en el ámbito de la Fiscalía Nacional de Investigaciones Administrativas 
para recibir denuncias sobre violencia laboral (incluye acoso sexual) de empleados estatales de la Administración Central, que recibe la denuncia y presenta la acusación.

“1.3 Para el caso de incumplimiento de funcionarios públicos: “e) ¿Existe sanción para los/las funcionarios/as públicos que no cumplen con la aplicación de las leyes de violencia?”. Aquí se responde sintéticamente que no se establecen sanciones en caso de incumplimiento. “g) ¿Existe alguna disposición legal o administrativa que haga obligatoria la capacitación permanente en materia de género para funcionarios públicos? RTA: ....no hay una disposición que lo haga obligatorio para funcionarios públicos”.

"2. ¿Se ha adoptado un plan de acción o una estrategia nacional para prevenir, sancionar y erradicar la violencia contra la mujer?. 2.1. ¿Cuál es el organismo encargado del diseño de dicho plan de acción o estrategia general nacional? 2.2. ¿Cuál es el organismo encargado de la aplicación de dicho plan de acción o estrategia? ¿Existen estrategias intersectoriales integradas? Si existen, ¿qué agencias participan en ellas? 2.3. ¿Se han realizado evaluaciones del plan de acción o estrategias realizadas? Si se han realizado, ¿qué resultados se han obtenido hasta el momento? Si no se han realizado evaluaciones ¿está previsto realizarla? ¿En qué plazo? 2.4. ¿Está prevista una revisión periódica del plan de acción o estrategia en base a los resultados obtenidos en las evaluaciones de su implementación? 2.5. ¿Cómo se articulan las estrategias a niveles provinciales y municipales? RTA: ...c. Se firma en el año 2005 el Convenio Marco de Cooperación Interinstitucional celebrado entre la Secretaría de Seguridad del Ministerio del Interior de la Nación y el Consejo Nacional de la Mujer para la realización conjunta de proyectos de formación, capacitación, investigación, promoción, difusión y desarrollo respecto de problemas de interés común, a fin de promover y hacer efectivos los compromisos asumidos por la Nación Argentina al aprobar la Ley N 23.179 sobre la "Convención sobre la Eliminación de Todas las Formas de Discriminación contra la Mujer" que reviste rango constitucional y la Ley No 24.632 que aprueba la "Convención Interamericana para Prevenir, Sancionar y Erradicar la Violencia contra la Mujer”....d. El CNM desarrolló un Sistema de Información y Monitoreo de la Violencia Familiar Contra la Mujer, diseñando un Instrumento de Registro de Casos y un Programa Informático para el Ingreso y Análisis de Información, con el objetivo de permitir estimar la prevalencia e incidencia de la demanda institucional, es decir, los casos atendidos por los servicios especializados, así como el perfil sociodemográfico de la 
población atendida (antecedentes familiares, motivos de consulta, situación vincular, antecedentes de maltrato, tiempo de exposición a la situación de violencia, etc.)".

Es de resaltar y esto es muy grave, que a la fecha no se reportaron informaciones estadísticas sobre las funciones antedichas.

"3 ¿Se ha establecido un mecanismo a nivel nacional para hacer el seguimiento de la implementación de la Convención Belém do Pará? Si se ha establecido el mecanismo: ¿Cuál es el organismo encargado de hacer su seguimiento a nivel nacional? RTA: El Consejo Nacional de la Mujer es el organismo encargado de velar por el cumplimiento de la Convención sobre la Eliminación de Todas las Formas de Discriminación contra la Mujer y de la Convención de Belem do Pará. En ese marco, el organismo desarrolló un Programa Nacional sobre la temática de violencia y diversas actividades tendientes a monitorear la implementación de la Convención y de las leyes de violencia familiar en el país".

“5. ¿Existen comisiones legislativas especializadas en temas de género?5.1. ¿Cómo opera su funcionamiento en el orden de las legislaturas nacionales? 5.2. ¿Cómo opera su funcionamiento en el orden de las legislaturas provinciales? RTA: Si existen: A nivel de Diputados existe la Comisión de Familia, Mujer, Niñez y Adolescencia. Compete a esta Comisión dictaminar sobre todo asunto o Proyecto relativo a la organización, desenvolvimiento, consolidación y desarrollo de la familia en la comunidad; la protección y orientación de los niños, niñas y adolescentes y lo referente al estado, condición e integración de las mujeres en el conjunto de la sociedad. Asimismo, la Comisión asume el seguimiento permanente del cumplimiento de la Convención sobre los Derechos del Niño y de la Convención sobre la Eliminación de Todas las Formas de Discriminación contra la Mujer. En la gran mayoría de las legislaturas provinciales existen comisiones de Familia, Mujer y Niñez".

Cabe destacar aquí que en todos -o casi todos- los ejemplos anteriores que se refieren a violencia de género, se habla casi exclusivamente de violencia en la familia y no en el lugar de trabajo. De acuerdo con este informe -por su silencio- en Argentina no existen trámites expeditos y normados que garanticen efectivamente la aplicación de las garantías constitucionales en el tema en estudio. Incluso lo reconoce el mismo país cuando dice: "Sobre la violencia a la mujer en el ámbito familiar, en general existe la queja de que los tribunales y/o juzgados de todas las jurisdicciones provinciales competentes para tratar estas denuncias no se corresponden con la cantidad de casos a atender, por falta de espacio y de personal, así como de personal capacitado en la 
temática de género, por lo que existen demoras considerables en la resolución de los casos elevados a la justicia”.

"2.En materia de responsabilidad estatal por la acción u omisión de los funcionarios encargados de cumplir con el servicio de recibir denuncias de violencia contra la mujer, "2. Los/as funcionarios/as encargados/as de atender las denuncias de violencia contra la mujer, ¿cuentan con preparación en materia de perspectiva de género con respecto de la prevención, sanción y erradicación de la violencia? Si la respuesta es afirmativa: 2.1. ¿Se efectúa una supervisión de los/as funcionarios/as encargados/as de atender y dar curso a los procesos sobre violencia contra la mujer? 2.2. ¿Están informados/as de las penas de las que son pasibles en caso de inacción y/o faltas de conducta respecto de los procesos de violencia contra la mujer? 2.3. ¿Los/as funcionarios/as encargados de procesar las denuncias de violencia reciben capacitación en materia de perspectiva de género y sobre prevención, sanción y erradicación de la violencia? RTA: Hay acciones de sensibilización, información y capacitación insuficientes".

Véase la breve respuesta a tan exhaustivo interrogatorio. En este último asume que son insuficientes las acciones que hacen a la promoción de los derechos de las mujeres. Se deja entrever así la falta de implementación en la práctica del material humano necesario para poner en funcionamiento las políticas públicas nacionales. Esto marca incumplimiento y responsabilidad del Estado respecto de las normas internacionales sobre violencia contra la mujer, y mucho más en consecuencia, sobre nuestro tema.

Más interesante es comprobar en el informe que no se dan especificaciones o directamente las respuestas a preguntas sobre los fondos a utilizar para llevar a cabo la acción gubernamental para erradicar la violencia contra la mujer: "III. Presupuesto Nacional.1. ¿Existen partidas en el presupuesto nacional y local destinadas a financiar acciones frente a la violencia contra las mujeres? RTA: Las partidas del presupuesto nacional que se dedican a violencia contra las mujeres integran los fondos destinados a distintos organismos como el Consejo Nacional de la Mujer, los de los Ministerios de Salud y el de los hospitales públicos nacionales y provinciales que atienden estas problemáticas, del Ministerio de Desarrollo Social y de programas que financian proyectos como el PROFAM, el Plan Federal de la Mujer, etc.” 
“1.1. ¿Existen partidas en el presupuesto nacional destinadas al fortalecimiento del ente rector o estrategia nacional sobre violencia contra las mujeres y para el desarrollo del plan nacional sobre la violencia contra las mujeres? ¿En qué monto y porcentaje? 1.2. ¿Cuál es el porcentaje del Producto Interno Bruto que se invierte para prevenir, erradicar y sancionar la violencia contra la mujer? 1.3. ¿Cuál es la inversión anual en dólares destinada a las comisarías de la mujer y/o a la protección policial de mujeres víctimas de violencia, su familia y testigos? (dividir dicho monto por la cantidad de personas protegidas de forma tal de obtener información per cápita) 1.4. ¿Cuál es la inversión calculada en dólares destinada a líneas telefónicas de emergencia? (dividir dicho monto por la cantidad de llamadas recibidas de forma tal de obtener información por llamada) 1.5. ¿Cuál es la inversión calculada en dólares destinada a refugios? (dividir dicho monto por la cantidad de personas albergadas de forma tal de obtener información per cápita) 1.6. ¿Cuál es la inversión anual en dólares destinada a los programas de rehabilitación de víctimas? (dividir dicho monto por la cantidad de participantes en los programas de forma tal de obtener información per cápita) 1.7. ¿Cuál es la inversión anual en dólares destinada a solventar la investigación y recopilación estadística respecto de la violencia contra la mujer?”.

Ninguna de estas preguntas fueron contestadas. Algo muy grave que denota muy claramente el incumplimiento de las obligaciones de Argentina que emanan de los Tratados Internacionales de Derechos Humanos que protegen a la mujer.

De dicho informe podemos concluir lo siguiente: 1) existe reticencia a responder preguntas de contenido grave que puedan señalar la responsabilidad del Estado Argentino ante la inoperancia de las normas internacionales de protección a la mujer; 2) No existe sanción para los/las funcionarios/as públicos que no cumplen con la aplicación de las leyes de violencia; 3) tampoco hay una disposición obligatoria para que funcionarios públicos se capaciten en el tema; 4) a la fecha no existen informaciones estadísticas sobre las funciones del Programa Nacional del CNM; 5) no existen trámites expeditos y normados que garanticen efectivamente la aplicación de las garantías constitucionales en el tema en estudio; 6) sobre la violencia familiar, vimos que asume Argentina que existen demoras considerables en la resolución de los casos elevados a la justicia, lo que provoca injusticia; 7) no hay procesos contra funcionarios que incumplen el deber de recibir denuncias y tampoco obligación de capacitarse para mejor cumplir con su trabajo de atender a víctimas; 8) no cuenta con el material humano 
necesario para poner en funcionamiento las políticas públicas nacionales; 9) sobre los fondos, no hay partidas especiales para los programas que atañen al acoso sexual.

Asimismo no funciona aún en el Consejo Nacional de la Mujer el Programa de Información y Monitoreo de la Violencia Familiar contra la Mujer, destinado a producir información sistemática y confiable sobre la demanda de casos atendidos por Servicios en distintas regiones del país.

V) “Observaciones de la CEDAW 2010: Observaciones finales del Comité para la Eliminación de la Discriminación contra la Mujer Argentina.

1. El Comité examinó el sexto informe periódico de la Argentina (CEDAW/C/ARG/6) en sus sesiones $926^{\mathrm{a}}$ y $927^{\mathrm{a}}$, celebradas el 13 de julio de 2010. La lista de cuestiones y preguntas figura en el documento $\mathrm{CEDAW} / \mathrm{C} / \mathrm{ARG} / \mathrm{Q} / 6$, y las respuestas de la Argentina en el documento CEDAW/C/ARG/Q/6/Add.1.

...3. El Comité expresa también su agradecimiento al Estado parte por el diálogo constructivo mantenido y los esfuerzos realizados por la delegación, encabezada por el Representante Permanente de la Argentina ante las Naciones Unidas e integrada también por la Presidenta del Consejo Nacional de las Mujeres, para responder a las preguntas planteadas por el Comité. No obstante, observa que la delegación no ofreció respuestas sucintas, claras y directas en relación con algunos de los temas que se examinaban y dejó sin respuesta algunas de las preguntas formuladas por el Comité durante el diálogo, en particular con respecto a la primera parte de la Convención.

...9. El Comité recuerda la obligación del Estado parte de aplicar de manera sistemática y continua todas las disposiciones de la Convención sobre la eliminación de todas las formas de discriminación contra la mujer y considera que las preocupaciones y recomendaciones que se señalan en las presentes observaciones finales requieren la atención prioritaria del Estado parte desde el momento actual hasta la presentación del próximo informe periódico. En consecuencia, el Comité exhorta al Estado parte a que centre en esas esferas sus actividades de aplicación y a que, en su próximo informe periódico, indique las medidas adoptadas y los resultados conseguidos. El Comité exhorta al Estado parte a que transmita las presentes observaciones finales a todos los ministerios pertinentes, al parlamento y a las autoridades judiciales, a fin de que se pongan en práctica íntegramente. 
Parlamento:

10. Al tiempo que reafirma que incumbe al Gobierno la responsabilidad primordial de cumplir plenamente las obligaciones que el Estado parte ha contraído en virtud de la Convención y especialmente de rendir cuentas al respecto, el Comité destaca que la Convención es vinculante para todos los poderes públicos e invita al Estado parte a alentar a su parlamento a que, de conformidad con su reglamento y cuando proceda, adopte las medidas necesarias para dar aplicación a las presentes observaciones finales y al proceso relacionado con el próximo informe que debe presentar el Gobierno con arreglo a la Convención.

Responsabilidad del Gobierno federal:

11. Si bien el Comité es consciente de la complejidad de las estructuras constitucionales federales del Estado parte, subraya que incumbe al Gobierno federal la responsabilidad de velar por que se aplique la Convención y ofrecer su liderazgo a los gobiernos provinciales y territoriales en ese contexto. Preocupa al Comité el hecho de que el Gobierno federal carezca de un mecanismo eficaz que garantice la coherencia y la uniformidad de las medidas jurídicas y de otra índole que adopten los gobiernos provinciales para aplicar íntegramente la Convención.

12. El Comité, teniendo en cuenta la responsabilidad que incumbe al Gobierno federal en la aplicación de la Convención, insta al Estado parte a establecer un mecanismo eficaz que asegure la rendición de cuentas y la aplicación transparente, coherente y sistemática de la Convención en todo el territorio, con la participación de las autoridades nacionales, provinciales y territoriales.

Situación de la Convención en el ordenamiento jurídico interno y visibilidad:

13. Si bien encomia al Estado parte por otorgar rango constitucional a la Convención sobre la eliminación de todas las formas de discriminación contra la mujer y otros instrumentos internacionales de derechos humanos en su ordenamiento jurídico interno, el Comité observa que su aplicación efectiva sigue siendo limitada, al igual que la concienciación general sobre sus disposiciones y la adopción de medidas legislativas y de otra índole que prohíban la discriminación contra la mujer en todas sus formas. Preocupa al Comité el desconocimiento generalizado de la Convención y su Protocolo Facultativo en la Argentina, en particular entre las autoridades judiciales y otros funcionarios encargados de hacer cumplir la ley. Resulta especialmente preocupante que las propias mujeres no conozcan sus derechos con arreglo a la Convención ni el procedimiento de presentación de denuncias con arreglo al Protocolo Facultativo y, por 


\section{[LA PROTECCIÓN INTERNACIONAL DE LOS DERECHOS HUMANOS: CASO DEL ACOSO SEXUAL LABORAL EN

consiguiente, carezcan de capacidad para reivindicar la promoción, la protección y el cumplimiento plenos de sus derechos en pie de igualdad con los hombres.

14. El Comité insta a los Estados parte a adoptar medidas legislativas y de otra índole, con las sanciones correspondientes, que prohíban toda forma de discriminación contra la mujer y promuevan la igualdad, así como a aplicar medidas para difundir la Convención, su Protocolo Facultativo y las recomendaciones generales del Comité entre todos los interesados, incluidos ministerios gubernamentales, parlamentarios, autoridades judiciales y funcionarios encargados de hacer cumplir la ley, para que tengan conocimiento de ellos y cobren conciencia de los derechos humanos de la mujer. El Comité insta también al Estado parte a organizar campañas de concienciación dirigidas a las mujeres a fin de que tomen conciencia de sus derechos humanos y asegurar que disponen de procedimientos y recursos en caso de que se violen los derechos que les asisten con arreglo a la Convención.

Acceso a la justicia y mecanismos para presentar demandas judiciales:

15. Preocupa al Comité el hecho de que, aunque la legislación prevé el acceso de las mujeres a la justicia, su capacidad efectiva de ejercer ese derecho y llevar a los tribunales casos de discriminación está limitada por factores como la falta de información sobre sus derechos, barreras idiomáticas, especialmente en el caso de las mujeres indígenas, y otras dificultades estructurales para acceder a los tribunales. También preocupan al Comité los estereotipos de género imperantes en el sistema de justicia y su desconocimiento de la discriminación por motivos de sexo y de género, así como de la violencia contra la mujer.

16. El Comité pide al Estado parte que adopte todas las medidas necesarias para eliminar los impedimentos que pueden encontrar las mujeres para acceder a la justicia y que implante medidas encaminadas a garantizarles el acceso a la justicia. En concreto, recomienda que el Estado parte promueva la concienciación de la mujer respecto de sus derechos, en particular en las zonas rurales y entre los grupos más desfavorecidos, incluidas las comunidades indígenas, mediante programas de alfabetización jurídica y prestación de asistencia letrada con el objeto de que conozcan los recursos jurídicos de que disponen para luchar contra la discriminación y los abusos y hacer valer todos los derechos que les corresponden con arreglo a la Convención. Asimismo, insta al Estado parte a que vele por que la judicatura, incluidos jueces, abogados, fiscales y defensores 
públicos, conozcan los derechos de la mujer y las obligaciones del Estado parte con arreglo a la Convención, y alienta a este a que imparta capacitación sobre cuestiones de género a todos los miembros del sistema de justicia, entre ellos los organismos encargados de hacer cumplir la ley, y a que vigile los resultados de esa labor.

Mecanismos nacionales e incorporación de una perspectiva de género en las políticas y los programas nacionales:

17. Aunque acoge con satisfacción las actividades del Estado parte, preocupa al Comité el hecho de que, a pesar del reciente incremento del volumen de recursos financieros y humanos destinados al Consejo Nacional de las Mujeres, este sigue sin terminar de superar las deficiencias estructurales de que adolece desde su creación en 1992. En ese sentido, no parece que los mecanismos nacionales estén plenamente capacitados para promover de forma eficaz el adelanto de la mujer y la igualdad entre los géneros ni para preparar y aplicar políticas públicas en la totalidad del país. La aplicación de la Convención presenta grandes discrepancias entre las distintas provincias y municipios, mientras que todavía no se han eliminado determinados obstáculos sociales.

18. El Comité recomienda que el Estado parte siga fortaleciendo los actuales mecanismos nacionales subsanando los déficits estructurales que impiden su funcionamiento eficaz y aportando suficientes recursos financieros y humanos para aumentar su eficacia, su visibilidad y su capacidad de influir en la formulación, la concepción y la aplicación de políticas públicas y para reforzar sus funciones de coordinación en los planos nacional, provincial y municipal. Insta también al Estado parte a que siga invirtiendo en la elaboración de un sistema integral con indicadores de género a fin de mejorar la reunión de datos desglosados por sexo como método para evaluar la repercusión y la eficacia de las políticas y programas encaminados a incorporar la perspectiva de género y mejorar el disfrute por las mujeres de sus derechos humanos. El Comité destaca igualmente la necesidad de un plan de acción integral de lucha contra los obstáculos, estereotipos y errores sociales a fin de modificar las actitudes y dar cumplimiento efectivo a la ley.

19. Si bien acoge con beneplácito la ejecución de varios programas de transferencia de ingresos encaminados a reducir la pobreza y hacer frente al problema de la escasez de vivienda, incluida la concesión de asignaciones familiares mediante el sistema de Asignación Universal por Hijo para Protección Social, el Comité observa que no se ha incorporado plenamente una perspectiva de género en el diseño y la aplicación de estas políticas. 
20. El Comité recomienda que el Estado parte asegure la incorporación de perspectivas de género en todos los programas y políticas.

Medidas especiales de carácter temporal:

21. Si bien toma nota de la existencia de medidas especiales de carácter temporal en la legislación nacional del Estado parte, en particular en conexión con los sectores político y sindical, el Comité observa la limitada aplicabilidad de estas medidas en otros ámbitos en lo que a su conceptualización y aplicación se refiere.

22. El Comité insta al Estado parte a promover un debate amplio en relación con el artículo 4, párrafo 1, de la Convención y la recomendación general 25 del Comité, y a estipular medidas especiales de carácter temporal en todos los ámbitos, en particular en el ámbito civil, político, económico, social y cultural, con miras a lograr la igualdad efectiva entre los géneros, sobre todo para las mujeres que sufren múltiples formas de discriminación.

Violencia contra la mujer:

23. Al tiempo que acoge con beneplácito la Ley Integral para Prevenir, Sancionar y Erradicar la Violencia contra las Mujeres en los ámbitos que desarrollen sus Relaciones Interpersonales (Ley 26.485 de 2009), preocupa al Comité el hecho de que, transcurrido un año desde su adopción, no se haya aprobado legislación de aplicación ni se hayan asignado recursos financieros suficientes para la aplicación de la Ley.

24. El Comité insta al Estado parte a que acelere en todas las provincias la aprobación y aplicación coherentes de la legislación y el aporte de los recursos financieros necesarios para que entre plenamente en vigor la Ley Integral para Prevenir, Sancionar y Erradicar la Violencia contra las Mujeres en los ámbitos que desarrollen sus Relaciones Interpersonales. Para ello, a escala nacional, provincial y municipal debe procederse a la aplicación efectiva de la legislación vigente para hacer frente a todas las formas de violencia contra la mujer, como la violencia doméstica. El Comité alienta al Estado parte a fortalecer su sistema de reunión de datos relativos a todas las formas de violencia contra la mujer y a incorporar esos datos de conformidad con el procedimiento de seguimiento al que se hace referencia en el párrafo 51 de estas observaciones finales. En lo que respecta a la violación en el matrimonio, el Comité insta al Estado parte a que implante un sistema que aliente a las mujeres a denunciar los incidentes de ese tipo y a 
que establezca un conjunto de indicadores para evaluar las tendencias por lo que se refiere a la presentación de denuncias de este delito y su incidencia.

25. El Comité encomia el empeño del Estado parte por enjuiciar a los autores de los crímenes de lesa humanidad cometidos durante la pasada dictadura, pero lamenta que no se hayan impuesto penas a los autores de delitos de violencia contra mujeres perpetrados por aquella época en centros clandestinos de detención.

26. El Comité recomienda que se adopten medidas proactivas para hacer públicos, enjuiciar y castigar los incidentes de violencia sexual perpetrados durante la pasada dictadura, en el marco de los juicios por crímenes de lesa humanidad, de conformidad con lo dispuesto en la resolución 1820 (2008) del Consejo de Seguridad, y que se concedan reparaciones a las víctimas.

Empleo:

35. El Comité acoge con beneplácito las medidas adoptadas para reducir la tasa de desempleo de las mujeres, así como la función de la Comisión Tripartita de Igualdad de Oportunidades entre varones y mujeres en el ámbito laboral. El Comité expresa preocupación por las desigualdades en las condiciones de trabajo para las mujeres en los sectores estructurado y no estructurado de la economía, por la persistencia de la segregación ocupacional y la concentración de las mujeres en empleos poco remunerados, por las disparidades salariales entre mujeres y hombres en los sectores público y privado, por la falta de servicios de guardería y por la ausencia de legislación relativa al acoso sexual en el lugar de trabajo. A pesar de que se han adoptado algunas medidas para proteger a los empleados domésticos, el Comité observa con preocupación que su situación sigue siendo precaria.

36. El Comité insta al Estado parte a que adopte todas las medidas necesarias para garantizar una mejor aplicación de su legislación laboral, poner remedio a las desigualdades salariales, alentar a la mujer a buscar empleo en disciplinas no tradicionales, promulgar legislación relativa al acoso sexual en los lugares de trabajo públicos y privados, incluidas sanciones eficaces, y proporcionar protección integral a los empleados domésticos.

Declaración y Plataforma de Acción de Beijing:

47. El Comité insta al Estado parte a que, en el cumplimiento de las obligaciones contraídas en virtud de la Convención, aplique plenamente la Declaración y la Plataforma de Acción de Beijing, que refuerzan las disposiciones de la Convención, y le pide que incluya información al respecto en su próximo informe periódico. 
Objetivos de Desarrollo del Milenio:

48. El Comité hace hincapié en que para alcanzar los Objetivos de Desarrollo del Milenio es indispensable la aplicación plena y efectiva de la Convención. El Comité exhorta al Estado parte a que incorpore una perspectiva de género y se remita de forma explícita a las disposiciones de la Convención en todas las actividades destinadas a alcanzar dichos Objetivos, y le pide que incluya información al respecto en su próximo informe periódico.

Difusión:

49. El Comité pide que se dé amplia difusión en la Argentina a las presentes observaciones finales.

Ratificación de otros tratados:

50. El Comité señala que la adhesión del Estado parte a los nueve principales instrumentos internacionales de derechos humanos potencia que la mujer disfrute de sus derechos humanos y libertades fundamentales en todos los aspectos de la vida. El Comité acoge con beneplácito que el Estado parte haya ratificado la Convención Internacional sobre la protección de los derechos de todos los trabajadores migratorios y de sus familiares.

Seguimiento de las observaciones finales:

51. El Comité pide al Estado parte que le proporcione por escrito, en un plazo de dos años, información sobre las medidas adoptadas para dar cumplimiento a las recomendaciones que figuran en los párrafos 24 y 38 supra.

Preparación del próximo informe:

52. El Comité pide al Estado parte que vele por la amplia participación de todos los ministerios y órganos públicos en la preparación de su próximo informe y que, durante esa fase, consulte a diversas organizaciones de mujeres y de derechos humanos.

53. El Comité pide al Estado parte que responda a las preocupaciones expresadas en las presentes observaciones finales en el próximo informe periódico que prepare con arreglo al artículo 18 de la Convención. El Comité invita al Estado parte a que presente su próximo informe periódico en Julio de 2014".

Del presente informe reciente que constituye una crítica a la actuación del Estado Argentino, recogemos los puntos más sobresalientes a tener en cuenta para comprobar nuestra hipótesis, que refuerza lo dicho incluso en otros párrafos 
precedentes, sobre que el país finalmente será considerado infractor de los derechos humanos de las mujeres: 1) no emite respuestas a las preguntas formuladas; 2) solicita que se informe a las instituciones de gobierno sobre las recomendaciones; 3) la Convención es vinculante para todos los poderes públicos; 4) reafirma la responsabilidad del Estado; 5) la aplicación efectiva en Argentina de la Convención es limitada; 6) hace falta más concientización en la mujer; 7) como asimismo más medidas legislativas; 8) es muy grave el desconocimiento que tienen las autoridades judiciales, los encargados de aplicar la ley e incluso las propias mujeres de sus derechos para defenderse; 9) preocupa también la falta de campañas, de la existencia de estereotipos dentro del sistema judicial que no reconoce la discriminación o la violencia contra la mujer; 10) habla también de la capacitación al personal y es preocupante que no hay preparación para la tarea de promoción y de realización de las políticas públicas; 11) sostiene que se debe contar con un sistema integral de indicadores de género; 12) sorprende que a un año de la sanción de la ley 26.485, no haya presupuesto para su implementación, que no haya tampoco aplicación efectiva de las leyes vigentes; 13) sobre el acoso sexual, preocupa que no exista legislación laboral nacional ni provincial ni territorial; 14) solicita se informe sobre el cumplimiento de todas estas recomendaciones.

VI) “Argentina - Examen Periódico Universal (EPU) Consejo de Derechos Humanos - Primera sesión de EPU - 7/ 18 de abril de 2008-ELA - Equipo Latinoamericano de Justicia y Genero ("ELA") es una asociación civil sin fines de lucro constituida de conformidad con las leyes de Argentina, con el objetivo de promover la equidad de género y la plena vigencia de los derechos de las mujeres a través del derecho y las políticas públicas. Haremos referencia a aquellas áreas de mayor preocupación para nuestra organización.

A. Metodología y proceso de consulta seguido para la preparación del informe. A noventa días de la fecha en que el estado Argentino debe presentar su informe ante el Consejo de Derechos Humanos, no tenemos conocimiento de la existencia de un amplio proceso de consulta a las organizaciones de la sociedad civil. La pagina web del Ministerio de Relaciones Exteriores y Culto de la Nación no incluye información sobre la existencia del proceso de evaluación del EPU ni sobre las acciones tomadas al respecto. 
Legislación: En materia legislativa, se han aprobado numerosas normas vinculadas con el reconocimiento de los derechos humanos de las mujeres, tanto a nivel nacional como provincial. No nos detendremos aquí en su enumeración ya que la mayor dificultad que enfrenta la Argentina es la brecha existente entre el derecho formal y el derecho en la acción, que se evidencia en la escasa utilización de los procedimientos y normas legales disponibles, entre otros.

Organismos de Adelanto de la Mujer: El Consejo Nacional de la Mujer ("CNM") es en nuestro país el organismo gubernamental nacional responsable de las políticas públicas de igualdad de oportunidades y trato entre varones y mujeres. En su informe del año 2004 el Comité de la CEDAW observó el limitado papel que tiene el CNM en la estructura gubernamental ya que no forma parte del Gabinete de Ministros. A partir del año 2002, al magro presupuesto del CNM se sumó su desjerarquización institucional, ya que pasó a depender del Consejo Nacional de Coordinación de Políticas Sociales, bajo la presidencia del Ministerio de Desarrollo Social.

C. Promoción y protección efectiva de los derechos humanos: implementación de las obligaciones de derechos humanos. En Argentina, el problema no radica en el reconocimiento formal de derechos sino en asegurar su ejercicio. La retórica de la ley parece haber reemplazado el rol de las políticas públicas, necesarias para implementar y sostener con una política de estado los programas que traduzcan en respuestas concretas los derechos reconocidos. Estadísticas claras, precisas, confiables, con información segregada por sexo, ampliamente difundidas y disponibles para la población, son elementos esenciales para el monitoreo y evaluación de impacto de las políticas y programas implementados. Sin embargo, en aspectos claves para monitorear la vigencia y respeto de los derechos de las mujeres tales estadísticas no existen, son inadecuadas o incompletas. A modo de ejemplo señalamos: (i) no hay estadísticas ni información de alcance nacional sobre violencia familiar ni sobre violencia sexual; y (ii) en materia de delitos de violencia sexual, la información preparada por el Ministerio Publico Fiscal no discrimina por sexo, de modo que no es posible conocer, por ejemplo, la cantidad de víctimas mujeres y varones en delitos de violencia sexual.

Acceso a la Justicia: El acceso a la justicia, entendido como el derecho a conocer los derechos y los medios para ejercerlos; llegar a los tribunales contando con la asistencia gratuita de un abogado; contar también con los medios para sostenerse a lo largo del 
proceso judicial y tener un sistema judicial independiente y eficaz que llegue a pronunciamientos justos en tiempos prudenciales, es un derecho y el Estado tiene la obligación de garantizarlo. En una sociedad polarizada entre los sectores más ricos y los más pobres, importantes grupos de la población quedan fuera del mercado. La brecha de ingresos entre el 10\% superior de la distribución y el 10\% inferior llegó a 30 veces en el primer trimestre de 2007 y mientras el 10\% superior en la escala de ingresos capta el $35 \%$ del PBI, el 10\% inferior, sólo el 1\%. Las clases medias empobrecidas se constituyeron en la nueva clientela de los servicios sociales, hasta entonces reservados para los más pobres, que perdieron toda capacidad para acceder a los mismos. Investigaciones realizadas en la ciudad de Buenos Aires señalan que la mitad de las mujeres de bajos recursos no sabe que existen servicios de asistencia jurídica gratuita; alrededor del $12 \%$ sabe que existen pero los desconocen y poco más del $30 \%$ puede nombrar alguna institución que los preste. El 51\% de las mujeres de menores recursos entrevistadas manifestó haber tenido por lo menos uno de seis problemas legales mencionados específicamente y sólo cuatro de cada diez manifestó haber contado con la asistencia de un abogado para su resolución. Manipulaciones sobre el Índice de Costo de Vida que elabora el Instituto Nacional de Estadísticas y Censos (INDEC) quitó credibilidad a la información que produce el Estado.

Violencia contra la mujer: Se desconoce la dimensión de la problemática de violencia familiar en el país dada la ausencia de información estadística nacional. En materia de violencia sexual, la falta de información empírica a nivel nacional, la inconsistencia entre los datos producidos por distintas reparticiones y la ausencia de información discriminada por sexo dificultan la elaboración de un diagnóstico que dé cuenta de la magnitud del problema de violencia sexual contra las mujeres. La creación de una Unidad Fiscal para la Investigación de Delitos contra la Integridad Sexual, Trata de Personas y Prostitución Infantil (UFI-INTEGRIDAD SEXUAL) en el año 2005 resulta auspiciosa, aunque a la fecha no cuenta todavía con información estadística que dé cuenta de los delitos sexuales que investiga.

ANEXO-Posibles recomendaciones para realizar-Argentina - Examen Periódico Universal (EPU) Consejo de Derechos Humanos - Primera sesión de EPU - 7 / 18 de abril de 2008.

Organismos de Adelanto de la Mujer: 1. Se recomienda que el Estado Nacional asigne al Consejo Nacional de la Mujer (CNM) un presupuesto acorde a las políticas que debe 
llevar adelante. 2. Se recomienda mejorar la coordinación entre el CNM y las oficinas provinciales y municipales de Adelanto de la mujer.

Acceso a la justicia: 1. Se recomienda la organización de un sistema coordinado de servicios jurídicos gratuitos disponibles en forma descentralizada para satisfacer las necesidades de la población, que integre las prestaciones y recursos disponibles de organismos públicos y privados. 2. Se recomiende la realización de una amplia campaña de difusión de derechos a la ciudadanía, con especial cuidado en utilizar un lenguaje claro y accesible. 3. Se recomienda el establecimiento de procedimientos claros, eficaces y transparentes para la realización de los derechos de los ciudadanos.

Violencia contra la mujer: 1.Se recomienda la realización de una encuesta de alcance nacional con el objetivo de conocer acabadamente la dimensión y características de la violencia contra las mujeres.

Derecho al trabajo y autonomía de las mujeres: 1. Se recomienda la difusión de servicios de cuidado en el marco de políticas de conciliación de la vida laboral y familiar que se piensan como políticas para los hogares y no para las mujeres, de modo de superar el rol de las mujeres como principales cuidadoras".

Conclusión: 1) Señala esta organización de derechos humanos, la marcada brecha existente entre el derecho formal (el escrito) y el derecho en la acción o real o de vigencia de la ley por su aplicación y eficacia, que constituye un gran problema para Argentina a la hora de asegurar su ejercicio; 2) Las políticas públicas son necesarias para implementar y sostener con una política de estado los programas que traduzcan en respuestas concretas los derechos reconocidos, pero que se hallan ausentes dada la realidad; 3) Pide se elaboren estadísticas claras, precisas, confiables, con información segregada por sexo, ampliamente difundidas y disponibles para la población; 4) Las anteriores, se consideran esenciales para el monitoreo y evaluación de impacto de las políticas y programas del gobierno; 5) Por último, algo muy grave es que destaca que para monitorear la vigencia y respeto de los derechos de las mujeres tales estadísticas no existen, son inadecuadas o incompletas.

VII) “Memoria de actividades realizadas - 2009-Introducción. En el año 2007, por Resolución MTEySS $\mathrm{N}^{\circ}$ 05/07, se creó en el ámbito del Ministerio de Trabajo, Empleo y Seguridad Social, la Oficina de Asesoramiento sobre Violencia Laboral 
(OAVL), con la finalidad de promover políticas públicas orientadas a la prevención, difusión de la problemática e intervención ante situaciones de violencia laboral, tanto en el ámbito público como privado, en todo el territorio nacional. La necesidad de abordar la problemática de la Violencia Laboral tuvo como antecedente el consenso alcanzado al respecto en el seno de la Comisión Tripartita de Igualdad de Trato y Oportunidades entre Varones y Mujeres en el Mundo Laboral (CTIO), que integran representantes del sector sindical, empresarial y gubernamental. Por otra parte, la creciente demanda de asistencia por parte de trabajadores/as ante el MTEySS, también fundamentó la conveniencia de instaurar un área específica con competencias ejecutivas y de gestión. La definición de Violencia Laboral adoptada por esta Oficina comprende "toda acción, omisión o comportamiento, destinado a provocar, directa o indirectamente, daño físico, psicológico o moral a un trabajador o trabajadora, sea como amenaza o acción consumada. La misma incluye violencia de género, acoso psicológico, moral y sexual en el trabajo, y puede provenir tanto de niveles jerárquicos superiores, del mismo rango o inferiores."

Las funciones asignadas a la OAVL comprenden: Atender consultas y/o recepcionar denuncias sobre violencia laboral, asesorando en aspectos legales y en lo referente a la salud psicofísica, garantizando confidencialidad en todas las etapas del procedimiento a que se diera lugar. En el caso de denuncias referidas al sector privado, la intervención de la Oficina se orienta a procurar el acercamiento de las partes, previo consentimiento del denunciante. Si la denuncia está referida al sector público se deriva el caso a la COMISIÓN DE IGUALDAD DE OPORTUNIDADES Y DE TRATO (CIOT) y, si corresponde, se remite copia de todas las actuaciones a la Fiscalía Nacional de Investigaciones Administrativas. En el caso de denuncias referidas al Sector Público Provincial se aplica el procedimiento correspondiente a cada Jurisdicción; contribuir a la conformación de una base conceptual, empírica, legislativa y documental, atendiendo perspectivas locales, nacionales e internacionales, con el propósito de fomentar el debate, divulgar la problemática y promover la adopción de medidas conducentes a su prevención y corrección en los ámbitos pertinentes; establecer vínculos de cooperación y asistencia con áreas internas del MINISTERIO, otros organismos públicos y privados, nacionales e internacionales que compartan objetivos similares o complementarios; desarrollar y promover tareas preventivas mediante la realización de actividades de sensibilización, difusión y capacitación sobre el tema hacia diferentes sectores que, en distintas formas, tengan intervención o sean alcanzados por esta temática. 


\section{ARTICULACIÓN INSTITUCIONAL: - INSTITUTO NACIONAL CONTRA LA}

DISCRIMINACIÓN LA XENOFOBIA Y EL RACISMO, en la atención y seguimiento de casos que involucran situaciones de violencia laboral y discriminación y articulación de acciones de investigación. - CONSEJO NACIONAL DE LA MUJER: participación en la subcomisión para la integración de un Registro Nacional de casos de violencia contra la mujer (establecido en la Ley N²6.485)".

Destacamos los objetivos de la OAVL pues daremos más adelante algunos datos que establece la misma desde su posición como integrante del gobierno.

VIII) “Argentina - Examen Periódico Universal (EPU) -Consejo de Derechos Humanos -Sesión $14^{\circ}$ de EPU - 22 octubre $/ 5$ noviembre 2012. Informe elaborado por ELAEquipo Latinoamericano de Justicia y Género.

A. Introducción

...2. A cuatro meses de que el Estado debe presentar su informe ante el Consejo, no tenemos conocimiento de la existencia de un amplio proceso de consulta a las organizaciones de la sociedad civil. Esto contraría el párrafo 17 de la resolución $\mathrm{A} / \mathrm{HRC} / \mathrm{RES} / 16 / 21$ que alienta a los Estados a realizar consultas con todas las partes pertinentes en el seguimiento del EPU. Este silencio estatal es sintomático de su resistencia a brindar información pública, tema que abordaremos en el presente Informe.

3. De acuerdo con nuestra área de trabajo, este Informe aborda principalmente los avances y deficiencias respecto de la obligación estatal de garantizar una vida libre de violencia para las mujeres y la obligación de no discriminación en el empleo en razón del sexo. Además, llamamos la atención sobre la falta de políticas públicas de articulación trabajo - familia y los efectos que esto tiene sobre la autonomía de las mujeres, y la desprotección legal y política de las trabajadoras del servicio doméstico.

Legislación:

5. ..Por esta brecha entre derechos formales y cumplimiento real, el Estado recibió diversos llamados de atención en el ámbito internacional de protección de derechos humanos.

Organismos de la Mujer:

6. El Consejo Nacional de las Mujeres (CNM) ...tiene a su cargo la implementación de la "Ley de protección integral para prevenir, sancionar y erradicar la violencia contra las mujeres en los ámbitos en que desarrollan sus relaciones interpersonales". Sin embargo, no 
cuenta con presupuesto asignado para llevarla adelante, la presidencia del CNM es elegida discrecionalmente por el Poder Ejecutivo, y es un órgano con muy escasa difusión de sus actividades y alcances.

Promoción, protección efectiva e implementación de las obligaciones de derechos humanos: I- Dificultades en el acceso a la información pública.

9. Las dificultades en el acceso a la información pública es un ítem por el que periódicamente Argentina es observada en los foros internacionales. El Instituto Nacional de Estadísticas y Censos (INDEC) ha sido intervenido en el año 2007 por el gobierno nacional, y sus estadísticas perdieron absoluta credibilidad. Las denuncias de manipulación de datos son constantes. Argentina tampoco cuenta con una ley nacional de acceso a la información pública, únicamente con leyes y decretos provinciales y un decreto del Poder Ejecutivo que rige exclusivamente para el Ejecutivo nacional. Los pedidos de información al Ejecutivo nacional, aun cuando cumplan con el decreto, son sistemáticamente rechazados. Otro motivo de atención en foros internacionales ha sido la escasa información desagregada por sexo con la que cuenta el Estado, situación que continúa inalterable.

II - Violencia contra las mujeres:

10. En relación a la temática de la violencia contra las mujeres, los tres principales déficits que identificamos son: la ausencia de estadísticas que permitan dimensionar el alcance y modalidades bajo las cuales se manifiesta, las dificultades para el acceso a la justicia que deben enfrentar las víctimas y la falta de políticas públicas integrales para afrontarla.

Ausencia de estadísticas:

11. Contar con estadísticas claras, precisas, confiables, con información segregada por sexo, ampliamente difundidas y disponibles para la población acerca del alcance y tipos de violencia es esencial para el diseño y monitoreo de las políticas y programas específicos. Sin embargo, tales estadísticas no existen, o son inadecuadas o incompletas. A modo de ejemplo señalamos que, al igual que en el informe presentado para la primera ronda del EPU, continuamos sin tener: a) encuestas representativas de la población nacional para conocer la incidencia y prevalencia de las distintas manifestaciones de violencia, b) estadísticas ni información de alcance nacional sobre denuncias formuladas y servicios de atención brindados a víctimas de violencia intrafamiliar o sobre violencia sexual; y c) en materia de delitos de violencia sexual, la información preparada por el Ministerio Público Fiscal no discrimina por sexo, de modo que no es posible conocer, por ejemplo, la cantidad de víctimas mujeres y varones en estos delitos.

Dificultades para acceder a la justicia:

8. En consecuencia, sugerimos la siguiente recomendación: 
Los Estados manifiestan su preocupación por la falta de una autoridad nacional con suficiente legitimación, jerarquía institucional, recursos económicos y humanos que centralice y articule como una política integral las diversas iniciativas existentes en materia de violencia contra las mujeres, tanto a nivel nacional como en las jurisdicciones provinciales.

12. El acceso a la justicia, entendido como el derecho a conocer los derechos y a ejercerlos efectivamente, requiere para su concreción poder llegar a los tribunales contando con la asistencia jurídica gratuita; contar con medios para sostenerse a lo largo del proceso y tener un sistema judicial independiente y eficaz que llegue a pronunciamientos justos en tiempos prudenciales. Al ser un derecho, el Estado tiene obligación de garantizarlo. Los obstáculos para su ejercicio incluyen barreras geográficas y edilicias (ya que los tribunales no se encuentran acondicionados para garantizar la privacidad de las víctimas, ni están adaptados a personas con discapacidad y/o transportes de bebés). Los servicios de patrocinio jurídico gratuito son escasos, y no se especializan en violencia.

Falta de políticas públicas:

13. Argentina es un Estado federal, lo cual hace que se superpongan diversas leyes, organismos y funciones entre los estados nacional y provinciales. No obstante, la falta de coordinación no excusa al Estado para incumplir obligaciones internacionales. La dispersión de iniciativas aisladas, de alcance acotado, superpuestas, no hace más que dilapidar recursos y atentar contra el buen funcionamiento institucional. Erradicar la violencia contra las mujeres requiere múltiples abordajes: jurídico, sanitario, social, educativo. Sin embargo, hay muchas dependencias públicas dispersas con programas de atención acotados, que arrastran a las víctimas a un derrotero burocrático desgastante e infructuoso. La creación de un programa integral a nivel nacional de prevención y erradicación de la violencia se vuelve imperiosa, así como un seguimiento estadístico serio del alcance de la violencia.

14. Sugerimos lo siguiente:

Preocupa a los Estados la falta de información respecto de la violencia contra las mujeres en sus distintas manifestaciones: violencia doméstica, violencia sexual, asesinatos. Se recomienda la implementación de mecanismos efectivos de recopilación de información segregada por sexo tanto a nivel administrativo como judicial y de alcance nacional, elaborada de un modo sistemático, consistente y comparable entre jurisdicciones. Se insta al Estado a que, a partir de la información recopilada, diseñe, implemente y monitoree políticas públicas integrales de acceso a la justicia para las 
víctimas de violencia en sus distintas manifestaciones. Estas deberán incluir, entre otras prestaciones, servicios gratuitos especializados y extendidos de patrocinio legal y atención psicológica, refugios y facilidades para acceder a subsidios".

Conclusión: 1) Nuevamente señala la organización la falta de consulta a las ONGs de la Sociedad Civil por parte del Estado para producir los informes sobre la Convención; 2) Señalan además la resistencia a que el Estado brinde información pública; 3) La falta de políticas públicas con respecto a la mujer en el trabajo y en la familia; 4) Sigue la brecha entre el derecho formal y la realidad por el cual se hicieron múltiples llamados de atención a Argentina; 5) Desconoce al CNM por su falta de legitimación, jerarquía institucional, recursos económicos y humanos; preocupa que no tenga presupuesto propio y que al presidente del CNM lo elija el Poder Ejecutivo; también que no tenga difusión de sus funciones en la sociedad. Aunque falta detallar más recomendaciones, todas son exactamente iguales a las que ya diera en anterior informe del año 2008, y por ende, significa que no se solucionaron ninguna de las fallas del Estado Argentino en el período 2008-2012.

IX) "Informe Alternativo para el Comité de Derechos Económicos, Sociales y Culturales $46^{\circ}$ PERÍODO DE SESIONES / EVALUACIÓN SOBRE ARGENTINA. Estimadas expertas y estimados expertos del Comité: Las organizaciones firmantes, dedicadas a la defensa y protección de los derechos humanos en Argentina nos dirigimos a Uds. con relación al tercer informe periódico presentado por Argentina sobre la vigencia del Pacto Internacional de Derechos Económicos, Sociales y Culturales. En ese sentido, a continuación, ponemos a su disposición el listado de preguntas que, entendemos, debería transmitirse al Estado al examinar el informe oficial... Asociación por los Derechos Civiles (ADC), Centro de Derechos Humanos de la Universidad Nacional de Lanús (CDHUNLa), Centro de Estudios Legales y Sociales (CELS), Equipo Latinoamericano de Justicia y Género (ELA), Foro Ciudadano de Participación por la Justicia y los Derechos Humanos (FOCO), Fundación Ambiente y Recursos Naturales (FARN), Fundación InterAmericana del Corazón Argentina, Fundación para el Desarrollo de Políticas Sustentables (FUNDEPS), Fundación Sur Argentina, Grupo 14 bis, Observatorio del Derecho Social de la Central de Trabajadores Argentinos (CTA). PREGUNTAS SUGERIDAS AL ESTADO ARGENTINO...”.

En este informe, se dan recomendaciones para efectuar preguntas a Argentina, sobre los problemas relacionados con el acceso a la información para analizar la 
situación en el país sujeto a exámen. Ello provoca la imposibilidad de contar con un diagnóstico preciso sobre los niveles concretos de cumplimiento de las obligaciones que emanan de la Convención. En la actualidad, no existen en el país estadísticas oficiales confiables en temas tan sensibles como empleo, pobreza e inflación. Esto ha implicado la proliferación de mediciones alternativas que revelan, entre otras cosas, que los niveles de inflación, pobreza e indigencia son muy superiores a aquellos sostenidos por las estadísticas oficiales (COMITÉ DE DERECHOS HUMANOS, ONU, Lista de cuestiones que deben abordarse al examinar el cuarto informe periódico de Argentina, $97^{\circ}$ período de sesiones, 22 de agosto de 2009, CCPR/C/ARG/Q/4).

Es necesario contar con información fidedigna para analizar los diferentes aspectos relacionados con el diseño, la implementación y el impacto de las políticas sociales asociadas con temas relacionados con el mercado laboral, salarios, pobreza, indigencia, entre otros. Y de allí poder esquematizar científicamente los datos relativos al acoso sexual laboral, que no hemos podido formular debido a la insuficiencia y carencia absoluta de dichos informes por parte del gobierno argentino, que incluso muestra silencio ante los interrogantes de los organismos internacionales al ser abordado por este tema -como se vio antes con los distintos informes transcriptos-. Siendo el responsable directo el Estado sobre quien pesa dicha obligación de informar, solo se saben los datos limitados que emiten las ONGs particulares como ELA.

X) Así, en el año 2012, con motivo del XX Congreso Mundial de Derecho del Trabajo y de la Seguridad Social, celebrado en Chile en el mes de septiembre, Argentina contestó una serie de preguntas relativas a la legislación de protección contra la violencia laboral y en especial sobre el acoso sexual que señalamos textual:

"En la Argentina no se ha legislado específicamente en materia de acoso sexual. Básicamente los mecanismos de prevención se han implementado a través de programas de concientización y divulgación. Sólo en el ámbito público se han establecido mecanismos específicos de inspección, consulta, información y denuncia tanto a través de convenios colectivos regidos por la ley de negociación colectiva en el sector público -a nivel nacional- como mediante el dictado de leyes a nivel local. En el ámbito público la tarea preventiva e investigativa desarrollada por las entidades gremiales ha resultado de gran significación". 
"Desde hace ya casi 10 años en el Congreso de la Nación se presentan continuamente proyectos legislativos para regular los distintos supuestos de violencia laboral entre los que se encuentra, obviamente, el acoso sexual. En todos los proyectos compulsados se prevén mecanismos específicos de prevención”. Con respecto a esto, logramos comprobar que no se aprueban.

"En el sistema jurídico argentino no existe sanción penal para el acoso sexual." "Dentro del magro y cuestionado esquema de la Ley de Riesgos del Trabajo (ley 24.557 y sus reglamentaciones) no está previsto el acoso sexual como un riesgo laboral (enfermedad profesional o accidente de trabajo)".

“Con relación al acoso sexual, la ley no prevé en forma concreta obligación alguna de manera diferenciada (para el empleador)".

La mayoría de las leyes sobre igualdad de oportunidades establecen los siguientes procedimientos: una persona presenta una denuncia por escrito; los funcionarios del órgano especializado realizan una investigación; si consideran que el caso está motivado, los funcionarios convocan a las partes a una reunión de conciliación; si ésta fracasa, el asunto se remite a un consejo del órgano especializado o a otro órgano, por ejemplo un tribunal. Debido a la relativa sencillez y rapidez de ese procedimiento, algunos autores son partidarios de seguir el camino de la legislación sobre igualdad de oportunidades. Cuando se recurre al derecho laboral, suele observarse que los servicios de inspección del trabajo (que son los primeros que intervienen para conocer las denuncias o descubrir delitos de índole sexual en el trabajo) carecen de la capacidad técnica necesaria para examinar de forma imparcial y experta los casos de hostigamiento sexual (véase, por ejemplo, Serna Calvo, 1994). En todas las jurisdicciones, los pleitos son en general caros, duran mucho tiempo y sus resultados son inciertos.

XI) Informe del año 2015 de la CIDH de la OEA sobre "Acceso a la información, violencia contra las mujeres y la administración de justicia en las Américas". El informe procura ofrecer una primera aproximación a los desafíos que enfrentan las mujeres en las Américas para tener un acceso adecuado a la información controlada por el Estado en materia de violencia y discriminación. Asimismo, busca sistematizar los estándares internacionales que se han desarrollado en el Sistema Interamericano sobre esta materia e identificar las buenas prácticas en la región respecto de la aplicación y cumplimiento de dichos estándares. 
La CIDH ha observado que aún en aquellos Estados que cuentan con mecanismos institucionalizados para la recopilación, procesamiento y producción de información sobre violencia contra las mujeres, muchas veces la difusión de dicha información resulta insuficiente. Del mismo modo, la $\mathrm{CIDH}$ ha notado que en la región existe una falta de coordinación generalizada entre los diversos sistemas de recopilación y producción de información que coexisten en los Estados, por ejemplo, los registros de las oficinas de asistencia jurídica gratuita, los datos recopilados por los observatorios de violencia o discriminación y los mecanismos de estadísticas judiciales.

En relación con los principales desafíos en materia del acceso a la información pública sobre discriminación y violencia, la $\mathrm{CIDH}$ ha constatado en diversas oportunidades la existencia de deficiencias en la disponibilidad, calidad e integridad de la información pública sobre violencia y discriminación contra las mujeres, tales como la falta de recopilación de información completa sobre todas las formas de violencia y discriminación en los diversos órganos del Estado, la falta de producción de estadísticas integrales a partir de esa información y la desagregación de la información estadística según factores como el sexo, raza, etnia, edad, condición social, orientación sexual, identidad de género y discapacidad, y otros criterios que permitan apreciar la incidencia real de la violencia y la discriminación en grupos específicos de mujeres. La importancia de la recopilación de datos y la producción de estadísticas ha sido destacada en el Sistema Interamericano y en el Sistema de Naciones Unidas como el mecanismo fundamental para el diseño y evaluación de las políticas públicas y programas de prevención, atención y protección frente a la violencia y la discriminación.

Otro desafío prioritario en esta materia guarda relación con la implementación efectiva de los estándares internacionales sobre acceso a la información en el ámbito nacional. Al respecto, la CIDH ha constatado que si bien la gran mayoría de los países de la región cuentan con normativa constitucional y/o legal en tal sentido, no se cuenta con información concreta acerca de la implementación material de dicha normativa y su efectividad, de manera que es desafiante evaluar el nivel de cumplimiento de las obligaciones estatales en esta materia.

Por otra parte, el acceso a la información en el ámbito de la administración de justicia es un área de especial interés para la $\mathrm{CIDH}$, en la cual se presenta una serie de desafíos relacionados con la garantía del acceso a la información en su dimensión de 
derecho facilitador del acceso a la justicia para las mujeres víctimas de violencia y discriminación. En este contexto, la CIDH destaca como desafíos prioritarios el asegurar a las mujeres y sus familiares el acceso a la información sobre sus casos pendientes de violencia o discriminación, la disponibilidad de servicios adecuados y suficientes de asistencia jurídica gratuita y el acceso a intérpretes e información en lenguas diversas para las mujeres que no hablan en idioma oficial del Estado, entre otros.

La CIDH subraya la importancia de contar con información pública respecto del funcionamiento de la administración de justicia, incluyendo datos acerca del número de arrestos, procesamientos, condenas, órdenes de protección y sentencias dictadas; el tiempo de resolución de los casos; la composición de género de los sistemas de justicia; los presupuestos asignados a la actividad judicial; y los mecanismos internos de rendición de cuentas.

La Comisión insta a los Estados Miembros de la Organización de Estados Americanos (OEA) a adoptar medidas encaminadas a garantizar la disponibilidad de servicios de asistencia jurídica gratuita de calidad, la capacitación de los operadores de justicia y demás funcionarios públicos que actúen en materia de violencia, y la implementación de protocolos de actuación frente a casos de violencia inminente. Igualmente, reitera su disposición para colaborar con los Estados en sus esfuerzos en la esfera de protección fundamental para el ejercicio de los derechos de las mujeres.

Este informe fue elaborado por la Relatoría sobre los Derechos de las Mujeres con la asistencia técnica de la Relatoría Especial para la Libertad de Expresión de la CIDH. La Comisión agradece el apoyo de la Agencia de Cooperación para el Desarrollo Internacional de Suecia (ASDI-SIDA) para la ejecución de esta iniciativa”.

El informe ha relatado las fallas del Estado Argentino en aplicar las normas internacionales de protección contra la violencia a la mujer, entre ellas el acoso sexual laboral, y es síntesis de los distintos informes ya transcriptos y comentados ut supra, por lo que consideramos que nuestra hipótesis se encuentra fundada.

\section{7 RESPONSABILIDAD DEL ESTADO ARGENTINO}

\subsubsection{Fundamento}

Con la evaluación que hasta el momento podemos hacer sobre la situación del país respecto del cumplimiento o no de los Tratados Internacionales de Derechos Humanos, sobre todo en lo que hace a nuestro tema de investigación, necesitamos 
abordar el siguiente tema para considerar si ante tal o cual situación, merece responder por su acción, omisión, o negligencia ante la comunidad internacional.

Por ello, y haciendo un poco de historia, decimos que en 1953 la Comisión de Derecho Internacional de las Naciones Unidas emprendió el estudio del presente tema, la responsabilidad, pero existen complejidades en la misma cuestión como así también implicaciones políticas que obstruyen el camino hacia la efectiva aplicación de correcciones. En 1980 en una primera lectura, la Comisión aprobó la primera parte de un Proyecto de artículos sobre Responsabilidad que se limita a tratar el origen de la responsabilidad (o sea los elementos del acto ilícito internacional) de 35 artículos. La segunda parte del Proyecto trata sobre el "contenido, formas y grado de responsabilidad". Cuando se trata de construir un régimen de responsabilidad para todas las posibles violaciones del derecho internacional, aparecen dificultades bastante serias, tanto porque la práctica se hace sumamente fragmentaria e incierta, como porque en el caso de muchas y muy graves violaciones, hay que hablar de una obligación de justa reparación o por la escasez de medios para garantizar la puesta en práctica de las normas internacionales.

El acto ilícito internacional consiste en un comportamiento de uno o más órganos estatales (considerando al Estado como Estado-organización; Conforti, 1995, pág. 419). Sólo los órganos estatales con los cuales se identifica el Estado son autores posibles de violaciones al derecho internacional. Según el Proyecto, indica como elementos del acto ilícito, en su art. $3^{\circ}$ : a) un comportamiento (acción u omisión) atribuible al Estado y b) la ilicitud de ese comportamiento. El primer elemento (subjetivo) consiste en el "...comportamiento de cualquier órgano del Estado que tenga ese carácter en virtud del derecho interno de dicho Estado...". Desde el punto de vista del derecho internacional no hay importancia en individualizar qué órgano debió activarse y no lo hizo y sus competencias, ya que al Estado no sólo se le atribuirán las acciones ilícitas cometidas por los órganos del poder -legislativo, judicial o administrativo- central, sino también las cometidas por los órganos de los entes públicos territoriales o de otras personas a las cuales se atribuye potestad de gobierno, y las violaciones perpetradas por los privados cuando hayan asumido, de hecho, funciones públicas siempre que dicho ejercicio del poder de gobierno esté permitido o ratificado de hecho por el derecho interno. Y todo a pesar de que se haya extralimitado en sus 
competencias el órgano estatal. De lo que surge pues, la responsabilidad del Estado cuando no ha procedido a adoptar las medidas tendientes a prevenir la acción o a castigar al responsable y, por lo tanto, debe responder por las acciones de sus propios órganos (art. 11 de la Primera Parte del Proyecto).

El elemento objetivo del acto ilícito internacional, es decir, la violación de la norma internacional, la antijuridicidad, está definida por el art. 16 del Proyecto: “estamos ante una violación de una obligación internacional por parte de determinado Estado cuando un acto de ese Estado no se conforma a lo que le impone dicha obligación".

El deber de hacer cesar el ilícito y de eliminar sus efectos en la medida de lo posible -cese y eliminación que constituyen la llamada reparación in integrum- es un aspecto de esa obligación que se ha violado.

Al no aplicar los estándares internacionales sobre derechos humanos en materia de acoso sexual laboral en el país, Argentina se hace responsable así internacionalmente frente a toda la comunidad.

\subsubsection{Función de los Tribunales Internacionales:}

La función jurisdiccional internacional es de naturaleza voluntaria, ya que está ligada al principio según el cual un juez internacional aunque haya sido constituido como tal, nunca puede juzgar a menos que su jurisdicción haya sido previamente aceptada por todos los Estados que sean parte en una controversia. Con respecto a la Corte Internacional de Justicia sus opiniones si bien no son vinculantes en términos de la Carta de la ONU, pueden volverse obligatorias si los Estados se comprometen a respetarlas en un acuerdo o en cualquier otro acto vinculante. Serían así verdaderos compromisos arbitrales semejantes a aquellos en los que se funda la jurisdicción de la Corte en materia contenciosa. 


\section{Capítulo $\mathrm{V}^{\mathrm{o}}$ \\ PRODUCCIÓN JURISPRUDENCIAL}

\subsection{ARGENTINA}

Seguidamente y con el claro propósito de demostrar la hipótesis planteada, desarrollamos aquí el otro de los indicadores de nuestra variable independiente, como complemento -aunque por sí solo el argumento de los informes emitidos por la CEDAW, EPU y ELA, y hasta los informes emitidos por el gobierno, son de por sí suficiente prueba que demuestran por sí solas el planteo de la presente investigaciónpresentamos así las sentencias que siendo pocas, existen en la jurisdicción nacional sobre el reconocimiento del acoso sexual laboral. Sólo reproduciremos y señalaremos lo que hace a nuestro tema de estudio, pudiendo acudir el interesado a la fuente para su mayor información. Y ya estudiados los dos indicadores, sabremos cuál ha sido la voluntad política (intereses, intención) del éxito o fracaso de la aplicación o no del derecho internacional de los derechos humanos en materia de acoso sexual laboral en Argentina respecto del mundo.

También aclaramos que la primera denuncia penal por acoso sexual en Argentiina se hizo en el año 1999, en la ciudad de La Plata, cuando no existía la Ley provincial $\mathrm{n}^{\circ} 12.764$, terminó siendo sobreseído el acusado sin investigarse las pruebas en su contra, intervino como Juez de Garantías el Dr César Melazo (hoy ex juez, acusado entre otros delitos, de corrupción, enriquecimiento ilícito y de graves irregularidades en sus funciones). A la fecha actual, después de haber sido admitida la demanda contra el Estado Argentino, se debate en la Comisión Interamericana de Derechos Humanos de la OEA la cuestión de fondo, como el primer caso de acoso sexual laboral en el mundo a ser investigado por dicha Comisión.

A) Por ejemplo, la Sala I de la Cámara Civil y Comercial de Apelaciones de Lomas de Zamora hizo lugar a un reclamo de daños y perjuicios producidos como consecuencia del acoso sexual que sufrió una trabajadora por parte de un empleado jerárquico, condenando a este último y a la compañía empleadora al pago de una suma de dinero “....situación que implica un tema de discriminación en la comunidad laboral para el trabajador/a que no acepta el avance o asedio sexual y produzca cambios en las 
condiciones de trabajo, cesantía o cualquier otra forma de menoscabo en su condición de ser humano y trabajador, importando una restricción personal a la libertad de elegir" (aplicó el artículo 1071 bis del Código Civil, artículo 19 de la Constitución Nacional) (Cámara Civil y Comercial de Lomas de Zamora, Sala I, 19/11/2002, "M.L.B. c/ Isa, Juan y otro").

B) Sentencia Comentada (informe periodístico):

"Primera sentencia en Argentina por acoso sexual de una mujer a otra. Ordenan a la dueña de un instituto de belleza pagar 32.800 pesos más intereses a su ex empleada. Parte de ese monto corresponde al tratamiento por depresión que necesita la joven": La cosmetóloga, una inmigrante ucraniana de 27 años que llevaba 3 viviendo en la Argentina, entró a trabajar en el instituto de belleza de la calle Quintana, en Recoleta, en octubre de 1994. Muy pronto, la dueña del negocio empezó a acercarse a ella con regalos y hasta le ofreció comprarle un departamento que la empleada pagaría en cuotas, con una parte de su sueldo. Una noche la invitó a cenar a su departamento y la cosmetóloga fue recibida con luces tenues y champán. Cuando la jefa le dijo que quería tener relaciones sexuales con ella, la empleada se fue del departamento. Y al poco tiempo fue despedida del trabajo. Más de 8 años después, la cosmetóloga ucraniana acaba de ganarle un juicio a la dueña del negocio, en la que sería la primera sentencia de la Justicia argentina que otorga una indemnización por acoso sexual entre mujeres. El juez civil Francisco Granillo Ocampo condenó a la jefa a pagarle 32.800 pesos más intereses a la empleada. Esta cifra corresponde exclusivamente al acoso sexual y se suma a los 4.767 pesos como indemnización por despido que la cosmetóloga le había ganado a la dueña hace cuatro años ante la Justicia laboral. "Creemos que es el primer caso de acoso sexual entre mujeres admitido por la Justicia argentina y por eso tiene una importancia muy fuerte como precedente".

C) En el siguiente ejemplo de sentencia de segunda instancia, vemos con agrado que se aplicó el Derecho Internacional de los Derechos Humanos, aunque hicieron pesar la carga probatoria a la víctima cuando mayormente en el mundo se aplica el concepto contrario, pero teniendo en cuenta la situación real del país, debemos considerarlo un avance, aunque quedan más pasos por dar: “CNAT, Sala VI- Sentencia Definitiva $\mathrm{N}^{\mathrm{o}}$ 53.965-EXPTE. No8060/96-JUZGADO No 45-AUTOS:"D.J.M, C/S. Y C S.R.L. S/DESPIDO". ... -. SALA VI Sentencia Definitiva No 53.965-EXPTE. Nº060/96- 
JUZGADO No 45-AUTOS:"D.J.M, C/S. Y C S.R.L. S/DESPIDO"-Buenos Aires, 15 de marzo de 2001.”.

D) "Viernes, 30 de Diciembre de 2011 Jurisprudencia-Acoso Sexual-Denuncia de la trabajadora-Despido Discriminatorio" FUENTE: REVISTA JURISPRUDENS-21 de Septiembre de 2011 - Cámara Nacional de Apelaciones del Trabajo - Sala I -P., S. L. contra La Pompeya SA sobre Despido--Cita RJ: EBAAA3603. Abstract: La Cámara Nacional de Apelaciones del Trabajo admitió la demanda por despido discriminatorio, ya que se acreditó que la actora fue despedida del frigorífico donde trabajaba luego de denunciar que el gerente de la empresa la acosaba sexualmente, máxime cuando se demostró que sufría situaciones incomodas, ya que dicho gerente la miraba de un modo libidinoso, le profería comentarios impropios, y observaba pornografía delante de ella... la no discriminación cuenta con sustento constitucional, cuando el trabajador se siente discriminado por alguna de las causas, el "onus probando" pesa sobre el empleador por la dificultad que existe para el trabajador de probar la discriminación, mientras que no es así para el empleador, que debe probar la justa causa ("Sendoya Josefina c. Travel Club SA” -DT- Año LXV N5 Mayo 2001, Buenos Aires: La Ley)”. En este ejemplo que dimos, se observa el cambio de onus probandi, es decir, de la carga de la prueba, ahora en cabeza del acusado. Otro paso más dado en materia de derechos humanos.

\subsection{DERECHO COMPARADO}

Para tener una visión de la manera cómo se ha abordado el problema del acoso sexual en el trabajo en las distintas latitudes, se agrupa por regiones dicho tratamiento: -América del Norte:

En los Estados Unidos, las resoluciones judiciales sobre el tema parecen variar en el transcurso de cada decenio: a mediados de los años setenta se intentó recurrir por primera vez a la protección del título VII en caso de insinuaciones verbales y físicas repetidas de carácter sexual contra empleadas por parte de sus superiores como en los casos Barnes v. Train; Corne and De Vane v. Bausch \& Lomb, Inc., y Barnes v. Costle. Aunque los tribunales inferiores adoptaron una actitud tradicional, las instancias de apelación se mostraron dispuestas a ponerse del lado de las víctimas a condición de que pudieran demostrar que los hechos denunciados tenían repercusiones sobre su situación 
en el trabajo. En el caso Corne and De Vane v. Bausch and Lomb, Inc., el Tribunal Federal de Primera Instancia de Arizona se negó a declarar culpable al empleador porque la conducta de hostigamiento del superior no obedecía a la voluntad de la empresa y ésta no la favorecía en absoluto. Dicho tribunal consideró que la conducta en cuestión era una «inclinación o peculiaridad personal». En cambio, dos años después, en el caso Barnes v. Costle, el Tribunal Federal de Apelación del Distrito de Columbia estableció que el despido de una trabajadora por negarse a aceptar proposiciones sexuales equivalía a discriminación sexual porque era perjudicial para el trabajo. Al introducir la famosa prueba de «si no fuera mujer» (si no fuera mujer, no se le habría solicitado su participación en actividades sexuales), el tribunal consideró que el acoso sexual constituye discriminación por razón de sexo, aunque era necesario que tuviera repercusiones reales sobre el empleo para considerarla una discriminación ilícita. El mismo tribunal dio un paso más en la interpretación de esta ley, en 1981, en el caso Bundy v. Jackson, cuando determinó que podía perseguirse el acoso sexual sin necesidad de demostrar la pérdida de ningún beneficio laboral cuantificable.

El primer caso que llegó al nivel del Tribunal Supremo lo hizo diez años después de los primeros intentos de buscar amparo en el título VII. En el caso Meritor Savings Bank, FSB v. Vinson (1986), el Tribunal Supremo reconoció por unanimidad dos clases de acoso sexual en el trabajo: el acoso quid pro quo (literalmente, «esto por aquello», es decir, el chantaje sexual relacionado con el empleo), en el que un superior jerárquico exige favores sexuales a un subordinado a cambio de que éste mantenga $u$ obtenga alguna ventaja laboral (esta clase de acoso supone abuso de autoridad); y otro tipo más amplio, consistente en insinuaciones sexuales no deseadas u otra conducta verbal o física de índole sexual que tenga por finalidad o efecto interferir de forma ilógica en el trabajo de una persona o crear un ambiente laboral intimidatorio, hostil, abusivo, ofensivo o enrarecido (denominado corrientemente acoso sexual en un «entorno de trabajo hostil»). El segundo tipo de hostigamiento sexual, más amplio, no requiere que el denunciante alegue una pérdida económica cuantificable en forma de pérdida de un ascenso, etc. por haberse negado a ceder a las proposiciones sexuales. Sin embargo, en esta misma ocasión el Tribunal Supremo observó que el acoso sexual tiene que ser lo suficientemente grave o amplio para alterar las condiciones de empleo de la víctima. En 1991, se produjo otro avance de la jurisprudencia gracias al caso Ellison v. Brady. El fallo del Tribunal de Apelación de San Francisco dio la razón a una mujer e introdujo el concepto de «apreciación razonable por parte de la mujer» de la conducta en cuestión, 
concepto que se había examinado ampliamente en publicaciones universitarias estadounidenses sobre el acoso sexual en el trabajo.

Siete años después del decisivo caso Meritor, sentenciado por el Tribunal Supremo, en 1993 otra decisión unánime de dicho tribunal volvió a constituir un nuevo progreso jurídico: en Harris v. Forklift Systems Inc., los jueces sentenciaron que la víctima no tenía que demostrar la existencia de ninguna crisis psicológica concreta para justificar una denuncia de acoso sexual por entorno hostil. Este fallo también sirvió para volver a aplicar la prueba llamada de la persona sensata para decidir si una conducta resultaba improcedente. También en 1993, el Tribunal Supremo de Nueva York, en el caso Starishevsky v. Hofstra University, examinó el problema del acoso sexual en el trabajo a raíz de una denuncia en la que se pedían medidas inhibitorias en virtud de la legislación sobre la enseñanza. Sentenció que el procedimiento interno estaba viciado por defectos e incorrecciones de procedimiento, de forma que el despido del acosador, miembro del claustro académico, carecía de validez. Asimismo, frenó la tendencia a sancionar severamente a los acosadores que abusan de sus cargos explicando que la doctrina denominada «a su libre albedrío» (relativa al derecho de los empleadores a contratar y despedir libremente) no otorga a ningún empleador un derecho ilimitado a dar por finalizada sin contraprestación la relación laboral de un trabajador.

El Tribunal de Apelación de los Estados Unidos examinó en 1994 otro caso en el que una universidad mostró una actitud más severa contra los acosadores. En el caso Karibian v. Columbia University (Nueva York, 1994), la demandante había perdido el pleito ante el tribunal de primera instancia sobre la base de las dos teorías para determinar el acoso sexual, a saber, la del quid pro quo y la del entorno laboral hostil. En su sentencia en favor de la universidad, el tribunal sostuvo que dicha institución docente no podía ser culpable en virtud de la teoría del quid pro quo porque la demandante no había demostrado que hubiese sufrido ninguna pérdida económica como consecuencia del acoso de su superior. El tribunal rechazó asimismo la teoría del entorno de trabajo hostil porque la universidad desconocía la existencia de dicho acoso y además había establecido un sistema razonable para denunciar esos casos. En su casación de la sentencia, el Tribunal de Apelación alegó en primer lugar que la empleada no estaba obligada a presentar pruebas de la existencia real, y no de una simple amenaza, de pérdida económica para obtener una sentencia favorable por acoso 
sexual quid pro quo; y que la obligación de demostrar la existencia de una pérdida económica real en los casos en que el empleado se someta a las proposiciones sexuales no deseadas del superior hace excesivo hincapié en la respuesta de la víctima, cuando en realidad la atención debería centrarse en la conducta prohibida. En segundo lugar, hizo valer que el tribunal inferior no había aplicado la norma jurídica adecuada para establecer la responsabilidad del empleador como consecuencia del entorno de trabajo hostil creado por un superior. Puntualizó asimismo que es justo afirmar que el empleador es responsable porque, como mínimo, el superior actúa manifiestamente con la autoridad que la empresa le ha delegado.

Por ejemplo, en el caso Sexton v. AT\&T(1992) un tribunal de primera instancia rechazó la pretensión de la demandante de que no había ascendido porque no había accedido a las proposiciones de su superior, lo que había provocado un entorno laboral hostil. El tribunal determinó en primer lugar que la trabajadora no había afirmado que el acosador, directa, indirecta o remotamente, hubiese hecho algo más que insinuaciones improcedentes, y que era una persona con la que ella al parecer se encontraba bien a solas. A juicio del tribunal, la demandante tampoco aportaba mejores pruebas en relación con el criterio del entorno hostil ya que para que éste exista la conducta reprochable tiene que ser suficientemente grave o generalizada para alterar las condiciones de empleo de la presunta víctima y crear un entorno abusivo. En el caso del que se trataba, las observaciones desdeñosas del acusado, su impaciencia y sus bromas acerca de su relación con otras personas, aunque demostraban falta de profesionalidad, no constituían pruebas de que su comportamiento fuese tan constante y abrumador como para resultar «hostil». El tribunal añadió que su sentencia no se basaba únicamente en la insuficiencia de pruebas sobre el hostigamiento sexual o el perjuicio laboral, sino que además tenía en cuenta que, una vez notificadas las acusaciones, la empresa había adoptado las medidas correctivas adecuadas.

También en los Estados Unidos algunos casos recientes han mostrado una tendencia a pedir grandes cantidades en concepto de indemnización por acoso sexual, así como a que diferentes jurisdicciones obliguen a las partes culpables a adoptar y aplicar medidas que eviten la repetición de esos incidentes. En el caso Robinson v. Jacksonville Shipyards, Inc.(1991), la demandante por entorno de trabajo hostil ganó el pleito, lo que le supuso el resarcimiento de los costos legales y la supresión del acoso por mandato judicial, pero no una indemnización monetaria. El tribunal decidió que Jacksonville Shipyards tenía que adoptar las medidas a su alcance para controlar el 


\section{[LA PROTECCIÓN INTERNACIONAL DE LOS DERECHOS HUMANOS: CASO DEL ACOSO SEXUAL LABORAL EN

entorno laboral en los buques, incluidas consultas con los armadores para quitar o tapar las fotografías colocadas a bordo y guardar las pertenencias de la tripulación cuando se efectuaran reparaciones. Se instó a Jacksonville Shipyards a que no sólo pusiera fin al entorno hostil que había originado el acoso sexual, sino que además aplicara los principios en la materia que el tribunal había dictado como anexo de su sentencia.

El muy conocido caso de Weeks v. Baker \& McKenzie dirimido por el Tribunal Supremo de California, $1^{\circ}$ de septiembre de 1994, fue sentenciado por un jurado, ya que los juicios con jurado están autorizados en las denuncias efectuadas en virtud del título VII como resultado de la modificación de 1991 de la Ley de derechos civiles de 1964, que también estableció indemnizaciones pecuniarias por valor de 50.000 a 300.000 dólares estadounidenses (según el tamaño de la empresa involucrada). En este caso, el jurado condenó a la empresa, dedicada a asuntos jurídicos, al pago de 7,1 millones de dólares estadounidenses, cantidad que se considera la mayor concedida en esa época.

La mayoría de los comentaristas da cuenta de casos judiciales de importancia decisiva que "han contribuido a definir el problema y a imponer sanciones e indemnizaciones para castigar el acoso sexual en el trabajo, considerado delito punible". Intentamos así evaluar qué países y jurisdicciones de dichos países están haciendo avanzar el derecho (para bien o para mal) mediante la interpretación juridical de las disposiciones legales relativas al acoso sexual en el trabajo. Además, poner de manifiesto que es una cuestión jurídica de plena actualidad, como lo demuestran las resoluciones que se reseñan, tomadas de los casos más significativos acaecidos desde 1990 en Canadá y en Estados Unidos, en Australia, Japón y Nueva Zelandia, en España, Francia, Irlanda y Reino Unido, y en Côte d'Ivoire y Sudáfrica.

En Canadá, aunque la legislación laboral, tanto a nivel federal como provincial, tipifica claramente el acoso sexual en el trabajo como un delito punible independiente, en algunos casos las víctimas han recurrido con éxito al amparo de la legislación de derechos humanos. El destacado caso de Janzen v. Platy Enterprises Ltd. (1989) aclaró que el acoso sexual era una forma de discriminación prohibida por la legislación de derechos humanos en todas las jurisdicciones de Canadá. Este caso se vio en apelación tomando como base la Ley de derechos humanos de Manitoba y siguió la tendencia a recurrir a la legislación de derechos humanos que se inició a principios del decenio de 1980 con el caso Bell and Korczak v. Alders and Flaming Steer Steakhouse. Las 
jurisdicciones de habla francesa de Canadá han adoptado el mismo criterio: en el caso Commission des droits de la personne de Québec c. Marotte, la Comisión de Derechos Humanos de Quebec concedió una indemnización por daños y perjuicios a una mujer en virtud de la legislación provincial pertinente de derechos humanos, si bien indicó que su cuantía habría sido superior si la demandante hubiese presentado pruebas periciales del daño psicológico que había sufrido como consecuencia de la conducta ofensiva.

En cambio, en 1991, en el caso Chaw v. Levac Supply Ltd. un órgano de investigación de Ontario expresó una opinión más amplia sobre lo que constituye acoso sexual. Afirmó que comentarios negativos y ofensivos de carácter sexual, así como el comentario de que las mujeres tendrían que quedarse en casa cuidando a sus hijos, constituyen conductas equiparables al acoso sexual. En lo que se refiere a las decisiones arbitrales que toman como base las disposiciones de los convenios colectivos, merece señalarse que en Canadá se han registrado progresos en los aspectos de procedimiento y sustantivos de las denuncias por acoso sexual: en muchos casos se requiere que la carga de la prueba de que no ha habido hostigamiento recaiga sobre el presunto autor una vez efectuada la denuncia.

\section{-Sudáfrica:}

Algunos comentaristas afirman que la Constitución Provisional de Sudáfrica (Ley núm. 200, de 1993) permite presentar demandas judiciales por cuanto garantiza una conducta laboral equitativa y prohíbe, entre otras cosas, la discriminación por razón de sexo, al igual que la Ley de seguridad e higiene en el trabajo (núm. 85, de 1993), en virtud de la cual los empleadores tienen que adoptar las medidas que sea posible aplicar razonablemente para reducir o suprimir todo peligro o posible peligro para la salud o la seguridad de los trabajadores (artículo 8.2, b)).

\section{-Europa:}

Reino Unido, como ya hemos señalado antes, cuyo Reglamento de la protección del empleo y contra la discriminación sexual (medidas de resarcimiento), de 22 de noviembre de 1993, suprimió el anterior límite máximo de 1.000 libras esterlinas de indemnización a las víctimas de discriminación sexual, con el fin de ajustar la situación en el país a la decisión del Tribunal de Justicia Europeo.

Por consiguiente, ¿cómo han reaccionado ante estas nuevas leyes los tribunales de diferentes jurisdicciones? En la década de 1990 sólo ha habido sentencias en muy 
pocos casos, lo que no resulta sorprendente habida cuenta de que muchas de las leyes mencionadas no se aprobaron o entraron en vigor hasta 1995. No obstante, la OIT (1995) menciona varios casos importantes en diversos países.

En el Reino Unido muchos comentaristas han descripto la aplicación de la Ley contra la discriminación sexual de 1975 y del apartado c) del párrafo 2 del artículo 55 de la Ley de protección del empleo de 1978 en casos de denuncia de acoso sexual. Baste con recordar aquí que el caso Porcelli v. Strathclyde Regional Council (1985) representó la primera victoria en un asunto de acoso sexual. El Tribunal de Apelación de Escocia (Court of Session) falló en favor de una especialista de laboratorio después de tres juicios orales. El tribunal laboral había llegado a la conclusión de que, pese a haber habido cierto grado de acoso sexual por parte de los compañeros de la denunciante, éstos habrían tratado igualmente mal a un hombre que no les gustara. El Tribunal Laboral de Apelación sentenció que los aspectos de la conducta de los denunciados (chistes, insinuaciones, comentarios y gestos) que tenían connotaciones sexuales «podían no tener importancia si se hacían respecto de un hombre», y falló que la mujer se había visto perjudicada en su trabajo al verse obligada a pedir el traslado de la escuela en que trabajaba, y porque tener que hacer frente a un entorno hostil puede bastar para ganar un juicio por acoso sexual. Por último, el Tribunal de Apelación (Court of Session) declara que se juzgaba el tipo de trato y no el motivo que tuviese el acosador; como la conducta incluía elementos de carácter sexual que no se habrían empleado contra una persona del mismo sexo que el acusado (un hombre, en este caso), la denuncia estaba justificada.

Por lo que se refiere a los progresos en materia de interpretación judicial del acoso sexual en el trabajo, 1990 fue un año fundamental. En el caso Bracebridge Engineering Ltd. v. Darby, el Tribunal Laboral de Apelación rechazó el recurso interpuesto por la empresa contra la sentencia de un tribunal de trabajo en favor de una mujer que había sido víctima de conducta ofensiva, sobre la base a la vez de despido implícito y de discriminación sexual. En el caso James v. Eastleigh Borough Council la Cámara de los Lores estableció otro principio general para el Reino Unido en cuanto al acoso sexual, a saber, que no es preciso que exista motivo o intención discriminatoria para que haya discriminación ilícita. Dicho con otras palabras, la afirmación que suele hacer el acosador de que «no pretendía causar ningún daño» puede rechazarse habida 
cuenta del impacto que esta conducta haya tenido sobre la víctima. Este criterio es parecido al adoptado por los tribunales de los Estados Unidos, descripto anteriormente, que recurren a la prueba de las «consecuencias para la víctima» y no a la mens rea (intención) del acusado. Sin embargo, en 1994 el Tribunal Laboral de Apelación no aplicó la Ley sobre acoso sexual en el caso de Steward v. Cleveland Guest (Engineering) Ltd. Mantuvo el fallo de un tribunal de trabajo de que las fotografías de mujeres en un contexto sexual no equivalen a un trato menos favorable de la mujer por razón de su sexo, afirmando que los hombres sensibles también se sentirían ofendidos, siguiendo así la tendencia establecida por otros tribunales de apelación de no interferir en los fallos de los tribunales laborales a menos que sean irracionales, ilógicos o ciertamente injustos.

En el párrafo 1 del artículo 41 de la Ley contra la discriminación sexual de 1975 se establece que la simple ignorancia del empleador de que se ha producido acoso sexual no es suficiente para eludir la posibilidad de responsabilidad subsidiaria, caso Aldred v. Nacanc, 1987.

Por ejemplo, en Francia el Tribunal de Apelación de Versalles en el caso Mlle. $X$ c. Sté. Y, Onzième Chambre social de la Court d'appel de Versailles, París, 30 de junio de 1993, confirmó la decisión de un tribunal laboral, de 23 de octubre de 1991, de que el hecho de enviar poesías apasionadas y cartas de amor sin expresiones indecentes ni obscenas no constituía una base suficiente para considerar que hubiese habido acoso y que, por consiguiente, la no renovación del contrato de la persona que las había recibido equivalía a su dimisión y no a un despido injustificado. Otro caso es el de un Tribunal Laboral de Abidján (Côte d'Ivoire) resuelto por el Tribunal de Trabajo de Abidján, en el caso Kouame Koffi c. La librairie de France, por decreto núm. 1119, 8 de mayo de 1991, que falló en favor de una víctima de acoso que afirmó que su despido era injusto, por lo que condenó al empleador a pagar 200.000 francos CFA en concepto de daños y perjuicios más una indemnización por terminación del contrato, al considerar que el motivo del despido aducido por el empleador (ausencia del trabajo durante 40 minutos) constituía un simple pretexto y que la verdadera razón residía en que la víctima se había afiliado a un comité recientemente constituido en la empresa para denunciar los abusos homosexuales de uno de los directores. Esta sentencia fue anulada en apelación, al establecerse que el motivo del despido fue la ausencia durante cuarenta minutos (aunque el tribunal reconoció que esta ausencia se debía a la afiliación del empleado al citado 
comité), por el Tribunal de Apelación de Abidján, en el caso Kouame Koffi c. La librairie de France, por decreto núm. 643, 22 de mayo de 1992.

Como ya queda dicho, la legislación francesa circunscribe el hostigamiento sexual al abuso de autoridad. En cuanto a la jurisprudencia, una de las tendencias francesas es que el tribunal haga un exámen estricto de los hechos para dilucidar si el comportamiento del acusado debe calificarse de acoso no deseado. Una decisión significativa fue la adoptada en 1992 sobre el caso Manpower France c. Defadat, en el que un tribunal inferior declaró que era difícil determinar el límite pasado el cual los chistes y las expresiones de mal gusto se convierten en acoso sexual. El criterio del tribunal de apelación quedó confirmado posteriormente ese mismo año en el caso EuroDisney, pues dicho tribunal ratificó la decisión de la empresa de despedir a un acosador homosexual debido a sus insinuaciones y comentarios sexuales, contrarios a la decencia. En Francia, la tendencia en lo que respecta al resarcimiento consiste en condenar al pago de daños y perjuicios - acompañado en ocasiones de una indemnización punitiva ejemplar - más los intereses-, en lugar de proceder a la readmisión del trabajador, por ejemplo en los casos de Société bourguignonne de supermarchés c. Pascal y de SA Rockwell International c. Loiseau.

En 1990, en un caso juzgado ante el Tribunal de Apelación de Nancy - Risse c. Chardin 58 -, éste determinó que la complacencia de la víctima (que podía considerarse debida a diversos factores, entre ellos el temor al escándalo si denunciaba el acoso) no debía tenerse en cuenta para evaluar las pruebas de que la conducta denunciada equivalía a un abuso de autoridad en forma de acoso sexual prohibido.

No se sabe que haya habido casos importantes en Irlanda, pero es interesante señalar que los tribunales laborales han dictado sentencias notablemente progresistas. Por ejemplo, en el caso de «una empresa y un trabajador » (nombres dados por el tribunal) (1990) se alegó que una relación sexual voluntaria entre adultos había acabado, por lo que el consentimiento inicial no justificaba que se produjeran posteriormente actos semejantes entre las partes. En consecuencia, la mujer ganó el pleito en virtud de lo dispuesto en el párrafo 4 del artículo 3 de la Ley de igualdad en el trabajo, de 1977. No obstante, para decidir la cuantía de la indemnización el tribunal laboral tuvo en cuenta su «imprudencia» por ponerse en peligro y no pedir ayuda exterior antes de denunciar el caso. 
Un alud de casos de acoso sexual registrados en España durante el decenio de 1990 presenta dos características notables: los tribunales laborales han fallado constantemente en favor de las víctimas, aplicando las disposiciones del Estatuto de los Trabajadores de 1980 (apartado e) del número 2 del artículo 4 y artículos 54 y 55) y la Ley de procedimiento laboral de 1995 (artículos 180 y 181). En cambio, los tribunales de apelación han preferido revocar esas sentencias o disminuir la indemnización. Un ejemplo de la primera característica lo dio un juzgado de lo social de Barcelona, en una sentencia de 1991: al amparo del apartado e) del número 2 del artículo 4 del citado Estatuto de los Trabajadores, falló en favor de una mujer sometida a acoso sexual en el lugar de trabajo ya que el gerente de la empresa espiaba regularmente a las trabajadoras a través de orificios efectuados en el tabique que separaba los servicios de hombres y mujeres.

En otros dos casos de 1995 (ambos entendidos por mujeres jueces), sendos juzgados de lo social de Madrid declararon nulos y sin efectos los despidos de trabajadoras, al no haber demostrado las empresas empleadoras que el despido tuviera otro motivo que el denunciado por las mujeres, es decir, el acoso sexual por parte de superiores. En ambos casos se ordenó la readmisión inmediata con el abono total de las remuneraciones y prestaciones dejadas de percibir desde la fecha del despido injustificado. El Juzgado de lo Social de Cádiz rechazó el recurso de un demandante despedido por acoso - que protestó alegando que en la carta de despido no se le habían notificado los motivos del mismo - ya que era evidente que sabía que su conducta equivalía a acosar sexualmente a sus subordinadas. Como ya se ha mencionado antes, diversos comentaristas y el fallo en por lo menos un caso plantean el acoso sexual como una vulneración de las obligaciones del empleador en materia de seguridad e higiene en el trabajo. Así, una sentencia del Tribunal Superior de Justicia de Castilla-La Mancha reafirmó que la incapacidad sufrida por una trabajadora debido a una agresión sexual de un compañero efectuada en el lugar de trabajo equivalía a la incapacidad laboral transitoria derivada de accidente de trabajo, y no a una enfermedad común, por lo que se podía solicitar indemnización en virtud del Estatuto de los Trabajadores. En lo que respecta a sentencias dignas de señalar de tribunales de apelación que imponen sanciones y reparaciones, la del 23 de agosto de 1994. El Tribunal Superior de Justicia de Galicia - aun reafirmando la sentencia inicial de que hubo acoso sexual - redujo de 1.500 .000 a 500.000 pesetas la cuantía de la indemnización concedida a la mujer víctima de acoso sexual verbal, alegando que la carga de la prueba no correspondía al 
trabajador individual sino que era responsabilidad de la empresa. Cabe citar otras sentencias del Tribunal Superior de Justicia de Galicia en 1995: 1) reducción a 600.000 pesetas de la indemnización de 7 millones por daños morales, y anulación, «por ser absolutamente desproporcionado», del pronunciamiento de condena por daños físicos de 1 millón de pesetas; 2) reducción a 150.000 pesetas de una indemnización de 1 millón cuando una ayudante de cocina que había ganado un pleito por acoso sexual apeló solicitando una indemnización de 10 millones de pesetas; y 3) anulación de una indemnización de 775.000 pesetas - aun afirmando que la conducta del director de la empresa constituía en parte una agresión sexual - sobre la base de que el acoso no produjo el trastorno ni la perturbación mental alegadas, ya que la mujer que había sido víctima de este acoso había continuado manteniendo relaciones de amistad con el acusado.

En Bélgica, en una sentencia de 1991 relativa también a si podía considerarse que los hechos constituían acoso sexual, el Tribunal Laboral de Apelación de Lieja confirmó una decisión de un tribunal de trabajo que consideraba injustificado el despido de una empleada que afirmaba que el motivo real de la extinción de su contrato se debía a que se había quejado por escrito sobre el acoso sexual que presuntamente había sufrido por parte del director. El tribunal determinó que, habida cuenta de que el empleador no había aportado pruebas en contra de la denuncia, ni aducido ningún motivo real que justificase el despido, la denunciante tenía derecho a reparación según la Cour d'appel de Liège, Chambre de droit social, sentencia de 16 de enero de 1991. Otra observación inicial de carácter general es que pocas sentencias de los tribunales de las jurisdicciones estudiadas se remiten a las normas internacionales que podrían aplicarse en los casos de hostigamiento sexual. Aunque en los últimos veinte años ha habido una tendencia a aplicar el derecho internacional, en especial las normas de la OIT, en la jurisprudencia nacional esta tendencia no se observa en la esfera aquí examinada. Los comentaristas indican en general que la legislación no siempre resulta clara en las jurisdicciones internas a las que se refieren, pero éstas no piden que los órganos de las Naciones Unidas y los órganos regionales que podrían prestar atención al acoso sexual lo tengan en cuenta en sus programas normativos. Así pues, la falta de normas internacionales específicas sobre este tema podría explicar en parte la falta de 
confianza en las normas internacionales que ponen de manifiesto las sentencias nacionales en materia de acoso sexual.

-Chile:

Del mismo modo en Chile, el Superior Tribunal de la provincia de Santa Fe (Publicado en Mujer/Fempress (Santiago de Chile), núm. 143, septiembre de 1993) confirmó la conclusión del juzgado de primera instancia de que, a pesar del testimonio de varias mujeres con respecto a la conducta lasciva de un juez, no existían pruebas de que hubiese habido acoso sexual, y que el testimonio se basaba totalmente en rumores. El juez, que había sido suspendido durante la apelación, pudo posteriormente volver a ocupar su puesto.

\subsection{CASOS RESUELTOS POR LA COMISIÓN Y LA CORTE INTERAMERICANA DE DERECHOS HUMANOS (OEA)}

No hemos podido hallar ningún caso que en relación a nuestro tema del acoso sexual laboral, haya sido resuelto por la Corte Interamericana de Derechos Humanos, pero sí existe una demanda caso $\mathrm{n}^{\circ} 13.376$ que recientemente fue admitida ante la Comisión Interamericana de Derechos Humanos y ahora se está estudiando sobre el fondo de la cuestión, presentada en el año 2002 (expediente de origen $n^{\circ}$ P-279-02) de denuncia contra el Estado Argentino por negación de justicia basada en el mismo tema, una vez agotados en la instancia interna todos los procedimientos. Dicho caso fue presentado por esta Maestranda.

\section{4 ÚLTIMAS PALABRAS}

A pesar de la escasez de sentencias recientes de alto nivel (tribunales supremos o constitucionales) en la esfera del hostigamiento sexual en el trabajo, los casos descriptos confirman las tendencias existentes en las diversas jurisdicciones, así como los avances significativos del derecho logrados mediante las sentencias de los tribunales. Será interesante observar si dentro de diez años estas tendencias se han detenido, han continuado o han progresado en algunas esferas importantes, tales como la elección de tribunal, la responsabilidad del empleador y las sanciones y recursos. ¿Qué ponen de manifiesto las diferentes sentencias en lo que respecta al avance del derecho en el ámbito del acoso sexual en el trabajo? En primer lugar, que muchas jurisdicciones adoptan el criterio de los tribunales de los Estados Unidos, a saber, que el hostigamiento 
sexual debe tipificarse como una forma de discriminación por razón de sexo que supone un obstáculo a la integración de la mujer en el mercado laboral. En este sentido, las sentencias estadounidenses han ejercido gran influencia sobre las de otros países. Sin embargo, los criterios jurídicos nacionales siguen siendo notablemente diferentes: Francia recurre a sanciones penales, España se basa en la legislación sobre seguridad e higiene en el trabajo y en Sudáfrica se debate actualmente si es necesario demostrar que hubo intención delictiva para determinar la responsabilidad, todo lo cual indica que los diferentes sistemas jurídicos están dispuestos a ensayar caminos jurídicos distintos para poner coto a los comportamientos inaceptables. Una segunda conclusión es que, según el tipo de marco jurídico utilizado, las víctimas de acoso pueden obtener resultados muy distintos. La legislación sobre igualdad de oportunidades en materia de empleo puede resultar ventajosa para los demandantes porque suele existir un procedimiento judicial previamente establecido y porque los órganos especializados que tienen experiencia práctica en materia de discriminación por razón de sexo pueden juzgar mejor los hechos que se les presenten y los fundamentos jurídicos del derecho vigente para pronunciar sus sentencias. En los países en que el acoso sexual se considera un asunto de derecho laboral, el impacto de la ley puede limitarse a los casos de hostigamiento de tipo quid pro quo, obligando así al demandante a demostrar la existencia real - o, más recientemente, la amenaza - de inconvenientes laborales por causa de conductas improcedentes. En algunos países europeos se invocan las disposiciones del derecho del trabajo relativas al despido implícito y al despido injustificado para proteger a las víctimas de acoso sexual. El recurso al derecho penal para este fin resulta a menudo un camino difícil debido a las estrictas normas que exigen demostrar los hechos de manera fehaciente y a que, en la mayoría de los países que aplican la presunción de inocencia, la carga de la prueba corresponde exclusivamente a la parte que formula la acusación (Estudio general de 1996 de la Comisión de Expertos en Aplicación de Convenios y Recomendaciones de la OIT, se considera muy conveniente liberar al denunciante de la carga de la prueba cuando ha presentado indicios razonables). Otro aspecto de la elección de jurisdicción se refiere a la composición del órgano que decidirá sobre el caso. Se observa que en todo el mundo los tribunales compuestos por jueces masculinos adoptan criterios estereotipados en los casos de acoso sexual. Así vemos sentencias dictadas incluso durante el decenio de 1980: en los Estados Unidos, en el caso Rabidue 
v. Osceola Refinery $C O$, una apreciación evidentemente sesgada por razón de sexo del testimonio de las partes tuvo por consecuencia la aplicación sexista de la ley. Otro elemento importante son las cuestiones de procedimiento fijadas en las distintas jurisdicciones. En primer lugar, la demanda suele tener que presentarse dentro de un plazo determinado. Por ejemplo, en el Reino Unido la legislación impone el límite de tres meses a partir de la fecha del presunto incidente o conducta para incoar la acción ante un tribunal laboral. En lo que se refiere a la duración de las actuaciones, algunas jurisdicciones son mejores que otras. Los casos de que se ocupa la Comisión de Oportunidades de Empleo del Reino Unido tardan por término medio dos años en llegar al Tribunal de Apelación. En Canadá, las comisiones de derechos humanos son notablemente lentas en conocer todos los casos de su competencia, y no únicamente los de acoso sexual. En Estados Unidos, la presentación de quejas ante la EEOC en virtud del título VII de la Ley de derechos civiles de 1964 prescribe a los 180 días. Por esta razón, se afirma que los procesos civiles suelen ser más rápidos, ya que pueden entablarse directamente sin necesidad de agotar los recursos administrativos como les sucede a los demandantes con arreglo al título VII. Otro aspecto procesal es el de las pruebas admisibles para sostener la queja: en Francia en los procesos penales se aceptan pruebas tales como las cintas magnetofónicas, que no se admiten con facilidad en otros sistemas jurídicos. Los tribunales suelen tener la facultad de declarar una audiencia pública o a puerta cerrada.

Algunos comentaristas afirman que la jurisprudencia ha tardado mucho en fomentar la protección contra el acoso sexual en el lugar de trabajo. Otros consideran que el impulso jurídico proporcionado por las sentencias del Tribunal Supremo de los Estados Unidos ha obligado a muchísimas empresas a idear y aplicar estrategias para hacer frente al problema.

La cuestión de la responsabilidad es otro tema importante y motivo de discrepancia en gran parte de la jurisprudencia sobre acoso sexual. Si se prueba la responsabilidad del empleador, el demandante tendrá probablemente mayores posibilidades de conseguir una indemnización pecuniaria y el empleador se sentirá abocado a aplicar normas estrictas en la empresa para impedir el acoso sexual. Si se dictamina la responsabilidad individual del autor del acoso, la persona demandante puede considerarlo una victoria personal que constituirá un poderoso mensaje dirigido a los acosadores potenciales, en el sentido de que serán responsables personalmente del pago de la indemnización que fije eventualmente el tribunal en caso de que sean 
llevados a juicio, y por consiguiente su conducta será más respetuosa. Si puede establecerse la responsabilidad tanto del acosador como del empleador, las ventajas serán dobles. La responsabilidad varía con arreglo al tipo de legislación: es diferente según se apliquen leyes relativas a la igualdad de oportunidades en el trabajo, leyes laborales, leyes penales o el Código Civil (esta última vía es la más tratada en las publicaciones teóricas). Los casos estudiados indican que, si se aplica la legislación relativa a los derechos humanos y a la discriminación por razón de sexo en general, el empleador será responsable de indemnizar a la víctima si la ley prohíbe la discriminación sexual «por parte del empleador», y lo será el acosador si la ley prohíbe esa discriminación «por parte de cualquier persona». No obstante, en esta última hipótesis el principio de responsabilidad subsidiaria significa a menudo que el empleador es responsable siempre, independientemente de que el acoso lo hayan cometido superiores de la víctima, compañeros de trabajo o personas no empleadas en la empresa.

Algunos países tienen una legislación muy escrupulosa al respecto: en el párrafo 1 del artículo 41 de la Ley británica de 1975 contra la discriminación sexual se declara que el autor de acoso sexual prohibido puede ser un empleador o cualquier persona bajo su mando y, como se ha señalado anteriormente, la jurisprudencia ha establecido que la simple ignorancia de la existencia de determinada conducta en el lugar de trabajo no basta para eludir la posibilidad de responsabilidad subsidiaria.

En el derecho laboral español, el empleador casi siempre ha sido considerado corresponsable, porque las disposiciones legislativas de que se trata están redactadas de forma que establecen su responsabilidad respecto de sus empleados. En las acciones civiles las personas son responsables de sus propios actos, pero en casos de esta clase se ha logrado extender la responsabilidad subsidiaria al empleador, además de la que tenga el acosador. El derecho penal sólo reconoce la responsabilidad del acosador, y además el procedimiento criminal tiene el inconveniente de que suele ser largo, requerir el exámen contradictorio de todas las partes y ser instado por unas fuerzas de policía que tal vez no hayan recibido formación para manejar con sensibilidad esos casos. Como se observa en algunos casos canadienses, determinadas jurisdicciones provinciales autorizan a la presunta víctima a llevar directamente ante los tribunales al acosador o a reclamar ante una de las comisiones de derechos humanos, que pueden incoar el proceso 
en nombre del demandante. La responsabilidad también puede depender del tipo de acoso. La experiencia de los Estados Unidos pone de manifiesto que si bien la responsabilidad del empleador suele declararse en casos de hostigamiento quid pro quo, no ocurre así necesariamente en los casos de acoso por entorno hostil.

Por último, la cuestión de las sanciones y resarcimientos constituye una de las características más notablemente comunes en los casos registrados últimamente en todo el mundo. A nivel de procedimiento interno, la sanción más corriente es la medida disciplinaria adoptada por el empleador en forma de reprimenda, traslado, reducción de salario o grado, retraso en el ascenso, supresión del aumento salarial anual (en especial en el sector público), degradación, suspensión, o incluso despido.

En Canadá, los convenios colectivos suelen autorizar a las juntas arbitrales a imponer sanciones pecuniarias a los acosadores; los convenios de Dinamarca, Italia, Países Bajos y Reino Unido también empiezan a establecer disposiciones de carácter general contra el acoso sexual en el trabajo. Serna Calvo (1994) señala que en algunos convenios colectivos de España se prohíbe el acoso sexual, pero a menudo no se define esa conducta y no se trata la cuestión del cumplimiento y las sanciones. En Estados Unidos, las indemnizaciones concedidas a las trabajadoras (1991) suelen ser irrelevantes, porque sólo se resarcen los gastos en prestaciones médicas y las pérdidas de ingresos consiguientes al acoso sexual cuando, en realidad, la mayoría de las víctimas no tienen gastos médicos, o los que tienen son insignificantes, ni sufren pérdidas de remuneración, especialmente en las denuncias por entorno laboral hostil. Por otra parte, los tribunales suelen recurrir al principio de proporcionalidad para evaluar los daños y perjuicios, como puede observarse en las sentencias de 1995 de los tribunales de apelación españoles. Los tribunales pueden ordenar la readmisión con o sin el pago de remuneraciones y prestaciones atrasadas, así como dictar interdictos y otros mandamientos judiciales que requieran al empleador poner fin a la conducta denunciada, medidas que suelen verse acompañadas de una orden de llevar a cabo determinados actos para reparar el daño causado. Esto puede hacerse proporcionando formación o adoptando y aplicando medidas específicas contra el acoso sexual, o bien sensibilizando en general a los trabajadores, como ocurrió en los Estados Unidos en 1991 en el caso Robinson v. Jacksonville Shipyards, Inc. En el Reino Unido, en el apartado $c$ ), párrafo 1, del artículo 65 de la Ley contra la discriminación sexual de 1975 también se prevé el traslado laboral del acosador. La forma más habitual de resarcimiento, a gran distancia de las demás, es la constituida por las sentencias de 
indemnización pecuniaria por daños y perjuicios para compensar una pérdida monetaria real o un daño moral. La posibilidad de resarcir los daños inmateriales es importante, ya que, en caso contrario, la víctima no recibiría compensación económica de no haber sufrido ninguna pérdida pecuniaria. Ahora bien, como se ha señalado en algunos de los casos descriptos, en la mayoría de las jurisdicciones de habla inglesa ya no se exige la prueba de que haya habido perjuicio o detrimento laboral cuantificable.

En los Estados Unidos se registró una novedad interesante en lo que respecta a la concesión de indemnizaciones por perjuicios morales: el 22 de mayo de 1996, la Cámara de Representantes aprobó la Ley de protección del empleo en la pequeña empresa, en la que se prevé modificar el Código Fiscal con el fin de autorizar la percepción de impuestos sobre las indemnizaciones por daños morales obtenidas por las víctimas de acoso sexual u otras formas de discriminación en el empleo o conducta delictiva en el trabajo. Hasta ese año, las indemnizaciones (excepto algunas de tipo punitivo) obtenidas en concepto de daños personales o enfermedad estaban exentas con arreglo al indicado Código.

Resulta evidente la importancia de saber claramente qué se espera conseguir cuando se presenta una denuncia por acoso sexual, sea cual fuere el tipo de legislación o el tribunal de que se trate, independientemente del resarcimiento o la sanción que se solicite. 


\section{Capítulo VI. CONCLUSIÓN}

En tanto que definimos en el Capítulo I las teorías que utilizamos, en el siguiente dimos el marco conceptual y en el Capítulo III el marco jurídico; los dos capítulos siguientes fueron necesarios para desarrollar los fundamentos de nuestra hipótesis.

Si nuestros objetivos fueron los siguientes, recordemos:

1) GENERAL: Analizar el desarrollo de los procesos de aplicación y protección jurídica de las normas internacionales de derechos humanos emanadas de la OEA y de la ONU contra el acoso sexual laboral, en la Administración Pública en Argentina y del derecho comparado de los países más relevantes de la región americana (Ejemplo: E.U, países latinos) y europea para detectar las razones de las tendencias de éxito o fracaso de aquellas en su derecho interno.

2) ESPECÍFICOS:

a) Caracterizar la evolución de la normativa sobre el acoso sexual laboral en Argentina y en los países más avanzados sobre el tema para comprobar los intereses que motivaron el éxito o el fracaso de sus normas.

b) Describir las políticas públicas de Argentina para desentrañar su modelo de inserción internacional en el universo de los derechos humanos.

c) Explicar el impacto de las políticas públicas en materia de acoso sexual laboral de Argentina más relevantes para comprender el nivel de incidencia que han tenido en el éxito o fracaso en la aplicación de las normas internacionales teniendo en cuenta los resultados al respecto en los países a estudiar.

Llegamos así a la siguiente conclusión con la conformidad de haber alcanzado todos nuestros objetivos. En tanto que respecto de los demás Estados estudiados, el éxito alcanzado reflejado tanto en su proyección legislativa como jurisprudencial interna, se debe a la concientización de sus comunidades sobre el flagelo de la violencia sexual y en especial del acoso sexual laboral para exigir a sus autoridades la protección necesaria y la efectividad de sus sistemas de administración de justicia (Ejemplo: E.U, Canadá, Francia, España, Unión Europea, Puerto Rico, Costa Rica); en los países latinos, desde el año 1988 en Puerto Rico por medio de la Ley n ${ }^{\circ} 17$ se entendió qué era la figura del acoso sexual laboral y se la prohibió; en Costa Rica está la Ley n 7476 del año 1995 que lo prohíbe tanto en el ambiente de trabajo y de educación; en Chile se encuentra en el Código de Trabajo, y en Brasil hay una Ley contra el acoso sexual laboral. El fracaso se da en aquéllos pueblos que aún no han roto sus cadenas de la 
represión cultural y discriminación de que son objeto (caso común en América Latina) las mujeres por fuertes estereotipos discriminatorios ejercidos dentro del sistema por funcionarios públicos y que desciende incluso hasta los empleados que toman las denuncias, tramitan las causas, aseguran el material probatorio, aplican la ley, etcétera. En materia de Acoso Sexual Laboral, las políticas públicas de Argentina no fueron diseñadas, no hay producción legislativa concreta (aunque sí sólo proyectos de sectores opositores en el abandono total) ni mucho menos estadísticas, programas de contención de las víctimas, protocolos de atención, oficinas especializadas, funcionarios capacitados para resolver esas situaciones, forenses capacitados en materia de violencia de género ni de acoso sexual laboral, ni jueces especializados, ni fueros especiales, ni áreas que tengan que ver con el tema dentro del Ministerio Público Penal, ni en oficinas administrativas del Poder Ejecutivo, incluido el propio Consejo Nacional de la Mujer que depende de la Secretaría Ejecutiva del Consejo Nacional de Coordinación de Políticas Sociales de la Presidencia de la Nación, ni siquiera en forma directa de ésta lo que ha sido criticado duramente por la OEA en los informes anexados.

En Argentina, el problema no radica totalmente en el reconocimiento formal de derechos sino en asegurar su ejercicio. Existe la Ley Nacional n ${ }^{\circ} 26.485$ (ratifica la Convención de Belém do Pará) que define el concepto de acoso sexual laboral. En el resto de los Tratados de Derechos Humanos con jerarquía constitucional (art. 75 inc. 22 C.N) no hay definición concreta sobre el particular. No olvidemos que la Recomendación General $\mathrm{n}^{\circ} 19$ (ONU) del Comité para la Eliminación de la Discriminación contra la Mujer también define dicho concepto y las obligaciones para los Estados Partes. Luego de ello, no hay más normas internacionales con ese sentido estricto. No hay producción legislativa en el país más allá de lo mencionado en el Capítulo IV donde desarrollamos el primer indicador que nos prueba la falta del deber de debida diligencia de Argentina, para quien el bienestar del Pueblo no es el mayor fin a lograr con su acción política doméstica y hacia el exterior, al no dejar entrever su voluntad hacia dicho fin, máxime que ya varios Pueblos americanos y europeos, por ejemplo, le llevan décadas de adelanto en el tema de la presente Tesis. Esto revela una voluntad contraria a la firma de dichos Tratados Internacionales de Derechos Humanos, por lo que usamos para interpretar dicha conducta ambigua de Argentina, las teorías opuestas del Idealismo y del Realismo y concluimos que hacia la comunidad 
internacional, se muestra colaboradora y parece abrazar con énfasis dichos Acuerdos lo que marca un cariz Idealista, mientras que en la faz doméstica, es más bien conflictiva por no aplicar sus normas, como lo haría un Estado Realista.

El Indicador "Producción Legislativa" da cuenta del atraso en que se encuentra Argentina en la aplicación efectiva de la Ley $\mathrm{n}^{\circ} 26.485$ si se quiere, o de los propios Tratados referenciados por no haberse multiplicado y expandido sus efectos a todas las provincias del país. Como vimos no hay política de Estado para abarcar el problema como un todo y solucionarlo.

En el Capítulo V hablamos del segundo indicador de nuestra variable independiente, la producción jurisprudencial donde es casi nula la realizada por nuestros tribunales, y si bien existe la primer denuncia penal sobre el tema en el año 1999 en la Provincia de Buenos Aires, la misma no fue investigada, por los estereotipos y discriminación hacia la mujer que marcamos cuando hablamos de la violencia de género. Señalamos el avance del sistema judicial anglosajón, canadiense, francés y hasta el español, entre otros, y la época desde la cual es llevado a juicio este tema, mucho antes que en Argentina, donde aún no se habla ni se legisla y se encajonan los proyectos de partidos opositores. En ese sentido, desde el año 1988 ya nos aventaja Puerto Rico.

El diagnóstico que presentamos con el indicador "Producción Jurisprudencial" sobre el acceso a la justicia para las mujeres víctimas de acoso sexual laboral en Argentina, al igual que en otros países latinos como El Salvador, Guatemala, Honduras y Nicaragua, sugiere que aunque los Estados de la región han realizado importantes avances para abordar y prevenir la violencia contra las mujeres, es aún difícil y revictimizante, lo que lleva a concluir que todas las citadas recomendaciones de los informes descriptos en el Capítulo IV aún no han sido cumplidas integralmente, por lo que, concluímos que la debida diligencia en la prevención, aplicación, control, de las Convenciones Internacionales que hacen a nuestra Tesis, no se ha manifestado, lo que origina responsabilidad para el Estado Argentino en el Derecho Internacional de los Derechos Humanos. Y todo lo analizamos desde la evolución que lograron otros países investigados, donde son más de treinta y seis los que reconocen por ley nacional y prohíben el acoso sexual laboral, no así aún en Argentina.

Nuestra variable dependiente fue también lograda y comprobada a medida que investigamos los aportes legislativos y jurisprudenciales hechos en el campo doméstico de cada país en los Capítulos IV y V. 
Probamos así que Argentina es país infractor en materia de Derechos Humanos en lo que hace al acoso sexual laboral, al no crear una ley nacional específica sobre ello, ni incorporar a su legislación interna los fallos, disposiciones y resoluciones de los organismos internacionales americanos a los que estamos unidos por Tratados de rango constitucional, a pesar de haber sido incorporados en la Constitución Nacional en el año 1994 los Tratados de Derechos Humanos en el art. 75 inc 22, explicándose ello además en la falta de leyes locales y en la falta de reglamentación de la Ley provincial $\mathrm{n}^{\circ} 12.764$ -provincia de Buenos Aires- de autoría de esta maestranda; de capacitación de la administración de justicia ante denuncias sobre el tema, de procedimientos laborales de cómo actuar tanto a nivel de empleo privado como público, de falta de políticas públicas, de organismos especializados que traten la solución al problema desde el punto de vista de la víctima, social, a nivel comunidad, etcétera. Y de la falta de aplicación cuando se debe recibir una denuncia y sentenciar conforme a las normas internacionales e incluso ya respecto de la jurisprudencia avanzada en otros países.

Se reconoce por la Comisión Interamericana de Derechos Humanos, la ausencia de un compromiso real de los Estados americanos de prevenir, investigar, sancionar y ofrecer una efectiva reparación a estos actos. A pesar del reconocimiento formal y jurídico de los Estados, aún existe una gran brecha entre la incidencia y la gravedad del problema y la calidad de la respuesta judicial ofrecida. Y si bien la Comisión reconoció los esfuerzos de los Estados en la adopción de un marco jurídico y político para abordar la violencia contra las mujeres, señaló que aún persiste una enorme distancia entre la disponibilidad formal de ciertos recursos y su aplicabilidad efectiva.

Además Argentina es responsable de violar el derecho a la información considerado como un derecho humano de las mujeres. Argentina deberá adaptar su derecho interno de inmediato a los estándares internacionales de derechos humanos de las mujeres y dictar leyes nacionales -con proyección hacia las locales- que prohíba expresamente el acoso sexual laboral y establezca sanciones y el procedimiento a aplicar para solucionar estos padecimientos de la víctima con una visión de género y desde un punto de vista de la víctima razonable dictar sentencias, mejorando en gran medida la capacitación de quienes deben aplicar las leyes, atender a las víctimas, educar a empresarios, trabajadores, maestros, a toda la familia, y debe hacerlo con urgencia, para recuperar el tiempo perdido. 
Consideramos que Argentina ha fracasado en la efectiva implementación y control de dichas normas internacionales de derechos humanos en el tema propuesto. Y a ello se llega por los resultados obtenidos: falta del deber de debida diligencia, sin dudas motivado por un desinterés en el bienestar de la población por parte de la clase política que gobernó en el período de la investigación que no mostró voluntad política direccionada a ese fin supremo del Estado. Esa es la razón del fracaso del derecho internacional de los derechos humanos que en materia de acoso sexual laboral no ha ingresado efectivamente en el plano material de vigencia sociológica de las normas internas y poder asegurar así los derechos de las mujeres, es decir, logramos con esto, nuestro objetivo general. El interés nacional del Estado no fue aplicar dichas garantías.

En tanto que, en lo que hace a nuestro primer objetivo específico, somos conscientes que la normativa en Argentina no ha evolucionado: se introdujo junto a otras figuras por norma internacional pero no hay ley nacional específica sobre el tema como la existente en la Provincia de Buenos Aires, por ejemplo. Sin embargo en otros países latinos como vimos, no en todos, hace décadas existe dicha ley nacional de protección. Y donde no la hay, se aplica para resolver los casos judiciales, la ley de derechos humanos, o civil, o laboral, o social, pero hay denuncias y se investigan y se llega a una solución, es decir, hay cumplimiento efectivo de las garantías constitucionales, a diferencia de Argentina, donde no se registran las denuncias, no se sabe el número de víctimas, no se investiga, no se respetan de este modo los derechos de las mujeres víctimas, etcétera, es decir, hay mayor impunidad de esta manera.

La retórica de la ley parece haber reemplazado el rol de las políticas públicas, necesarias para implementar y sostener con una política de estado los programas que traduzcan en respuestas concretas los derechos reconocidos. Estadísticas claras, precisas, confiables, con información segregada por sexo, ampliamente difundidas y disponibles para la población, son elementos esenciales para el monitoreo y evaluación de impacto de las políticas y programas implementados (segundo y tercer objetivos específicos). Sin embargo, en aspectos claves para monitorear la vigencia y respeto de los derechos de las mujeres en Argentina tales estadísticas no existen, son inadecuadas o incompletas, no existen pues, datos fidedignos para basarnos en obtener un control sobre la aplicación o no de las normativas internacionales en derechos humanos en nuestro tema de estudio. Lógico que en consecuencia, tampoco se puede conocer el estado en que se encuentra nuestro país sobre qué cantidad de denuncias existen en todo el territorio, su trámite, investigación, conclusión, sentencias, etcétera. Por lo que 
debimos valernos de informes emitidos por la OEA, ONU y ONGs de derechos humanos que defienden los derechos de las mujeres (Ej: ELA) y datos de autores que han escrito sobre este particular para ayudarnos a concluir y arribar a nuestra hipótesis. Así concluímos que no existen políticas públicas sobre nuestro tema en particular, más allá de las "buenas intenciones" redactadas en la página oficial del organismo encargado de velar porque se cumplan los Tratados Internacionales de Derechos Humanos respecto de la mujer, el Consejo Nacional de la Mujer, por lo que Argentina no está insertada en la comunidad internacional en el universo de los derechos de ésta índole (segundo objetivo específico), por lo que tampoco se puede medir su impacto (tercer objetivo específico) pero sí concluir que sin políticas públicas no existe voluntad política de que logren tener vigencia las normas internacionales al respecto.

$\mathrm{Y}$ en la postura de los Idealistas, ¿quién debe proveer a satisfacer los derechos humanos? Es el Estado. Incumbe al Gobierno la responsabilidad primordial de cumplir plenamente las obligaciones que el Estado parte ha contraído y especialmente de rendir cuentas al respecto. En Argentina falta una autoridad nacional con suficiente legitimación, jerarquía institucional, recursos económicos y humanos que centralice y articule como una política integral las diversas iniciativas existentes en materia de violencia contra las mujeres, especialmente en el acoso sexual laboral, tanto a nivel nacional como en las jurisdicciones provinciales. 
ANEXO

LEY N ${ }^{\circ}$ 12.764. DOCUMENTAL ORIGINAL.

\section{Mesa de Entradas Legislativa} reporte al 08/03/2001

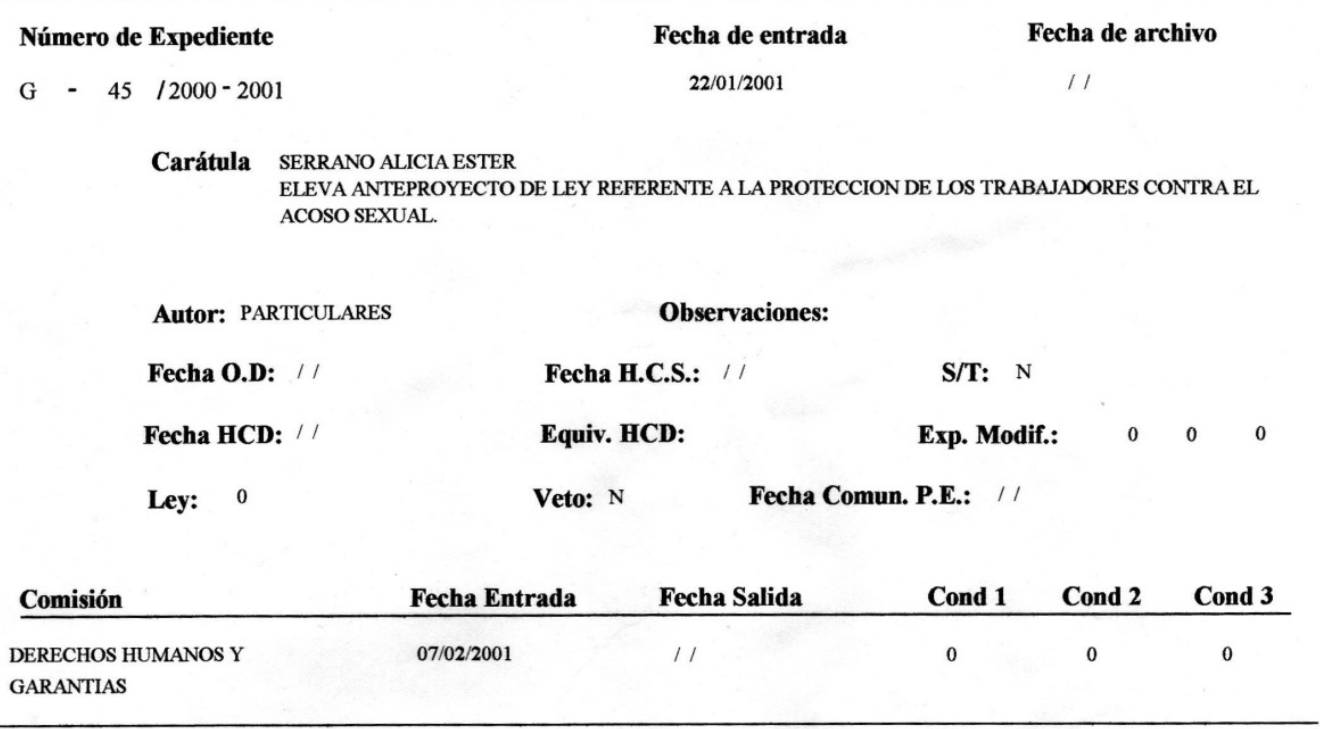




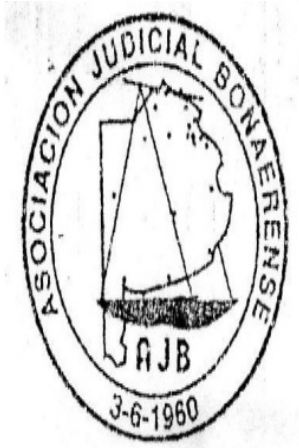

\section{ASOCIACION JUDICIAL BONAERENSE}

PERSONERIA GREMIAL N' 1446 - FEDERACION JUDICIAL ARGENTINA - C.T.A

Sede Comisión Directiva Provincial: 50 No 712 - C.P. 1900 - La Plala - Pcia de Buenos Aires Tel. (02.21) 423-1006 / 422-85594- Fax (0221) 425-0458

E-mail: aib@sallink.com ar

La Plata, 27 de diciembre de 2000

Por la presente quiero expresar todo mi apoyo a la iniciativa legisletiva promovida por la Dra. Alicia E. González Serrano, en la que impulsa "sanciones para cualquier" funcionario o agente público que ejerza la conducta de acoso sexual...".

La Asociación Judicial Bonaerense, se ha caracterizado durante esios iltimos años por sostener consecuentemente los derechos a la igualdad de oportunidades y también por el pleno respeto de las garantias institucionales que resguardan a todas las personas, particularmente a los trabajadores sin diferencia de género.

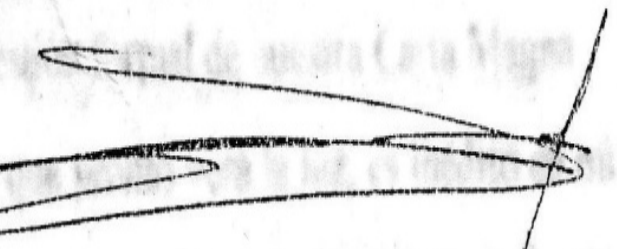


Pravincia de eßruenos etives

Coordinador General

de Contral de Gestión

La Plata, 9 de Enero de 2001.

\section{Señora}

Dra. Alicia Serrano González

$\underline{\mathbf{S}}$

D

De mi mayor consideración:

Tengo el agrado de dirigirme a Ud., a efectos de informarle respecto de su presentación de un proyecto de ley sobre acoso sexual, y adhesiones al mismo de distintas entidades. La citada documentación, de acuerdo con lo informado por personal de la Unidad Gobernador, fue remitida con fecha 18/12/2000 y 9/1/2001, respectivamente, al Ministerio de Justicia, a efectos de darle el tratamiento que corresponda.

Asimismo, cabe consignar, que se ha cumplido con lo conversado en las dos ocasiones que fue recibida por el suscripto, y que en cada oportunidad que lo requirió, el Secretario Privado, Sr. Joaquín Pussino, le ha informado sobre el curso dado a su presentación.

atentamente.

Sin otro particular, me reitero a su disposición, y la saludo

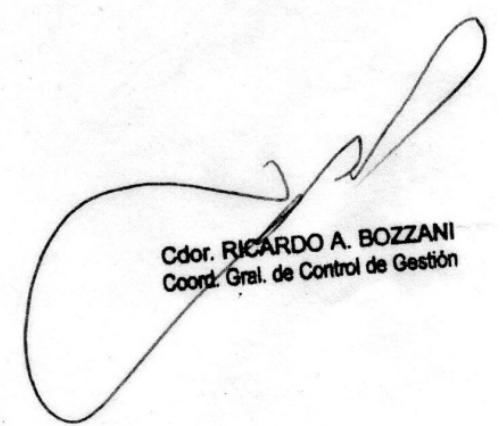


Provincia de eßBuenos etires

Coordinador General

de Contral de Gestion

La Plata, 30 de Marzo de 2001.

\section{Señora}

Dra. Alicia Serrano González

$\underline{\mathbf{S}}$

De mi mayor consideración:

Tengo el agrado de dirigirme a Ud., a efectos de adjuntarle fotocopias de las actuaciones que me hiciera llegar el Dr. Carlos Alberto Valdez, Secretario Relator de la Comisión de Derechos Humanos y Garantías, del Honorable Senado de Buenos Aires, quien a su vez me manifestó, estar a su disposición para lo que estime corresponder. Su teléfono es 422-0081, internos 677/8/9.

Sin otro particular, saludo a Ud. atentamente.

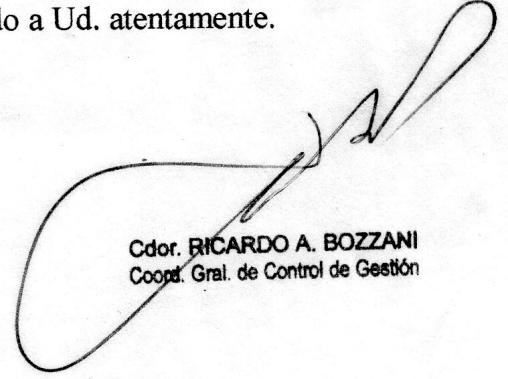


La Plata, 2 de enero de 2000. -

Por la presente expreso todo mi apoyo a la iniciativa legislativa promovida por la doctora

Alicia E. Serrano González, en la que se trata de normativizar sobre

La conducta de acoso sexual de funcionario o agente público.

La Unión de Empleados de Justicia de la Nación ha hecho eco de sus pensamientos desde hace varios años por defender los derechos de la igualdad

de oportunidades y respetando todas las garantías institucionales que poseen

todos los trabajadores sin diferenciar el sexo de cada uno de ellos.-

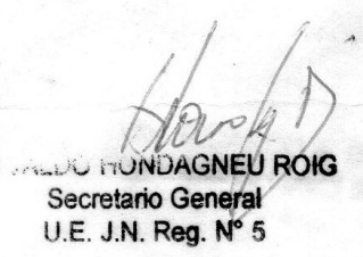




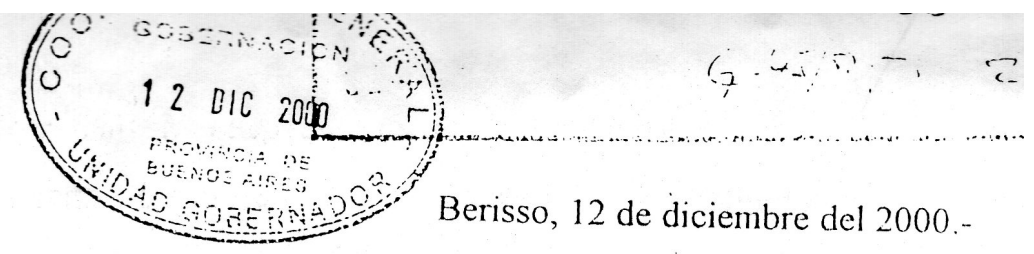

$\mathrm{Al} \mathrm{Sr}$.

Gobernador de la Pcia. de Buenos Aires

Dr. Carlos Ruckauf

SU DESPACHO.-

Ref.: NOTA DE ELEVACIÓN PROYECTO DE LEY.-

Tengo el honor de dirigir el presente Proyecto de Ley a V.E. referido a la prohibición y definición de acoso sexual en el lugar de`trabajo en la administración pública provincial

El mismo consta de trece artículos, y está acompañado de un trabajo sobre el tema que he realizado a los efectos de ilustrar adecuadamente a nuestros legisladores sobre los fundamentos esenciales que hacen necesario que dicho proyecto tome finalmente cuerpo y sea aprobado por todos los representantes de la comunidad en un esfuerzo más por producir la Justicia requerida por los habitantes de esta provincia. anexo la decisión de aquellos ciudadanos que me han acompañado a lo largo de más de tres meses de lucha emprendida por defender los ideales que todos juramos defender pero que actualmente falta que sea llevado a la práctica, y que es defender la Justicia como único norte de nuestros destinos en conciencia y en cuerpo y alma. Esa decisión consta en un total de 27.1 hojas legalizadas debidamente

V.E. el día 31/8/00, de cuyo encuentro el Sr. Gobernador propuso que 


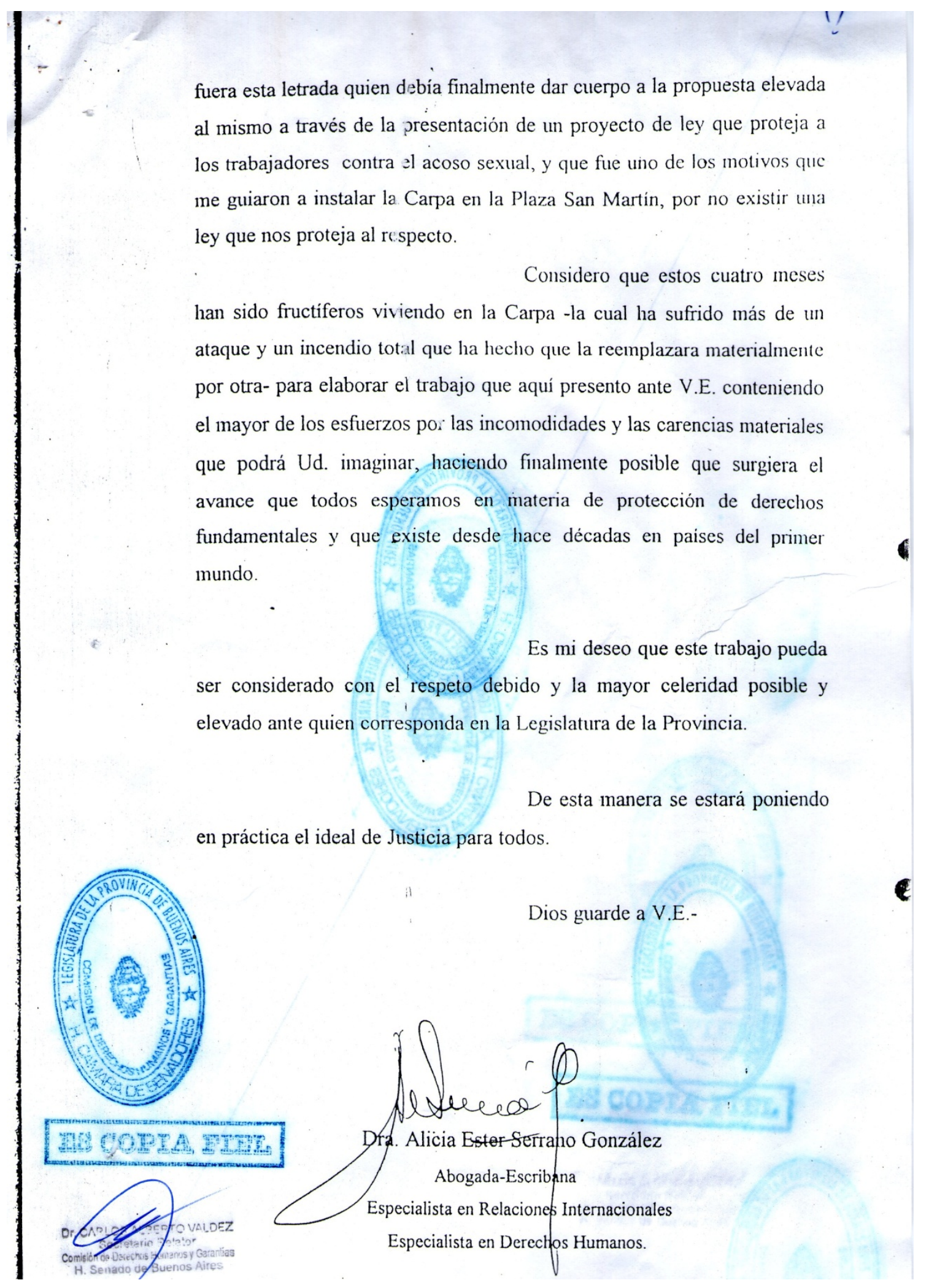


Berisso, 3 de enero del 2001.-

Al Sr.

Gobernador de la Pcia. de Buenos Aires

Dr. Carlos Ruckauf

SU DESPACHO.-

Ref: ELEVACIÓN DE AVALES

AL PROYECTO DE LEY PRESENTADO.-

Tengo el honor de dirrigir la presente a V.E. refericka al acompañamiento de avates que han brindado Asociaciones de trabajadores al Proyecto de Ley presentado por esta letrada al Poder Ejecutivo, cuyo objeto fuera la "prohibición y definición de acoso sexual en el lugar de trabajo en la administración pública provincial".

Como verá V.E., dichas asociaciones poseen una destacada actuación en nuestra comunidad en defensa de los derechos de sus representados, de significativo potencial en el caso por pertenecer a la Administración de Justicia provincial (Asociación Judicial Bonaerense) y nacional (Unión Empleados de la Justicia Nacional), haciendo realidad con dichos avales, el ideal que mantiene quien suscribe, respecto del papel que deben jugar los ciudadanos en la confección de las leyes ejerciendo democráticamente su voluntad, máxime por aquellos ciudadanos que forman parte del Poder Judicial, cuando están en juego altos valores morales como el que protege el proyecto elaborado, cual es la libertad sexual.

196 Reitero que es mi deseo que el trabajo entregado ante V.E. pueda ser considerado con el respeto debido y 
la mayor celeridad posible y elevado ante quien corresponda en la Legislatura de la Provincia.

De esta manera se estará poniendo en práctica el ideal de Justicia para todos.

Dios guarde a V.E.-

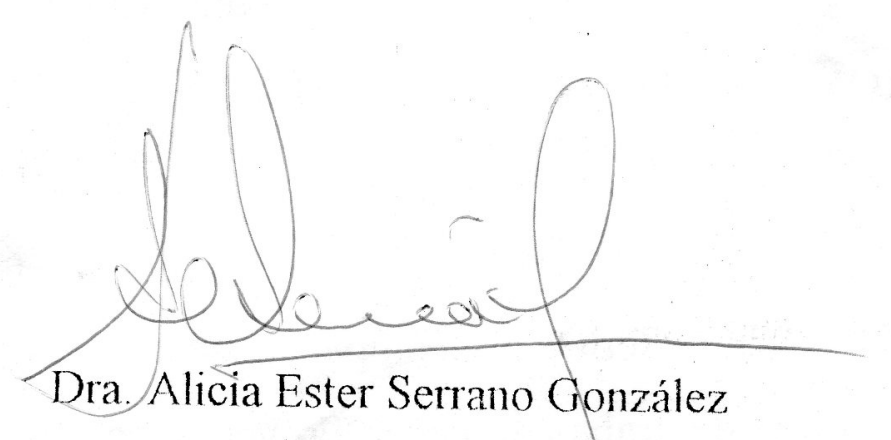

Abogada-Escribana

Especialista en Relaciones Internacionales

Especialista en Derechos Humanos.

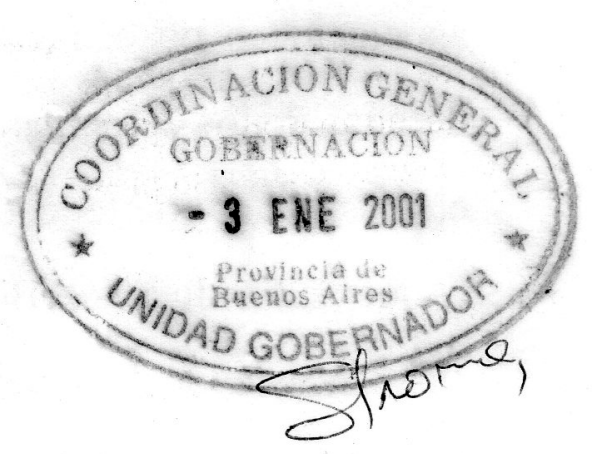




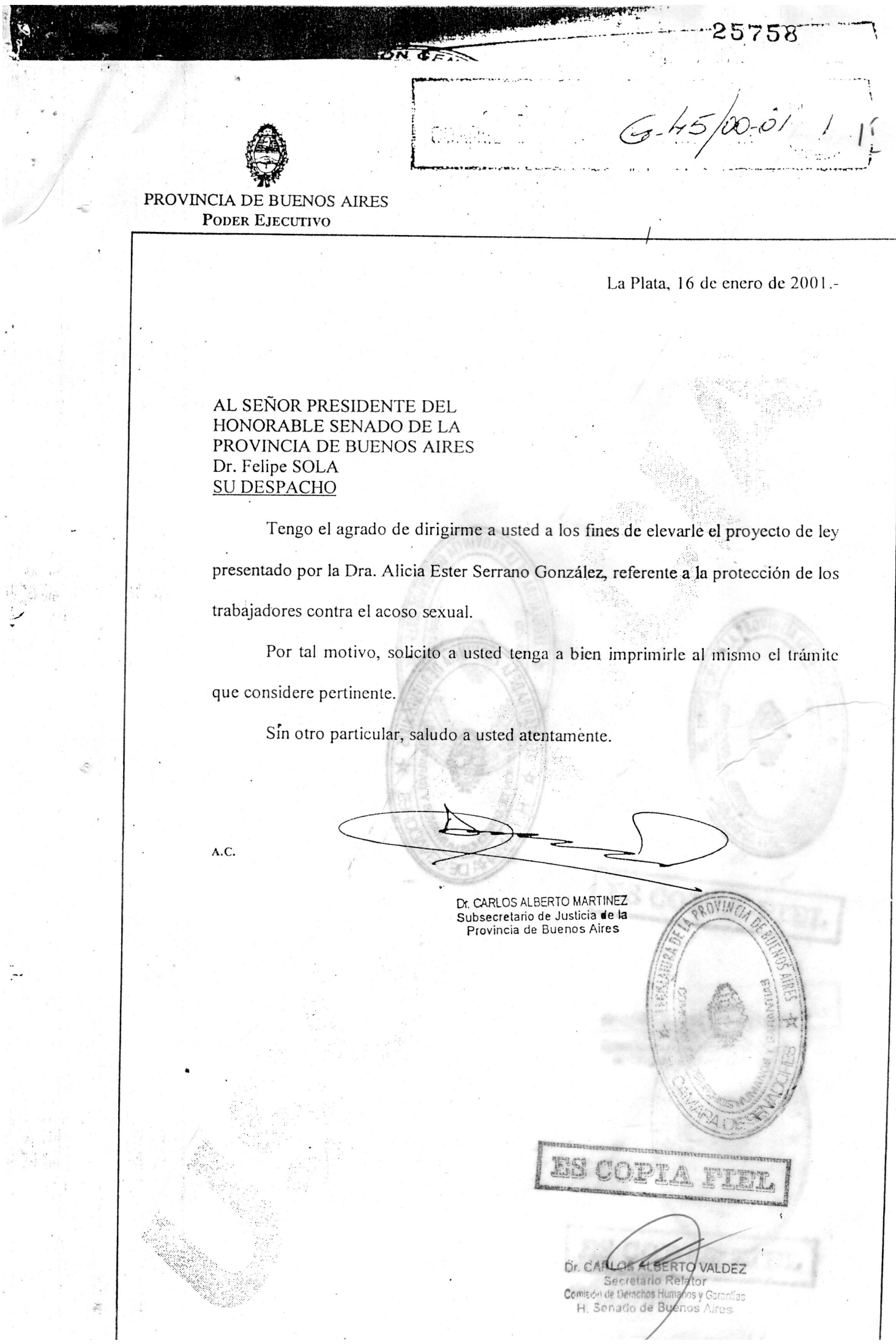


La Dra. Alicia Ester Serrano González, en uso de los derechos que le acuerda el art. $39^{\circ}$ de la C.N., presenta el siguiente proyecto de ley, con el objeto de prohibir y establecer sanciones para cualquier funcionario o agente público que ejerza sobre otro la conducta de acoso sexual en el ámbito de la Administración Pública provincial.

\section{PROYECTO DE LEY:}

El Senado y Cámara de Diputados, etc.

Art. $1^{\circ}$ : Todo funcionario o empleado -en relación de dependencia o por contrato- de la provincia tiene prohibido ejercer sobre otro las conductas que esta Ley tipifica como acoso sexual.

Art. $2^{\circ}$ - Se entiende por acoso sexual el accionar de los funcionarios o empleados públicos que valiéndose de su posición jerárquica o de circunstancias vinculadas con su función, incurran en conductas que tengan por objeto cualquier tipo de acercamiento sexual no deseado hacia la persona a quien va dirigido, requerimiento de favores sexuales y cualquier otra conducta verbal o física de naturaleza sexual, cuando se da una o más de las siguientes circunstancias:

a) Cuando someterse a dicha conducta se convierte de forma implícita o explícita en un término o condición de empleo de una persona.

b) Cuando el sometimiento o rechazo a dicha conducta por parte de la persona se convierte en fundamento para la toma de decisiones en el empleo o respecto del empleo que afectan a esa persona.

c) Cuando esa conducta tiene el efecto o propósito de interferir de manera irrazonable con el desempeño del trabajo de esa persona o cuando crea un ambiente laboral de abuso, intimidante, hostil u ofensivo.

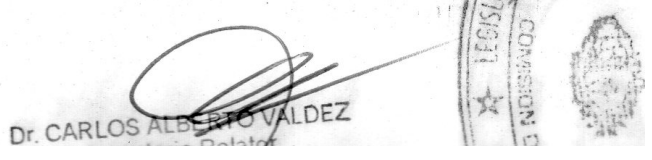


Art. $3^{\circ}$. - La persona acosada de uno u otro sexo podrá presentar la denuncia ante una oficina especial que se creará a estos efectos, a cargo de dos especialistas en el tema acoso sexual, de distintos sexos con el fin de asegurar la atención tanto a hombres como a mujeres, dentro de los organismos correspondientes del lugar de trabajo donde desarrolla su actividad. Dicha denuncia tendrá carácter de confidencial, iniciándose al respecto la correspondiente investigación de forma inmediata, con la declaración de testigos si los hubiera y comenzando a proveerse la totalidad de la prueba ofrecida por el o la denunciante. Todos los pasos de la investigación deben quedar completamente documentados. Asimismo se tomarán las medidas correctivas apropiadas en forma inmediata para hacer cesar el acoso.

Se asegurará al testigo que declare que no serán pasibles de sanciones o perseguidos, no pudiendo ser despedidos sin causa hasta un año después de su referida actuación.

Art. $4^{\circ}$ - En caso de no comprobarse que ha existido la conducta definida como acoso sexual la o el denunciante retendrán la estabilidad en sus cargos dentro del escalafón administrativo.

Art. $5^{\circ}$ - En caso de comprobarse que ha existido la conducta definida como acoso sexual se dispondrá la suspensión o el despido de acuerdo a la gravedad del hecho en forma inmediata, hacia el denunciado cualquiera fuese la categoría en la cual se desempeña.

Art. $6^{\circ}$ - Serán permitidos para la comprobación de la conducta de acoso sexual todos los medios de prueba legislados en los códigos de procedimientos de la provincia de Buenos Aires y su valoración quedará a cargo del especialista designado fundada en los procedimientos y antecedentes internacionales y el estándar para determinar si el acoso es suficiente para provocar la conducta detallada en el art. $2^{\circ}$, será el de víctima razonable. En tanto que para la prueba regirá el régimen de inversión de la carga debiendo probar el acusado o acusada la falsedad de la denuncia y el empleador su eximición de responsabilidad. 
Art. $7^{\circ}$ - La presente será extensiva a todos los funcionarios y empleados públicos de organismos centralizados y descentralizados.

Art. $8^{\circ}$ - A los fines de aplicarse el derecho sustancial, regirán las normas internacionales en la materia especialmente las contenidas en la Convención sobre la eliminación de todas las formas de discriminación contra la mujer o Ley 23.179/85, Convención Interamericana para prevenir, sancionar y erradicar la violencia contra la mujer o Convención de Belem do Pará del 9/6/94, Declaración y Plataforma de Acción de Beijing de 1995 de la Cuarta Conferencia Mundial sobre la Mujer, Tratados de derechos humanos contenidos en el art. 75 inc. 22 de la C.N., Convención sobre la discriminación (empleo y ocupación) $1958 \mathrm{n}^{\circ} 111 \mathrm{de}$ la Organización Internacional del Trabajo (OIT), Recomendación General $\mathrm{n}^{\circ} 19$ de la OEA, y toda otra disposición que establezca mejores derechos que los contenidos en anteriores normas como así también las interpretaciones que al respecto emila la Comisión Interamericana de Mujeres de la OEA, Comité sobre la Eliminación de la Discriminación contra la mujer, Comisión de Derechos Humanos de la OEA, Comisión de Derechos Humanos de la ONU, Comité de Derechos Humanos de la ONU, u otros organismos internacionales de dęrechos humanos.

Art. $9^{\circ}$ - El procedimiento señalado en el art. $3^{\circ}$ es voluntario, sin perjuicio que quien alega ser víctima de acoso sexual pueda denunciar o demandar ante sede judicial sin necesidad de haber agotado primero la vía administrativa para proteger sus derechos.

Art. $10^{\circ}$ - Un Tribunal o Juez de Tribunal Administrativo puede acordar indemnización por daño moral y material sufrido por el acosado o acosada.

Art. $11^{\circ}$ - Se considera causa de discriminación sexual ilegal contra otros individuos si se otorgan oportunidades de empleo o beneficios a cambio de la sumisión de un empleado a las propuestas sexuales o a los pedidos de favores sexuales de un funcionario o empleado, en desmedro oerovin aquellos que cumplian con los requisitos pero se les negó esa oportunidad o beneficio. 
Cualquier persona que se queje de una violación a lo dicho anteriormente, puede presentar una queja como manda el art. $3^{\circ}$.

Art. $12^{\circ}$ - Se asegurará que la información sobre el acoso sexual llegue a todo personal de la Administración Pública a través de carteleras, cursos, conferencias, charlas, etc. ya sea en el lugar de trabajo o en sitios públicos.

Art. $13^{\circ}$.- Comuniquese al Poder Ejecutivo. 


\section{Pravincia de êsuenas eftires}

Coordinador General

de Contral de Gestión

\section{Señora}

\section{Dra. Alicia Serrano González}

$\underline{\mathbf{S}}$

D

La Plata, 24 de Enero de 2001.

De mi mayor consideración:

Tengo el agrado de dirigirme a Ud., a efectos de informarle que con fecha 18/1/2001, el Sr. Subsecretario de Justicia de la Provincia de Buenos Aires, Dr. Carlos Martínez, comunicó a la Coordinación General de la Unidad Gobernador, que el proyecto de Ley que presentara oportunamente, fue elevado al Sr. Presidente delHonorable Senado, Ing. Felipe Solá, con fecha 17 del corriente mes.

Sin otro particular, saludo a Ud. atentamente. 


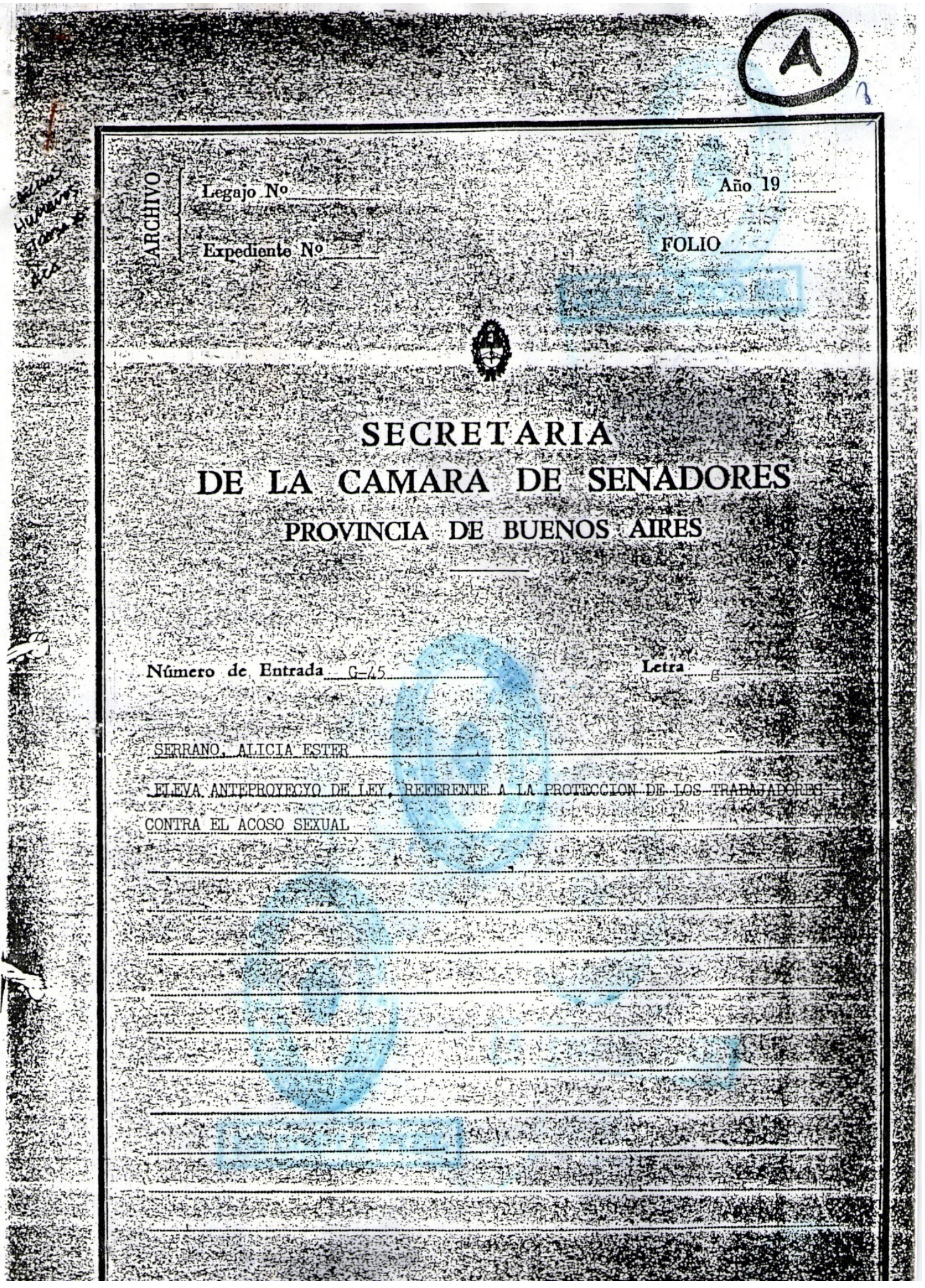


CORRESPONDE EXPTE. G-45/00-01

PROVINCIA DE BUENOS AIRES

H.CAMARA DE SENADORES

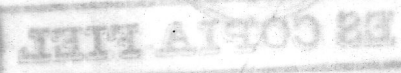

// LA PLATA, 07 de febrero de 2001

Comisiones de:

En Sesión de la fecha el H. Senado lo destina a las

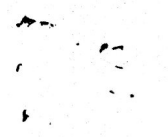

$1^{\circ}$. Derechos Humanos y Garantías
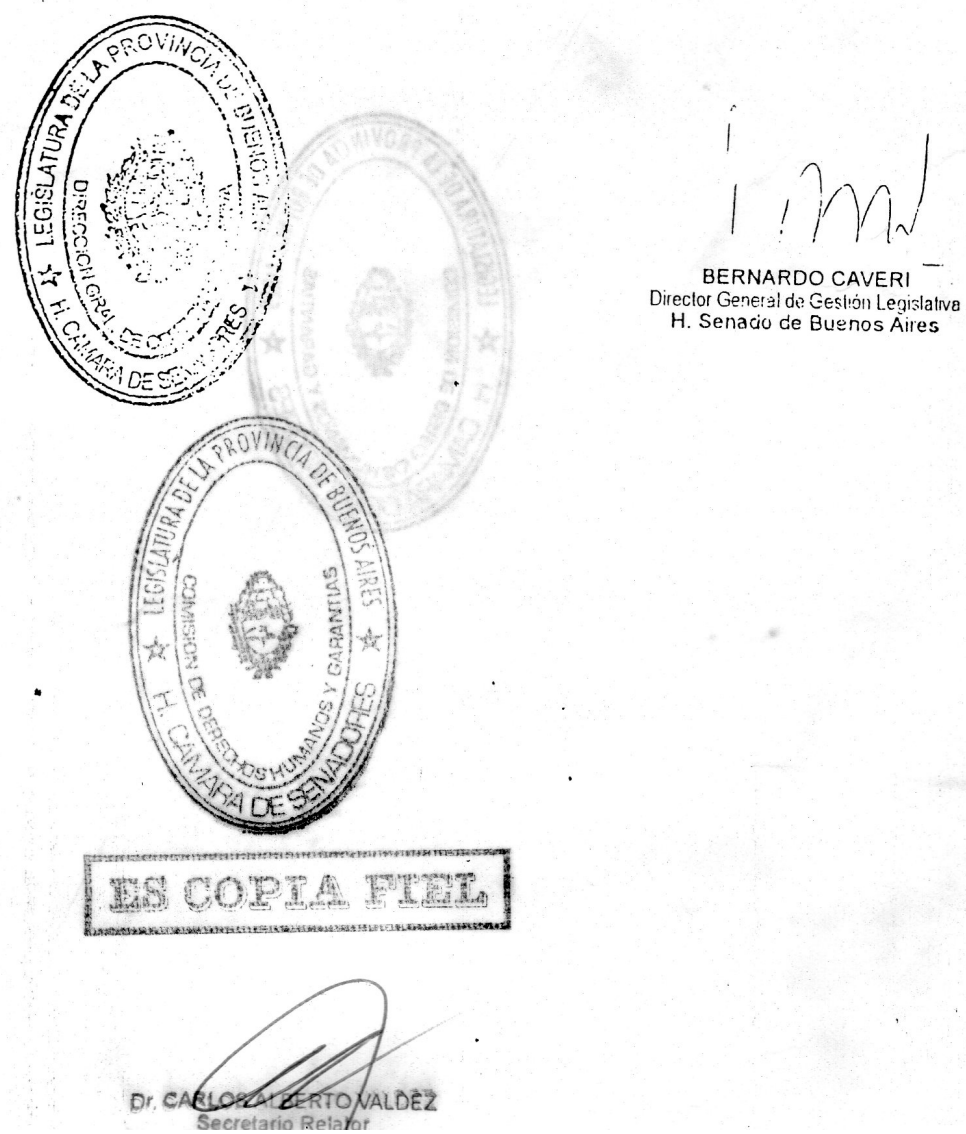

Direclor General de Gestion Legislatve
H. Senacio de Buenos Aires 


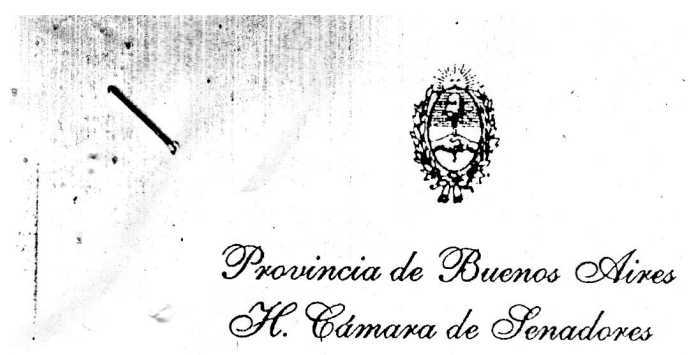

LA PLATA, 28 DE MARKO I)L:2001.-

Al Sr. Coordinador de Control de Gestión

Contador RICARDO BOZZANI

(1900) 6 ENTRE 51 Y 53

LA PLATA

De mi mayor consideración:

Tengo el agrado dirigirme a Ud., a los efectos de ponerlo en conocimiento, y solicitarle que tenga la amabilidad de trasmitirle al Sr. Gobernador Dr. CARLOS FEDERICO RUCKAIF, lo oportunamente resuelto en la Comisión De derechos Humanos y Garantías , en ocasión de tratar el Expediente G-45 Serrano González Alicia Ester sobre : ELEVA ANTEPROYECTO DE LI:Y, REFERENTE A LA PROTECCION DE LOS TRABAJADORES SOBRE ACOSO SEXUAL ( cuya copia se adjunta bajo la letra $\mathbf{A}$ ) .-

De acuerdo a lo manifestado precedentemente, al abordar el expediente de referencia, y en la inteligencia de darle una rápida solución al tema en cuestión, la Comisión a través de sus integrantes consideró oportuno cotejar el Anteproyecto presentado por la Sra.- Serrano con el Proyecto D.82-2000-01 del Diputado FERRARI (cuyo despacho sancionado original se agrega junto con la presente bajo la letra B), que contaba con la sanción de la Cámara de Diputados. Advirtiendo rápidamente que resultaba mas operativo adecuar la media sanción del Proyecto D.82 -2000-01, que presentar un nuevo proyecto de Ley que debería sortear todo el trámite legislativo. 


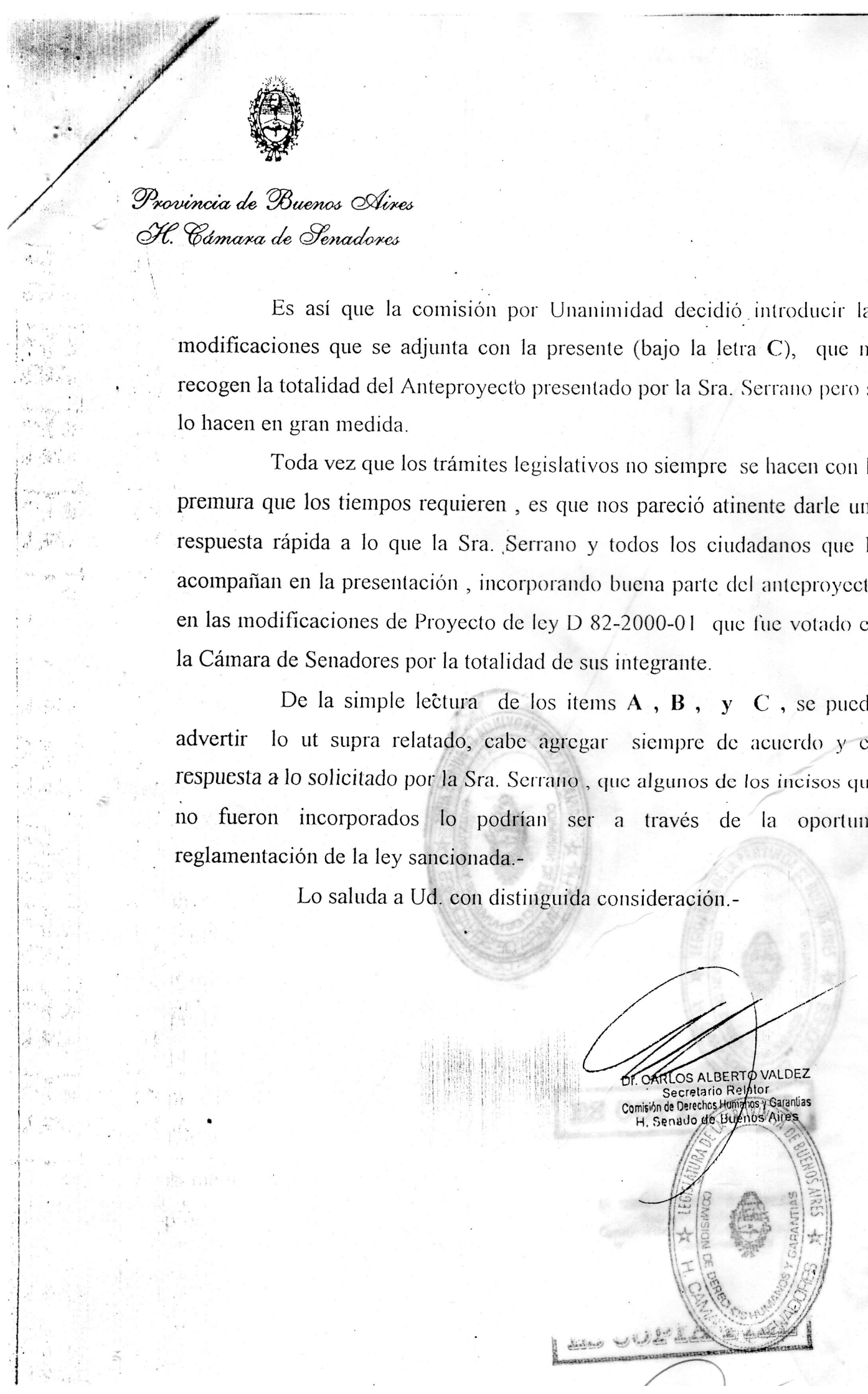


La Dra. Alicia Ester Serrano González, en uso de los derechos que le acuerda el art. $39^{\circ}$ de la C.N., presenta el siguiente proyecto de ley, con el objeto de prohibir y establecer sanciones para cualquier funcionario o agente público que ejerza sobre otro la conducta de acoso sexual en el ámbito de la Administración Pública provincial.

\section{PROYECTO DE LEY:}

El Senado y Cámara de Diputados, etc.

Art. $1^{\circ}$ : Todo funcionario o empleado -en relación de dependencia o por contrato- de la provincia tiene prohibido ejercer sobre otro las conductas que esta Ley tipifica como acoso sexual.

Art. $2^{\circ}$ - Se entiende por acoso sexual el accionar de los funcionarios o empleados públicos que valiéndose de su posición jerárquica o de circunstancias vinculadas con su función, incurran en conductas que tengan por objeto cualquier tipo de acercamiento sexual no deseado hacia la persona a quien va dirigido, requerimiento de favores sexuales $y$ cualquier otra conducta verbal o fisica de naturaleza sexual, cuando se da una o más de las siguientes circunstancias:

a) Cuando someterse a dicha conducta se convierte de forma implícita o explícita en un término o condición de empleo de una persona.

b) Cuando el sometimiento o rechazo a dicha conducta por parte de la persona se convierte en fundamento para la toma de decisiones en el empleo o respecto del empleo que afectan a esa persona.

c) Cuando esa conducta tiene el efecto o propósito de interferir de manera irrazonable con el desempeño del trabajo de esa persona o cuando crea un ambiente laboral de abuso, intimidante, hostil u ofensivo.

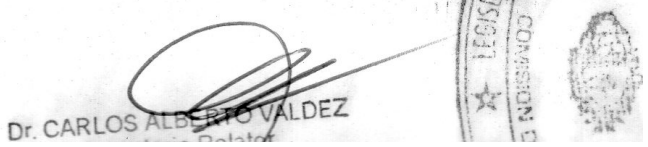




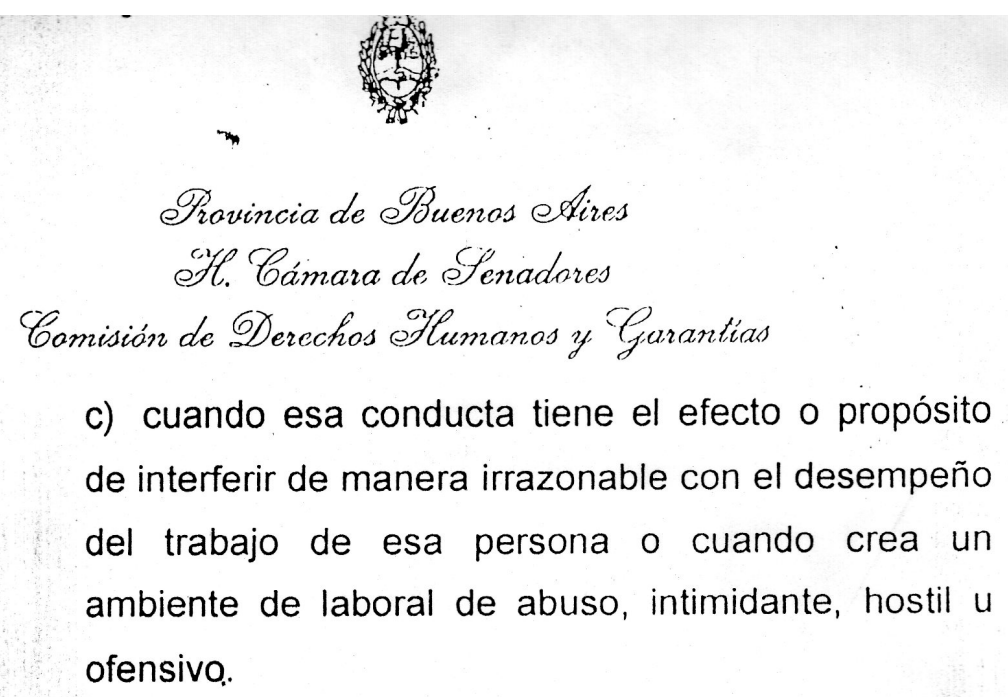

ARTICULO $3^{\circ}$. El incumplimiento de la prohibición establecida en el articulo $1^{\circ}$ de esta Ley, será causal de una sanción de orden correctivo, que podrá implicar apercibimiento o suspensión de hasta 60 días corridos. Salvo que por su magnitud y gravedad pueda encuadrarse en la figuras de cesantia, exoneración o ser considerado falta grave, según el régimen disciplinario de que se trate.

En la instrucción del sumario respectivo se deberá garantizar el carácter confidencial de la denuncia.

ARTICULO $4^{\circ}$. Comuníquese al Poder Ejecutivo.

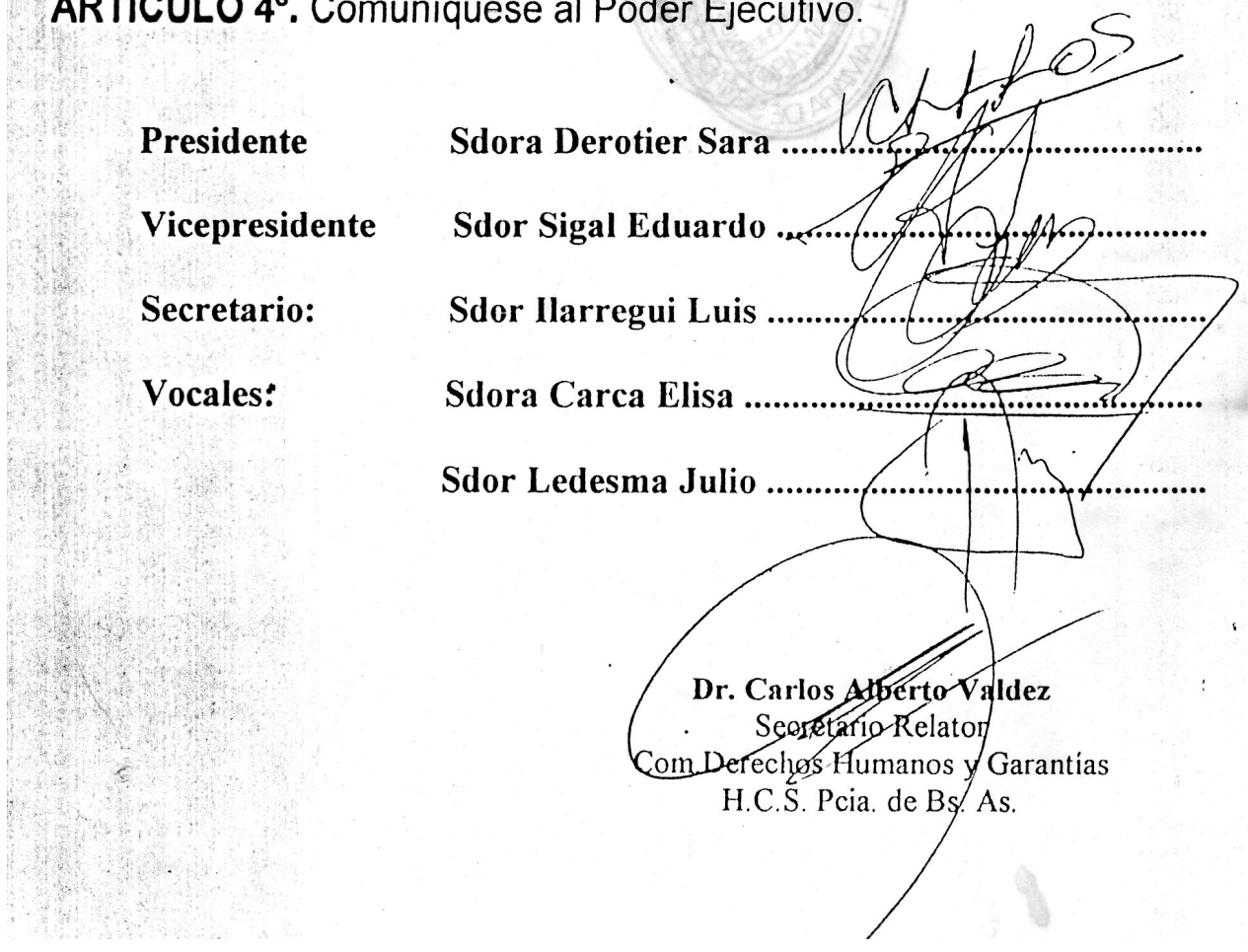


Los jueces bonaerenses polemizaron ayer duramente con el gobernador Carlos Ruckauf a raíz de una iniciativa defendida por el mandatario acerca de que los magistrados puedan ser removidos a través del voto popular.

La propuesta, esbozada el jueves último por Ruckauf, de que los jueces bonaerenses puedan ser removidos a través de voto popular y no por decisión de sus pares, encendió duras réplicas por parte de los magistrados de la Provincia, quienes adjudicaron intereses políticos a la iniciativa.

"Debe llegar, tarde o temprano, el sistema en el que el voto popular produzca la remoción de jueces y fiscales que, por actitudes excesivamente garantistas, ponen en peligro la vida de los habitantes decentes y dejan en libertad a quienes deberían estar separados de la sociedad", opinó Ruckauf.

\section{Insistió con iniciativa}

El gobernador insistió ayer con su iniciativa y se preguntó "por qué razón un juez o fiscal que deja salir asesinos y violadores tiene que tener solamente un juicio de sus pares", y argumentó que su propuesta evitaría que los jury se conviertan "en lugares de debate político".

Ayer, el Colegio de Magistrados y Funcionarios del Poder Judicial de la Provincia repudió el proyecto del gobernador y sostuvo que con esa idea el mandatario pretende ganar "votos" y atribuir a la Justici la responsabilidad de la política de seguridad, potestad del Ejecutivo.

Además, tos magistrados manifestaro su "estupor" y advirtieron que Ruckauf durante su desempeño en el gobierno nacional- "fue un calificado protagonista en el proceso de sanción de la ley dos por uno y de la ley nacional que estableció la libertad anticipada de los condenados por libertad anticipadas graves".

Este nuevo cuestionamiento del Ejecu-

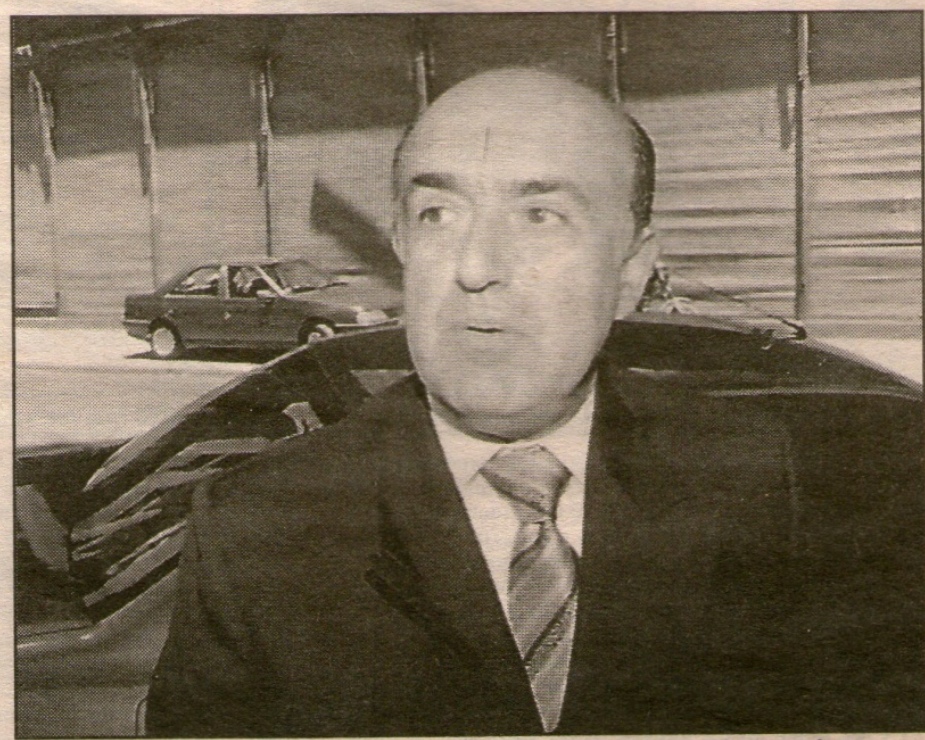

\section{Polémica tras afirmar Ruckauf que quería remover jueces por voto popular.}

también que los 2.700 magistrados y funcionarios judiciales de la Provincia de Buenos Aires resolvieran renunciar a integrar la Comisión de Mapa Judicial de ese distrito. que depende del Ministerio de Justicia provincial.

"La introducción de la nemoción de magistrados por el voto popular pareciem dirigida preci conente dirigida precisamente a la obtención de esos mismos votos", preciso el Colegio an una nota firmada por su presidente, Carlos Pagliere, quien expresó a Télam su creencia de que para el gobernador "es una forma fácil de poner el enfoque de inseguridad en quien no tiene a cargo ese problema".

Los magistrados hicieron público sn "unánime rechazo a la injusta imputación de atribuirles la defensa de los delincuentes", y advirtieron que el dictado de leyes "no es potestad del Poder Judicial, quien sólo es su ejecutor".

En sus cuestionamientos al desempeño de los jueces, Ruckauf lamentó que los jury de enjuicianicus sén lugares de discusión política, y consideró que, en esos ámbitos, "un señor que comete un delito no puede ser juzgado por el parido al que pertenece".

"(Ese hombre) tiene que ser juzgado por la gente porque es un delincuente", sentenció el mandatario, durante una conferencia de prensa en la Casa de Gobierno bonaerense.

\section{Proponen cárcel de por vida para violadores asesinos}

El gobernador bonaerense, Carlos Ruckauf, propuso ayer que los violadores asesinos, especialmente aquellos cuyas víctimas sean menores de edad, cumplan condena de prisión efectiva de por vida. Además, Ruckauf reiteró su propuesta de debatir la posibilidad de eliminar el sistema de inamovilidad de los jueces para que éstos puedan ser removidos por el voto popular.

"Quiero la derogación total del beneficio del dos por uno pero con eso no me alcanza, quiero cárcel de por vida, quiero modificar el sistema de la Argentina porque nunca debe salir en libertad al cure mató v vinó a un mencr" diin el mandatario en con- tiene que terminar con los delincuentes en la cárcel de por vida. no tiene que haber excarcelaciones, ni penas a 15 ni a 20 años". "El que viola a una nena y la mata se tiene que quedar en la cárcel hasta el último dia de su vida, no puede haber un gobernador, como el (ex) gobemador (de Chubut, Carlos) Maestro que lo libere", dijo en alusión al acusado de haber matado a Jenifer Soledad Falcón, de 7 años, en Olavarria.

Respecto de su idea de eliminar la inamovilidad de los jueces para que éstos puedan ser removidos por el voto popular Ruckauf se preountó "por qué razón un juez o fiscal que deja 


\section{BIBLIOGRAFÍA:}

1) Aeberhard-Hodges, Jane.(1996). "Jurisprudencia reciente sobre el acoso sexual en el trabajo". Revista Internacional del Trabajo, vol. 115 (núm. 5), pág. 543-579.

2) Abajo Olivares, Francisco J. "Proyecto de ley de prevención y sanción de la Violencia Laboral y el Acoso Sexual Laboral, dictamen aprobado por las comisiones ...", Buenos Aires, 2012. Revista de Derecho Laboral Doctrina.

3) Albanese, Susana. "Reflexiones desde el Sur-Las opiniones consultivas en la estructura del control de convencionalidad", Presidencia de la Nación, Ministerio de Justicia y Derechos Humanos, Buenos Aires, 2012, pág. 19-60.

4) Alvarez Chavez, Víctor Hugo. Mobbing, estrés y acoso en el ámbito del trabajo: manual teórico-práctico de actuación profesional. Buenos Aires, Ed. García Alonso, 2009, $215 \mathrm{p}$.

5) Argentina - Examen Periódico Universal (EPU) Consejo de Derechos Humanos Primera sesión de EPU - 7/ 18 de abril de 2008-ELA - Equipo Latinoamericano de Justicia y Genero (“ELA”).

6) Argentina - Examen Periódico Universal (EPU) -Consejo de Derechos Humanos -Sesión $14^{\circ}$ de EPU - 22 octubre $/ 5$ noviembre 2012. Informe elaborado por ELA- Equipo Latinoamericano de Justicia y Género.

7) Barbado, Patricia Bibiana. "Los rasgos comunes que presentan el acoso sexual y el acoso psicológico". Jurisprudencia Argentina, Vol. 2 (2007), pág. 123-130.

8) Barreyro, Melisa Andrea, "Acoso sexual. La violencia silenciosa" Revista de Derecho UNS, ISSN 2314-0747, Año 2, Número 2, 2013, pág. 135-144.

9) Bidart Campos, Germán J. (1991). “Teoría general de los Derechos Humanos". Buenos Aires. Ed. Astrea.

10) Cámara Civil y Comercial de Lomas de Zamora, Sala I, 19/11/2002, fallo "M.L.B. c/ Isa, Juan y otro".

11) Carcavallo, Esteban. "Acoso psicológico y sexual como manifestaciones de la violencia laboral". Derecho del Trabajo La Ley, Año 70, n³ 3, Marzo 2010, pág. 506.

12) Carcavallo, Esteban. Acoso sexual. Derecho del Trabajo La Ley, Año 70, nº 7, Julio 2010, pág. 1725.

13) Carreras, Eduardo y Tazza, Alejandro "El Delito de Acoso Sexual: el proyecto legislativo argentino", Doctrina, pág. 50-57, Buenos Aires, 2006. 
14) Caso "Marshall v. Southampton and South-West Hampshire Area Health Authority,Equal Opportunities Review” (Londres), núm. 51, septiembre y octubre de 1993, págs. 51-55.

15) Caso "Sendoya Josefina c. Travel Club SA" -DT- Año LXV №5 Mayo 2001, Buenos Aires: La Ley.

16) $\mathrm{CIDH}$, Acceso a la información en materia reproductiva desde una perspectiva de derechos humanos, 22 de noviembre de 2011, párr. 25.

17) $\mathrm{CIDH}$, Acceso a la justicia para mujeres víctimas de violencia en las Américas, 20 de enero de 2007, párr. 42, párr. 44, párr. 231, párr. 239 y punto I.B. 32.

18) $\mathrm{CIDH}$, Comunicado de prensa 9/13: La CIDH concluye su visita de trabajo a Suriname, 12 de febrero de 2013.

19) CIDH, Informe Actualizado sobre la Labor de la Relatoría sobre los Derechos de la Mujer, OEA, 16 de abril de 2002, párr. 42 y 43.

20) $\mathrm{CIDH}, \mathrm{El}$ derecho de acceso a la información en el marco jurídico interamericano, Segunda Edición, Relatoría Especial para la Libertad de Expresión, 7 de marzo de 2011, párr. 32, 35 y párr.. 36 .

21) Comité CEDAW, Observación General $N^{0} 19$, adoptada por el Comité para la Eliminación de la Discriminación contra la Mujer, $11^{\circ}$ período de sesiones, 1992, U.N. Doc. HRI $\backslash G E N \backslash 1 \backslash R$ ev.1 at 84 (1994).

22) Comité para la Eliminación de la Discriminación contra la Mujer, Opinión sobre la Comunicación No. 6/2005, Fatma Yildrim c. Austria, 21 de julio de 2004, párr. 12.1.1; y Opinión sobre la Comunicación No. 2/2003, A.T. c. Hungría, 26 de enero de 2003, párr. 9.2.

23) Conforti, Benedetto. "Derecho Internacional”. Zavalia Editor. 1995, Argentina.

24) Consejo Nacional de la Mujer, Poder Ejecutivo Nacional, Argentina 2012.

25) Corte Europea de Derechos Humanos, Caso de Opuz c. Turquía, Aplicación No. 33401/02, 9 de junio de 2009, párr. 246.

26) Convención sobre la Eliminación de todas las formas de discriminación contra la mujer, Asamblea general de la UN del 18-12-1970. Ley 23.179.

27) Corte IDH: Caso “Juan Humberto Sánchez”, sentencia del 7 de junio de 2003, párr. 134; y caso “Trujillo Oroza. Reparaciones”, sentencia del 27 de febrero de 2002, párrs. 99-101; entre otros. Corte IDH, Caso de la "Panel Blanca (Paniagua Morales y otros), 
párr. 76, nota 190. Corte IDH, Caso "Radilla Pacheco", sentencia del 23 de noviembre de 2009, párr. 216; Caso Kawas Fernández Vs. Honduras,Fondo, Reparaciones y Costas, sentencia del 3 de abril de 2009. Serie C No. 196, párr. 78. Corte IDH, Caso Heliodoro Portugal Vs. Panamá, Excepciones Preliminares, Fondo, Reparaciones y Costas, sentencia del 12 de agosto de 2008, párr. 144. Corte IDH. Caso Anzualdo Castro Vs. Perú, sentencia del 22 de Septiembre de 2009 párr. 135. Corte IDH. Caso de la Comunidad Moiwana Vs. Suriname, sentencia del 15 de junio de 2005, párr. 156” o también, "Corte IDH. Caso García Prieto y otros Vs. El Salvador, párr. 115. Corte IDH. Caso Anzualdo Castro Vs. Perú, Excepción Preliminar, Fondo, Reparaciones y Costas, sentencia del 22 de septiembre 2009. Serie C No. 202, párr. 119; Corte IDH. Caso Gomes Lund y otros ("Guerrilha do Araguaia") Vs. Brasil. Excepciones Preliminares, Fondo, Reparaciones y Costas, Sentencia de 24 de noviembre de 2010, Serie C No. 219, párr. 211.

28) CNAT, Sala VI- Sentencia Definitiva No 53.965-EXPTE. No8060/96-JUZGADO No 45-AUTOS:"D.J.M, C/S. Y C S.R.L. S/DESPIDO". ... -. SALA VI Sentencia Definitiva No 53.965-EXPTE. Nº060/96-JUZGADO No 45-AUTOS:"D.J.M, C/S. Y C S.R.L. S/DESPIDO"-Buenos Aires, 15 de marzo de 2001.

29) de Vega Ruiz, José Augusto (1991). "El Acoso Sexual como delito autónomo", España, Ed. Colex.

30) Declaración sobre la eliminación de la violencia contra la mujer, ONU, 20 de diciembre de 1993.

31) Di Corleto, Julieta. "La sanción del acoso sexual en el ámbito universitario".

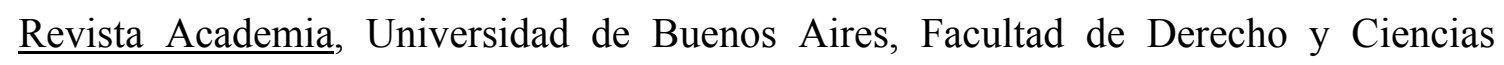
Sociales, año $3 n^{\circ}$ 6, 2005, pág. 339-342.

32) Díaz, Viviana Laura. "Violencia laboral: de lo conceptual a lo específico" (2008).

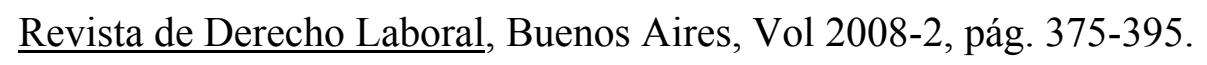

33) Dobarro, Viviana Mariel. "La violencia en las relaciones laborales y el avasallamiento de la dignidad humana. Primera y segunda partes" (2008). Doctrina Laboral y Previsional, año 22, págs.. 763-782 y 892-914.

34) Dougherty, James y Robert Pfaltzgraff, “Contending Theories of International Relations", Harper \& Row Publishers, New York, 1981, p. p. 84-86.

35) Escudero, Ricardo. 1993. "El acoso sexual en el trabajo", Relaciones laborales (Madrid), vol. 9, núm. 24 (23 de diciembre), págs. 28-39. 
36) Fapiano, Oscar Luján. "La eficacia de las Decisiones de los Organismos Internacionales de Derechos Humanos y su Ejecución Interna", Subsecretaría de Derechos Humanos y Sociales, Ministerio del Interior. "Protección Internacional de Derechos Humanos”, pág. 71, Buenos Aires, 1999.

37) Frank, Jorge Leonardo. (2006, Noviembre). "Legislación sobre Acoso sexual". Diario Legítima Defensa, Edición n ${ }^{\circ} 100$.

38) Gebruers, Cecilia. (2012). "Acoso sexual en espacios educativos en Argentina. Una aproximación a su regulación y abordaje a partir de la revisión de decisiones judiciales", Argentina. Ed. ELA.

39) Giuntoli, María Cristina "Mobbing y otras violencias en el ámbito laboral: leyes provinciales y proyectos de ley nacional”, Buenos Aires, El Derecho, 2007, 222 p.

40) González, Elpidio (1996).“Acoso Sexual”. Buenos Aires, Ed. Depalma.

41) Gros Espiell, Héctor. "La eficacia de las Decisiones de los Organismos Internacionales de Derechos Humanos y la Ejecución Interna de Sentencias Internacionales", Subsecretaría de Derechos Humanos y Sociales, Ministerio del Interior. "Protección Internacional de Derechos Humanos", pág. 43, Buenos Aires, 1999.

42) Guerrero, Elizabeth. Violencia contra las Mujeres en América Latina y el Caribe: Balance de una Década 1990-2000, Isis Internacional, Santiago, Chile, Abril 2002, pág. 21. Capítulo 2 Estándares sobre el derecho al acceso a la información pública en materia de violencia y discriminación contra las mujeres, Comisión Interamericana de Derechos Humanos.

43) Husbands, Robert. "Análisis internacional de las leyes que sancionan el acoso sexual". Revista Internacional del Trabajo, Vol.112, n.1.

44) Informe Alternativo para el Comité de Derechos Económicos, Sociales y Culturales $46^{\circ}$ PERÍODO DE SESIONES / EVALUACIÓN SOBRE ARGENTINA. Tercer informe periódico presentado por Argentina sobre la vigencia del Pacto Internacional de Derechos Económicos, Sociales y Culturales.

45) Informes de la Comisión Nacional de la Mujer, elevado para su aprobación ante el Comité de Expertas de Violencia de la Organización de Estados Americanos, del año 2000-2001:V INFORME DE LA REPÚBLICA ARGENTINA PERÍODO: desde el 4 
de febrero de 2000 hasta el 27 de diciembre de 2001-QUINTO INFORME DE LA REPÚBLICA ARGENTINA.

46) Informe de la Comisión Nacional de la Mujer, elevado para su aprobación ante el Comité de Expertas de Violencia de la Organización de Estados Americanos, del año 2005:a) De la "Evaluación de la Implementación de las Disposiciones de la Convención de Belem Do Pará (2006) COMITÉ DE EXPERTAS/OS VIOLENCIA (CEVI) OEA/Ser.L/II.7.10 MECANISMO DE SEGUIMIENTO MESECVI/CEVI/doc.5/05 rev.1 CONVENCIÓN BELÉM DO PARÁ (MESECVI) 24 agosto 2005, 22-24 agosto 2005.

47) Informe del año 2015 de la CIDH de la OEA sobre "Acceso a la información, violencia contra las mujeres y la administración de justicia en las Américas".

48) Jiménez de Aréchaga, Eduardo. El Derecho Internacional Contemporáneo. Ed. Tecnos, Madrid, 1980.

49) Knavs, Verónica. “Acoso moral y sexual en el derecho del trabajo”. Revista Jurídica Argentina La Ley, Vol B (2006), Buenos Aires, pág. 985.

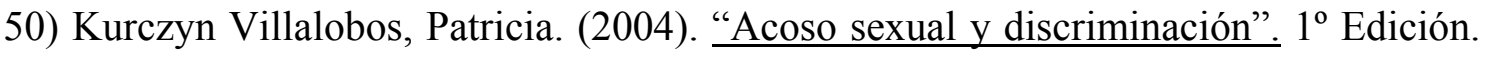
México. Universidad Nacional Autónoma de México.

51) Lerner, Natan. En defensa de los Derechos Humanos, Ed. Delegación de Asociaciones Israelitas Argentinas (D.A.I.A), Buenos Aires, 1958.

52) Lipovetzky, Jaime César y Lipovetzky, Daniel Andrés. “El Derecho del Trabajo en los tiempos del ALCA”, Ed. Distal S.R.L., Buenos Aires, 2002.

53) Lipovetzky, Jaime César y Lipovetzky, Daniel Andrés. "De cómo aprendieron a amar la deuda", Ed. Distal S.R.L., Buenos Aires, 1987

54) Literio, Liliana Hebe. "Trabajo de mujeres: nueva ley de protección integral". Derecho del Trabajo La Ley, Año 69, no 11 (Noviembre 2009), pág. 11-19.

55) Mansueti, Hugo Roberto. “Acoso sexual en las relaciones laborales”. En: Trabajo y seguridad social. Buenos Aires no 1 (ene. 2003) p. [8]-27.

56) Manzur,María Inés. "Violencia laboral y protección de género: segunda parte". Doctrina Laboral y Previsional, año 27, Vol 25 nº 313 (septiembre 2011), pág. 977-986.

57) Marqués, Glauco C. "Responsabilidad del empleador por el acoso sexual y psicológico de los trabajadores”. (2008). Revista Jurídica Argentina La Ley, Vol. E, Buenos Aires, pág. 239-242.

58) Martínez Vivot, Julio J. (1995). “Acoso Sexual en las relaciones laborales. Elementos tipificantes. Clases de acoso. Consecuencias para la empresa, la víctima y el 
acosador. Sujetos activo y pasivo. Procedimiento. Prueba. Normativa aplicable. Jurisprudencia”. Buenos Aires, Ed. Astrea.

59) Medina, Graciela. (1995). “Acoso sexual laboral”. Jurisprudencia Argentina, Id Infojus: DACA950129.

60) Memoria de actividades realizadas - 2009-Introducción. 2007-Resolución MTEySS $\mathrm{N}^{\circ}$ 05/07 Oficina de Asesoramiento sobre Violencia Laboral (OAVL).

61) Mendez, Juan. "La óptica internacional respecto a los Casos Argentinos en el Sistema Interamericano", Subsecretaría de Derechos Humanos y Sociales, Ministerio del Interior. "Protección Internacional de Derechos Humanos", pág. 87, Buenos Aires, 1999.

62) Méndez, Juan E. (1997). "Responsabilidad por los abusos del pasado". Revista de Relaciones Internacionales, $\mathrm{n}^{\circ} 13$.

63) Montoya, Mario Daniel. "El acoso sexual en la sociedad norteamericana". LL 1992D-1264.11

64) Morgenthau, Hans, "Política entre las naciones: La lucha por el poder y la paz", Grupo Editor Latinoamericano, Buenos Aires, 1986, p. p. 12-26.

65) Naciones Unidas, Comité para la Eliminación de la Discriminación contra la Mujer: Recomendación General $N^{\circ}$ 28: las obligaciones fundamentales de los Estados partes bajo el artículo 2 de la Convención sobre la eliminación de todas las formas de discriminación contra la mujer, 16 de diciembre de 2010, U.N.Doc CEDAW/C/GC/28, párr. 27; Recomendación General 19, La violencia contra la mujer, ONU Doc. HRI/GEN/1//Rev.1 (1994), párr. 11.

66) Naciones Unidas, Declaración sobre la eliminación de la violencia contra la mujer, Resolución de la Asamblea General 48/104, 20 de diciembre de 1993, A/RES/48/104, 23 de febrero de 1994.

67) Naciones Unidas, Informe del Grupo de Trabajo sobre la cuestión de la discriminación contra la mujer en la legislación y en la práctica, 19 de abril de 2013, U.N. Doc. A/HRC/23/50, párr. 97(g).

68) Naciones Unidas, Informe del Secretario General, Estudio a fondo sobre todas las formas de violencia contra la mujer, 6 de julio de 2006, U.N. Doc. A/61/122/Add.1, párr. 209, Acceso a la información, violencia contra las mujeres y administración de justicia en las Américas, Organización de los Estados Americanos. 
69) Naciones Unidas, Intensificación de los esfuerzos para eliminar todas las formas de violencia contra la mujer. Informe del Secretario General, 1 de agosto de 2012, U.N. Doc. A/67/220, párr. 77-78. Capítulo 2 Estándares sobre el derecho al acceso a la información pública.

70) Naciones Unidas, Resolución 23/7 del Consejo de Derechos Humanos: Eliminación de la discriminación contra la mujer, 20 de junio de 2013, U.N. Doc. A/HRC/RES/23/7, párr. 12.

71) Naciones Unidas, Resolución 26/15 del Consejo de Derechos Humanos: Acelerar los esfuerzos para eliminar todas las formas de violencia contra la mujer: la violencia contra la mujer como obstáculo para el empoderamiento político y económico de la mujer, 11 de julio de 2014, U.N. Doc. A/HRC/RES/26/15, párr. 7.

72) Observaciones de la CEDAW 2010: Observaciones finales del Comité para la Eliminación de la Discriminación contra la Mujer Argentina. El Comité examinó el sexto informe periódico de la Argentina (CEDAW/C/ARG/6) en sus sesiones $926^{\mathrm{a}}$ y $927^{\mathrm{a}}$, celebradas el 13 de julio de 2010 . La lista de cuestiones y preguntas figura en el documento CEDAW/C/ARG/Q/6, y las respuestas de la Argentina en el documento CEDAW/C/ARG/Q/6/Add.1.

73) OEA, CIDH, Acceso a la información, violencia contra las mujeres y administración de justicia en las Américas, Informes años 2007, 2011 y 2015.

74) Picón, Liliana Noemí. "La equidad de género en el ámbito laboral. Desarrollo cultural y vías operativas para lograrla”. Revista de Derecho Laboral, Vol 2009-1, 2009, Buenos Aires, pág. 333-376.

75) ONU, Informe de la Relatoría Especial sobre la violencia contra la mujer, con inclusión de sus causas y consecuencias. La norma de la debida diligencia como instrumento para la eliminación de la violencia contra la mujer, Comisión de Derechos Humanos, 62 ${ }^{\circ}$ periodo de sesiones, E/CN.4/2006/61, 20 de enero de 2006, párr. 29.

76) Pose, Carlos. 1995. «El acoso sexual en las relaciones laborales», Derecho del trabajo (Buenos Aires), vol. 55, núm. 3 (marzo), págs. 371-374.

77) Pose, Carlos. 2006. «Sobre la futura tipificación del acoso sexual como delito penal», Derecho del trabajo La Ley (Buenos Aires), vol. B, año 66, págs. 1125-1129.

78) Quiroga Lavié, Humberto (1995). "Los Derechos Humanos y su defensa ante la Justicia”. Colombia, Ed. Temis S.A.

79) Recomendación General núm. 19 sobre la violencia contra la mujer (Naciones Unidas: Informe del Comité para la Eliminación de la Discriminación contra la Mujer, 
$11^{\circ}$ período de sesiones, Asamblea General, Documentos Oficiales, cuadragésimo séptimo período de sesiones, Suplemento núm. 38, A/47/38 (Nueva York, 1992), págs. $1-6)$.

80) Recomendaciones de CEDAW para la República Argentina. Exámen de los informes de los Estados Parte-IV y V Informes Periódicos 23 de agosto de 2002-Comité para la Eliminación de la Discriminación contra la Mujer-Período Extraordinario de Sesiones 5-23 agosto 2002.

81) Recomendaciones de la CEDAW. Recomendaciones del Comité para la Eliminación de la Discriminación contra la Mujer (CEDAW) en ocasión de la presentación del Informe de Seguimiento del Quinto Informe Periódico de la República Argentina. Versión oficial.

82) Resolución de la Asamblea General de las Naciones Unidas, Consejo de Derechos Humanos, Acelerar los esfuerzos para eliminar todas las formas de violencia contra la mujer: garantizar la diligencia debida en la prevención, A/HRC/14/L.9/Rev.1, 16 de junio de 2010.

83) Resolución de la Asamblea General de las Naciones Unidas, Intensificación de los esfuerzos para eliminar todas las formas de violencia contra la mujer, A/RES/64/137, 11 de febrero de 2010 .

84) Revista Mujer/Fempress (Santiago de Chile), núm. 143, septiembre de 1993.

85) Revista La Maga, “Acoso sexual o discriminación”, pág. 48, mayo 1998.

86) Revista Veintitrés “La Madre de la Patria”, Buenos Aires, Época II, año 10, número 537, 2008, pág 3 y tapa. Biografía de María Remedios del Valle.

87) Rice, Patrick. "El rol de los organismos no gubernamentales de derechos humanos en las Naciones Unidas", Revista de Relaciones Internacionales, La Plata, IRI, Año 3 n $^{\circ}$ 4, mayo de 1993.

88) Rodriguez Saiach, Luis A. "Acoso Sexual e indemnizaciones por despido", Buenos Aires, 1993.

89) Sáenz, Patricia. “Acoso sexual, una de las manifestaciones de la violencia laboral”. La Ley, año 70, nº 82 (27-4-2006) Buenos Aires, pág.1-2.

90) Sahuquillo, María R. (2012, Octubre 9) "Un tribunal no ve acoso sexual en besos y tocamientos indeseados La Audiencia de Madrid absuelve a un jefe que daba palmadas 
en las nalgas y se rozaba con dos empleadas porque no aprecia propósito sexual, sino sentimental", Madrid-España.

91) Salvioli, Fabián Omar. (Marzo 1994). “La Conferencia de Viena de las Naciones Unidas, Esperanzas y frustraciones en materia de Derechos Humanos", Argentina. Conferencia.

92) Sardegna, Paula Costanza. (2003). "Trabajo de mujeres. Perspectiva de género. Contrato de trabajo. Normativa nacional e internacional. Jurisprudencia". Buenos Aires Argentina. Ed. La Ley S.A.E e I.

93) Serna Calvo, María del Mar. 1994. «Acoso sexual en las relaciones laborales», Revista de Relasur (Montevideo), núm. 2, págs. 33-48.

94) Serrano Alou, Sebastián. "El acoso laboral y su prueba luego de la ley 26.485". Derecho del Trabajo La Ley, año 71, no 8, Agosto 2001, pág. 1999-2009.

95) Serrano González, Alicia E. "Ley no 12.764 contra el acoso sexual en la administración pública. Nacimiento posterior a la experiencia”, Revista del Colegio de Abogados de La Plata, año XLII, nº 63, pág. 117-127.

96) Simonoff, Alejandro "La UCR y la Política Exterior. Análisis de cien años del discurso radical”, IRI, La Plata, 1997. Tesis de Maestría.

97) “Situation légale du délit de harcélement sexual”, pág. 182-191, 210-215. 1998.

98) Sistema Interamericano de Derechos Humanos: CIDH, Informe $N^{0}$ 28/07, Casos 12.496-12.498, Claudia Ivette González y Otros, Informe sobre el Fondo (México), 9 de marzo de 2007; Corte Interamericana de Derechos Humanos, Caso de González et al. ("Campo Algodonero") c. México, Sentencia de 16 de noviembre de 2009; CIDH "Acceso a la Justicia para Mujeres Víctimas de Violencia en las Américas", 20 de enero de 2007.

99) Solano, Marta Eugenia, y Badilla, Ana Elena. 1993. El acoso sexual en el empleo: ¿Qué se ha hecho hasta ahora en Costa Rica? Proyecto interdepartamental «La igualdad de las mujeres en materia de empleo», documento de trabajo núm. 9. Ginebra, OIT. 100) The Washington Post, especial para Diario Clarín, "Degradan a un general de EE.UU por escándalo Sexual-La sanción más dura contra un alto oficial”, Clarín, 18/11/1999.

101) Torres Molina, Ramón. "Los derechos humanos en la Argentina", Ed. Campana del Pueblo, Buenos Aires, marzo 1990.

102) Universidad Nacional de La Plata. Facultad de Ciencias Jurídicas y Sociales. (2012, Julio 30). “El Acoso Laboral”. Diario Argentina Investiga, Sección: Noticias. 
103) Urien, Paula. (2011, Febrero 13). “Tormento en el trabajo. El acoso sexual, más fácil de probar. Los indicios ahora cuentan en los juicios; se registran casos entre personas del mismo sexo y con agresores de menor rango que las víctimas". Diario La Nación.

104) Valenciano, Zunilda Rosa. (2005). "No a la violencia laboral”. ( $2^{\circ}$ edición, $1^{\circ}$ reimpresión). Argentina. Unión del Personal Civil de la Nación (UPCN). Tomo 2.

105) Vazquez, Gabriela Alejandra. "Aspectos Jurídicos del acoso sexual en el trabajo". Revista de Derecho Laboral, Vol 2008-2, 2008, Buenos Aires, pág. 425-451.

106) Vivanco, José Miguel. "Las organizaciones no gubernamentales de Derechos Humanos". Costa Rica, Instituto Interamericano de Derechos Humanos, Serie: Estudios de Derechos Humanos, Tomo I. 